\title{
ॠUSGS
}

science for a changing world

\section{A Multi-Metric Assessment of Environmental Contaminant Exposure and Effects in an Urbanized Reach of the Charles River near Watertown, Massachusetts}

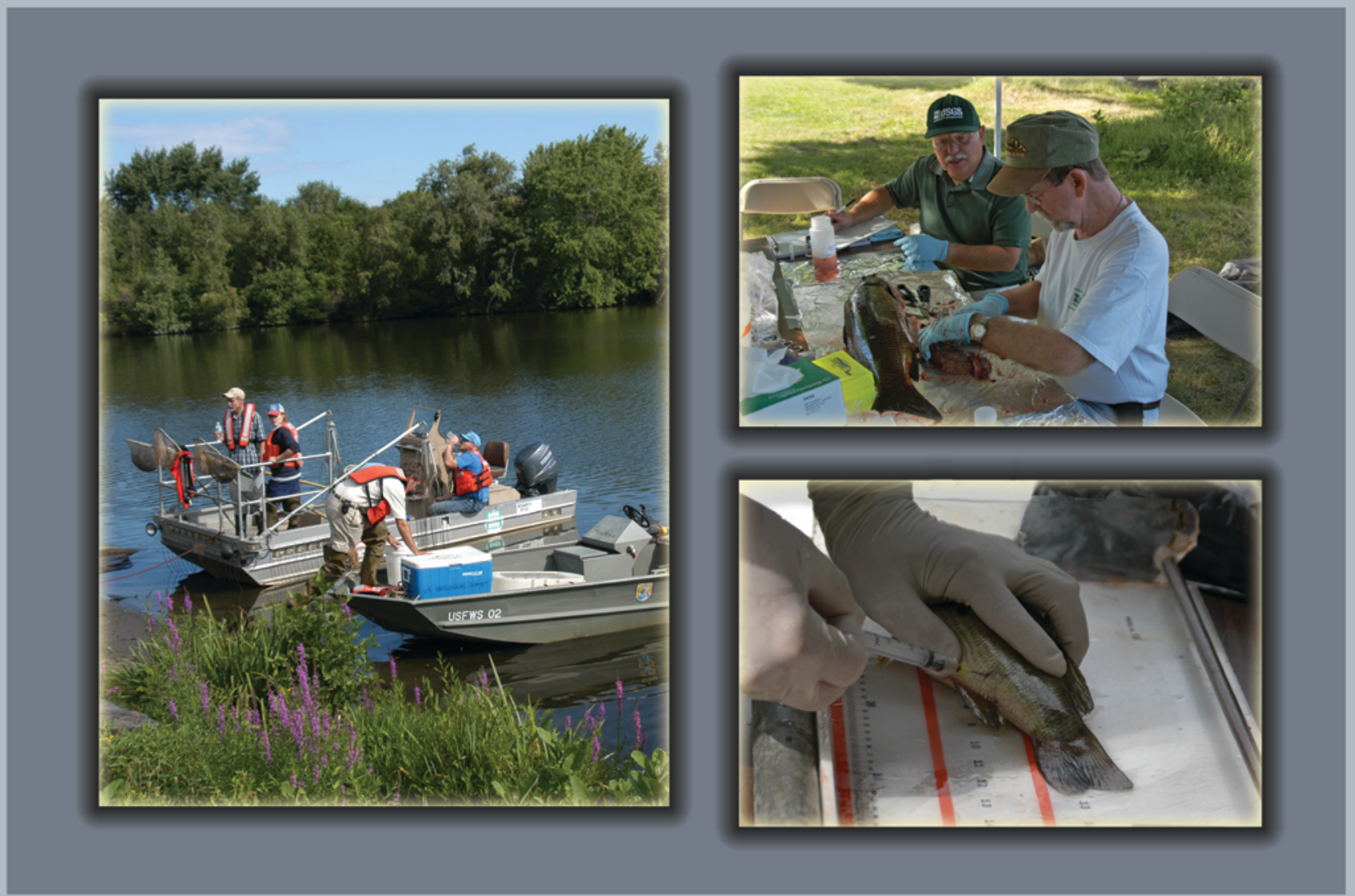

Open-File Report 2012-1195 
Cover photo credits Steven Smith and Patrick Anderson, U.S. Geological Survey. 


\section{A Multi-Metric Assessment of Environmental Contaminant Exposure and Effects in an Urbanized Reach of the Charles River near Watertown, Massachusetts}

By, Stephen B. Smith, Patrick J. Anderson, Paul C. Baumann, Lawrence R. Deweese, Steven L. Goodbred, James J. Coyle, David R. Smith

Open-File Report 2012-1195

U.S. Department of the Interior

U.S. Geological Survey 


\section{U.S. Department of the Interior \\ KEN SALAZAR, Secretary}

\section{U.S. Geological Survey \\ Marcia K. McNutt, Director}

U.S. Geological Survey, Reston, Virginia 2012

For product and ordering information:

World Wide Web: http://www.usgs.gov/pubprod

Telephone: 1-888-ASK-USGS

For more information on the USGS-the Federal source for science about the Earth,

its natural and living resources, natural hazards, and the environment:

World Wide Web: http://www.usgs.gov

Telepone: 1-888-ASK-USGS

Suggested citation: Smith, S.B., Anderson, P.J., Baumann, P.C., Deweese, L.R., Goodbred, S.L., Coyle, J.J ., and Smith, D.R., 2012, A multi-metric assessment of environmental contaminant exposure and effects in an urbanized reach of the Charles River near Watertown, Massachusetts: U.S. Geological Survey Open-File Report 2012-1195, 116 p.

Any use of trade, product, or firm names is for descriptive purposes only and does not imply endorsement by the U.S. Government.

Although this report is in the public domain, permission must be secured from the individual copyright owners to reproduce any copyrighted material contained within this report. 


\section{Contents}

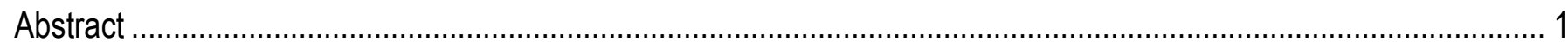

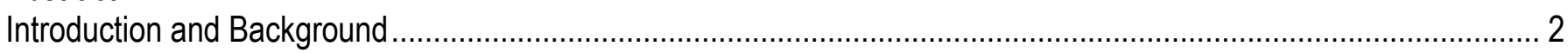

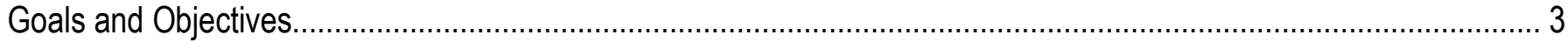

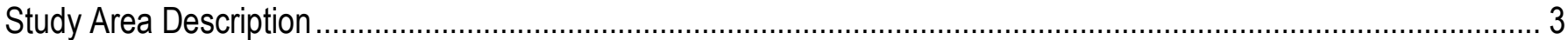

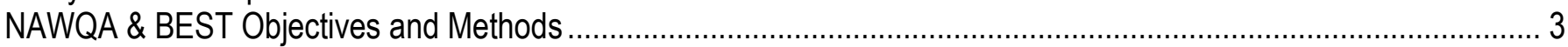

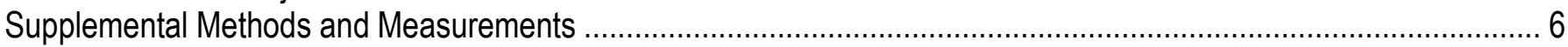

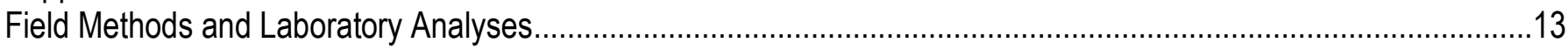

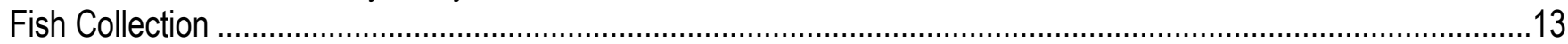

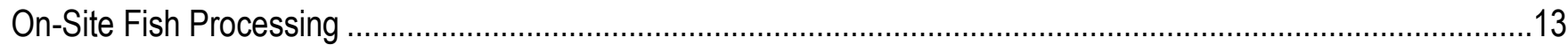

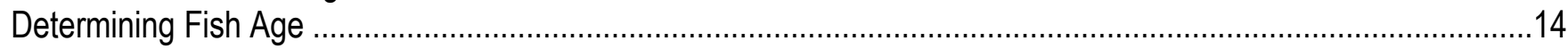

Sediment and Water Chemistry ...................................................................................................... 14

Semi-Permeable Membrane Device (SPMD) and Polar Organic Contaminant Integrated Sampler (POCIS) .......14

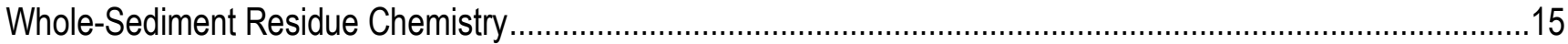

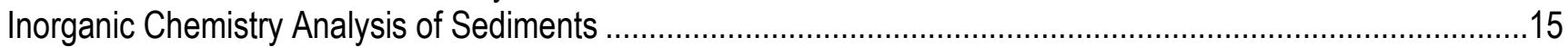

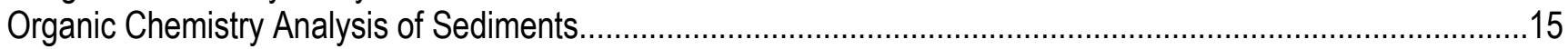

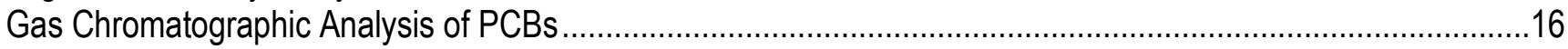

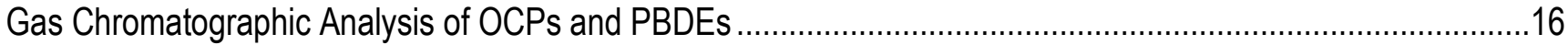

Gas chromatographic/Mass Spectrometric Analysis (GC/MS) of PAHs .....................................................17

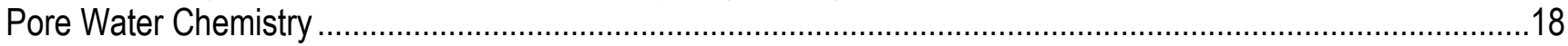

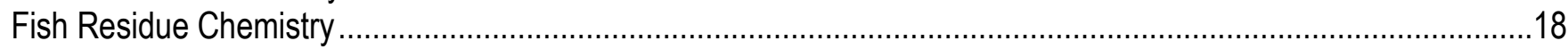

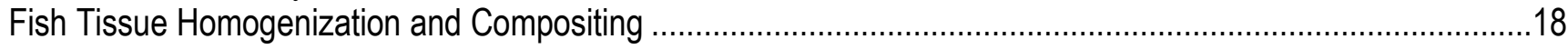

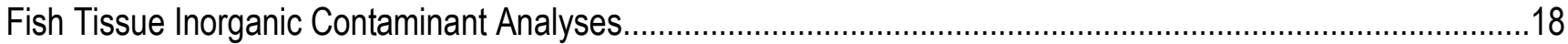

Fish Tissue Organic Contaminant Analyses (PCBs, OCPs, and Toxaphene) ..............................................18

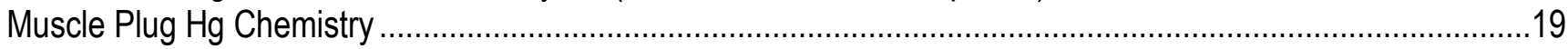

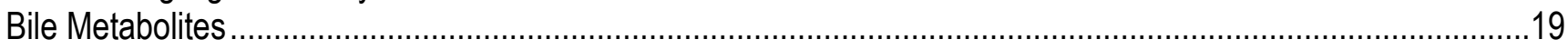

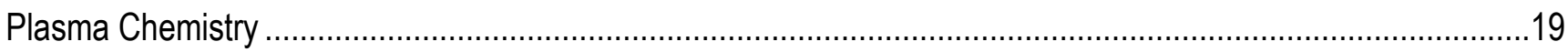

Toxicity Tests Associated with Sediment and Extracts from SPMD and POCIS Samplers ...................................20

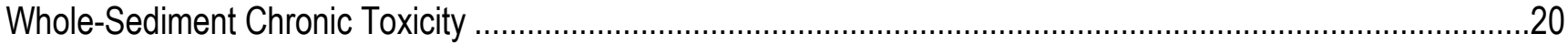

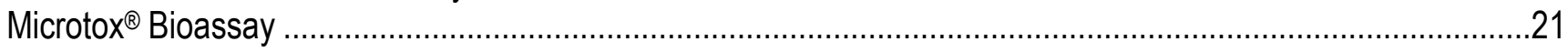

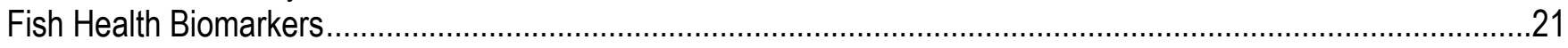

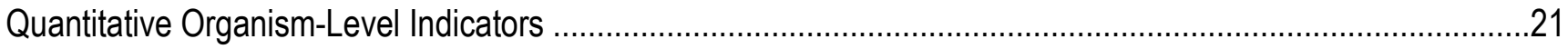

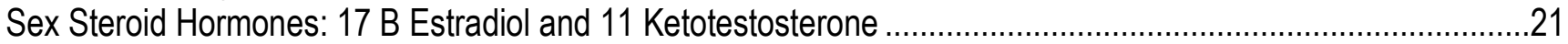

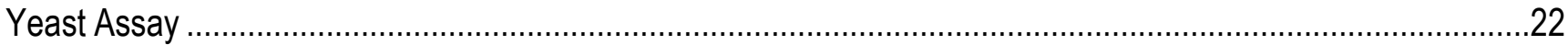

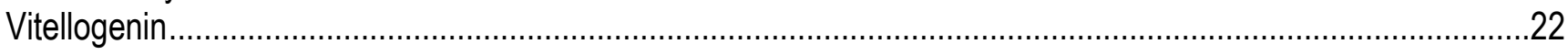

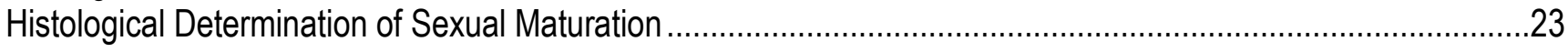

Fecundity

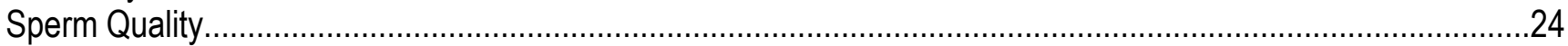

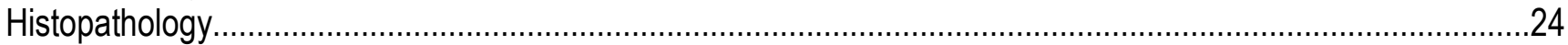

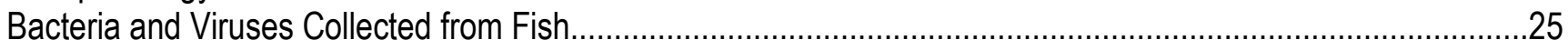

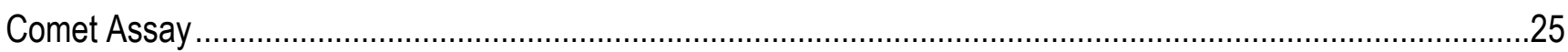

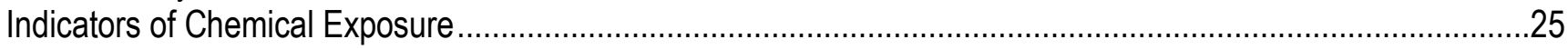

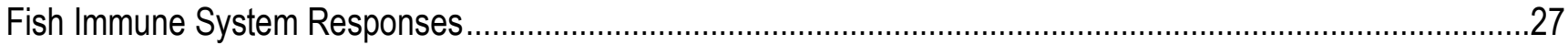

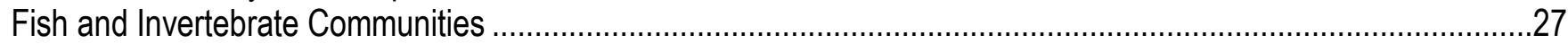

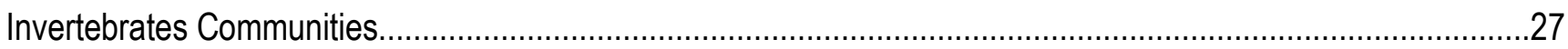

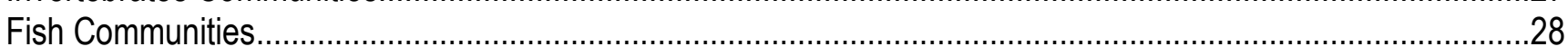

Results. 


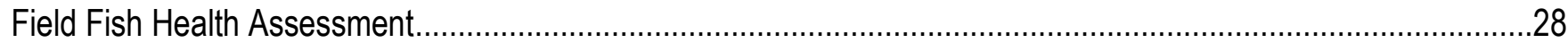

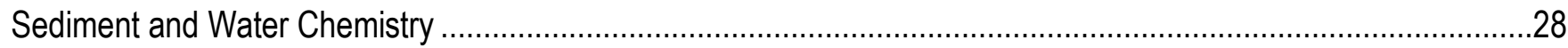

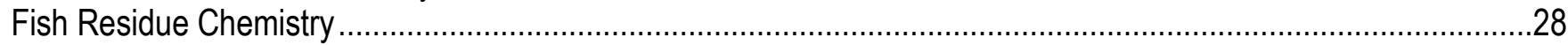

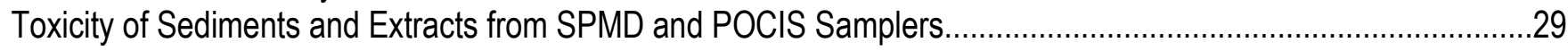

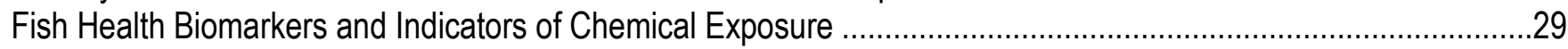

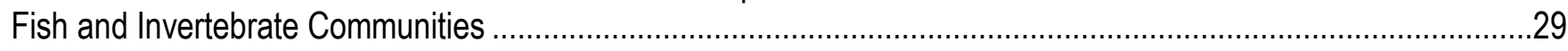

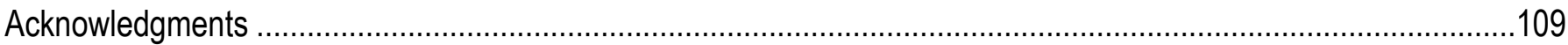

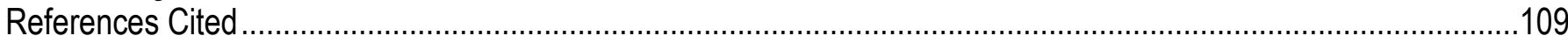

\section{Figures}

1. The sampling reach for this study is located in upper portions of the lower Charles River Watershed near

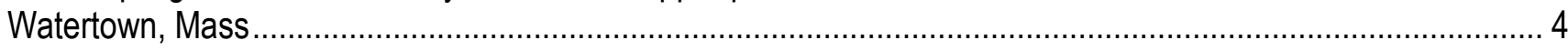

2. Semi-permeable membrane devices (SPMD) and polar organic contaminant integrated samplers (POCIS) were placed at Sites A and B........................................................................................................ 6

\section{Tables}

1. Drainages and dominant land use of the lower Charles River, Mass., from the Watertown Dam to the Brighton drainage outlet .....

2. Methods used by the Biomonitoring of Environmental Status and Trends (BEST) and National Water-Quality Assessment (NAWQA) programs used to assess contaminant exposure and effects in fish residing in the Charles River, Mass

3. Charles River sampling locations and retrieval dates for data collected by semi-permeable membrane devices (SPMD) and polar organic contaminant integrated samplers (POCIS) and collection of bed sediments and associated pore water

4. Supplementary methods and measurements used to assess ecological condition, invertebrate and fish communities, and contaminant exposure and effects in fish residing in the Charles River, Mass.

5. Gender, body weight, length, and age of fish collected from the Charles River sorted by species and gender.....

6. Location and number of fish with lesions, anomalies, and parasites observed during the field health assessment in common carp, largemouth bass, and white suckers from the Charles River (August, 2005)....... 33

7. Types of lesions and anomalies and their frequency of detection in common carp, largemouth bass, and white suckers from the Charles River (August, 2005).

8. Organosomatic indices, condition factor, and health assessment index (HAl) for common carp, largemouth bass, and white suckers collected from the Charles River (August, 2005)

9. Organochlorine pesticide (OCP) and total polychlorinated biphenyl (PCB) analyte concentrations from semi-permeable membrane devices (SPMD) collected from the Charles River after 33 days of deployment (August, 2005).

10. Polycyclic aromatic hydrocarbon (PAH) analyte concentrations from semi-permeable membrane devices (SPMDs) collected from the Charles River after 33 days of deployment (August, 2005).

11. Pesticide and hormone concentrations from polar organic chemical integrative samplers (POCIS) collected from the Charles River after 33 days of deployment (August, 2005).

12. Analytes associated with total polychlorinated biphenyls (PCBs), organochlorine pesticides (OCPs), and polybrominated diphenyl ether (PBDE) concentrations ( $\mathrm{ng} / \mathrm{g}$ dry weight) from three sediment samples collected from the Charles River (August, 2005).

13. Polycyclic Aromatic Hydrocarbon (PAH) analyte concentrations ( $\mathrm{ng} / \mathrm{g}$ dry weight) from three sediment samples collected from the Charles River (August, 2005) 
14. Measured concentrations $(\mathrm{ng} / \mathrm{mL})$ of elements in filtered sediment pore water from the Charles River (August, 2005).

15. Measured concentrations ( $\mu \mathrm{g} / \mathrm{g}$ dry weight) of total recoverable elements in Charles River sediments collected August, 2005

16. Concentration (ng/g wet weight) of total polychlorinated biphenyls (PCBs) and organochlorine pesticides (OCPs) and percent lipids in composite samples of whole fish collected from the Charles River (August, 2005)....

17. Concentrations of inorganic contaminants ( $\mu \mathrm{g} / \mathrm{g}$ dry weight) in composite samples of whole fish collected from the Charles River (August, 2005)

18. Mercury concentrations ( $\mu \mathrm{g} / \mathrm{g}$ dry weight) as determined from muscle tissue (plug) collection from largemouth bass collected from the Charles River (August, 2005)

19. Concentration (ng/g wet weight) of total polychlorinated biphenyls (PCBs) and organochlorine pesticides (OCPs) and percent lipids in individual whole white suckers (WS) collected from the Charles River (August, 2005)

20. Bile concentrations $(\mu \mathrm{g} / \mathrm{mL})$ of polycyclic aromatic hydrocarbon (PAH) metabolites from common carp, largemouth bass, and white suckers collected from the Charles River (August, 2005)

21. Concentrations of contaminants (ng/g wet weight) in plasma from white suckers (WS), common carp (CC), and largemouth bass (LMB) collected from the Charles River (August, 2005).....

22. Concentrations (ng/g wet weight) of organochlorines, polybrominated diphenyl ether (PBDE), and polychlorinated biphenyls (PCBs) in plasma from white suckers (WS), common carp (CC), and largemouth bass (LMB) collected from the Charles River (August 2005).

23. Mean survival and growth of the amphipod Hyalella azteca in 28-day exposures and of the midge Chironomus dilutus in 10-day exposures to sediment samples from the Charles River and to a control sediment.

24. Potential toxicity of extracts from semi-permeable membrane devices (SPMD) and from polar organic contaminant integrated samplers (POCIS) using the Microtox® bioassay and the yeast estrogen screen (YES) bioassay.

25. Gender, stage, sex steroid hormones, vitellogenin, and thyroid hormones in blood plasma of common carp (CC), largemouth bass (LMB), and white suckers (WS) collected from the Charles River (August, 2005) .......... 86

26. Fecundity (estimated total number of oocytes per gonad) of female common carp collected from the Charles River (August, 2005)

27. Sperm-quality metrics estimated for male common carp collected from the Charles River (August, 2005) ........ 91

28. Types of lesions and anomalies observed during histological examination and the percentage of common carp, largemouth bass, and white suckers affected....

29. Density and mean surface size of melanomacrophage centers (MMC) ${ }^{1}$ located in the liver, spleen, and renal kidney from common carp, largemouth bass, and white suckers collected from the Charles River (August, 2005).

30. Comet assay measurements taken on blood and liver cells collected from common carp (CC) and white suckers (WS) from the Charles River (August, 2005)

31. H4IIE bioassay-derived 2,3,7,8-tetrachlorodibenzo-p-dioxin equivalents (TCDD-EQ), standard deviation, limit of detection (LOD), and limit of quantitation (LOQ) of composite fish samples collected from the Charles River (August, 2005).

32. Mean hepatic ethoxyresorufin-0-deethylase (EROD) activity rate determined from liver samples collected from common carp (CC) and largemouth bass (LMB) in the Charles River (August, 2005). (pmols/min/mg, picomole per minute per milligram; SD, standard deviation; SE, standard error; CV, coefficient of variation; $L O D$, limit of detection; $L O Q$, limit of quantitation). 
33. Cytochrome P4501A enzyme activity measured as ethoxyresorufin-o-deethylase (EROD) activity in gill filament tips from white suckers (WS), common carp (CC), and largemouth bass (LMB) collected from the Charles River (August, 2005)

34. Concentration of vitamin $\mathrm{C}$ (ascorbic acid, AA) and vitamin $\mathrm{E}$ ( $\mathrm{a}$-tocopherol) as measured in liver tissue from from common carp and white suckers collected from the Charles River (August, 2005)

35. Abundance of invertebrates collected from depositional areas from the Charles River on August 25, 2005 ..... 102

36. Abundance of invertebrates collected from riffles as part of the National Water-Quality Assessment (NAWQA) protocol from the Charles River during 2002 and 2003 (NAWQA Station 01104615

37. Abundance of fish collected as part of the National Water-Quality Assessment (NAWQA) protocol from the Charles River during 2002 and 2003 (NAWQA Station \#01095220) 


\section{Conversion Factors}

Inch/Pound to SI

\begin{tabular}{|c|c|c|}
\hline Multiply & By & To obtain \\
\hline \multicolumn{3}{|c|}{ Length } \\
\hline inch (in.) & 2.54 & centimeter $(\mathrm{cm})$ \\
\hline inch (in.) & 25.4 & millimeter $(\mathrm{mm})$ \\
\hline foot $(\mathrm{ft})$ & 0.3048 & meter $(\mathrm{m})$ \\
\hline mile (mi) & 1.609 & kilometer (km) \\
\hline mile, nautical (nmi) & 1.852 & kilometer (km) \\
\hline yard (yd) & 0.9144 & meter $(\mathrm{m})$ \\
\hline \multicolumn{3}{|c|}{ Area } \\
\hline acre & 4,047 & square meter $\left(\mathrm{m}^{2}\right)$ \\
\hline acre & 0.4047 & hectare (ha) \\
\hline acre & 0.4047 & square hectometer $\left(\mathrm{hm}^{2}\right)$ \\
\hline acre & 0.004047 & square kilometer $\left(\mathrm{km}^{2}\right)$ \\
\hline square foot $\left(\mathrm{ft}^{2}\right)$ & 929.0 & square centimeter $\left(\mathrm{cm}^{2}\right)$ \\
\hline square foot $\left(\mathrm{ft}^{2}\right)$ & 0.09290 & square meter $\left(\mathrm{m}^{2}\right)$ \\
\hline square inch $\left(\mathrm{in}^{2}\right)$ & 6.452 & square centimeter $\left(\mathrm{cm}^{2}\right)$ \\
\hline section (640 acres or 1 square mile) & 259.0 & square hectometer $\left(\mathrm{hm}^{2}\right)$ \\
\hline square mile $\left(\mathrm{mi}^{2}\right)$ & 259.0 & hectare (ha) \\
\hline square mile $\left(\mathrm{mi}^{2}\right)$ & 2.590 & square kilometer $\left(\mathrm{km}^{2}\right)$ \\
\hline \multicolumn{3}{|c|}{ Volume } \\
\hline $\begin{array}{l}\text { barrel (bbl), (petroleum, } \\
1 \text { barrel=42 gal) }\end{array}$ & 0.1590 & cubic meter $\left(\mathrm{m}^{3}\right)$ \\
\hline ounce, fluid (fl. oz) & 0.02957 & liter $(\mathrm{L})$ \\
\hline $\operatorname{pint}(p t)$ & 0.4732 & liter $(\mathrm{L})$ \\
\hline quart (qt) & 0.9464 & liter (L) \\
\hline gallon (gal) & 3.785 & liter $(\mathrm{L})$ \\
\hline gallon (gal) & 0.003785 & cubic meter $\left(\mathrm{m}^{3}\right)$ \\
\hline gallon (gal) & 3.785 & cubic decimeter $\left(\mathrm{dm}^{3}\right)$ \\
\hline million gallons (Mgal) & 3,785 & cubic meter $\left(\mathrm{m}^{3}\right)$ \\
\hline cubic inch $\left(\right.$ in $\left.^{3}\right)$ & 16.39 & cubic centimeter $\left(\mathrm{cm}^{3}\right)$ \\
\hline cubic inch $\left(\mathrm{in}^{3}\right)$ & 0.01639 & cubic decimeter $\left(\mathrm{dm}^{3}\right)$ \\
\hline cubic inch $\left(\right.$ in $\left.^{3}\right)$ & 0.01639 & liter (L) \\
\hline cubic foot $\left(\mathrm{ft}^{3}\right)$ & 28.32 & cubic decimeter $\left(\mathrm{dm}^{3}\right)$ \\
\hline cubic foot $\left(\mathrm{ft}^{3}\right)$ & 0.02832 & cubic meter $\left(\mathrm{m}^{3}\right)$ \\
\hline cubic yard $\left(\mathrm{yd}^{3}\right)$ & 0.7646 & cubic meter $\left(\mathrm{m}^{3}\right)$ \\
\hline
\end{tabular}




\begin{tabular}{|c|c|c|}
\hline cubic mile $\left(\mathrm{mi}^{3}\right)$ & 4.168 & cubic kilometer $\left(\mathrm{km}^{3}\right)$ \\
\hline acre-foot (acre-ft) & 1,233 & cubic meter $\left(\mathrm{m}^{3}\right)$ \\
\hline acre-foot (acre-ft) & 0.001233 & cubic hectometer $\left(\mathrm{hm}^{3}\right)$ \\
\hline \multicolumn{3}{|c|}{ Mass } \\
\hline ounce, avoirdupois (oz) & 28.35 & gram (g) \\
\hline pound, avoirdupois (lb) & 0.4536 & kilogram (kg) \\
\hline ton, short $(2,000 \mathrm{lb})$ & 0.9072 & megagram (Mg) \\
\hline ton, long $(2,240 \mathrm{lb})$ & 1.016 & megagram $(\mathrm{Mg})$ \\
\hline ton per day (ton/d) & 0.9072 & metric ton per day \\
\hline ton per day (ton/d) & 0.9072 & megagram per day $(\mathrm{Mg} / \mathrm{d})$ \\
\hline $\begin{array}{l}\text { ton per day per square mile } \\
{\left[(\operatorname{ton} / \mathrm{d}) / \mathrm{mi}^{2}\right]}\end{array}$ & 0.3503 & $\begin{array}{l}\text { megagram per day per square } \\
\text { kilometer }\left[(\mathrm{Mg} / \mathrm{d}) / \mathrm{km}^{2}\right]\end{array}$ \\
\hline ton per year (ton/yr) & 0.9072 & megagram per year $(\mathrm{Mg} / \mathrm{yr})$ \\
\hline ton per year (ton/yr) & 0.9072 & metric ton per year \\
\hline
\end{tabular}

Temperature in degrees Celsius $\left({ }^{\circ} \mathrm{C}\right)$ may be converted to degrees Fahrenheit $\left({ }^{\circ} \mathrm{F}\right)$ as follows:

${ }^{\circ} \mathrm{F}=\left(1.8 \times^{\circ} \mathrm{C}\right)+32$

Specific conductance is given in microsiemens per centimeter at 25 degrees Celsius $\left(\mu \mathrm{S} / \mathrm{cm}\right.$ at $\left.25^{\circ} \mathrm{C}\right)$.

Concentrations of chemical constituents in water are given either in milligrams per liter (mg/L) or micrograms per liter $(\mu \mathrm{g} / \mathrm{L})$. 


\section{Acronyms Used in This Document}

AHTN Tonalide, a polycyclic musk used in fragrances (6-Acetyl-1,1,2,4,4,7-Hexamethyltetraline, and related

AMTL

ASE

AVS

BDE

BEST

BHIA

BKD

BRD

CBP

CC

CERC

CF

CPRG

DAD

DDE

DMA

DMSO

EC

ECD

ECNICl

ELISA

EPA

EQ

EROD

FWS

GC

GC-MSD

GS/MS

GSI

HAI

HC

HHCB

HPLC

HPSEC

HSI

ICC

IIS

IPA

KT

LMB

LOD

LOI

LOQ isomers)

Army Materials Technology Laboratory

Accelerated solvent extractor

Acid volatile sulfide

Brominated diphenyl ether

Biomonitoring of Environmental Status and Trends project

Brain heart infusion agar

Bacterial kidney disease

Biological Resources Discipline (of the U.S. Geological Survey)

Contaminant Biology Program

Common carp

Columbia Environmental Research Center

Condition factor

Chlorophenol red- $\beta$-D-galactopyranoside

Diode array detector (with high-performance liquid chromatography; see HPLC below)

Dichlorodiphenyldichloroethylene

Direct mercury analysis

Dimethylsulfoxide

Effect concentration

Electron-capture detection

Electron-capture negative ion chemical ionization

Enzyme-linked immunosorbent assay

Environmental Protection Agency

Equivalents

Ethoxyresorufin-0-deethylase

U.S. Fish and Wildlife Service

Gas chromatograph

Gas chromatography with mass selective detector

Gas chromatography/mass spectroscopy

Gonadosomatic index

Health assessment index

HEPES-Cortland buffer

Galoxolide, a polycyclic musk used in fragrances $(1,3,4,6,7,8$-hexahydro-4,6,6,7,8,8-

hexamethylcyclopenta-y-2-benzopyran and related isomers)

High-performance liquid chromatograph with diode array detector

High-pressure size-exclusion chromatography

Hepatosomatic index

Immunocytochemistry

Instrumental internal standards

Isopropanol

Ketotestosterone

Largemouth bass

Limit of detection

Loss on ignition

Limit of quantitation 


$\begin{array}{ll}\text { MDL } & \text { Method detection limit } \\ \text { MMC } & \text { Melano-macrophage centers } \\ \text { MQL } & \text { Method quantitation limit } \\ \text { NAWQA } & \text { National Water-Quality Assessment } \\ \text { NCI } & \text { Negative charge ionization } \\ \text { NWQL } & \text { National Water Quality Laboratory } \\ \text { OCP } & \text { Organochlorine pesticide } \\ \text { PAH } & \text { Polycyclic aromatic hydrocarbons } \\ \text { PBDE } & \text { Polybrominated diphenyl ether } \\ \text { PCB } & \text { Polychlorinated biphenyl } \\ \text { PHH } & \text { Planar halogenated hydrocarbons } \\ \text { POCIS } & \text { Polar organic contaminant integrated sampler } \\ \text { PSI } & \text { Pounds per square inch } \\ \text { RIA } & \text { Radioimmunoassay } \\ \text { SEM } & \text { Simultaneously extractable metals } \\ \text { SPMD } & \text { Semi-permeable membrane device } \\ \text { SSI } & \text { Splenosomatic index } \\ \text { TBST } & \text { Tris-buffered saline (containing 0.5 percent Tween) } \\ \text { TCDD-EQ } & \text { 2,3,7,8-tetrachlorodibenzo-p-dioxin equivalents } \\ \text { TU } & \text { Toxic units } \\ \text { USGS } & \text { U.S. Geological Survey } \\ \text { WRD } & \text { Water Resources Discipline } \\ \text { WS } & \text { White sucker } \\ \text { YES } & \text { Yeast estrogen screen } \\ & \end{array}$




\title{
A Multi-Metric Assessment of Environmental Contaminant Exposure and Effects in an Urbanized Reach of the Charles River near Watertown, Massachusetts
}

By Stephen B. Smith, Patrick J. Anderson, Paul C. Baumann, Lawrence R. Deweese, Steven L. Goodbred, James J. Coyle, David R. Smith1

\begin{abstract}
The Charles River Project provided an opportunity to simultaneously deploy a combination of biomonitoring techniques routinely used by the U.S. Geological Survey National Water-Quality Assessment Program, the Biomonitoring of Environmental Status and Trends Project, and the Contaminant Biology Program at an urban site suspected to be contaminated with polycyclic aromatic hydrocarbons. In addition to these standardized methods, additional techniques were used to further elucidate contaminant exposure and potential impacts of exposure on biota. The purpose of the study was to generate a comprehensive, multi-metric data set to support assessment of contaminant exposure and effects at the site. Furthermore, the data set could be assessed to determine the relative performance of the standardized method suites typically used by the National Water-Quality Assessment Program and the Biomonitoring of Environmental Status and Trends Project, as well as the additional biomonitoring methods used in the study to demonstrate ecological effects of contaminant exposure. The Contaminant Effects Workgroup, an advisory committee of the U.S. Geological Survey/Contaminant Biology Program, identified polycyclic aromatic hydrocarbons as the contaminant class of greatest concern in urban streams of all sizes. The reach of the Charles River near Watertown, Massachusetts, was selected as the site for this study based on the suspected presence of polycyclic aromatic hydrocarbon contamination and the presence of common carp (Cyprinus carpio), largemouth bass (Micropterus salmoides), and white sucker (Catostomus commersoni). All of these fish have extensive contaminant-exposure profiles related to polycyclic aromatic hydrocarbons and other environmental contaminants. This project represented a collaboration of universities, Department of the Interior bureaus including former components of the USGS
\end{abstract}

\footnotetext{
${ }^{1}$ Stephen B. Smith, U.S. Geological Survey, Biological Resources Dicipline, Reston, Va. (retired) Patrick J. Anderson,U.S. Geological Survey, Fort Collins Science Center, Fort Collins, Colo. Paul C. Baumann, U.S. Geological Survey, Leetown Science Center, Ohio State University, Columbus, Ohio (retired)

Lawrence R. DeWeese, U.S. Geological Survey, Biological Resources Discipline, Denver, Colo. (retired) Steven L. Goodbred, U.S. Geological Survey, Biologcal Resources Discipline, Sacramento, Calif. (retired) James J. Coyle, U.S. Geological Survey, Fort Collins Science Center, Fort Collins, Colo. (retired) David R. Smith, U.S. Geolocal Survey, Leetown Science Center, Leetown, W. Va.
} 
(Biological Resources Discipline and Water Resources Discipline Science Centers, the Contaminant Biology Program, and the Status and Trends of Biological Resources Program), and the U.S. Fish and Wildlife Service. Samples for analyzing water chemistry, sediment chemistry and toxicity, fish community structure, tissue chemistry, and fish (20 carp, 20 bass, and 40 white sucker) and invertebrate pathology were collected in late August, 2005. This report provides results from the analyses of fish pathology, biomarkers of exposure and effects (reproductive, carcinogenic, genotoxic, and immunologic), sediment chemistry, toxicity, and fish and invertebrate community structure.

\section{Introduction and Background}

Anthropogenic sources of pollution are recognized as a global problem that contributes to the degradation of ecosystem quality, loss of numerous plant and animal species, and adverse human health effects. Freshwater ecosystems are the ultimate sink for many anthropogenic chemicals that potentially affect aquatic communities and the terrestrial species that depend on them (Gross and others, 2003; Hoffman and others, 2003; Schmitt, Zajicek and others, 1999). There are multiple sources of these environmental contaminants with both point and non-point inputs from agriculture, industry, and residences. Increasingly, emerging contaminants (for example, pharmaceuticals including antibiotics, psychotropic medications, human reproductive modulators, pesticides, and personal care products) are suspected of contributing to adverse ecological effects. Changing demographics of the U.S. population have resulted in rapid urbanization of many areas with water resources being used for multiple purposes. For example, treated wastewater increasingly represents a significant source of riparian recharge water used for recreation, consumption, and maintaining viable ecosystems (Alvarez and others, 2006).

This study provided an opportunity to simultaneously collect data using two method suites used by two operational aquatic monitoring and assessment programs of the U.S. Geological Survey (USGS) along with additional selected measurements of exposure and effect. The deployment of these techniques was conducted at an urban site presumably impacted by polyaromatic hydrocarbons (PAHs). The two method suites applied at the site were derived from the USGS National WaterQuality Assessment (NAWQA) Program and the Biomonitoring of Environmental Status and Trends (BEST) Project of the former Biological Resources Discipline (BRD). In addition to these method suites, a set of additional assessment techniques was applied to document contaminant exposure or effects at the site. The additional techniques were selected based on best professional judgment relative to the anticipated contaminant profile of the selected site. Aside from the technical value of this comparative study, it also provided comparative data which could be used to address USGS programmatic recommendations to assess the compatibility of the method suites and minimize redundancy and maximize integration between two ongoing aquatic monitoring and assessment efforts within the agency.

The upper reach of the lower Charles River near Watertown, Mass., was selected as the study site based on documentation of past PAH contamination and the presence of common carp (Cyprinus carpio), largemouth bass (Micropterus salmoides), and white sucker (Catostomus commersoni), which have extensive contaminant exposure profiles related to PAHs and other contaminants. This reach is also considered "impaired" by state regulators because of contaminants contributed upstream by 18 combined sewer overflows serving heavily urbanized areas. Acute sediment toxicity and bioaccumulation of organic contaminants in fish from the Lower Charles River also have been reported (Friorentino and others, 2000). 
This project (hereafter the Charles River Project) addressed recommendations of an internal USGS review, which strongly encouraged additional interaction between USGS programs to monitor fish health (Contaminant Biology Program, 2002).

\section{Goals and Objectives}

River ecosystems are influenced by multiple chemical (that is, contaminants), physical (that is, habitat alteration), and biological (that is, exotic species) stressors. Understanding the relative importance of these various stressors is fundamental for effective resource management.

Unfortunately, inferences about the relative importance of these stressors often are complicated due to spatial and temporal data gaps. Existing data gaps can be alleviated by the application of appropriate ecotoxicological indicators that demonstrate contaminant effects.

The objectives of the Charles River Project included (1) deploying the operational BEST and NAWQA trends site bioassessment methods plus additional techniques capable of documenting PAH exposure and effects; (2) assessing toxicological, chemical, biological, and physical measurements in relation to sources and exposure pathways; and (3) generating an expanded data set to document exposure and effects at the site.

\section{Study Area Description}

The Charles River is a small river fed by numerous smaller brooks and streams and by several major aquifers. The Charles River meanders for 129 kilometers $(\mathrm{km})$ (starting at Echo Lake in Hopkinton, Mass.) to the Boston Harbor (fig. 1). It is often considered one of the most densely populated river basins in New England (Weiskel and others, 2005). Most of the Charles River watershed includes high-density residential and commercial developments (table 1).

Sampling locations were based on their proximity to known pollutant sources and urban development. Near the upper end of the sampling reach and just downstream of the Watertown dam is Laundry Brook, which drains areas of high- and medium-density housing with high percentages of impervious surfaces (roads, parking lots, and buildings). The Army Materials Technology Laboratory (AMTL) Superfund site is located near the lower end of the sampling reach (near site 3 in fig. 2).

Established in 1816, the original 47-acre AMTL facility was used for the storage, cleaning, repair, and issuance of small arms. From the mid-1800s until after World War II, the AMTL continued to expand, ultimately encompassing 131 acres and 53 buildings and structures and employing over 10,000 workers. Arms Manufacturing continued until an operational phase-down was initiated in 1967. A nuclear research reactor was constructed at the site to investigate molecular and atomic structure and operated until it was decommissioned in 1992 and removed in 1994. The AMTL was officially closed in 1995. Contaminants of concern on-site included polychlorinated biphenyls (PCBs), PAHs, metals, semi-volatiles and volatile organics, and pesticides (U.S. Environmental Protection Agency, 2001).

\section{NAWQA \& BEST Objectives and Methods}

The objective for the Status and Trends component of the NAWQA program is to provide an assessment of the ecological condition of the sampled reach. Existing protocols are used to sample biological communities and describe basic reach- and transect-level habitat (Moulton and others, 2002; Fitzpatrick and others, 1998).

The objective of the BEST Program large river fish-health assessments was to document the presence of contaminants in fish tissue and to measure contaminant-related biological effects in fish inhabiting selected reaches. This information can identify reaches where contaminant threats to 


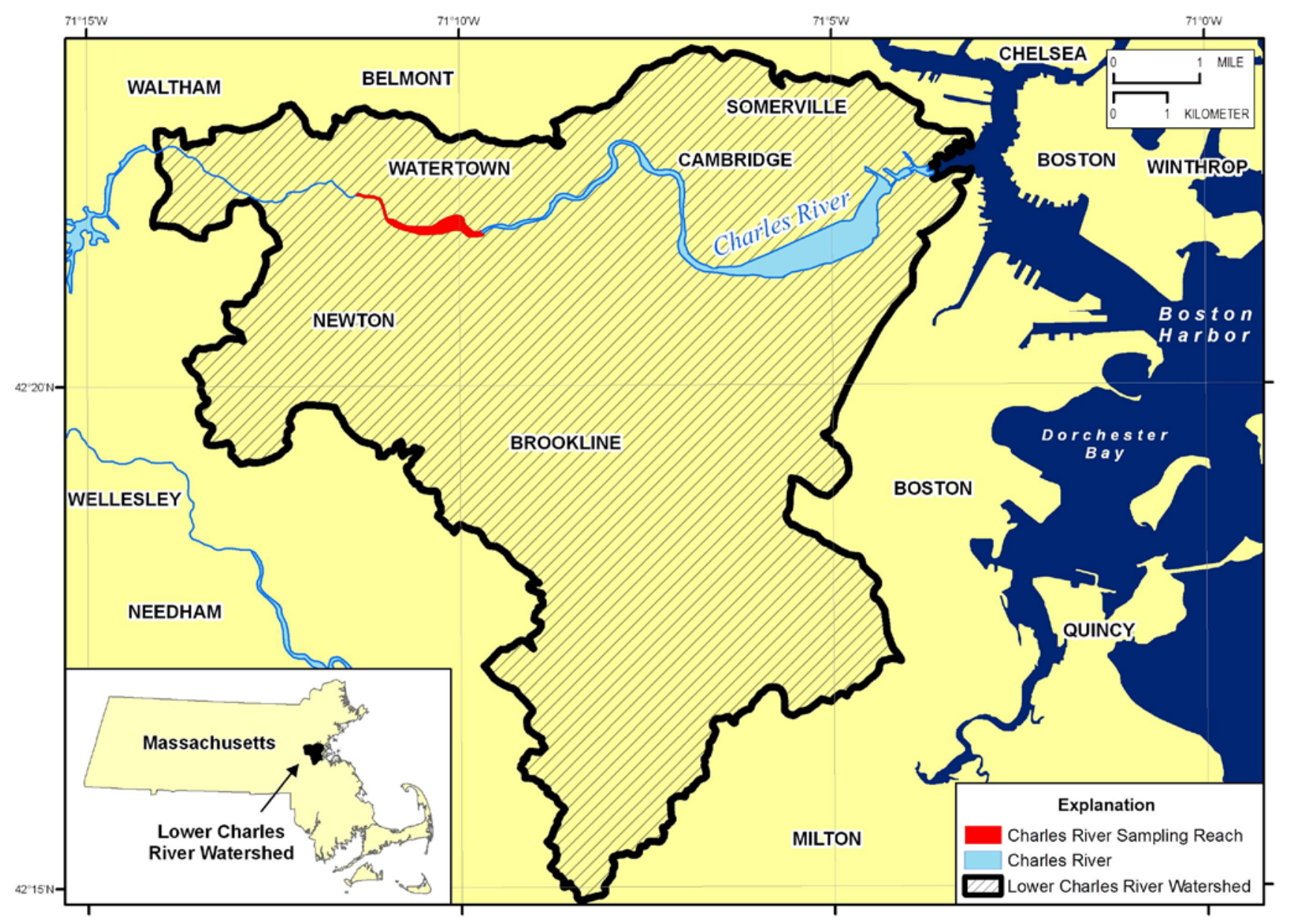

Figure 1. The sampling reach for this study is located in upper portions of the lower Charles River Watershed near Watertown, Mass. 
Table 1. Drainages and dominant land use of the lower Charles River, Mass., from the Watertown Dam to the Brighton drainage outlet. Table adapted from Weiskel and others (2005).

\begin{tabular}{|c|c|c|}
\hline Drainage & Drainage area (acres) & Dominant land uses \\
\hline Laundry Brook & 3,038 & $\begin{array}{l}\text { High-density, single-family residential; medium-density, single- } \\
\text { family residential; forested }\end{array}$ \\
\hline Watertown West local drainage & 153 & $\begin{array}{l}\text { High-density, single-family residential; urban open space; } \\
\text { commercial }\end{array}$ \\
\hline Watertown Square drainage & 560 & High-density, single-family residential; urban open space \\
\hline Newton West local drainage & 71 & High-density, single-family residential; commercial \\
\hline Hyde Brook & 439 & High-density, single-family residential; urban open space \\
\hline Newton East local drainage & 58 & $\begin{array}{l}\text { High-density, single-family residential; transportation; spectator or } \\
\text { participant recreation }\end{array}$ \\
\hline Watertown Central local drainage & 205 & High-density, single-family residential; industrial \\
\hline Watertown East local drainage & 97 & Transportation; spectator or participant recreation \\
\hline Brighton local drainage & 190 & High-density, single-family residential; transportation; commercial \\
\hline
\end{tabular}




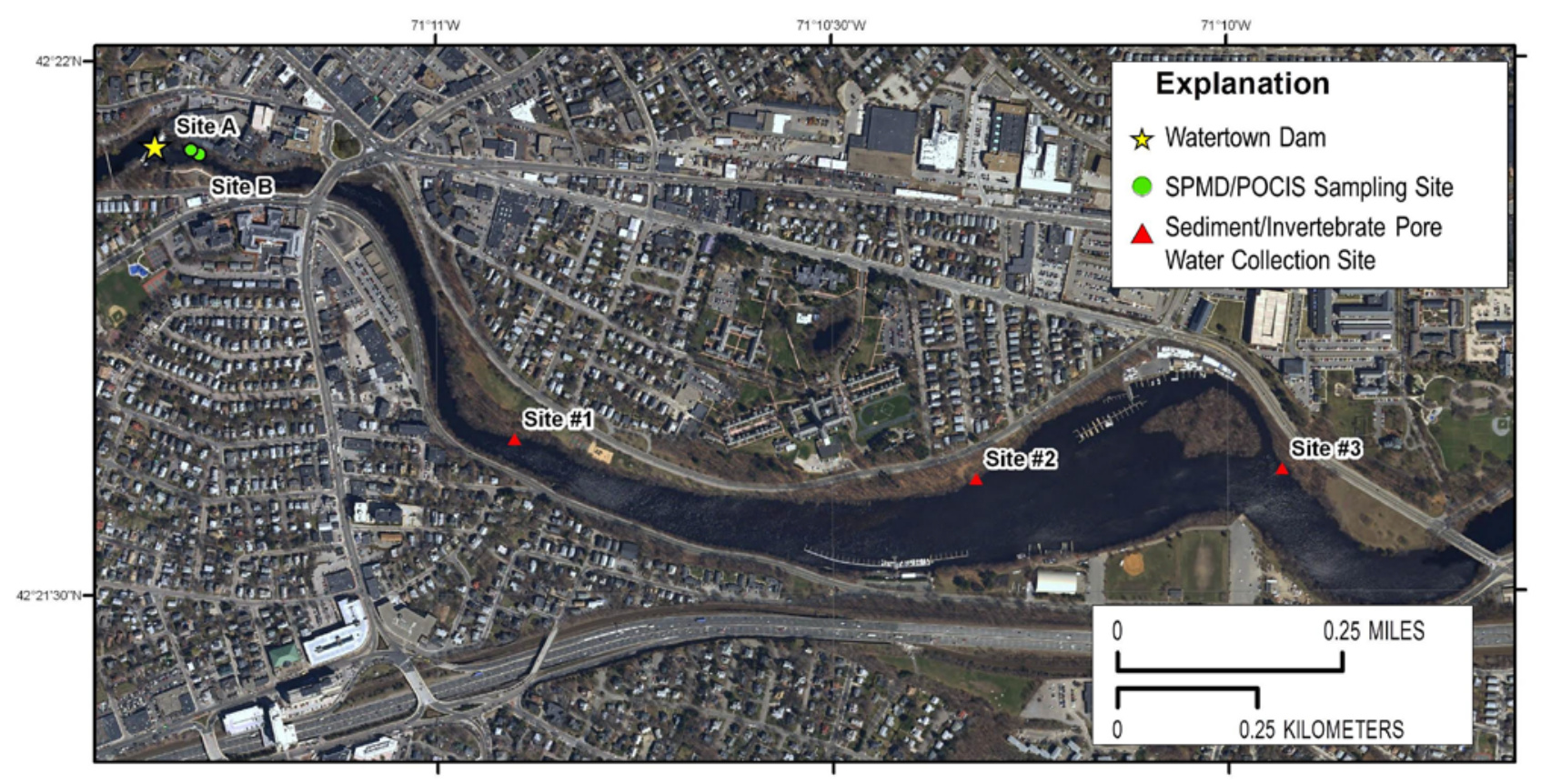

Figure 2. Semi-permeable membrane devices (SPMD) and polar organic contaminant integrated samplers (POCIS) were placed at Sites A and B. Sediments, pore water, and invertebrates were obtained at sampling sites 1, 2, and 3. Fish were sampled along the entire reach (Charles River, Watertown, Mass.).

biological resources warrant further investigation. The information can also provide evidence regarding the effectiveness of guidelines set for the protection of species and their habitats. Results from the large river fish health assessments are integrated with information from other sources to better understand potential associations between contaminant exposures and impacts to the nation's biological resources and habitat quality (National Research Council, 1995, National Research Council, 2002). The methods used in the fish health assessments include 20 individuals with at least ten individuals of each sex from both a benthic and a piscivorous species, age, histopathology, somatic indices, biomarkers of reproductive effects (for example, plasma hormones), biomarkers of biochemical response to contaminant exposure (for example, ethoxyresorufin O-deethylase [EROD] activity, H4IIE rat hepatoma assay), and composite fish residue analysis for persistent and bio-accumulative organic and inorganic contaminants (Schmitt, Blazer and others, 1999; Schmitt and Dethloff, 2000). Established NAWQA and BEST methods used in this study are provided in table 2.

\section{Supplemental Methods and Measurements}

In addition to the established NAWQA and BEST methods, additional supplemental methods were used in the Charles River study to augment the assessment of ecological conditions in the sampled reach. Water chemistry was supplemented with semi-permeable membrane devices (SPMD) and polar organic contaminant integrated samplers (POCIS) and the collection and analyses of bed sediments and associated pore water are provided in table 3. Supplementary methods and measurements used to assess ecological condition, invertebrate and fish communities, and contaminant exposure and effects in fish that are not currently used by NAWQA or BEST are provided in table 4. 
Table 2. Methods used by the Biomonitoring of Environmental Status and Trends (BEST) and National Water-Quality Assessment (NAWQA) programs used to assess contaminant exposure and effects in fish residing in the Charles River, Mass.

\begin{tabular}{|c|c|c|c|}
\hline Method & Description & Metric & Reference \\
\hline \multicolumn{4}{|l|}{ BEST Program } \\
\hline Gonadal stage & Evaluation of gonad development & $\begin{array}{l}\text { Histological examination of testis or } \\
\text { ovary }\end{array}$ & $\begin{array}{l}\text { Goodbred and others (1997), } \\
\text { Schmitt, Blazer and others (1999) }\end{array}$ \\
\hline $\begin{array}{l}\text { Fish tissue chemical residue } \\
\text { analyses }\end{array}$ & $\begin{array}{l}\text { Measurements of a suite of inorganic } \\
\text { and organic chemicals in fish tissue }\end{array}$ & $\begin{array}{l}\text { Concentrations of OCPs, total PCBs, } \\
\text { elements and priority metals in whole } \\
\text { body composites based on species and } \\
\text { gender }\end{array}$ & $\begin{array}{l}\text { Orazio and others (2006), May and } \\
\text { others (2006) }\end{array}$ \\
\hline EROD activity & $\begin{array}{l}\text { Enzyme induction by planar } \\
\text { hydrocarbons }\end{array}$ & $\begin{array}{l}\text { PCBs; chlorinated dioxins and furans; } \\
\text { PAHs as measured from liver tissue }\end{array}$ & $\begin{array}{l}\text { Pohl and Fouts (1980); Kennedy } \\
\text { and Jones (1994); Whyte and } \\
\text { others (2000) }\end{array}$ \\
\hline $\begin{array}{l}\text { Necropsy-based fish health } \\
\text { assessment }\end{array}$ & $\begin{array}{l}\text { Assessment of anomalies as they } \\
\text { relate to overall health }\end{array}$ & $\begin{array}{l}\text { Visual assessment of external and } \\
\text { internal anomalies on skin, fins, gills, } \\
\text { peritoneal cavity, and select organs and } \\
\text { overall condition factor }\end{array}$ & $\begin{array}{l}\text { Adams and others (1993); Adams } \\
\text { (1990); Smith, Donahue and others } \\
\text { (2002) }\end{array}$ \\
\hline Somatic indices & $\begin{array}{l}\text { Indication of overall health and } \\
\text { growth }\end{array}$ & SSI, HSI, GSI & Grady and others (1992) \\
\hline Histopathology & Indication of chemical exposure & $\begin{array}{l}\text { Microscopic examination for the } \\
\text { presence of lesions and anomalies }\end{array}$ & $\begin{array}{l}\text { Hinton and others (1992); Hinton } \\
\text { (1993); Goodbred and others } \\
\text { (1997) }\end{array}$ \\
\hline Macrophage aggregate analyses & $\begin{array}{l}\text { Cellular immune response to multiple } \\
\text { contaminants including PAHs and } \\
\text { metals }\end{array}$ & $\begin{array}{l}\text { Density and mean surface size of } \\
\text { melanomacrophage cell centers located } \\
\text { in the liver, spleen, and renal kidney }\end{array}$ & Blazer and others $(1994,1997)$ \\
\hline Vitellogenin & $\begin{array}{l}\text { A protein precursor of egg yolk, } \\
\text { normally synthesized in the liver of } \\
\text { female fish. Elevation in male fish } \\
\text { indicates exposure to endocrine- } \\
\text { modulating substances }\end{array}$ & $\begin{array}{l}\text { Concentration of vitellogenin in plasma } \\
\text { (male and female) }\end{array}$ & Denslow and others (1999) \\
\hline
\end{tabular}


Table 2. Methods used by the Biomonitoring of Environmental Status and Trends (BEST) and National Water-Quality Assessment (NAWQA) programs used to assess contaminant exposure and effects in fish residing in the Charles River, Mass. - Continued

\begin{tabular}{cll}
\hline \multicolumn{1}{c}{ Method } & \multicolumn{1}{c}{ Description } & Metric \\
\hline NAWQA Program & $\begin{array}{l}\text { Measurement of a suite of water } \\
\text { quality parameters and select } \\
\text { nutrients and organic and inorganic } \\
\text { chemicals }\end{array}$ & Analyte dependent \\
\hline Water chemistry & $\begin{array}{l}\text { Measurement of fish communities } \\
\text { associated with riffle habitats }\end{array}$ & $\begin{array}{l}\text { Abundance and number of species } \\
\text { collected associated with riffle } \\
\text { habitats }\end{array}$ \\
Fish communities & $\begin{array}{l}\text { Measurement of invertebrate species } \\
\text { collected in riffle areas of defined } \\
\text { reaches }\end{array}$ & $\begin{array}{l}\text { Abundance and number of species } \\
\text { collected }\end{array}$ \\
\hline
\end{tabular}

(EROD, ethoxyresorufin O-deethylase; GSI, mass of gonad; HSI, mass of liver; OCP, organochlorine pesticides; PCB, polychlorinated biphenyls; PAH, polycyclic aromatic hydrocarbons; SSI, mass of spleen) 
Table 3. Charles River sampling locations and retrieval dates for data collected by semi-permeable membrane devices (SPMD) and polar organic contaminant integrated samplers (POCIS) and collection of bed sediments and associated pore water.

\begin{tabular}{|c|c|c|c|c|c|c|}
\hline Site & Sample & Collection date & $\begin{array}{l}\text { Deployment duration } \\
\text { (days) }\end{array}$ & $\begin{array}{l}\text { Latitude } \\
\qquad(\mathrm{N})\end{array}$ & $\begin{array}{l}\text { Longitude } \\
\text { (W) }\end{array}$ & $\begin{array}{l}\text { Depth } \\
\text { (meters) }\end{array}$ \\
\hline \multicolumn{7}{|c|}{ SPMD/POCIS } \\
\hline Site A & SPMD A & $08 / 22 / 2005$ & 33 & $42: 36: 373$ & 71:18:758 & 2.4 \\
\hline Site B & SPMD B & $08 / 22 / 2005$ & 33 & $42: 36: 481$ & 71:18:685 & 2.4 \\
\hline Site A & POCIS A & $08 / 22 / 2005$ & 33 & $42: 36: 373$ & 71:18:758 & 2.4 \\
\hline Site B & POCIS B & $08 / 22 / 2005$ & 33 & $42: 36: 481$ & $71: 18: 685$ & 2.4 \\
\hline \multicolumn{7}{|c|}{ Bed Sediment } \\
\hline Site 1 & sample $1(a, b, c)$ & $08 / 25 / 2005$ & not applicable & $42: 36: 069$ & 71.18 .168 & 0.8 \\
\hline Site 2 & sample 2 & $08 / 25 / 2005$ & not applicable & $42: 35: 997$ & 71:17:196 & 0.9 \\
\hline Site 3 & sample 3 & $08 / 25 / 2005$ & not applicable & $42: 36: 007$ & $71: 16: 534$ & 0.9 \\
\hline
\end{tabular}


Table 4. Supplementary methods and measurements used to assess ecological condition, invertebrate and fish communities, and contaminant exposure and effects in fish residing in the Charles River, Mass. Acronyms used in table are footnoted below.

\begin{tabular}{|c|c|c|c|}
\hline Method & Description & Metric & Reference \\
\hline \multicolumn{4}{|l|}{ Fish Health } \\
\hline Sperm quality & $\begin{array}{l}\text { Sperm quality assessment } \\
\text { (reproductive health) }\end{array}$ & $\begin{array}{l}\text { Sperm motility, activation, movement, } \\
\text { and concentration collected from } \\
\text { common carp }\end{array}$ & $\begin{array}{l}\text { Patino and others (2003), Kime } \\
\text { and Nash (1999) }\end{array}$ \\
\hline Fecundity & $\begin{array}{l}\text { Egg quality and quantity } \\
\text { (reproductive health) }\end{array}$ & $\begin{array}{l}\text { Examination and measurements of eggs } \\
\text { collected from ovaries of common carp }\end{array}$ & Patino and others (2003) \\
\hline Comet assay (fish blood / liver) & $\begin{array}{l}\text { DNA integrity as an indicator of } \\
\text { contaminant exposure }\end{array}$ & $\begin{array}{l}\text { Examination and measurements of } \\
\text { genetic damage of blood and liver cells }\end{array}$ & Meier and others (2001) \\
\hline Vitamins C \& E (fish liver) & $\begin{array}{l}\text { Indicator of reproductive and overall } \\
\text { health }\end{array}$ & $\begin{array}{l}\text { Concentrations of vitamins } \mathrm{C} \text { (ascorbic } \\
\text { acid) and } \mathrm{E}(\alpha \text {-tocopherol) in liver } \\
\text { tissue as an indicator for reproductive } \\
\text { function }\end{array}$ & $\begin{array}{l}\text { Dabrowski and Hinterleitner } \\
\text { (1989) }\end{array}$ \\
\hline Thyroid hormones & $\begin{array}{l}\text { Indication of growth and metabolic } \\
\text { function }\end{array}$ & $\begin{array}{l}\text { Concentrations of triiodothyronine (T3) } \\
\text { and hyroxine (T4) in plasma }\end{array}$ & Grau (1987) \\
\hline $\begin{array}{l}\text { Fish tissue organic-chemical } \\
\text { residue analyses }\end{array}$ & $\begin{array}{l}\text { Direct measurement of a suite of } \\
\text { organic chemicals in fish tissue }\end{array}$ & $\begin{array}{l}\text { Concentrations of OCPs, total PCBs in } \\
\text { individual white suckers }\end{array}$ & Orazio and others (2006) \\
\hline $\begin{array}{l}\text { Mercury residue analyses of fish } \\
\text { muscle plugs }\end{array}$ & $\begin{array}{l}\text { Direct measurement of methyl } \\
\text { mercury in fish muscle plugs }\end{array}$ & $\begin{array}{l}\text { Concentration of methyl mercury in } \\
\text { muscle plugs extracted from } \\
\text { largemouth bass }\end{array}$ & May and others (2006) \\
\hline Fish plasma residue chemistry & $\begin{array}{l}\text { Direct measurement of contaminants } \\
\text { in blood plasma }\end{array}$ & $\begin{array}{l}\text { Concentrations of emerging } \\
\text { contaminants and select } \\
\text { pharmaceuticals in plasma }\end{array}$ & Leiker and others (2006) \\
\hline
\end{tabular}


Table 4. Supplementary methods and measurements used to assess ecological condition, invertebrate and fish communities, and contaminant exposure and effects in fish residing in the Charles River, Mass. Acronyms used in table are footnoted below.-Continued

\begin{tabular}{|c|c|c|c|}
\hline Method & Description & Metric & Reference \\
\hline Bile metabolites & $\begin{array}{l}\text { Indication of recent exposure to } \mathrm{PAH} \\
\text { contaminants }\end{array}$ & $\begin{array}{l}\text { Concentrations of PAH metabolites in } \\
\text { bile from gall bladder }\end{array}$ & Yang and others (2003) \\
\hline EROD activity & $\begin{array}{l}\text { Indication of exposure to planar } \\
\text { hydrocarbons }\end{array}$ & $\begin{array}{l}\text { PCBs; chlorinated dioxins and furans; } \\
\text { PAHs as measured from gill tissue }\end{array}$ & Jonsson and others (2002) \\
\hline Fish pathogens & $\begin{array}{l}\text { Evaluation on the presence of fish } \\
\text { pathogens associated with lesions } \\
\text { and internal organs }\end{array}$ & $\begin{array}{l}\text { Presence of bacteria and viruses } \\
\text { associated with lesions and the kidney, } \\
\text { spleen, and air bladder }\end{array}$ & Coll (2006) \\
\hline YES & $\begin{array}{l}\text { Evaluation on the presence of } \\
\text { estrogenic active substances }\end{array}$ & $\begin{array}{l}\text { Measurement of color change } \\
\text { (calculated as EC 50, a } 50 \text { percent } \\
\text { change in color) of yeast cells after } \\
\text { exposure to SPMD and POCIS extracts }\end{array}$ & Alvarez and others (2006) \\
\hline \multicolumn{4}{|l|}{ Biotic Community Assessments } \\
\hline Invertebrate community & $\begin{array}{l}\text { Assessment of benthic invertebrates } \\
\text { residing in depositional sediments as } \\
\text { an indication of habitat health and } \\
\text { contaminant exposure }\end{array}$ & $\begin{array}{l}\text { Species abundance and diversity, and } \\
\text { contaminant tolerance }\end{array}$ & Neilson and others (2003) \\
\hline Fish community & $\begin{array}{l}\text { Assessment of fish communities } \\
\text { associated with depositional habitats }\end{array}$ & $\begin{array}{l}\text { Species abundance and diversity } \\
\text { associated with depositional habitats }\end{array}$ & Moulton and others (2002) \\
\hline Chironomid deformities & $\begin{array}{l}\text { Determination of head capsule } \\
\text { deformities as an indication of } \\
\text { exposure to contaminants }\end{array}$ & $\begin{array}{l}\text { Number of chironomid head capsule } \\
\text { deformities for each species }\end{array}$ & Moulton and others (2000) \\
\hline \multicolumn{4}{|l|}{ Sediment and Water Chemistry } \\
\hline Organic analysis_-bulk sediments & $\begin{array}{l}\text { Direct measurement of organic } \\
\text { contaminants associated with } \\
\text { sediment }\end{array}$ & $\begin{array}{l}\text { Concentrations of total PCBs, OCPs, } \\
\text { PBDEs, and PAHs }\end{array}$ & Orazio and others (2006) \\
\hline
\end{tabular}


Table 4. Supplementary methods and measurements used to assess ecological condition, invertebrate and fish communities, and contaminant exposure and effects in fish residing in the Charles River, Mass. Acronyms used in table are footnoted below.-Continued

\begin{tabular}{|c|c|c|c|}
\hline Method & Description & Metric & Reference \\
\hline \multicolumn{4}{|l|}{ Artificial Samplers } \\
\hline SPMD & $\begin{array}{l}\text { Hydrophobic organic compounds } \\
\text { associated with water column }\end{array}$ & $\begin{array}{l}\text { Measurement of PCBs, PAHs, and } \\
\text { OCPs passively accumulated from } \\
\text { surface water over } 33 \text { days }\end{array}$ & Alvarez and others (2006) \\
\hline POCIS & $\begin{array}{l}\text { Water-soluble organic compounds } \\
\text { associated with water column }\end{array}$ & $\begin{array}{l}\text { Measurement of water-soluble (polar) } \\
\text { organic compounds accumulated by } \\
\text { passive sampler placed in surface water } \\
\text { for a minimum of } 33 \text { days }\end{array}$ & Alvarez and others (2006) \\
\hline \multicolumn{4}{|l|}{ Biotic Toxicity } \\
\hline Toxicity tests_-bulk sediment & $\begin{array}{l}\text { Growth and survival of aquatic } \\
\text { invertebrates after direct exposure to } \\
\text { contaminants associated with } \\
\text { sediment }\end{array}$ & $\begin{array}{l}\text { Growth and survival of Hyalella azteca } \\
\text { and Chironomus dilutus after 10-day } \\
\text { and 28-day exposures }\end{array}$ & Ingersoll (1995) \\
\hline $\begin{array}{l}\text { Microtox } ® \text { bioassay on SPMD } \\
\text { and POCIS extracts }\end{array}$ & $\begin{array}{l}\text { Evaluation of toxicity of extracts } \\
\text { from SPMD and POCIS samplers }\end{array}$ & $\begin{array}{l}\text { Measurement of bioluminescent output } \\
\text { of bacteria following exposure to } \\
\text { extracts expressed as EC } 50 \\
\text { (concentration of extract producing a } \\
50 \text { percent reduction in light compared } \\
\text { to controls) }\end{array}$ & Alvarez and others (2006) \\
\hline
\end{tabular}

(EC, effect concentration; EROD, ethoxyresorufin O-deethylase; OCP, organochlorine pesticides; PAH, polycyclic aromatic hydrocarbons; PCB, polychlorinated biphenyls; PBDE, polybrominated diphenyl ethers; POCIS, polar organic contaminant integrated sampler; SPMD, semi-permeable membrane device; YES, yeast estrogen screen) 


\section{Field Methods and Laboratory Analyses}

\section{Fish Collection}

The fish collection and processing procedures used for the Charles River Project followed those applied in previous BEST projects (Schmitt, 2002; Schmitt and others, 2004; Smith, Donahue, and others, 2002; Hinck and others, 2004). Two trophic guilds of fish (benthic and piscivorous) were targeted for sampling to reflect different contaminant exposure profiles associated with feeding strategies. Benthic-feeding fish tend to be exposed to persistent hydrophobic contaminants accumulated in sediments, whereas piscivorous fish are exposed to contaminants that accumulate in their prey. The BEST studies have focused on collecting common carp (Cyprinus carpio) as the benthic species and largemouth or smallmouth bass (Micropterus salmoides and M. dolomieu) as the piscivorous species. For this study, the white sucker (Catostomus commersoni, which is also a benthic species) was sampled since it is locally prevalent and has been used as a sentinel species to document contaminant pathologies, particularly in the Great Lakes and Canada. These species were selected because of their availability throughout the Charles River and their previously reported biomarker responses (Baumann and others, 1996). These species also correspond to guild selection criteria established by the BEST Program's Large River Program. The collection goal for each site was ten target species of each sex (ten males and ten females for a total $n=20$ per species). Fish were collected by electrofishing from a boat along both sides of the shoreline covering the entire river reach during August 8-23, 2005. Fish were held in live-wells prior to having their length and weight measured.

\section{On-Site Fish Processing}

Fish examination and tissue collection procedures are described in detail in previously published field protocols (Schmitt, Blazer, and others, 1999; Smith, Gross, and others, 2002). Approximately 5 milliliters $(\mathrm{mL})$ of whole blood was obtained from each fish via caudal vein puncture using a heparinized needle and syringe. One $\mathrm{mL}$ of the whole blood was placed in a sealable plastic vial, stored on wet ice, and shipped chilled $\left(0\right.$ to $4^{\circ} \mathrm{C}$ in coolers by overnight express mail to the U.S. Environmental Protection Agency, Ecological Exposure Research Division / National Exposure Research Laboratory in Cincinnati, Ohio) for the comet assay used to assess genetic damage. The remainder of the blood was centrifuged, and plasma from each fish was transferred to a labeled cryovial and then immediately frozen on dry ice for assessing levels of vitellogenin (an egg yolk protein) and sex steroid hormones (17 $\beta$ estradiol and 11 ketotestosterone).

After blood samples were drawn, fish were euthanized with MS-222, and remaining tissue samples were collected in the order described below. Samples of gill tissue were taken for analysis of EROD activity, an indicator of biochemical response to exposure to planar hydrocarbons. A subsample of axial muscle from largemouth bass was collected for mercury analysis. After gill and muscle plug samples were removed, fish were examined externally using a quantitative evaluation for external gross anomalies (Smith, Gross, and others, 2002). Skin growths and other external pathology were preserved in 10-percent buffered formalin for subsequent histopathology.

Necropsy procedures (Baumann and others, 1990) followed the external exam. Bile was extracted from the gall bladder via syringe and frozen in liquid nitrogen or dry ice for PAH metabolite analysis. Prior to examination for abnormalities, whole organs were weighed to the nearest gram using an electronic scale. Spleens and gonads were weighed for all three species, but livers (hepatosomatic index) were weighed only for bass. Samples of liver, spleen, gonad, kidney (both head and trunk), gill, 
and any lesion were taken and preserved for histopathological examination. An immunocytochemistry analysis was conducted on liver tissue to determine whether oncogenes (ras) and tumor suppressor genes ( $\mathrm{Rb}$ and $\mathrm{p} 53$ ) were present. Sections from the liver, spleen, and head kidney were examined microscopically to measure the proliferation of melanomacrophage centers (MMC). Gonad samples were examined for fecundity (females), stage of maturation, and the presence of anomalies. Duplicate sub-samples of liver tissue from each fish were obtained and frozen immediately in a dry ice/ethanol slurry for analysis of EROD activity, another indicator of exposure to planar hydrocarbons. Additional liver sub-samples also were frozen for assays of vitamins $\mathrm{C}$ and E. Spleen tissue was examined for macrophage aggregates.

Otoliths and scales were collected and labeled for subsequent age determination in the laboratory. Carp and bass carcasses were composited according to species and gender (10 samples per site) and frozen for analysis of persistent organochlorine compounds and metals. Organic extracts were also assayed for exposure to dioxin and dioxin-like compounds by using the H4IIE rat hepatoma bioassay. All other metrics were measured on individual fish.

\section{Determining Fish Age}

Ages of largemouth bass, carp, and white suckers were determined by counting annual rings on scales collected from the base of the dorsal fin above the lateral line or from the otoliths (Popper and Lu, 2000) collected from the brain cavity. Otoliths grow by the continuous deposition of calcium carbonate with no evidence of resorption. The age of the fish is estimated by counting the annuli, or opaque bands, with the aid of a dissecting microscope. The darker bands represent periods of fast growth. The lighter bands represent periods of slower growth. Fish scales grow annually and are used to determine fish age in much the same way annual growth rings are counted on otoliths. Typically, at least two separate readings of annual rings are performed and reconciled to confirm the ages determined from otoliths and scales (Campana and Nielson, 1985).

\section{Sediment and Water Chemistry}

\section{Semi-Permeable Membrane Device (SPMD) and Polar Organic Contaminant Integrated Sampler (POCIS)}

The semi-permeable membrane devices (SPMD) are designed to mimic key aspects of the bioconcentration process, which results in elevated contaminant concentrations in organism tissues after exposure to trace hydrophobic organic contaminants in aquatic environments. Sampling of compounds with moderate to high octanol-water partition coefficients $\left(K_{\mathrm{ow}}\right)$ greater than 3 is integrative (that is, extracted residues are constantly accumulated without significant losses back into the environment) and analyte concentrations are reported as time-weighted averages. Like the (SPMD), the polar organic contaminant integrated sampler (POCIS) is designed to mimic key aspects of the bioconcentration process and an organism's exposure to hydrophilic organic contaminants. The POCIS consists of a solid-phase sorbent or mixture of sorbents contained between two sheets of a microporous polyethersulfone membrane. Sampling compounds with low to moderate octanol-water partition coefficients $\left(K_{\text {ow }}\right)$ less than 3 is integrative and analyte concentrations are reported as time-weighted averages (Alvarez and others, 2006).

Both SPMD and POCIS (two replicates of each type) were deployed at a depth of $2.5 \mathrm{~m}$ in July, 2005, and recovered after 33 days (August 22, 2005). Locations where the devices were deployed are shown in figure 2 . 


\section{Whole-Sediment Residue Chemistry}

Whole-sediment residue chemistry identifies contaminants present in depositional sediments that may be toxic to aquatic biota. Bulk sediments were collected using methods described below in the "Fish and Invertebrate Communities" Section of this report. Several samples were homogenized into a single bulk sample, chilled on wet ice, and shipped to the Columbia Environmental Research Center (CERC), Columbia, Missouri. Methods for metal, organic, and inorganic chemical residue analysis and related information are found in Fishman and others (1994), Furlong and others (1996), Olson and others (2004), Skougstad and others (1979), and Van Metre and others (2000). Locations of bulk sediments used for sediment chemistry, toxicity, pore-water chemistry, and depositional invertebrate samples are shown in figure 2. Location coordinates are provided in table 3.

\section{Inorganic Chemistry Analysis of Sediments}

Sediments were homogenized and approximately $5-\mathrm{mL}$ aliquots were analyzed for acid volatile sulfide (AVS) and simultaneously extractable metals (SEM). To quantify AVS, homogenized sediment aliquots were reacted for one hour with $1 \mathrm{~N}$ hydrochloric acid in an oxygen-free atmosphere. The resulting hydrogen sulfide was purged with nitrogen into a sodium hydroxide trapping solution. Free sulfide ion is rapidly formed in the trap and measured by a sulfide-specific electrode. During the AVS sample preparation, an SEM fraction was generated (Brumbaugh and Arms, 1996). Forty mL of each extract was filtered through a 0.45 -micrometer $(\mu \mathrm{m})$ pore-size polypropylene cartridge. A portion of each filtered SEM extract $(10 \mathrm{~mL})$ was heated in a microwave oven with nitric acid/hydrogen peroxide. Evaporative digestion utilizing $50 \mathrm{~mL}$ Zymark1 tubes was performed on the extracts. Final dilution volume for the digestates was $100 \mathrm{~mL}$ in a matrix of one percent nitric acid.

An aliquant of homogenized sediment was dried at $95^{\circ} \mathrm{C}$ to constant weight in a convection oven to determine percent moisture. The dried sediment was then placed in a muffle furnace to find loss on ignition at $450^{\circ} \mathrm{C}$ (expressed as percent of dry weight). The remainder of each wet sediment sample was lyophilized, and then homogenized in a glass container by stirring with a glass rod until a uniform material was produced. To measure total recoverable metals, homogenized aliquots (approximately 0.25 gram $(\mathrm{g})$ ) were digested in 50-mL quartz reaction vessels by adding 5.5 mL HNO3 and $0.5 \mathrm{~mL} \mathrm{HCl}$. The sealed vessel was heated in a Perkin-Elmer multiwave oven. This digestion procedure allows one to measure total recoverable metals only, as it will not dissolve refractory mineral phases. The digestate liquid and all undissolved mineral components were transferred into a $125-\mathrm{mL}$ polyethylene bottle with ultrapure water to a final weight of $101.5 \mathrm{~g}(100 \mathrm{~mL})$. The final acid matrix was 5.5 percent $\mathrm{HNO} / 0.5$ percent $\mathrm{HCl}$ (percent by volume). An additional aliquant (approximately $0.25 \mathrm{~g}$ ), of each dried sediment was subjected to a magnesium nitrate-nitric acid dry-ashing procedure followed by hydrochloric acid reduction for the amounts of arsenic (As) and selenium (Se). Samples were boiled with nitric acid to solubulize and partially oxidize inorganic target analytes and were then ashed at $500^{\circ} \mathrm{C}$ with magnesium nitrate to complete the oxidation and decompose remaining organic matter. $\mathrm{HCl}$ was added to dissolve the ash and reduce Se to the $\mathrm{Se}+4$ oxidation state required for hydride generation. Following reduction, digestates were diluted to approximately $25 \mathrm{~mL}$ (fish) or $100 \mathrm{~mL}$ (other matrices) with deionized water, yielding a final acid matrix of 10 percent hydrochloric acid (May and others, 2006).

\section{Organic Chemistry Analysis of Sediments}

The sediment samples were analyzed for PAHs, organochlorine pesticides (OCPs), polybrominated diphenyl ethers (PBDEs), and polychlorinated biphenyls (PCBs). Separate 5-g portions (dry weight) of 
sediment were prepared for the PCB and OCP analyses. Ten-g (dry weight) aliquots were required for $\mathrm{PAH} / \mathrm{PBDE}$ analysis. Sediment portions of similar consistency were sampled, although the portions of sample taken for analysis had visibly varying amounts of rock, silt, sand, and detritus. The samples were added to baked glass fiber soxhlet thimbles, spiked with deuterated surrogate standards, and extracted for 20 hours (hr) with $300 \mathrm{~mL}$ of dichloromethane with a cycle of 16 minutes (min). The extracts were rotary evaporated in a $35^{\circ} \mathrm{C}$ water bath to approximately $2 \mathrm{~mL}$ and quantitatively transferred to test tubes. The volume was reduced to $1 \mathrm{~mL}$ under a stream of nitrogen $\left(\mathrm{N}_{2}\right)$, and then any remaining dichloromethane was removed by adding $2 \mathrm{~mL}$ of hexane and once again reducing the volume to $1 \mathrm{~mL}$ under an $\mathrm{N}_{2}$ stream. Separate portions of extracts required different clean-up methods.

\section{Gas Chromatographic Analysis of PCBs}

Sample extracts were adjusted to a volume of $1 \mathrm{~mL}$. Extracts were spiked with PCB congeners 030 and 207 (40 nanograms (ng) each) as instrumental internal standards (IIS). Total PCBs were measured by gas chromatograph/electron-capture detection (GC/ECD). Analyses were performed using HewlettPackard 5890 Series II GCs with cool on-column capillary injection systems and Hewlett-Packard model 7673 autosamplers. For all analyses, a 3-m section of a 0.53 -mm (interior diameter) uncoated and deactivated capillary retention gap (Agilent, Palo Alto, California) was attached to each analytical column by a Press-Tight ${ }^{\circledR}$ (Restek Corp., Bellefonte, Pennsylvania) union. The analytical column was packed with DB-17HT $\left(0.25 \mu \mathrm{m} 50\right.$ percent phenyl-, 50 percent methylsilicone; Agilent, Palo Alto, Calif.). The $\mathrm{H}_{2^{-}}$ carrier gas was pressure regulated at 25 pounds per square inch (psi). The temperature program for the PCB analysis was as follows: initial temperature $60^{\circ} \mathrm{C}$, immediately increased to $150^{\circ} \mathrm{C}$ at $15^{\circ} \mathrm{C}$ per minute (min), then raised to $260^{\circ} \mathrm{C}$ at $1{ }^{\circ} \mathrm{C} / \mathrm{min}$, and finally raised to $300^{\circ} \mathrm{C}$ at $10^{\circ} \mathrm{C} / \mathrm{min}$, and held for $15 \mathrm{~min}$. Electron capture detector temperature was $330^{\circ} \mathrm{C}$.

Polychlorinated biphenyls were determined by the sum of congener's method using a GC capillary column. The capillary GC/ECD data were collected and archived in digital form. Data were processed using a PerkinElmer chromatography data system, which included the model 970 interface and version 6.2 of Totalchrom Workstation chromatography microcomputer software. A mixture of several Aroclors is used to produce the PCB calibration standards. These standards have been quantified based on pure primary PCB standards (Accustandard, New Haven, Connecticut) and are used as secondary standards. Up to nine levels of calibration are used to quantify total PCBs in the samples. The PCB calibration curve spanned from 10 to $8,000 \mathrm{ng} / \mathrm{mL}$.

\section{Gas Chromatographic Analysis of OCPs and PBDEs}

Organochlorine pesticides were determined in the two fractions of each set at a final volume of 1 $\mathrm{mL}$. PBDEs and toxaphene was determined in fraction SODS-2. Internal standards for PCBs 030 and 207 were added. Individual OCPs were measured by GC/ECD. Analyses were performed using HewlettPackard 5890 Series II GCs with cool on-column capillary injection systems and Hewlett-Packard model 7673 autosamplers. For all analyses, a 3-m section of $0.53-\mathrm{mm}$ (interior diameter) uncoated and deactivated capillary retention gap (Agilent, Palo Alto, Calif.) was attached to each analytical column by a Press-Tight ${ }^{\circledR}$ (Restek Corp., Bellefonte, Penn.) union. The analytical columns were $60-\mathrm{m} \times 0.25-\mathrm{mm} \times$ $0.25-\mu \mathrm{m}$ DB-5 and DB-17HT phase columns. The $\mathrm{H}_{2}$-carrier gas was pressure regulated at $25 \mathrm{psi}$. The temperature program for the pesticide analysis was as follows: initial temperature $60^{\circ} \mathrm{C}$, immediately raised to $150^{\circ} \mathrm{C}$ at $15^{\circ} \mathrm{C} / \mathrm{min}$, then increased to $260^{\circ} \mathrm{C}$ at $1^{\circ} \mathrm{C} / \mathrm{min}$, and finally raised to $300^{\circ} \mathrm{C}$ at $10^{\circ} \mathrm{C} / \mathrm{min}$, and held for $15 \mathrm{~min}$. Electron capture detector temperature was $330^{\circ} \mathrm{C}$. 
The dual column GC/ECD method is used to identify and quantify OCP peaks from one column or the other based upon known standards. The GC/ECD data were collected, archived in digital form, and processed using a PerkinElmer chromatography data system. The system included model 970 interface and Version 6.2 Totalchrom Workstation Chromatography software. Six levels of OCP standards (29 components) were used for calibration, with each pesticide at concentrations ranging from 0.1 to 80 $\mathrm{ng} / \mathrm{mL}$. Organochlorine pesticide results are presented in tables designated by their CERC database number and are cross-referenced to their field identification number. Concentrations are expressed as nanograms of analyte per gram (ng/g) of sample (wet weight). Detection limits were calculated as discussed above for PCBs. Nine PBDE congeners were quantified by GC/ECD: PBDEs \#28, \#47, \#66, $\# 85, \# 99, \# 100, \# 153, \# 154$, and $\# 183$. These are the typical congeners of the penta-BDE and oct-BDE formulations accumulated in fish tissue. These PBDEs were separated from the pesticides by the dual column GC/ECD method. Total toxaphene concentrations were determined semi-quantitatively in the SODS-2 fraction on the DB17HT column. The method quantifies twenty significant peaks in the standards as a group. Four levels of toxaphene standards were used for calibration, ranging from 50 to $500 \mathrm{ng} / \mathrm{mL}$ concentrations. Detection limits were calculated from the procedure blanks run with these samples by using the method of Keith and others (1983).

\section{Gas chromatographic/Mass Spectrometric Analysis (GC/MS) of PAHs}

The PAH fraction was adjusted to a final volume of approximately 100 microliters $(\mu \mathrm{L})$ to which the instrumental internal standard p-terphenyl-d14 (100 ng) was added. The sixteen perdeuterated and twenty-seven native PAHs were measured by GC/MS using a CE Instruments 8000Top GC with cool oncolumn capillary injection system and an AS800 auto-sampler ( $2 \mu \mathrm{L}$ injected) interfaced with a Voyager quadrupole mass spectrometer (Thermo-Finnigan Corp., San Jose, Calif.) A 2.5-m section of 0.53-mm (internal diameter) uncoated and deactivated (Restek Corp., Bellefonte, Penn.) capillary retention gap was attached to the front of each analytical column by a Press-Tight ${ }^{\circledR}$ (Restek Corp., Bellefonte, Penn.) union. The analytical column was a 50 -m $\times 0.20$-mm Ultra-2 $(0.11 \mu \mathrm{m} 5$ percent phenyl-, 95 percent methylsilicone, Agilent, Palo Alto, Calif.). Helium carrier gas was flow regulated at $1 \mathrm{~mL}$ per minute. The temperature program for the $\mathrm{PAH}$ analysis was as follows: initial temperature $60^{\circ} \mathrm{C}$, hold time $2.5 \mathrm{~min}$, increased to $300^{\circ} \mathrm{C}$ at $5^{\circ} \mathrm{C} / \mathrm{min}$, and held for $15 \mathrm{~min}$. The direct transfer line to the mass spectrometer was maintained at $305^{\circ} \mathrm{C}$.

The mass-spectrometric method acquired full scan data mass and archived in digital form, and processed using the Thermo-Finnigan XCalibur GC/MS data system. Depending on the dynamic range required, calibration of up to eleven levels of calibration standards, ranging from 1-2,500 picograms per microliter $(\mathrm{pg} / \mu \mathrm{L})$, were analyzed with an analytical set. Method detection limits were estimated from lowlevel standards and determined by both the signal-to-noise ratio of the peak in the quantitation ion channel and the gradual loss of unique characteristics of the background-corrected mass spectrum.

The concentration of PAHs contained in the $100 \mu \mathrm{L}$ of final extract prepared from the fieldcollected sediment samples were too concentrated and were diluted and analyzed again by GC/MS for accurate quantification. Sediment extracts were analyzed with recovery-tracking deuterated PAHs. However, due to the extremely high levels of native PAHs in the sediments, and the need to dilute the extracts, recoveries could not be monitored in each sample as is typically the case. Recovery information was obtained from the quality control samples. 


\section{Pore Water Chemistry}

Inorganic Chemistry Analysis

Filtered sediment pore-water samples were digested for subsequent analysis by inductively coupled plasma mass spectroscopy (ICP-MS), both quantitative and semi-quantitative, by placing $5 \mathrm{~mL}$ of sample into a 50-mL quartz reaction vessel, adding $1 \mathrm{~mL}$ nitric acid, and heating the sealed high pressure vessel assembly in a PerkinElmer Multiwave oven according to specifications in a pre-programmed method. After cooling, digestates were transferred to a storage container and diluted to a final volume of approximately $50 \mathrm{~mL}$. Final acid matrix was 2 percent (by volume) nitric acid (May and others, 2006).

\section{Fish Residue Chemistry}

\section{Fish Tissue Homogenization and Compositing}

Chemical residues in resident fish tissues provide evidence as to whether or not sediment-bound contaminants are cycling through the food web. Whole-fish chemical residue analyses reflect a mixture of contaminants and metabolites absorbed from three sources: diet, water, and contact with sediments. These body burdens may relate to toxicity, biomarker responses, and changes in fish health/community structure (Hoffman, 1996). Composite tissue samples prepared from whole fish for carp, largemouth bass, and white suckers were analyzed for metals and other inorganic contaminants. Composite tissue samples prepared from whole fish for carp and largemouth bass, and 30 individual white sucker tissue samples prepared from whole fish, were analyzed for organic contaminants.

Individual fish were partially thawed, sliced into 3- to 5-cm sections, and passed through a Hobart ${ }^{\circledR}$ commercial meat grinder equipped with an extrusion disk with approximately $0.5-\mathrm{cm}$ orifices. The resultant ground tissue was then re-mixed and passed through the grinder again. After three cycles of grinding and mixing, the samples were refrozen. Processed tissues from the three species (carp, white sucker, and largemouth bass) were composited by gender and prepared by weighing equal portions of each individual ground fish followed by manual mixing.

\section{Fish Tissue Inorganic Contaminant Analyses}

To prepare digestates of whole-body fish composites for analysis by ICP-MS semi-quantitative scan, an aliquant of each dried sample (about $0.25 \mathrm{~g}$ ) was heated with $6 \mathrm{~mL}$ nitric acid in a sealed, lowpressure Teflon vessel in a microwave oven. The cooled digestate liquid was transferred into a $125-\mathrm{mL}$ polyethylene bottle with ultrapure water to a final weight of $101.5 \mathrm{~g}(100 \mathrm{~mL})$. Final acid matrix was 6 percent $\mathrm{HNO}_{3}$. To prepare a digestate for As and Se, about $0.25 \mathrm{~g}$ of dried whole-body fish was dry-ashed following the same procedures as described previously for sediment samples. For the determination of $\mathrm{Hg}$, no chemical preparation was required, as the tissue was combusted directly as part of the analytical sequence (May and others, 2006).

\section{Fish Tissue Organic Contaminant Analyses (PCBs, OCPs, and Toxaphene)}

Ten-gram aliquots of the fish samples were dehydrated by blending with anhydrous sodium sulfate. Tissue mass was recorded to $0.01-\mathrm{g}$ accuracy. After drying, recovery compounds were added and fish samples were thoroughly extracted in glass columns with dichloromethane. A 1-percent portion of the extract was used to gravimetrically determine percent lipid after evaporation of solvent. Lipids and co-extracted biogenic materials were removed from the extracts by low-pressure gel permeation chromatography, followed by high-pressure size-exclusion chromatography (HPSEC) for total PCBs and OCP analyses. The 
extracts were then applied to a two-layered octadecyl silica/activated silica (SODS) gel column and separated into two fractions: one fraction containing PCBs and six of the targeted OCPs (SODS-1), and a second fraction containing the remainder of the OCPs (SODS-2) (Orazio and others, 2006).

\section{Muscle Plug Hg Chemistry}

Ten muscle-plug samples (Waddel and May, 1995) from each largemouth bass were combusted directly to a dried tissue state for the determination of Hg. A DMA-80 analyzer was used to conduct direct mercury analysis (DMA) of fish tissue. The process incorporates thermal combustion, amalgamation, and atomic absorption spectroscopy. Quality control included calibration verification checks, reference tissues, replicates, method spikes, and blanks. All quality control results were tabulated to provide an overview of quality assurance and to facilitate interpretation. Reference fish tissues were used to confirm calibration of the DMA-80. Dried samples (30-40 mg) were combusted in a stream of oxygen. All $\mathrm{Hg}$ in the samples was volatilized and trapped by amalgamation on a gold substrate, followed by thermal desorption and quantification by using atomic absorption spectrophotometry (U.S. Environmental Protection Agency, 2000). The entire sequence was conducted with a Milestone DMA-80 analyzer equipped with an automated sample carousel. $\mathrm{Hg}$ produced recoveries ranging from 97 to 108 percent. Spikes of $\mathrm{Hg}$ in a reference muscle tissue ranged from 86 to 119 percent. The detection level for mercury in muscle plugs was 0.005 micrograms per gram $(\mu \mathrm{g} / \mathrm{g})$ dry weight (May and others, 2006).

\section{Bile Metabolites}

Since PAHs are metabolized by vertebrates, tissue concentrations in fish are not correlated with exposure. However, PAH metabolites in bile indicate exposure and correlate well to abnormalities and tumors associated with PAHs (Yang and others, 2003). Estimation of selected metabolites of aromatic compounds in bile followed the reverse phase HPLC technique with fluorescence detection reported in Krahn and others (1984). The fluorescence detectors were set at excitation/emission wavelength pairs for both benzo[a]pyrene and naphthalene. PAH metabolite concentrations were normalized to protein content by a modified Lowry method (Lowry and others, 1951).

\section{Plasma Chemistry}

Chlorinated organic compounds in fish plasma were extracted and analyzed with gas chromatography/mass spectroscopy (GS/MS) according to the following procedures. A 2-g (about $2 \mathrm{~mL}$ ) sample of plasma was stirred with $27 \mathrm{~g}$ of granular anhydrous sodium sulfate to remove water from the sample. Extraction cells of a DionexR Model 200 Accelerated Solvent Extractor (ASE) were prepared by adding $5 \mathrm{~g}$ of florisil. The sodium sulfate homogenate was then added to the top of the extraction cell. Two fractions were generated using the ASE. The first fraction was produced by extracting the 2-g sample of plasma with hexane. The sample was then re-extracted on the ASE using a 5-percent isopropanol/hexane (IPA/hexane) solution to produce a second fraction. Fraction 1 (hexane extraction) contained PCBs, DDEs, BDEs, and other nonpolar organics. Fraction 2 (IPA/hexane) contained endosulfan compounds and other, more polar, organic compounds. Both fractions were combined and concentrated to a volume of $500 \mathrm{uL}$ by using a Kuderna-Danish (K-D) apparatus, followed by nitrogen evaporation. Duplicate analysis of target compounds was performed using capillary-column GC/MS detection under electron-capture negative ion chemical ionization (ECNICI) conditions (Lieker and others, 2008). 


\title{
Toxicity Tests Associated with Sediment and Extracts from SPMD and POCIS Samplers
}

\author{
Whole-Sediment Chronic Toxicity
}

The potential toxicity of sediments to resident biological organisms can be assessed using a variety of approaches. In the current study, sediment toxicity was assessed by exposing lab-cultured, sediment dwelling macroinvertebrates to field collected sediment samples under controlled laboratory conditions (Ingersoll, 1995). Toxicity tests were performed on three field collected sediment samples collected from depositional zones within the study area. Each bed sediment sample represented a composite of three sediment grabs taken in close proximity to one another (fig. 2). The toxicity of the field-collected sediment samples was evaluated using two macroinvertebrates species: an amphipod (Hyalella azteca) and the larval form of a midge (Chironomus dilutus). Laboratory analysis included the use of control sediments as described by Ankley and others (1994) and Ingersoll and others (2005). All sediment toxicity tests were started within three weeks of sample collection from the field. Sediments were not sieved to remove indigenous organisms during homogenization of samples in the laboratory before the start of the toxicity test.

Whole sediment toxicity tests were conducted with Hyalella azteca for 28 days according to methods described in American Society for Testing and Materials (2007) and Burton and others, (1996). Endpoints measured in the amphipod exposures included survival and growth (length) on Day 28. Test sediments were homogenized and added to exposure beakers one day before test organisms were added. Amphipods were exposed to $100 \mathrm{~mL}$ of sediment with $175 \mathrm{~mL}$ of overlying water in $300-\mathrm{mL}$ beakers. A total of eight replicates/sediment treatments were conducted. The photoperiod was $16 \mathrm{hr}$ of light: $8 \mathrm{hr}$ of dark at an intensity of about 200 lux at the surface of the exposure beakers. The exposure temperature was $23^{\circ} \mathrm{C}$. Each beaker received 2-volume additions/day of overlying water starting on Day -1 , and then $50 \mathrm{~mL}$ of water was delivered automatically to each beaker every $4 \mathrm{hr}$ (plus or minus $15 \mathrm{~min}$ ). Tests were initiated (Day 0) by placing 10 amphipods into each beaker using an eyedropper. Amphipods in each beaker were daily fed $1.0 \mathrm{~mL}$ of Yeast-Cerophyll-trout chow (YCT; 1.7 to 1.9 grams per liter $(\mathrm{g} / \mathrm{L})$ in a water suspension. Beakers were observed daily for the presence of animals, signs of animal activity (burrowing), and to monitor test conditions (mainly water clarity). On Day 28, amphipods were recovered from each beaker by decanting overlying water, gently swirling remaining water and upper layer of sediment, and washing the sediment through a no. $50(300-\mu \mathrm{m}$ opening $)$ U.S. standard stainless steel sieve. The retained materials were washed into a glass pan and the surviving amphipods were removed. Amphipods from 4 replicates of each sediment sample were counted and preserved in 8-percent sugar formalin for subsequent length measurements (Ingersoll and others, 2002). The length of amphipods was measured along the dorsal surface from the base of the first antenna to the tip of the third uropod along the curve of the dorsal surface. Amphipod length measurements were made using an EPIX imaging system (PIXCI® SV4 imaging board and XCAP software; EPIX Inc., Buffalo Grove, Illinois) connected to a computer and a microscope (Ingersoll and others, 2002).

Midge exposures were similar to amphipod exposures with the following exceptions: (1) due to collection time, only 2 field collected samples were evaluated, (2) exposures were 10 days, (3) midge were fed $1.5 \mathrm{~mL}$ of Tetrafin, and (4) the grow endpoint was ash-free dry weight. On Day 10, surviving midge were collected following procedures described above and placed into a pre-weighed weigh pan (organisms that had reached the pupal stage were counted as surviving but not used in growth determination). Samples were dried at $60^{\circ} \mathrm{C}$ for $24 \mathrm{hr}$ and weighed (dry weight). Samples were then ashed for $2 \mathrm{hr}$ at $550^{\circ} \mathrm{C}$ and then reweighed. 


\section{Microtox ${ }^{\circledR}$ Bioassay}

The Microtox assay uses a suspension of luminescent marine bacteria: Vibrio fischeri (NRRL B11177, also referred to as Photobacterium phosphoreum, Strategic Diagnostics, Inc., Newark, Delaware). $V$. fischeri produces light as a by product of cellular respiration. When exposed to certain toxicants, the rate of light production is reduced in proportion to the sample toxicity. The Microtox ${ }^{\circledR}$ bioassay was completed on subsamples extracted from SPMD and POCIS samples. An aliquot of the bacterial suspension was transferred to a test vial containing the standard diluent ( 2 percent $\mathrm{NaCl}$ ) and equilibrated at $15^{\circ} \mathrm{C}$ using a temperature-controlled photometer. Light readings of each test vial were taken before the addition of test samples and following a 5-min and 15-min incubation period. Light loss was expressed as a gamma value and defined as the ratio of light loss to light remaining. The relative sensitivity of Microtox ${ }^{\circledR}$ has been reported by Kaiser and Palabrica (1991) and Johnson and Long (1998). To determine the dose response and the concomitant toxicity, each sample solution was diluted into four test concentrations. The log of the gamma values from these four dilutions was plotted and compared with the $\log$ of the sample concentrations. The concentration of the extract that was determined to inhibit luminescence by 50 percent after the 5-min exposure period $\left(\mathrm{EC}_{50)}\right.$ was determined and expressed as $\mathrm{mg}$ equivalent of sample. Data were analyzed using the Microtox Omni software package (version 1.18, Strategic Diagnostics, Inc., Newark, Del.). Phenol was used as the positive toxicity control for the Microtox ${ }^{\circledR}$ bioassay. Dimethylsulfoxide (DMSO) was used as the carrier vehicle for the samples and as the negative control. Results are reported in terms of an effective concentration (EC), which is the estimated concentration of sample required to produce the desired level of metabolic inhibition (light loss). The $\mathrm{EC}_{50}$ value is the typical endpoint used to report and compare Microtox ${ }^{\circledR}$ data. $\mathrm{EC}_{50}$ values were reported as the means of three replicate determinations with variability expressed as standard deviations.

\section{Fish Health Biomarkers}

\section{Quantitative Organism-Level Indicators}

Gross pathologies were selected for consistency with other monitoring programs (Fournie and others, 1996). Gross abnormalities included grossly visible disorders of the eye (exophthalmia, hemorrhage, opacity, emboli), opercles (shortening, deformities, parasites), body surface (ulcers, parasites, discolored areas, raised growths), and disorders of the fins and skeleton. The health assessment index (HAI) was the method used to identify internal and external lesions for each fish during field necropsy. Numerical values were assigned to internal and external observations of anomalies and lesions recorded in the field, and a necropsy-based fish health assessment index (HAI) score was calculated for each fish by summing these values for all organs (Blazer and others, 2002). Body and organ weights were used to compute condition factor $(\mathrm{CF})$ and organosomatic indices according to the following formulae: $\mathrm{CF}=$ body weight in $\mathrm{g} /(\text { length in } \mathrm{cm})^{3}$; hepatosomatic index $(\mathrm{HSI})=$ liver weight/(total body weight - gonad weight) $\times 100$; splenosomatic index $(\mathrm{SSI})=$ spleen weight $/($ total body weight - gonad weight $) \times 100$; and gonadosomatic index $(\mathrm{GSI})=(\operatorname{gonad}$ weight/total body weight $) \times 100$. The weight of the gonads was subtracted from the body weight to minimize the effect of the reproductive cycle on the HSI and SSI. The HSI was calculated only for fish species that have a discreet liver (largemouth bass).

\section{Sex Steroid Hormones: 17 B Estradiol and 11 Ketotestosterone}

Plasma samples from largemouth bass were analyzed for 17ß-estradiol and 11-ketotestosterone using radioimmunoassay (RIA) procedures. Plasma samples $(50 \mu \mathrm{l})$ were extracted twice with $5-\mathrm{mL}$ diethyl ether prior to RIA analysis. Each sample was analyzed in duplicate for both 17ß-estradiol and 11- 
ketotestosterone and corrected for extraction efficiencies of 92 plus or minus 2.8 percent and 86 plus or minus 3.3 percent, respectively. Standard curves were prepared in a buffer with known amounts of radioinert 17ß-estradiol or 11-ketotestosterone $(1,5,10,25,50,100,250,500$, and 1,000 picograms (pg). The minimum concentration detectable was $6.4 \mathrm{pg} / \mathrm{mL}$ for $17 \beta$-estradiol and $8.1 \mathrm{pg} / \mathrm{mL}$ for 11 ketotestosterone. Cross-reactivities with other steroids for the $17 \beta$-estradiol antiserum were as follows: 11.2 percent for estrone, 1.7 percent for estriol, less than 1.0 percent for $17 \alpha$-estradiol and androstenedione, and less than 0.1 percent for all other steroids examined. Cross-reactivities of the 11ketotestosterone antiserum with other steroids were 9.7 percent for testosterone, 3.7 percent for adihydrotestosterone, less than 1.0 percent for androstenedione, and less than 0.1 percent for all other steroids examined. A pooled sample (approximately $275 \mathrm{pg}$ of 173 -estradiol/mL and $220 \mathrm{pg}$ of 11 ketotestosterone/mL) was assayed serially in 10-, 20-, 30-, 40-, and 50- $\mu$ l volumes (final volume of $50 \mu 1$ with charcoal-stripped plasma). Further characterization of the assays involved measurement of known amounts $(1,2,5,10,25,50,100,250$, and $500 \mathrm{pg})$ of $17 ß$-estradiol or 11 - ketotestosterone in $50 \mu 1$ of charcoal-stripped plasma. Correlation values $\left(\mathrm{R}^{2}\right)$ between actual and measured amounts during the calibration were 0.93 for $17 ß$-estradiol and 0.88 for 11 -ketotestosterone. Inter-assay and intra-assay coefficients of variation were 7.3 and 9.5 percent for plasma 17ß-estradiol, respectively, and 9.1 and 8.7 percent for plasma 11-ketotestosterone, respectively (Bevans and others, 1996; Goodbred and others, 1997; Schmitt and Dethloff, 2000).

\section{Yeast Assay}

The yeast estrogen screen (YES) uses recombinant yeast cells transfected with the human estrogen receptor. The recombinant yeast cells also contain expression plasmids carrying a reporter gene (lac-z). Following the binding of a suitable agonist, the yeast cells undergo a cascade of events that results in the release of $\beta$-galactosidase into the growth media. The $\beta$-galactosidase interacts with a chromogenic substrate (chlorophenol red- $\beta$-D-galactopyranoside $[\mathrm{CPRG}]$ ) in the media, producing a color change that can be measured spectrophotometrically. This color change is a measure of the estrogenic potential of chemicals in the sample.

Yeast cultures were removed from storage and grown for $24 \mathrm{hr}$ at $30^{\circ} \mathrm{C}$ to determine their viability prior to inoculating the test plates. Sample extracts were solvent exchanged into ethanol to prevent damage to the test plate. The test plates were prepared by adding a positive control in the first row and alternating negative controls $(200 \mu \mathrm{L}$ ethanol) and test sample $(100 \mu \mathrm{L}$ extract diluted with $100 \mu \mathrm{L}$ ethanol in triplicate) in the following rows. All samples and controls were then serially diluted across the test plate. The liquid in each well was allowed to evaporate prior to adding $200 \mu \mathrm{L}$ of assay medium containing approximately $4 \times 10^{7}$ recombinant yeast cells and CPRG. The plates were gently agitated, sealed, and incubated at $30^{\circ} \mathrm{C}$ for up to $72 \mathrm{hr}$. Each day, the plates were inspected for the conversion of CPRG in the positive controls to determine the speed of plate development. After $48 \mathrm{hr}$, the plates were allowed to finish developing at room temperature. The plates were read using a Labsystems Multiskan MS type 352 with the Genesis II software (Labsystems, Finland) measuring the absorbance at 540 and 620 nanometers (nm) (Alvarez and others, 2006).

\section{Vitellogenin}

Vitellogenin concentrations in largemouth bass plasma were assayed and quantified by an EnzymeLinked Immunosorbent Assay (ELISA), as described by Goodbred and others (1997) and summarized below. Initially, vitellogenin from bass was purified by ion-exchange chromatography (Denslow and others, 1999) for use in the standard. The monoclonal antibody Mab HL 1080 1C8-3C11 was used in the 
ELISA assay. This antibody reacts specifically to largemouth bass vitellogenin and not with other plasma proteins. Purified antibody was diluted to 10 milligrams per milliliter $(\mu \mathrm{g} / \mathrm{mL})$ in phosphate-buffer saline and coated onto 96 -well plates $(50 \mu \mathrm{g} / \mathrm{mL} /$ well $)$, and stored overnight at $4^{\circ} \mathrm{C}$. Plates were washed with trisbuffered saline containing 0.05 percent Tween (TBST) blocked with 0.1 percent bovine serum albumin in TBST for $2 \mathrm{hr}$ at room temperature, and thoroughly washed again three times with TBST. Plasma samples were diluted from 1:100 to 1:5,000 in 0.1 percent bovine serum albumin in TBST, and 50 micrograms $(\mu \mathrm{g})$ of these samples were added in duplicate to plate wells and incubated overnight. Standard curves were from 10 to $1,000 \mathrm{ng} / \mathrm{mL}$, and were constructed in male plasma at the same dilution as the sample to be analyzed. Of this solution, only $50 \mu \mathrm{g}$ were placed in the well. Although the assay itself is very sensitive, plasma samples need to be diluted at least to 1:100 to eliminate interferences that affect the assay, thus making the assay sensitive to 0.001 milligrams per milliliter $(\mathrm{mg} / \mathrm{mL})$. Male control plasma was made from composites of plasma from fish collected at an uncontaminated site, which was shown by Western Blot assay to have no vitellogenin. The next day, plates were washed with TBST, incubated with $50 \mu \mathrm{g}$ per well rabbit anti-vitellogenin polyclonal antibody UF114 (produced and characterized by the University of Florida), diluted to 1:500, and incubated for $2 \mathrm{hr}$ at room temperature. This discloses the vitellogenin captured by the monoclonal antibody in the first step. The polyclonal antibody was in turn disclosed by a goat anti-rabbit immunoglobulin ( $\mathrm{IgG})$ linked to alkaline phosphatase and incubated for $2 \mathrm{hr}$ at room temperature.

After a final series of washes with TBST, $100 \mu \mathrm{g}$ of p-nitro-phenyl-phosphate in carbonate buffer ( $\mathrm{pH}$ 9.6) was added to each well and incubated for $30 \mathrm{~min}$. The intensity of yellow color that developed was quantified at $405 \mathrm{~nm}$ with an automated ELISA reader. Vitellogenin concentrations were calculated from standard curves after subtracting the small nonspecific color reaction (around $0.2 \mathrm{~A}, 405 \mathrm{~nm}$ ) with male control plasma. The ELISA assay used in this study can detect between 10 and $100 \mathrm{ng}$ of vitellogenin per well, resulting in a sensitivity of about $0.001 \mathrm{mg} / \mathrm{mL}$. Each ELISA assay included a positive control (plasma with a known vitellogenin concentration) to test for inter-assay and intra-assay variation. The coefficient of variation was calculated for each duplicate sample and, if it exceeded 10 percent, samples were rerun. Standard curves fit by linear regression were used to calculate vitellogenin concentration, with $\mathrm{R}^{2}$ values usually between 0.95 and 0.99 (Denslow, Chow, Chow, and others, 1996; Denslow, Chow, Kroll, and others, 1996; Denslow and others, 1997; Schmitt and Dethloff, 2000).

\section{Histological Determination of Sexual Maturation}

Samples of male and female gonads were dissected in the field, fixed in Bouins' solution or 10 percent neutral buffered (sodium phosphate) formalin, and transferred to 100-percent ethanol in the laboratory prior to processing. Testes were cut longitudinally and ovaries were cut transversely. Samples were embedded in paraffin, sectioned to $5 \mu \mathrm{m}$, and stained with hematoxylin and eosin for histological evaluation. All tissue slides were evaluated for reproductive stage, anomalies, and gonadal parasites.

Gonads of female fish were classified according to four stages of sexual maturation, based on evaluation of histological slides (Blazer, 2002). Ovaries containing mostly perinucleolar oocytes at various stages of pre-vitellogenic growth were classified as undeveloped (stage 0). Ovaries showing a mixture of both perinucleolar and cortical alveoli oocytes were classified as early vitellogenic (stage 1). Ovaries classified as early-mid vitellogenic (stage 2) had some vitellogenic oocytes of various sizes and development, with few to moderate numbers of vitelline granules, and few fully developed oocytes. Late vitellogenisis was classified as stage 3 or 4: ovaries in which most oocytes were at or near maximum size and contained numerous, densely packed vitelline granules. Stage 4 ovaries were considered vitellogenic but post-ovulatory. Stage 5 females were post vitellogenic. 
Male gonads were classified according to three stages of sexual maturation. Undeveloped testes with no spermatogenesis were considered Stage 0 . Testes that were classified as early spermatogenic (stage 1) had thick germinal epithelium, with diffuse, pronounced proliferation and maturation of spermatozoa. Mid-spermatogenic (stage 2) testes had germinal epithelium of moderate thickness, with diffuse moderate proliferation and maturation of sperm. Testes classified as late spermatogenic (stage 3) had mostly thin germinal epithelium, with only scattered spermatogenic activity characteristic of testes during late stage maturity (Goodbred and others, 1997; Schmitt and Dethloff, 2000).

\section{Fecundity}

The total yearly production of viable eggs in female fish is a critical factor in maintaining sustainable populations. Many studies have shown that exposure to contaminants increases the number of atretic (non-viable) eggs, reduces egg size (which reduces chances of fertilization and larval success), and lowers the gonadosomatic index (the weight of the ovaries as a percent of body weight; Kumar and Pant, 1988; Rastogi and Kulshrestha, 1990; Collier and others, 1992). In addition, the body burdens of environmental contaminants in adult female fish are transferred to developing eggs. An estimate of potential fecundity (number of viable eggs likely to be produced) can be derived by taking sub-samples from the ovary in the field; preserving the tissue; and conducting assessments of egg numbers, size distribution, and stage of gonadal maturation (Patino and others, 2003).

\section{Sperm Quality}

Successful reproduction is essential to maintaining viable fish populations. Recent studies have shown that male fish exposed to environmental contaminants have impaired reproduction and sperm quality (Patino and others, 2003; Sepulveda and others, 2003; Toft and others, 2003). Detailed methods used to evaluate sperm quality have been developed for fish by Kime and Nash (1999). Sperm can be collected easily in the field at appropriate times of the year by using abdominal palpation. Semen was placed in a salt solution and analyzed with a field microscope to determine activation and several additional measurements: sperm motility (estimate of percent of total sperm actively moving), sperm progressive status (estimate of sperm movement/status on a scale of 1 to 5), sperm concentration (utilization of fixed sample for cell counts), and sperm morphology (evaluation of fixed and stained preparation to evaluate for normal versus abnormal morphology).

\section{Histopathology}

Histopathology is crucial in linking carcinogenic contaminants to tumors and other pathology in fish. Polycyclic aromatic hydrocarbons have been associated with tumors in seven species of freshwater fish from 17 different wild populations in eastern North America (Baumann, 1998). Preparation of tissues for histopathology followed the protocol of the Registry of Tumors in Lower Animals as previously published (Baumann and others, 1990). Tissue samples were taken from all visible lesions, and from the liver, gonad, spleen, and kidney, and preserved in 10 percent buffered formalin. After 5-7 weeks of fixation, tissue samples were processed for paraffin embedding, sectioned at 4-mm thickness, mounted on glass slides, and stained with hematoxylin and eosin. Three to six slides were examined for each fish. Additional diagnostic techniques, such as immunocytochemistry (ICC), including markers for oncogenes (ras) and tumor suppressor genes ( $\mathrm{Rb}$ and $\mathrm{p} 53$ ), were applied to evaluate histological lesions.

Commercially available ICC reagent was applied according to manufacturer's directions. Representative, tumor-free organ samples from the same fish were used as negative controls; positive controls consisted of appropriate tumor samples from the collection of vertebrate tumors in the archives of the Veterinary 
Diagnostic Laboratory, University of Connecticut. In addition, sections from the liver, spleen, and head kidney were examined morphometrically to measure the proliferation of MMCs. The areas of MMC were calculated within 10 randomly chosen, high-power fields HPF (400 magnification) in each section (3 sections per organ per fish), 30 fields for each organ. The mean value of all 30 measurements constitutes the final result for each fish. A digital camera and morphometric software (SPOT Insight and SPOT SOFTWARE 4.1, Diagnostic Instruments, Inc., Sterling Heights, Michigan) were used. All tissues were examined blindly by a veterinary pathologist using an Olympus BX41 light microscope with the SPOT Insight camera. Slides are archived at the Northeastern Research Center for Wildlife Diseases at the University of Connecticut, and sections of tumors will be archived at the Registry of Tumors in Lower Animals, at the Environmental Pathology Laboratories, Sterling, Virginia.

\section{Bacteria and Viruses Collected from Fish}

All fish were sampled for microbiology as soon after collection as possible. Fish were euthanized upon collection and held on ice until samples could be taken. Between individuals sampled, dissecting tools and surfaces were cleaned and then disinfected with 70 percent isopropyl alcohol. Bacteriological samples were taken first to reduce the chance of contamination. When external lesion(s) were observed, a brain heart infusion agar (BHIA) slant was streaked directly from the lesion, using a sterile inoculating loop. The loop and recap slant were discarded, leaving the cap loosened. With sterile scissors or scalpel, a cut into the abdomen was made at the base of the pectoral fin and continued dorsally to just below lateral line. The incision was started again at the base of the pectoral fin and continued towards the posterior of the fish along the ventral abdominal wall to the vent. The kidney was then stabbed with the sterile loop end and streaked onto BHIA slant. Small amounts of kidney tissue from each fish were collected and combined with kidney tissues from other fish for a total of five tissue samples in a Whirlpak bag. Samples were kept chilled on ice $\left(4^{\circ} \mathrm{C}\right)$ during collection and shipment. Virology samples for bass included kidney, spleen, and air bladder (K/S/A); samples for carp and white sucker included only kidney/spleen (K/S). Samples were kept on ice during sampling and shipment (Coll, 2006).

\section{Comet Assay}

Using whole blood cells, this assay has been developed as a sensitive marker of contaminantcaused genetic damage in fish (Meier and others, 2001). The single cell gel or "comet assay" uses electrophoresis to separate and measure intact and fragmentary DNA within a single cell nucleus. The term "comet" comes from the shape the genetic material forms during the assay, with the intact DNA in a tight center sphere while the fragmentary pieces stream back like a comet tail. The comet assay was performed at the EPA National Exposure Research Laboratory, Cincinnati, Ohio, and was based on the method developed by Singh and others (1988). Two slides were prepared for each fish and 50 cells scored on each slide. Slides were put into a lysing solution, immersed in electrophoresis buffer to allow unwinding of DNA, and then subjected to electrophoresis and stained. Slides were observed under a fluorescent microscope and image analysis was used to quantify tail length and percent tail DNA.

\section{Indicators of Chemical Exposure}

\section{Liver EROD Activity}

Measurement of ethoxyresorufin- $O$-deethylase (EROD) activity in fish is a well-established biomarker of exposure and response to certain planar halogenated hydrocarbons (PHHs) and PAHs and other structurally similar compounds (Whyte and others, 2000). Liver EROD activity is performed on 
small liver samples dissected from fish immediately after being euthanized. Liver tissue was immediately cryogenically frozen in the field and stored at $-78^{\circ} \mathrm{C}$ until it could be processed at the laboratory. The procedures for laboratory preparation and analysis are described by Schmitt and others (2002).

\section{H4IIE Bioassay}

The H4IIE rat hepatoma cell line bioassay is used to detect and semi-quantify specific classes of PHHs and related compounds. The H4IIE bioassay was performed on the fish composite-sample extracts according to the method described by Birke and Tillitt (2000). Use of quality control techniques, development of standard dose-response curves, and the establishment of toxic equivalents are detailed in Schmitt and others (2002).

\section{Gill EROD}

Gill cytochrome P4501A activity was measured as EROD by modifying the method of Jonsson and others (2002). Gill EROD may be more sensitive to low concentrations of water-borne planar hydrocarbon contaminants than liver EROD (Jonsson and others, 2006). Gill filaments were collected in two ways to determine which was optimal for field collections. For half the fish, whole gill arches were taken, two per fish, one arch from each side. Arches were placed inside tissue cassettes and immersed in a bottle containing ice-cold HEPES-Cortland (HC) buffer $(0.38 \mathrm{~g}$ of $\mathrm{KCl}, 7.74 \mathrm{~g}$ of NaCl, $0.23 \mathrm{~g}$ of MgSO4-7H2O, $0.23 \mathrm{~g}$ of $\mathrm{CaCl}_{2}-2 \mathrm{H}_{2} \mathrm{O}, 0.41 \mathrm{~g}$ of $\mathrm{NaH}_{2} \mathrm{PO}_{4}-\mathrm{H}_{2} \mathrm{O}, 1.43 \mathrm{~g}$ of HEPES, and $1 \mathrm{~g}$ of glucose per $\mathrm{L}$ of dH2O; $\mathrm{pH}$ 7.7). For the remaining fish, filament tips approximately $2 \mathrm{~mm}$ long were clipped from the gill arches immediately above the septum and placed in vials containing ice-cold $\mathrm{HC}$ buffer, at a ratio of one vial per fish. Gill filaments and arches were maintained at $4{ }^{\circ} \mathrm{C}$ for 48 hours prior to processing. The 2-mm-long gill filament tips appeared healthier (bright pink to red, little to no mucus coating) than the filaments on the whole arches and were used for all assays. For each fish, 10 filament tips of 2-mm length were placed into each of two wells in a 12-well plate (CoStar, Corning \#3512) containing HC buffer and kept on ice.

Once all filaments were in the plates, the $\mathrm{HC}$ buffer was replaced with $0.5 \mathrm{~mL}$ of reaction buffer (HC buffer supplemented with $10^{-6} \mathrm{M}$ 7-ethoxyresorufin [the substrate for CYP1A, resorufin ethyl ether, Sigma] and $10^{-5} \mathrm{M}$ dicoumarol; both solutions were prepared from stocks made in DMSO). Filaments were pre-incubated with continuous shaking in the dark at room temperature (to reflect the temperature of the water from which the fish were collected). After $10 \mathrm{~min}$, the reaction buffer was discarded and replaced with $0.7 \mathrm{~mL}$ of fresh reaction buffer. Because all fish were assumed to have fairly low CYP1A activities, filaments were incubated for $50 \mathrm{~min}$, the longest time period described in Jonsson and others (2002) protocol, with $200-\mu \mathrm{L}$ aliquots removed after 30 and $50 \mathrm{~min}$. Aliquots were transferred to a 96 -well plate (FluoroNunc/LumiNunc white polystyrene plates, untreated). A resorufin (resorufin sodium salt, Sigma) stock solution (10 millimolar concentration in methanol) was used to prepare standard solutions in reaction buffer; these were run as a standard curve, in duplicate, on each plate along with duplicate wells of reaction buffer alone. Fluorescence was measured in a multi-well plate reader (Perkin Elmer Fusion) with $535 / 590 \mathrm{EX} / \mathrm{EM}$ filters. EROD activity was calculated as picomoles of resorufin per filament tip per minute using the following formula: (fluorescence signal of 50-min aliquot minus fluorescence signal of 30 -min aliquot) divided by $20 \mathrm{~min}$; multiplied by $0.0005 \mathrm{~L}$ (correction factor for initial $0.5-\mathrm{mL}$ volume in well); divided by the slope of the resorufin (pmol RR) standard curve; divided by the number of gill filament tips in the well; multiplied by $1,000 \mathrm{pmol} R \mathrm{RR} / \mathrm{nmol} \mathrm{RR}$ (converting fluorescence signal from nmol resorufin standard curve to pmol resorufin). 


\section{Fish Immune System Responses}

\section{Vitamins $\mathrm{C}$ and $\mathrm{E}$ (ascorbate and $\alpha$-tocopherol) Assay}

Vitamins $\mathrm{C}$ and $\mathrm{E}$ are known to be important antioxidants in fish as well as in mammals. Reduced levels of vitamin $\mathrm{C}$ can cause reproductive dysfunction in fish (Dabrowski and Ciereszko, 2001), while vitamin $\mathrm{E}$ is necessary for the immune system. Samples of liver were used to assess $\alpha$-tocopherol $(\alpha \mathrm{T})$ metabolism and long-term storage (White and others, 1993). Liver $\alpha$ T concentration was measured using a reverse-phase HPLC method coupled to a fluorescence detector. Ascorbate concentrations were also analyzed in fish liver. Total ascorbate was determined using the colorimetric method (Roe and Kuether, 1943), modified as in Dabrowski and Hinterleitner (1989).

\section{Thyroid Hormones (T3 and T4)}

The thyroid system in fish regulates many metabolic processes that are critical during embryonic growth, metamorphosis, and reproduction in adults. Disruption or modulation of thyroid function from environmental contaminants could severely compromise fitness and survival. A review of this potential (Zhou and others, 2000; Brown and others, 2004) has indicated that numerous environmental contaminants (including chlorinated hydrocarbons, PAHs, PCBs, pesticides, phenols, metals, and pharmaceuticals) are likely to impact thyroid function. Thyroid biomarkers serve as indicators of exposure and potential effects. Two important thyroid hormones, the tetra-iodinated form (T4), and the tri-iodinated form (T3), were measured in fish plasma using standard RIA or enzyme immunoassay procedures (Grau, 1987).

\section{Fish and Invertebrate Communities}

\section{Invertebrates Communities}

\section{Riffle Habitat}

Collections from riffle substrates were made using a modified Surber sampler following methods outlined by Moulton and others (2002). Each sample was taken from a 0.25-square meter area immediately upstream from the sampler. The area was disturbed by digging or shuffling to dislodge organisms to wash them downstream into the sampler. Five sub samples were collected in the same type of habitat to compose a single composite sample. These samples were rinsed and placed in a container with buffered formalin. Identification and enumeration were made by the National Water Quality Laboratory (NWQL), Denver, Colorado.

\section{Depositional Habitat}

Grab samplers, such as Ponar and Eckman, were used to collect the depositional sediments. Individual grab samples were composited in a decontaminated stainless-steel container. Each of the samples to be composited was taken within the same in-stream habitat type but at a distance sufficient for avoiding interference among samples. The bulk sediments collected for chemistry were homogenized and subsampled for invertebrates and placed in a sample jar with 10 percent neutral buffered (sodium phosphate) formalin for preservation. The invertebrates were identified and enumerated by the NWQL, Denver, Colo. 


\section{Depositional Zone Invertebrate Deformities}

The presence of mouthpart deformities in benthic species provides evidence of exposure and sublethal effects in the primary consumers of streamfood webs. Chironomid deformities were evaluated from benthic samples collected in depositional zones. Deformities were assessed on all individuals mounted as a routine part of sample identification and enumeration by using published methods for members of subfamily Tanypodinae and the family Chironomidae (Dermott, 1991; Dickman and others, 1992).

\section{Fish Communities}

Boat-based electrofishing was used to collect fish in the Charles River. Two separate passes, one along each bank, were made in the designated reach. Fish collected in the first pass were processed before the second electrofishing pass. The fishcommunity data for each pass were kept separate (Moulton and others, 2002).

\section{Results}

\section{Field Fish Health Assessment}

Twenty common carp, 20 largemouth bass, and 40 white suckers were collected in the study area. We were able to obtain 10 male and 10 female common carp and 12 male and 8 female largemouth bass. Twenty-nine of the 40 white suckers collected were female. Length, weight, and age for common carp, largemouth bass, and white sucker collected for this study are provided in table 5. The number, location, and type of lesions, anomalies, and parasites observed during the field health assessment of common carp, largemouth bass, and white suckers are provided in tables 6 and 7. The condition factor, calculated somatic indices, and health assessment index scores are provided in table 8.

\section{Sediment and Water Chemistry}

Organochlorine pesticide concentrations, total PCB concentrations, and PAH concentrations (ng/L) are provided in tables 9 and 10 for SPMD samples, and pesticide and hormone concentrations (ng/L) are reported in table 11 for POCIS samples. Total PCBs, organochlorine pesticides, PBDE, and PAH concentrations (ng/g dry weight) from sediment samples are reported in tables 12 and 13. Measured concentrations $(\mathrm{ng} / \mathrm{mL})$ of elements in filtered sediment pore water are provided in table 14 , and concentrations of total recoverable elements $(\mu \mathrm{g} / \mathrm{g}$ dry weight) in Charles River sediments are reported in table 15 .

\section{Fish Residue Chemistry}

To determine the concentration of PCBs, organochlorine pesticides, and inorganic contaminants, fish were composited by species and gender. Concentrations (ng/g wet weight) of PCBs and organochlorine pesticides are reported in table 16, and concentrations ( $\mu \mathrm{g} / \mathrm{g}$ dry weight) of inorganic contaminants are reported in table 17 . In addition to the mercury concentrations measured from composited samples, mercury also was measured in muscle tissue collected from largemouth bass (table 18). Individual white suckers were analyzed for concentration (ng/g wet weight) of total PCBs and organochlorine pesticides (table 19). PAH metabolite concentrations ( $\mu \mathrm{g} / \mathrm{mL})$ associated with the bile of common carp, largemouth bass, and white sucker are provided in table 20. Concentrations of organochlorines, PBDEs, and PCBs and other contaminants associated with plasma of common carp, largemouth bass, and white sucker are provided in tables 21 and 22. 


\section{Toxicity of Sediments and Extracts from SPMD and POCIS Samplers}

Information on the survival and growth of the amphipod Hyalella azteca and the midge Chironomus dilutus after being exposed to sediment extracts are provided in table 23 . The Microtox ${ }^{\circledR}$ acute toxicity screen and the yeast estrogen screen (YES) were conducted on sediment and passive sampler extracts. Table 24 provides a comparison between controls and the potential toxicity of extracts from SPMDs and POCISs using the Microtox ${ }^{\circledR}$ bioassay and the YES bioassay.

\section{Fish Health Biomarkers and Indicators of Chemical Exposure}

Reproductive biomarkers associated with common carp, largemouth bass, and white sucker are provided in tables 25 through 27. Biomarkers associated with histological examination of tissues are provided in tables 28 and 29. Results from comet assay measurements taken on blood and liver cells collected from common carp and white suckers are reported in table 30. H4IIE bioassay-derived 2,3,7,8tetrachlorodibenzo-p-dioxin equivalents (TCDD-EQ) and cytochrome P4501A enzyme activity measured as EROD activity in liver and in gill filament tips from white suckers, common carp, and largemouth bass are reported in tables 31 through 33. Concentration of vitamin $C$ (ascorbic acid and vitamin $E(\alpha-$ tocopherol), as measured in liver tissue from common carp and white suckers, are reported in table 34.

Fifty-nine bacterial cultures obtained from 8 largemouth bass, 13 common carp, and 9 white suckers were isolated and investigated biochemically. The majority of these were motile aeromonas bacteria, which are commonly found in water. None of the listed bacterial pathogens were identified. Kidney tissues also were assayed for Renibacterium salmoninarum, the causative agent for bacterial kidney disease (BKD). As is often the case with running this test on non-salmonids, the preliminary ELISA test was positive for the presence of a component of this bacterium; however, the collaboratively run specific DNA-based test (polymerase chain reaction [PCR]) was negative, so the BKD status of these fish were determined to be negative.

\section{Fish and Invertebrate Communities}

Invertebrate diversity and abundance associated with depositional habitats are presented in table 35 . Chironomid species collected from these samples were evaluated for contaminant related head capsule deformities. All of the 68 specimens examined had structural symmetry and none of the typical deformities associated with chemical contamination. The NAWQA Program has previously collected information on invertebrates from riffle areas in the Charles River near Laundry Brook (NAWQA Station 01104615) during the course of their ongoing studies. The last two years in which data were collected from this site were 2002 and 2003. Results from these efforts are provided in table 36. Fish were also collected from NAWQA Station 01095220 as part of our study and as part of the NAWQA Program's study protocols (table 37). 
Table 5. Gender, body weight, length, and age of fish collected from the Charles River sorted by species and gender. (g, grams; mm, millimeters)

\begin{tabular}{|c|c|c|c|c|c|c|}
\hline Species & Gender & Fish ID & Collection date & $\begin{array}{c}\text { Body } \\
\text { weight }(g)\end{array}$ & $\begin{array}{l}\text { Body } \\
\text { length } \\
(\mathrm{mm})\end{array}$ & $\begin{array}{c}\text { Age } \\
\text { (years) }\end{array}$ \\
\hline Common carp & $\mathrm{F}$ & $\mathrm{CCO} 3$ & $8 / 23 / 2005$ & 4,095 & 646 & 4 \\
\hline Common carp & $\mathrm{F}$ & $\mathrm{CC} 04$ & $8 / 23 / 2005$ & 4,625 & 678 & 8 \\
\hline Common carp & $\mathrm{F}$ & $\mathrm{CC} 06$ & $8 / 23 / 2005$ & 3,245 & 612 & 7 \\
\hline Common carp & $\mathrm{F}$ & $\mathrm{CC} 07$ & $8 / 23 / 2005$ & 4,195 & 665 & 5 \\
\hline Common carp & $\mathrm{F}$ & $\mathrm{CC} 09$ & $8 / 23 / 2005$ & 6,045 & 648 & 6 \\
\hline Common carp & $\mathrm{F}$ & $\mathrm{CC} 16$ & $8 / 24 / 2005$ & 4,860 & 644 & 7 \\
\hline Common carp & $\mathrm{F}$ & $\mathrm{CC} 17$ & $8 / 24 / 2005$ & 3,905 & 678 & 3 \\
\hline Common carp & $\mathrm{F}$ & $\mathrm{CC} 18$ & $8 / 24 / 2005$ & 3,665 & 637 & 6 \\
\hline Common carp & $\mathrm{F}$ & CC19 & $8 / 24 / 2005$ & 1,725 & 475 & 5 \\
\hline Common carp & $\mathrm{F}$ & $\mathrm{CC} 20$ & $8 / 24 / 2005$ & 3,200 & 595 & 7 \\
\hline Common carp & M & $\mathrm{CC} 01$ & $8 / 23 / 2005$ & 2,685 & 573 & 3 \\
\hline Common carp & M & $\mathrm{CC} 02$ & $8 / 23 / 2005$ & 4,145 & 652 & 4 \\
\hline Common carp & M & $\mathrm{CC} 05$ & $8 / 23 / 2005$ & 3,955 & 635 & 3 \\
\hline Common carp & M & $\mathrm{CC} 08$ & $8 / 23 / 2005$ & 3,315 & 595 & 3 \\
\hline Common carp & M & $\mathrm{CC} 10$ & $8 / 23 / 2005$ & 4,920 & 682 & 6 \\
\hline Common carp & M & $\mathrm{CC} 11$ & $8 / 23 / 2005$ & 3,890 & 660 & 7 \\
\hline Common carp & M & $\mathrm{CC} 12$ & $8 / 23 / 2005$ & 3,915 & 645 & 4 \\
\hline Common carp & M & $\mathrm{CC} 13$ & $8 / 23 / 2005$ & 4,485 & 651 & 6 \\
\hline Common carp & M & $\mathrm{CC} 14$ & $8 / 23 / 2005$ & 3,125 & 586 & 3 \\
\hline Common carp & M & $\mathrm{CC} 15$ & $8 / 23 / 2005$ & 5,555 & 699 & 7 \\
\hline Largemouth bass & $\mathrm{F}$ & LMB01 & $8 / 23 / 2005$ & 1,610 & 457 & 14 \\
\hline Largemouth bass & $\mathrm{F}$ & LMB02 & $8 / 23 / 2005$ & 710 & 363 & 6 \\
\hline Largemouth bass & $\mathrm{F}$ & LMB03 & $8 / 23 / 2005$ & 1,360 & 462 & 10 \\
\hline Largemouth bass & $\mathrm{F}$ & LMB07 & $8 / 23 / 2005$ & 225 & 257 & 2 \\
\hline Largemouth bass & $\mathrm{F}$ & LMB11 & $8 / 24 / 2005$ & 465 & 322 & 3 \\
\hline Largemouth bass & $\mathrm{F}$ & LMB12 & $8 / 24 / 2005$ & 1,285 & 432 & 9 \\
\hline Largemouth bass & $\mathrm{F}$ & LMB14 & $8 / 24 / 2005$ & 705 & 355 & 3 \\
\hline Largemouth bass & $\mathrm{F}$ & LMB16 & $8 / 24 / 2005$ & 1,040 & 415 & 5 \\
\hline Largemouth bass & M & LMB04 & $8 / 23 / 2005$ & 835 & 396 & 13 \\
\hline Largemouth bass & M & LMB05 & $8 / 23 / 2005$ & 595 & 347 & 4 \\
\hline Largemouth bass & M & LMB06 & $8 / 23 / 2005$ & 245 & 259 & 2 \\
\hline Largemouth bass & M & LMB08 & $8 / 23 / 2005$ & 375 & 297 & 3 \\
\hline
\end{tabular}


Table 5. Gender, body weight, length, and age of fish collected from the Charles River sorted by species and gender. (g, grams; mm, millimeters) —Continued

\begin{tabular}{|c|c|c|c|c|c|c|}
\hline Species & Gender & Fish ID & Collection date & $\begin{array}{c}\text { Body } \\
\text { weight }(g)\end{array}$ & $\begin{array}{l}\text { Body } \\
\text { length } \\
(\mathrm{mm})\end{array}$ & $\begin{array}{c}\text { Age } \\
\text { (years) }\end{array}$ \\
\hline Largemouth bass & M & LMB09 & $8 / 23 / 2005$ & 295 & 277 & 2 \\
\hline Largemouth bass & M & LMB10 & $8 / 24 / 2005$ & 1,275 & 427 & 6 \\
\hline Largemouth bass & M & LMB13 & $8 / 24 / 2005$ & 685 & 369 & 5 \\
\hline Largemouth bass & M & LMB15 & $8 / 24 / 2005$ & 740 & 391 & 5 \\
\hline Largemouth bass & M & LMB17 & $8 / 24 / 2005$ & 605 & 344 & 6 \\
\hline Largemouth bass & M & LMB18 & $8 / 24 / 2005$ & 320 & 293 & 4 \\
\hline Largemouth bass & M & LMB19 & $8 / 24 / 2005$ & 530 & 334 & 2 \\
\hline Largemouth bass & M & LMB20 & $8 / 24 / 2005$ & 445 & 315 & 4 \\
\hline White sucker & $\mathrm{F}$ & WS01 & $8 / 23 / 2005$ & 1,201 & 494 & 15 \\
\hline White sucker & $\mathrm{F}$ & WS02 & $8 / 23 / 2005$ & 1,455 & 518 & 17 \\
\hline White sucker & $\mathrm{F}$ & WS03 & $8 / 23 / 2005$ & 1,460 & 519 & 16 \\
\hline White sucker & $\mathrm{F}$ & WS04 & $8 / 23 / 2005$ & 1,405 & 527 & 15 \\
\hline White sucker & $\mathrm{F}$ & WS05 & $8 / 23 / 2005$ & 1,145 & 488 & 9 \\
\hline White sucker & $\mathrm{F}$ & WS06 & $8 / 23 / 2005$ & 1,395 & 519 & 14 \\
\hline White sucker & $\mathrm{F}$ & WS07 & $8 / 23 / 2005$ & 1,320 & 516 & 13 \\
\hline White sucker & $\mathrm{F}$ & WS08 & $8 / 24 / 2005$ & 1,105 & 475 & 9 \\
\hline White sucker & $\mathrm{F}$ & WS09 & $8 / 24 / 2005$ & 1,455 & 522 & 12 \\
\hline White sucker & $\mathrm{F}$ & WS10 & $8 / 24 / 2005$ & 885 & 422 & 7 \\
\hline White sucker & $\mathrm{F}$ & WS11 & $8 / 24 / 2005$ & 1,305 & 515 & 8 \\
\hline White sucker & $\mathrm{F}$ & WS12 & $8 / 24 / 2005$ & 1,030 & 448 & 7 \\
\hline White sucker & $\mathrm{F}$ & WS13 & $8 / 24 / 2005$ & 1,280 & 512 & 9 \\
\hline White sucker & $\mathrm{F}$ & WS14 & $8 / 24 / 2005$ & 1,175 & 491 & 10 \\
\hline White sucker & $\mathrm{F}$ & WS15 & $8 / 24 / 2005$ & 1,045 & 464 & 10 \\
\hline White sucker & $\mathrm{F}$ & WS17 & $8 / 24 / 2005$ & 1,340 & 497 & 6 \\
\hline White sucker & $\mathrm{F}$ & WS18 & $8 / 24 / 2005$ & 1,150 & 486 & 12 \\
\hline White sucker & $\mathrm{F}$ & WS19 & $8 / 24 / 2005$ & 1,045 & 486 & 9 \\
\hline White sucker & $\mathrm{F}$ & WS21 & $8 / 24 / 2005$ & 1,245 & 492 & 13 \\
\hline White sucker & $\mathrm{F}$ & WS24 & $8 / 24 / 2005$ & 1,005 & 469 & 6 \\
\hline White sucker & $\mathrm{F}$ & WS25 & $8 / 24 / 2005$ & 955 & 484 & 14 \\
\hline White sucker & $\mathrm{F}$ & WS26 & $8 / 24 / 2005$ & 745 & 406 & 5 \\
\hline White sucker & $\mathrm{F}$ & WS29 & $8 / 24 / 2005$ & 895 & 442 & 15 \\
\hline White sucker & $\mathrm{F}$ & WS30 & $8 / 24 / 2005$ & 1,470 & 518 & 15 \\
\hline
\end{tabular}


Table 5. Gender, body weight, length, and age of fish collected from the Charles River sorted by species and gender. (g, grams; mm, millimeters) —Continued

\begin{tabular}{lcccccc}
\hline Species & Gender & Fish ID & Collection date & $\begin{array}{c}\text { Body } \\
\text { weight (g) }\end{array}$ & $\begin{array}{c}\text { Body } \\
\text { length } \\
\text { (mm) }\end{array}$ & $\begin{array}{c}\text { Age } \\
\text { (years) }\end{array}$ \\
\hline White sucker & F & WS31 & $8 / 24 / 2005$ & 775 & 405 & 4 \\
White sucker & F & WS32 & $8 / 24 / 2005$ & 1,315 & 521 & 17 \\
White sucker & F & WS34 & $8 / 24 / 2005$ & 1,065 & 470 & 6 \\
White sucker & F & WS34 & $8 / 24 / 2005$ & 1,670 & 551 & 15 \\
White sucker & F & WS37 & $8 / 24 / 2005$ & 1,165 & 475 & 5 \\
White sucker & M & WS16 & $8 / 24 / 2005$ & 1,060 & 481 & 15 \\
White sucker & M & WS20 & $8 / 24 / 2005$ & 1,130 & 474 & 10 \\
White sucker & M & WS22 & $8 / 24 / 2005$ & 835 & 445 & 13 \\
White sucker & M & WS23 & $8 / 24 / 2005$ & 1,040 & 468 & 17 \\
White sucker & M & WS27 & $8 / 24 / 2005$ & 810 & 431 & 5 \\
White sucker & M & WS28 & $8 / 24 / 2005$ & 845 & 422 & 5 \\
White sucker & M & WS33 & $8 / 24 / 2005$ & 825 & 437 & 5 \\
White sucker & M & WS35 & $8 / 24 / 2005$ & 985 & 455 & 10 \\
White sucker & $\mathrm{M}$ & WS38 & $8 / 24 / 2005$ & 975 & 473 & 14 \\
White sucker & $\mathrm{M}$ & WS39 & $8 / 24 / 2005$ & 770 & 408 & 7 \\
White sucker & $\mathrm{M}$ & WS40 & $8 / 24 / 2005$ & 895 & 443 & 6 \\
\hline
\end{tabular}


Table 6. Location and number of fish with lesions, anomalies, and parasites observed during the field health assessment in common carp, largemouth bass, and white suckers from the Charles River (August, 2005). (n, total number of fish examined)

\begin{tabular}{|c|c|c|c|c|c|c|c|c|c|c|c|}
\hline \multirow[b]{2}{*}{ Species } & \multirow[b]{2}{*}{$n$} & \multicolumn{10}{|c|}{ Location and number of lesions, anomalies, and parasites on fish } \\
\hline & & Body & Eyes & Opercles & Gills & Fins & Liver & Gonads & Spleen & Kidney & $\begin{array}{l}\text { Peritoneal } \\
\text { cavity }\end{array}$ \\
\hline Common carp & 20 & 0 & 0 & 0 & 0 & 7 & 15 & 2 & 0 & 0 & 0 \\
\hline $\begin{array}{l}\text { Largemouth } \\
\text { bass }\end{array}$ & 20 & 1 & 0 & 0 & 4 & 14 & 7 & 3 & 2 & 2 & 9 \\
\hline White sucker & 40 & 4 & 1 & 3 & 3 & 10 & 7 & 2 & 1 & 3 & 2 \\
\hline
\end{tabular}


Table 7. Types of lesions and anomalies and their frequency of detection in common carp, largemouth bass, and white suckers from the Charles River (August, 2005). The body surface, eyes, opercula, gills, fins, liver, gonad, spleen, and kidney of each fish were examined during the health assessment for the presence of lesions, parasites, and anomalies.

\begin{tabular}{|c|c|c|c|}
\hline \multirow{2}{*}{ Lesions and anomalies } & \multicolumn{3}{|c|}{ Frequency of detection } \\
\hline & Common carp & Largemouth bass & White sucker \\
\hline \multicolumn{4}{|l|}{ Body surface (skin) } \\
\hline Lesions & 0 & 1 & 1 \\
\hline Focal discoloration & 0 & 0 & 1 \\
\hline Scale anomalies & 0 & 0 & 2 \\
\hline \multicolumn{4}{|l|}{ Eyes } \\
\hline Exophthalmia & 0 & 0 & 1 \\
\hline \multicolumn{4}{|l|}{ Opercula } \\
\hline Slight shortening & 0 & 0 & 2 \\
\hline Severe shortening & 0 & 0 & 1 \\
\hline \multicolumn{4}{|l|}{ Gills } \\
\hline Frayed, ragged appearance & 0 & 0 & 1 \\
\hline Pale, very light color & 0 & 1 & 2 \\
\hline Parasites & 0 & 3 & 1 \\
\hline \multicolumn{4}{|l|}{ Fins } \\
\hline Frayed & 5 & 12 & 4 \\
\hline Mild erosion & 0 & 4 & 1 \\
\hline Sever erosion & 1 & 1 & 1 \\
\hline Deformed/damaged rays & 5 & 1 & 3 \\
\hline Nodules & 0 & 0 & 1 \\
\hline \multicolumn{4}{|l|}{ Liver } \\
\hline "Fatty liver" & 13 & 0 & 7 \\
\hline Focal discoloration & 0 & 5 & 0 \\
\hline Nodules & 0 & 2 & 0 \\
\hline Parasites & 2 & 3 & 1 \\
\hline \multicolumn{4}{|l|}{ Gonads } \\
\hline Asymmetric & 1 & 0 & 0 \\
\hline Egg adhesions & 1 & 0 & 0 \\
\hline Parasites & 0 & 3 & 2 \\
\hline \multicolumn{4}{|l|}{ Spleen } \\
\hline Granular & 0 & 1 & 0 \\
\hline Nodular & 0 & 1 & 0 \\
\hline Enlarged & 0 & 0 & 1 \\
\hline \multicolumn{4}{|l|}{ Kidney } \\
\hline Swollen & 0 & 0 & 2 \\
\hline Mottled & 0 & 1 & 0 \\
\hline Granular & 0 & 1 & 1 \\
\hline \multicolumn{4}{|l|}{ Peritoneal cavity } \\
\hline Mesenteric nodules $\backslash c y s t s$ & 0 & 2 & 0 \\
\hline Parasites & 0 & 9 & 2 \\
\hline
\end{tabular}


Table 8. Organosomatic indices, condition factor, and health assessment index (HAl) for common carp, largemouth bass, and white suckers collected from the Charles River (August, 2005). (ND, not determined)

\begin{tabular}{|c|c|c|c|c|c|c|}
\hline \multirow{2}{*}{ Species } & \multirow{2}{*}{ Fish ID } & \multicolumn{3}{|c|}{ Organosomatic indices 1} & \multirow{2}{*}{$\begin{array}{l}\text { Condition } \\
\text { factor }\end{array}$} & \multirow{2}{*}{$\mathrm{HAI}^{2}$} \\
\hline & & $\begin{array}{l}\text { Hepatosomatic index } \\
\text { (HSI) }\end{array}$ & $\begin{array}{c}\text { Gonadosomatic } \\
\text { index (GSI) }\end{array}$ & $\begin{array}{l}\text { Splenosomatic index } \\
\text { (SSI) }\end{array}$ & & \\
\hline Common carp & $\mathrm{CC} 01$ & ND & 4.57 & 0.24 & 1.43 & 0 \\
\hline Common carp & $\mathrm{CC} 02$ & ND & 7.17 & .21 & 1.50 & 30 \\
\hline Common carp & $\mathrm{CC} 03$ & ND & 3.53 & .17 & 1.52 & 10 \\
\hline Common carp & $\mathrm{CC} 04$ & ND & 3.35 & .15 & 1.48 & 10 \\
\hline Common carp & $\mathrm{CC} 05$ & ND & 3.82 & .16 & 1.54 & 0 \\
\hline Common carp & $\mathrm{CC} 06$ & ND & 7.09 & .14 & 1.42 & 30 \\
\hline Common carp & $\mathrm{CC} 07$ & ND & 6.45 & .15 & 1.43 & 30 \\
\hline Common carp & $\mathrm{CC} 08$ & ND & 3.47 & .21 & 1.57 & 30 \\
\hline Common carp & $\mathrm{CC} 09$ & ND & 14.14 & .15 & 2.22 & 40 \\
\hline Common carp & $\mathrm{CC} 10$ & ND & 5.10 & .14 & 1.55 & 30 \\
\hline Common carp & $\mathrm{CC} 11$ & ND & 7.19 & .17 & 1.35 & 70 \\
\hline Common carp & $\mathrm{CC} 12$ & ND & 6.69 & .25 & 1.46 & 30 \\
\hline Common carp & $\mathrm{CC} 13$ & ND & 5.00 & .15 & 1.63 & 30 \\
\hline Common carp & $\mathrm{CC} 14$ & ND & 3.62 & .11 & 1.55 & 30 \\
\hline Common carp & $\mathrm{CC} 15$ & ND & 4.71 & .18 & 1.63 & 40 \\
\hline Common carp & $\mathrm{CC} 16$ & ND & 7.07 & .18 & 1.82 & 30 \\
\hline Common carp & $\mathrm{CC} 17$ & ND & 4.71 & .12 & 1.25 & 30 \\
\hline Common carp & $\mathrm{CC} 18$ & ND & 4.33 & .14 & 1.42 & 10 \\
\hline Common carp & $\mathrm{CC} 19$ & ND & 12.37 & .09 & 1.61 & 30 \\
\hline Common carp & $\mathrm{CC} 20$ & ND & 4.79 & .17 & 1.52 & 30 \\
\hline Largemouth bass & LMB01 & 0.57 & .70 & .13 & 1.69 & 10 \\
\hline Largemouth bass & LMB02 & 0.86 & .75 & .06 & 1.48 & 0 \\
\hline Largemouth bass & LMB03 & 0.70 & .85 & .08 & 1.38 & 30 \\
\hline Largemouth bass & LMB04 & 0.69 & .13 & .20 & 1.34 & 10 \\
\hline Largemouth bass & LMB05 & 0.80 & .11 & .21 & 1.42 & 100 \\
\hline
\end{tabular}


Table 8. Organosomatic indices, condition factor, and health assessment index (HAl) for common carp, largemouth bass, and white suckers collected from the Charles River (August, 2005). (ND, not determined)_Continued

\begin{tabular}{|c|c|c|c|c|c|c|}
\hline \multirow{2}{*}{ Species } & \multirow{2}{*}{ Fish ID } & \multicolumn{3}{|c|}{ Organosomatic indices 1} & \multirow{2}{*}{$\begin{array}{l}\text { Condition } \\
\text { factor }\end{array}$} & \multirow{2}{*}{$\mathrm{HAl}^{2}$} \\
\hline & & $\begin{array}{l}\text { Hepatosomatic index } \\
\text { (HSI) }\end{array}$ & $\begin{array}{c}\text { Gonadosomatic } \\
\text { index (GSI) }\end{array}$ & $\begin{array}{c}\text { Splenosomatic index } \\
\text { (SSI) }\end{array}$ & & \\
\hline Largemouth bass & LMB06 & 0.71 & .07 & .07 & 1.41 & 0 \\
\hline Largemouth bass & LMB07 & 0.91 & .50 & .30 & 1.33 & 0 \\
\hline Largemouth bass & LMB08 & .76 & .07 & .06 & 1.43 & 0 \\
\hline Largemouth bass & LMB09 & .66 & .10 & .08 & 1.39 & 10 \\
\hline Largemouth bass & LMB10 & .81 & .15 & .08 & 1.64 & 10 \\
\hline Largemouth bass & LMB11 & 1.04 & .52 & .11 & 1.39 & 0 \\
\hline Largemouth bass & LMB12 & .74 & .77 & .09 & 1.59 & 10 \\
\hline Largemouth bass & LMB13 & .79 & .06 & .08 & 1.36 & 10 \\
\hline Largemouth bass & LMB14 & .84 & .60 & .10 & 1.58 & 10 \\
\hline Largemouth bass & LMB15 & 1.38 & .17 & .11 & 1.24 & 40 \\
\hline Largemouth bass & LMB16 & .64 & .65 & .08 & 1.46 & 40 \\
\hline Largemouth bass & LMB17 & .77 & .06 & .13 & 1.49 & 10 \\
\hline Largemouth bass & LMB18 & .76 & .04 & .27 & 1.27 & 0 \\
\hline Largemouth bass & LMB19 & .61 & .08 & .11 & 1.42 & 10 \\
\hline Largemouth bass & LMB20 & .85 & .04 & .05 & 1.42 & 20 \\
\hline White sucker & WS01 & ND & 2.45 & .17 & 1.00 & 0 \\
\hline White sucker & WS02 & ND & 1.54 & .07 & 1.05 & 100 \\
\hline White sucker & WS03 & ND & 1.70 & .09 & 1.04 & 30 \\
\hline White sucker & WS04 & ND & 2.07 & .23 & .96 & 60 \\
\hline White sucker & WS05 & ND & .35 & .21 & .99 & 10 \\
\hline White sucker & WS06 & ND & 1.63 & .08 & 1.00 & 10 \\
\hline White sucker & WS07 & ND & 2.01 & .15 & .96 & 60 \\
\hline White sucker & WS08 & ND & 2.42 & .16 & 1.03 & 30 \\
\hline White sucker & WS09 & ND & 2.22 & .20 & 1.02 & 0 \\
\hline White sucker & WS10 & ND & 2.42 & .14 & 1.18 & 100 \\
\hline White sucker & WS11 & ND & 3.55 & .15 & .96 & 0 \\
\hline
\end{tabular}


Table 8. Organosomatic indices, condition factor, and health assessment index (HAl) for common carp, largemouth bass, and white suckers collected from the Charles River (August, 2005). (ND, not determined)_Continued

\begin{tabular}{|c|c|c|c|c|c|c|}
\hline \multirow{2}{*}{ Species } & \multirow{2}{*}{ Fish ID } & \multicolumn{3}{|c|}{ Organosomatic indices ${ }^{1}$} & \multirow{2}{*}{$\begin{array}{l}\text { Condition } \\
\text { factor }\end{array}$} & \multirow{2}{*}{ HAI } \\
\hline & & $\begin{array}{c}\text { Hepatosomatic index } \\
\text { (HSI) }\end{array}$ & $\begin{array}{c}\text { Gonadosomatic } \\
\text { index (GSI) }\end{array}$ & $\begin{array}{c}\text { Splenosomatic index } \\
\text { (SSI) }\end{array}$ & & \\
\hline White sucker & WS12 & ND & 2.33 & .07 & 1.15 & 30 \\
\hline White sucker & WS13 & ND & 2.66 & .19 & .95 & 0 \\
\hline White sucker & WS14 & ND & 3.54 & .18 & .99 & 30 \\
\hline White sucker & WS15 & ND & 2.92 & .29 & 1.05 & 0 \\
\hline White sucker & WS16 & ND & .71 & .19 & .95 & 10 \\
\hline White sucker & WS17 & ND & 2.68 & .23 & 1.09 & 0 \\
\hline White sucker & WS18 & ND & 2.80 & .24 & 1.00 & 0 \\
\hline White sucker & WS19 & ND & 2.88 & .12 & .91 & 30 \\
\hline White sucker & WS20 & ND & 1.74 & .14 & 1.06 & 0 \\
\hline White sucker & WS21 & ND & 2.24 & .13 & 1.05 & 0 \\
\hline White sucker & WS22 & ND & .76 & .20 & .95 & 0 \\
\hline White sucker & WS23 & ND & 1.54 & .26 & 1.01 & 10 \\
\hline White sucker & WS24 & ND & 2.20 & .22 & .97 & 40 \\
\hline White sucker & WS25 & ND & 2.74 & .26 & .84 & 0 \\
\hline White sucker & WS26 & ND & 2.63 & .17 & 1.11 & 0 \\
\hline White sucker & WS27 & ND & 1.58 & .23 & 1.01 & 0 \\
\hline White sucker & WS28 & ND & .64 & .23 & 1.12 & 10 \\
\hline White sucker & WS29 & ND & 2.38 & .24 & 1.04 & 0 \\
\hline White sucker & WS30 & ND & 1.92 & .23 & 1.06 & 0 \\
\hline White sucker & WS31 & ND & 2.51 & .17 & 1.17 & 10 \\
\hline White sucker & WS32 & ND & 3.16 & .12 & .93 & 30 \\
\hline White sucker & WS33 & ND & 1.16 & .27 & .99 & 0 \\
\hline White sucker & WS34 & ND & 1.58 & .13 & 1.03 & 0 \\
\hline White sucker & WS35 & ND & 2.07 & .29 & 1.05 & 0 \\
\hline White sucker & WS36 & ND & 3.70 & .15 & 1.00 & 0 \\
\hline White sucker & WS37 & ND & 1.60 & .18 & 1.09 & 10 \\
\hline
\end{tabular}


Table 8. Organosomatic indices, condition factor, and health assessment index (HAl) for common carp, largemouth bass, and white suckers collected from the Charles River (August, 2005). (ND, not determined)_Continued

\begin{tabular}{lllcccc}
\hline \multirow{2}{*}{ Species } & \multirow{2}{*}{ Fish ID } & \multicolumn{3}{c}{ Organosomatic indices $^{1}$} & \multicolumn{2}{c}{$\begin{array}{c}\text { Condition } \\
\text { factor }\end{array}$} \\
\cline { 3 - 6 } & & $\begin{array}{c}\text { Hepatosomatic index } \\
\text { (HSI) }\end{array}$ & $\begin{array}{c}\text { Gonadosomatic } \\
\text { index (GSI) }\end{array}$ & $\begin{array}{c}\text { Splenosomatic index } \\
\text { (SSI) }\end{array}$ & HAI $^{2}$ \\
\hline White sucker & WS38 & ND & 2.21 & .18 & .92 & 10 \\
White sucker & WS39 & ND & .49 & .11 & 1.13 & 0 \\
White sucker & WS40 & ND & 1.18 & .22 & 1.03 & 30 \\
\hline
\end{tabular}

${ }^{1}$ The Organosomatic index scores were calculated by dividing an organ's weight by the fish's body weight. Somatic indices were calculated for the liver (HSI), gonads (GSI), and spleen (SSI). HSI was only calculated only for fish species (largemouth bass) that have a discreet liver.

${ }^{2}$ Numerical values were assigned to internal and external observations of anomalies and lesions recorded in the field, and a necropsy-based fish HAI score was calculated for each fish by summing these values for all organs. 
Table 9. Organochlorine pesticide (OCP) and total polychlorinated biphenyl (PCB) analyte concentrations from semi-permeable membrane devices (SPMD) collected from the Charles River after 33 days of deployment (August, 2005). (ND, not determined; ng/SPMD, nanograms per SPMD; pg/L, picograms per liter; <, concentrations below the reporting limits; MDL, method detection limit; MQL, method quantitation limit)

\begin{tabular}{|c|c|c|c|c|c|c|}
\hline Analyte $^{1}$ & $\begin{array}{c}\mathrm{MDL}^{2} \\
\text { (ng/SPMD) }\end{array}$ & $\begin{array}{c}M^{M L^{3}} \\
\text { (ng/SPMD) }\end{array}$ & $\begin{array}{l}\text { Replicate \#1 } \\
\text { (ng/SPMD) }\end{array}$ & $\begin{array}{l}\text { Replicate \#2 } \\
\text { (ng/SPMD) }\end{array}$ & $\begin{array}{c}\text { Mean } \\
\text { (ng/SPMD) }\end{array}$ & $\begin{array}{c}\text { Mean aqueous } \\
\text { concentration } \\
(\mathrm{pg} / \mathrm{L})\end{array}$ \\
\hline Trifluralin & 0.05 & 0.25 & 0.42 & 0.35 & 0.39 & ND \\
\hline Hexachlorobenzene & .18 & .47 & 13.00 & 14.00 & 14.00 & 96 \\
\hline Pentachloroanisole & .20 & 1.00 & 58.00 & 72.00 & 65.00 & 240 \\
\hline$\alpha-\mathrm{BHC}$ & 3.20 & 9.50 & $<9.50$ & $<9.50$ & $<9.50$ & ND \\
\hline Diazinon & 5.80 & 17.00 & $<5.80$ & 25.00 & $<17.00$ & ND \\
\hline Lindane & 3.50 & 6.60 & $<3.50$ & $<3.50$ & $<3.50$ & ND \\
\hline$\beta-\mathrm{BHC}$ & .20 & 1.00 & 1.30 & 1.80 & 1.50 & 46 \\
\hline Heptachlor & .20 & 1.00 & $<.20$ & $<.20$ & $<.20$ & ND \\
\hline$\delta$-BHC & 5.90 & 16.00 & $<5.90$ & $<5.90$ & $<5.90$ & ND \\
\hline Dacthal & .30 & .89 & 24.00 & 26.00 & 25.00 & 650 \\
\hline Chlorpyrifos & .23 & .67 & $<.23$ & $<.23$ & $<.23$ & ND \\
\hline Oxychlordane & .89 & 4.30 & 20.00 & 23.00 & 21.00 & 150 \\
\hline Heptachlor epoxide & .46 & 1.10 & 26.00 & 28.00 & 27.00 & 270 \\
\hline trans-Chlordane & 1.20 & 2.50 & 87.00 & 98.00 & 93.00 & 540 \\
\hline trans-Nonachlor & .20 & 1.00 & 56.00 & 63.00 & 59.00 & 360 \\
\hline$o, p^{\prime}-\mathrm{DDE}$ & .20 & 1.00 & $<.20$ & $<.20$ & $<.20$ & ND \\
\hline cis-Chlordane & 1.20 & 3.00 & 150.00 & 170.00 & 160.00 & 880 \\
\hline Endosulfan & .20 & 1.00 & $<.20$ & $<.20$ & $<.20$ & ND \\
\hline$p, p^{\prime}-\mathrm{DDE}$ & 5.10 & 9.20 & 52.00 & 62.00 & 57.00 & 210 \\
\hline Dieldrin & 3.40 & 9.10 & 62.00 & 66.00 & 64.00 & 380 \\
\hline$o, p^{\prime}-\mathrm{DDD}$ & 6.50 & 17.00 & 32.00 & 37.00 & 34.00 & 230 \\
\hline Endrin & 3.30 & 8.90 & $<3.30$ & $<3.30$ & $<3.30$ & ND \\
\hline cis-Nonachlor & 2.30 & 6.40 & 23.00 & 25.00 & 24.00 & 180 \\
\hline$o, p^{\prime}-\mathrm{DDT}$ & .20 & 1.00 & 12.00 & 14.00 & 13.00 & 150 \\
\hline
\end{tabular}


Table 9. Organochlorine pesticide (OCP) and total polychlorinated biphenyl (PCB) analyte concentrations from semi-permeable membrane devices (SPMD) collected from the Charles River after 33 days of deployment (August, 2005). (ND, not determined; ng/SPMD, nanograms per SPMD; pg/L, picograms per liter; <, concentrations below the reporting limits; MDL, method detection limit; MQL, method quantitation limit) -Continued

\begin{tabular}{|c|c|c|c|c|c|c|}
\hline Analyte 1 & $\begin{array}{c}\text { MDL2 }^{2} \\
\text { (ng/SPMD) }\end{array}$ & $\begin{array}{c}\mathrm{MQL}^{3} \\
\text { (ng/SPMD) }\end{array}$ & $\begin{array}{c}\text { Replicate \#1 } \\
\text { (ng/SPMD) }\end{array}$ & $\begin{array}{c}\text { Replicate \#2 } \\
\text { (ng/SPMD) }\end{array}$ & $\begin{array}{c}\text { Mean } \\
\text { (ng/SPMD) }\end{array}$ & $\begin{array}{c}\text { Mean aqueous } \\
\text { concentration } \\
\text { (pg/L) }\end{array}$ \\
\hline$p, p^{\prime}-\mathrm{DDD}$ & 5.60 & 15.00 & 70.00 & 79.00 & 74.00 & 440 \\
\hline Endosulfan-II & 1.20 & 2.10 & 43.00 & 48.00 & 46.00 & ND \\
\hline$p, p^{\prime}$-DDT & 1.40 & 1.90 & 51.00 & 59.00 & 55.00 & 520 \\
\hline Endosulfan Sulfate & .89 & 2.60 & 8.70 & 4.80 & 6.80 & ND \\
\hline Methoxychlor & 1.80 & 4.90 & 9.50 & 5.70 & 7.60 & 140 \\
\hline Mirex & .20 & 1.00 & $<.20$ & $<.20$ & $<.20$ & ND \\
\hline cis-Permethrin & 5.30 & 15.00 & $<5.30$ & $<5.30$ & $<5.30$ & ND \\
\hline trans-Permethrin & 340.00 & 930.00 & $<340.00$ & $<340.00$ & $<340.00$ & ND \\
\hline Total PCBs & 17.00 & 43.00 & 380.00 & 440.00 & 410.00 & 4,400 \\
\hline
\end{tabular}

${ }^{1}$ OCPs and total PCBs determined by dual-column, high-resolution capillary gas chromatography with electron-capture detector. Total PCB aqueous concentration was estimated based on a water temperature of $18^{\circ} \mathrm{C}$ due to the lack of replicate data at $26^{\circ} \mathrm{C}$. The actual concentration may have been somewhat greater due to increased sampling at increased temperatures. Pyrene- $d_{10}\left(k_{\text {eprc }}=0.014 \mathrm{~d}^{-1}\right)$ was used for the replicate adjustments.

${ }^{2} \mathrm{MDL}$ is defined as the mean of procedural field blanks plus three standard deviations of coincident peaks in field blanks (Keith, 1991).

${ }^{3} \mathrm{MQL}$ is defined as the mean of procedural field blanks plus ten standard deviations of coincident peaks in field blanks (Keith, 1991). 
Table 10. Polycyclic aromatic hydrocarbon (PAH) analyte concentrations from semi-permeable membrane devices (SPMDs) collected from the Charles River after 33 days of deployment (August, 2005). (ND, not determined; ng/SPMD, nanograms per SPMD; ng/L, nangrams per liter; <, concentrations below the reporting limits; MDL, method detection limit; MQL, method quantitation limit)

\begin{tabular}{|c|c|c|c|c|c|c|}
\hline Analyte ${ }^{1}$ & $\begin{array}{c}\mathrm{MDL}^{2} \\
\text { (ng/SPMD) }\end{array}$ & $\begin{array}{c}\mathrm{MQL}^{3} \\
\text { (ng/SPMD) }\end{array}$ & $\begin{array}{l}\text { Replicate \#1 } \\
\text { (ng/SPMD) }\end{array}$ & $\begin{array}{c}\text { Replicate \#2 } \\
\text { (ng/SPMD) }\end{array}$ & $\begin{array}{c}\text { Mean } \\
\text { (ng/SPMD) }\end{array}$ & $\begin{array}{c}\text { Mean aqueous } \\
\text { concentration } \\
\text { (ng/L) }\end{array}$ \\
\hline Naphthalene & 4 & 20 & $<4$ & $<4$ & $<4$ & ND \\
\hline Acenaphthylene & 4 & 20 & $<4$ & $<4$ & $<4$ & ND \\
\hline Acenaphthene & 4 & 20 & 90 & 150 & 120 & 1.40 \\
\hline Fluorene & 4 & 20 & 100 & 150 & 130 & .90 \\
\hline Phenanthrene & 26 & 76 & 1,300 & 1,500 & 1,400 & 11.00 \\
\hline Anthracene & 4 & 20 & 230 & 200 & 220 & 1.10 \\
\hline Fluoranthene & 26 & 76 & 8,800 & 9,800 & 9,300 & 67.00 \\
\hline Pyrene & 26 & 76 & 5,700 & 6,200 & 6,000 & 39.00 \\
\hline Benz[a]anthracene & 4 & 20 & 690 & 800 & 750 & 7.00 \\
\hline Chrysene & 4 & 20 & 3,500 & 3,700 & 3,600 & 25.00 \\
\hline Benzo[b]fluoranthene & 4 & 20 & 870 & 1,000 & 940 & 14.00 \\
\hline Benzo[k]fluoranthene & 4 & 20 & 680 & 820 & 750 & 6.30 \\
\hline Benzo[a]pyrene & 4 & 20 & 260 & 290 & 280 & 2.60 \\
\hline Indeno[1,2,3-c,d]pyrene & 26 & 76 & 170 & 180 & 180 & 1.90 \\
\hline Dibenz[a,h]anthracene & 26 & 76 & $<76$ & $<76$ & $<76$ & ND \\
\hline Benzo[g,h,i]perylene & 26 & 76 & 170 & 180 & 180 & 3.60 \\
\hline Benzo[b]thiophene & 4 & 20 & $<4$ & $<4$ & $<4$ & ND \\
\hline 2-Methylnaphthalene & 4 & 20 & $<4$ & $<20$ & $<20$ & ND \\
\hline 1-Methylnaphthalene & 4 & 20 & $<4$ & $<20$ & $<20$ & ND \\
\hline Biphenyl & 4 & 20 & $<4$ & $<4$ & $<4$ & ND \\
\hline 1-Ethylnaphthalene & 4 & 20 & $<4$ & $<4$ & $<4$ & ND \\
\hline 1,2-Dimethylnaphthalene & 240 & 680 & $<240$ & $<240$ & $<240$ & ND \\
\hline 4-Methylbiphenyl & 4 & 20 & $<4$ & $<4$ & $<4$ & ND \\
\hline
\end{tabular}


Table 10. Polycyclic aromatic hydrocarbon (PAH) analyte concentrations from semi-permeable membrane devices (SPMDs) collected from the Charles River after 33 days of deployment (August, 2005). (ND, not determined; ng/SPMD, nanograms per SPMD; ng/L, nangrams per liter; <, concentrations below the reporting limits; MDL, method detection limit; MQL, method quantitation limit)—Continued

\begin{tabular}{|c|c|c|c|c|c|c|}
\hline Analyte ${ }^{1}$ & $\begin{array}{c}\mathrm{MDL}^{2} \\
\text { (ng/SPMD) }\end{array}$ & $\begin{array}{c}M^{M L^{3}} \\
\text { (ng/SPMD) }\end{array}$ & $\begin{array}{c}\text { Replicate \#1 } \\
\text { (ng/SPMD) }\end{array}$ & $\begin{array}{c}\text { Replicate \#2 } \\
\text { (ng/SPMD) }\end{array}$ & $\begin{array}{c}\text { Mean } \\
\text { (ng/SPMD) }\end{array}$ & $\begin{array}{c}\text { Mean aqueous } \\
\text { concentration } \\
\text { (ng/L) }\end{array}$ \\
\hline 2,3,5-Trimethylnaphthalene & 4 & 20 & 70 & 70 & 70 & .62 \\
\hline 1-Methylfluorene & 26 & 76 & 90 & 110 & 100 & .93 \\
\hline Dibenzothiophene & 4 & 20 & 50 & 70 & 60 & .49 \\
\hline 2-Methylphenanthrene & 4 & 20 & 360 & 410 & 390 & 3.50 \\
\hline 3,6-Dimethylphenanthrene & 4 & 20 & 100 & 140 & 120 & 1.40 \\
\hline 2-Methylfluoranthene & 4 & 20 & 320 & 350 & 340 & 4.10 \\
\hline Benzo[b]naphtha-[2,1-d]thiophene & 4 & 20 & 440 & 460 & 450 & ND \\
\hline Benzo[e]pyrene & 4 & 20 & 700 & 710 & 710 & 19.00 \\
\hline Perylene & 4 & 20 & 70 & 90 & 80 & ND \\
\hline 3-Methylcholanthrene & 4 & 20 & $<4$ & $<4$ & $<4$ & ND \\
\hline
\end{tabular}

${ }^{1}$ Determined by dual-column, high-resolution, capillary gas chromatography with mass selective detector (GC-MSD).

${ }^{2} \mathrm{MDL}$ is defined as the mean of procedural field blanks plus three standard deviations of coincident peaks in field blanks (Keith, 1991).

${ }^{3} \mathrm{MQL}$ is defined as the mean of procedural field blanks plus ten standard deviations of coincident peaks in field blanks (Keith, 1991). 
Table 11. Pesticide and hormone concentrations from polar organic chemical integrative samplers (POCIS) collected from the Charles River after 33 days of deployment (August, 2005). (ND, not determined; ng/POCIS, nanograms per POCIS; ng/L, nanograms per liter; <, concentrations below the reporting limits; MDL, method detection limit; MQL, method quantitation limit)

\begin{tabular}{|c|c|c|c|c|c|c|}
\hline Analyte $^{1}$ & $\begin{array}{c}\mathrm{MDL}^{2} \\
\text { (ng/POCIS) }\end{array}$ & $\begin{array}{c}\mathrm{MQL}^{3} \\
\text { (ng/POCIS) }\end{array}$ & $\begin{array}{c}\text { Replicate \#1 } \\
\text { (ng/POCIS) }\end{array}$ & $\begin{array}{c}\text { Replicate \#2 } \\
\text { (ng/POCIS) }\end{array}$ & $\begin{array}{c}\text { Mean } \\
\text { (ng/POCIS) }\end{array}$ & $\begin{array}{c}\text { Mean aqueous } \\
\text { concentration } \\
(\mathrm{ng} / \mathrm{L}, \mathrm{n}=2)\end{array}$ \\
\hline \multicolumn{7}{|l|}{ Pesticides } \\
\hline Atrazine & 1 & 3 & $<1$ & $<1$ & $<1$ & ND \\
\hline Ametryn & 15 & 20 & $<15$ & $<15$ & $<15$ & ND \\
\hline Atraton & 33 & 57 & $<33$ & $<33$ & $<33$ & ND \\
\hline Metribuzin & 12 & 17 & $<12$ & $<12$ & $<12$ & ND \\
\hline Prometon & 23 & 47 & $<23$ & $<23$ & $<23$ & ND \\
\hline Prometryn & 19 & 23 & $<19$ & $<19$ & $<19$ & ND \\
\hline Propazine & 5 & 10 & $<5$ & $<10$ & $<10$ & ND \\
\hline Simazine & 3 & 17 & $<17$ & $<17$ & $<17$ & ND \\
\hline Simetryn & 15 & 20 & $<15$ & $<15$ & $<15$ & ND \\
\hline Terbuthylazine & 9 & 13 & $<13$ & $<13$ & $<13$ & ND \\
\hline Terbutryne & 22 & 27 & $<22$ & $<22$ & $<22$ & ND \\
\hline Desethylatrazine & 3 & 17 & $<3$ & $<3$ & $<3$ & ND \\
\hline Desisopropylatrazine & 7 & 33 & $<7$ & $<7$ & $<7$ & ND \\
\hline Acetochlor & 1 & 3 & $<1$ & $<1$ & $<1$ & ND \\
\hline Alachlor & 12 & 17 & $<12$ & $<12$ & $<12$ & ND \\
\hline Metolachlor & 15 & 20 & $<15$ & $<20$ & $<20$ & ND \\
\hline Chlorpyrifos & 1 & 3 & 13 & 13 & 13 & ND \\
\hline Diazinon & 12 & 17 & $<12$ & $<12$ & $<12$ & ND \\
\hline Fonofos & 12 & 17 & $<12$ & $<12$ & $<12$ & ND \\
\hline Malathion & 3 & 17 & $<3$ & $<3$ & $<3$ & ND \\
\hline Methyl Parathion & 1 & 3 & $<1$ & $<1$ & $<1$ & ND \\
\hline Dacthal & 5 & 10 & $<5$ & $<5$ & $<5$ & ND \\
\hline EPTC & 1 & 3 & $<1$ & $<1$ & $<1$ & ND \\
\hline Fipronil & 25 & 30 & $<25$ & $<25$ & $<25$ & ND \\
\hline Pendimethalin & 1 & 3 & 47 & 47 & 47 & 5.5 \\
\hline Trifluralin & 1 & 3 & 30 & 30 & 30 & ND \\
\hline \multicolumn{7}{|c|}{ Hormones- HPLC Method } \\
\hline $17 \beta$-Estradiol & 13 & 67 & $<13$ & $<13$ & $<13$ & ND \\
\hline $17 \alpha$-Ethynylestradiol & 13 & 67 & $<13$ & $<13$ & $<13$ & ND \\
\hline Estriol & ND & ND & ND & ND & ND & ND \\
\hline
\end{tabular}


Table 11. Pesticide and hormone concentrations from polar organic chemical integrative samplers (POCIS) collected from the Charles River after 33 days of deployment (August, 2005). (ND, not determined; ng/POCIS, nanograms per POCIS; ng/L, nanograms per liter; <, concentrations below the reporting limits; MDL, method detection limit; MQL, method quantitation limit)—Continued

\begin{tabular}{|c|c|c|c|c|c|c|}
\hline Analyte $^{1}$ & $\begin{array}{c}\mathrm{MDL}^{2} \\
\text { (ng/POCIS) }\end{array}$ & $\begin{array}{c}\mathrm{MQL}^{3} \\
\text { (ng/POCIS) }\end{array}$ & $\begin{array}{c}\text { Replicate \#1 } \\
\text { (ng/POCIS) }\end{array}$ & $\begin{array}{c}\text { Replicate \#2 } \\
\text { (ng/POCIS) }\end{array}$ & $\begin{array}{c}\text { Mean } \\
\text { (ng/POCIS) }\end{array}$ & $\begin{array}{l}\text { Mean aqueous } \\
\text { concentration } \\
\text { (ng/L, } n=2)\end{array}$ \\
\hline Estrone & 13 & 67 & $<13$ & $<13$ & $<13$ & ND \\
\hline \multicolumn{7}{|c|}{ Hormones- GC-MSD Method } \\
\hline $17 \beta$-Estradiol & 13 & 37 & $<13$ & $<13$ & $<13$ & ND \\
\hline $17 \alpha$-Ethynylestradiol & 13 & 37 & $<13$ & $<13$ & $<13$ & ND \\
\hline Estriol & 10 & 33 & $<10$ & $<10$ & $<10$ & ND \\
\hline Estrone & 13 & 37 & $<13$ & $<13$ & $<13$ & ND \\
\hline
\end{tabular}

${ }^{1}$ Pesticides determined by dual-column, high-resolution, capillary gas chromatography with mass selective detector (GC-MSD). Hormones determined by GCMSD and liquid chromatograph with diode array detector (HPLC).

${ }^{2} \mathrm{MDL}$ is defined as the mean of procedural field blanks plus three standard deviations of coincident peaks in field blanks (Keith, 1991).

${ }^{3} \mathrm{MQL}$ is defined as the mean of procedural field blanks plus ten standard deviations of coincident peaks in field blanks (Keith, 1991). 
Table 12. Analytes associated with total polychlorinated biphenyls (PCBs), organochlorine pesticides (OCPs), and polybrominated diphenyl ether (PBDE) concentrations (ng/g dry weight) from three sediment samples collected from the Charles River (August, 2005). (ND, not determined; ng/g, nanograms per gram; $<$, concentrations below the reporting limits)

\begin{tabular}{|c|c|c|c|c|c|}
\hline Analytes ${ }^{1}$ & $\begin{array}{c}\text { Method } \\
\text { detection } \\
\text { limit } 2\end{array}$ & $\begin{array}{c}\text { Method } \\
\text { quantitation } \\
\text { limit }^{3}\end{array}$ & Sample 1 & Sample 2 & Sample 3 \\
\hline Total PCBs & 68.00 & 74.00 & 110.00 & $3,400.00$ & $5,000.00$ \\
\hline Pentachloro-benzene & .20 & .29 & $<.20$ & .56 & .92 \\
\hline Hexachloro-benzene & .18 & .31 & .53 & .76 & 1.60 \\
\hline Pentachloro-anisole & .17 & .25 & .24 & .64 & .97 \\
\hline$\alpha-\mathrm{BHC}(\mathrm{a}-\mathrm{HCH})$ & .11 & .15 & $<.11$ & $<.11$ & $<.11$ \\
\hline$\beta-\mathrm{BHC}(\mathrm{b}-\mathrm{HCH})$ & .16 & .23 & 1.70 & 14.00 & 8.10 \\
\hline Lindane $(\mathrm{g}-\mathrm{HCH})$ & .11 & .16 & .13 & 1.80 & 1.00 \\
\hline$\delta-\mathrm{BHC}(\mathrm{d}-\mathrm{HCH})$ & .11 & .19 & $<.11$ & $<.11$ & $<.11$ \\
\hline Heptachlor & .14 & .19 & $<.14$ & $<.14$ & $<.14$ \\
\hline Heptachlor epoxide & .14 & .16 & $<.14$ & $<.14$ & $<.14$ \\
\hline Aldrin & .11 & .12 & $<.11$ & $<.11$ & $<.11$ \\
\hline Dacthal & .21 & .37 & $<.21$ & $<.21$ & $<.21$ \\
\hline Dieldrin & .13 & .17 & 3.10 & 11.00 & 3.10 \\
\hline Endrin & .14 & .19 & 1.90 & 5.70 & 4.10 \\
\hline Oxychlordane & .14 & .14 & $<.14$ & $<.14$ & $<.14$ \\
\hline cis-Chlordane & .17 & .26 & 10.00 & 97.00 & 34.00 \\
\hline trans-Chlordane & .31 & .64 & 11.00 & 122.00 & 54.00 \\
\hline cis-Nonachlor & .14 & 19 & 2.10 & 18.00 & 11.00 \\
\hline trans-Nonachlor & .15 & .20 & 7.30 & 46.00 & 18.00 \\
\hline$o, p^{\prime}-\mathrm{DDE}$ & .14 & .18 & $<.14$ & 20.00 & 10.00 \\
\hline$o, p^{\prime}-\mathrm{DDD}$ & .24 & .48 & 13.00 & 233.00 & 79.00 \\
\hline$o, p^{\prime}-\mathrm{DDT}$ & .19 & .36 & $<.19$ & $<.19$ & $<.19$ \\
\hline$p, p$ '-DDE & .13 & .18 & 9.10 & 240.00 & 130.00 \\
\hline$p, p$-DDD & .12 & .19 & 22.00 & $1,044.00$ & 330.00 \\
\hline$p, p$-DDT & .25 & .51 & 8.10 & 30.00 & 94.00 \\
\hline Endosulfan I & .16 & .25 & $<.16$ & $<.16$ & $<.16$ \\
\hline Endosulfan II & .16 & .25 & $<.16$ & $<.16$ & $<.16$ \\
\hline Endosulfate & .14 & .20 & $<.14$ & $<.14$ & $<.14$ \\
\hline Methoxychlor & .16 & .21 & $<.16$ & $<.16$ & $<.16$ \\
\hline Mirex & .21 & .30 & $<.21$ & 1.90 & .64 \\
\hline Toxaphene & 12.00 & 28.00 & 84.00 & 227.00 & 98.00 \\
\hline PBDE-28 & 2.10 & ND & $<2.10$ & $<2.10$ & $<2.10$ \\
\hline PBDE-47 & 2.70 & ND & $<2.70$ & $<2.70$ & $<2.70$ \\
\hline PBDE-85 & 3.20 & ND & $<3.20$ & $<3.20$ & $<3.20$ \\
\hline PBDE-66 & 3.40 & ND & $<3.40$ & $<3.40$ & $<3.40$ \\
\hline PBDE-99 & 4.60 & ND & $<4.60$ & $<4.60$ & 1.60 \\
\hline PBDE-100 & 5.50 & ND & $<5.50$ & $<5.50$ & $<5.50$ \\
\hline PBDE-153 & 3.90 & ND & $<3.90$ & $<3.90$ & $<3.90$ \\
\hline PBDE-154 & 5.70 & ND & $<5.70$ & $<5.70$ & $<5.70$ \\
\hline PBDE-183 & 4.10 & ND & $<4.10$ & $<4.10$ & $<4.10$ \\
\hline
\end{tabular}

${ }^{1} \mathrm{PCBs}$, OCPs, and PBDEs determined by dual-column, high-resolution capillary gas chromatography with electroncapture detector.

${ }^{2}$ Method detection limit (MDL) is defined as the mean of procedural field blanks plus three standard deviations of coincident peaks in field blanks (Keith, 1991).

${ }^{3}$ Method quantitation limit (MQL) is defined as the mean of procedural field blanks plus ten standard deviations of coincident peaks in field blanks (Keith, 1991). 
Table 13. Polycyclic Aromatic Hydrocarbon (PAH) analyte concentrations (ng/g dry weight) from three sediment samples collected from the Charles River (August, 2005). Priority PAH compounds are presented in bold text (Eisler, 1987). Sample 1 was divided prior to sample analysis into thirds $(1 \mathrm{~A}, 1 \mathrm{~B}$, and $1 \mathrm{C}$ ) because of the non-homogenous nature (stone material composition) of the sediment sample. (ng/g, nanograms per gram; $<$, concentrations below the reporting limits)

\begin{tabular}{|c|c|c|c|c|c|c|}
\hline Analyte $^{1}$ & $\begin{array}{c}\text { Field blank }{ }^{2} \\
(2.5 \mathrm{~g} \mathrm{EQ})\end{array}$ & $\begin{array}{l}\text { Sample 1A } \\
\text { (0.05 g EQ) }\end{array}$ & $\begin{array}{l}\text { Sample 1B } \\
\text { (0.05 g EQ) }\end{array}$ & $\begin{array}{l}\text { Sample 1C } \\
\text { (0.05 g EQ) }\end{array}$ & $\begin{array}{c}\text { Sample } 2 \\
\text { (0.05 g EQ) }\end{array}$ & $\begin{array}{c}\text { Sample } 3 \\
\text { (0.05 g EQ) }\end{array}$ \\
\hline Naphthalene & 5 & 340 & 130 & 1,200 & 1,700 & 970 \\
\hline 2-Methyl_Naphthalene & 13 & 130 & 78 & 360 & 1,100 & 1,100 \\
\hline 1-Methyl_Naphthalene & 7 & 63 & 55 & 240 & 650 & 760 \\
\hline Acenaphthylene & $<1$ & 110 & 41 & 170 & 180 & 160 \\
\hline Acenaphthene & $<1$ & 170 & 72 & 1,200 & 1,200 & 2,900 \\
\hline Fluorene & 1 & 440 & 130 & 1,100 & 1,600 & 2,900 \\
\hline Phenanthrene & 6 & 4,300 & 1,500 & 6,900 & 6,400 & 9,300 \\
\hline Anthracene & $<1$ & 2,250 & 220 & 2,400 & 3,300 & 4,400 \\
\hline 2-Methyl_Anthracene & $<1$ & 770 & 70 & 490 & 1,100 & 1,400 \\
\hline 45-Methylene_Phenanthrene & $<1$ & 1,310 & 300 & 1,900 & 3,200 & 4,100 \\
\hline 1-Methyl_Phenanthrene & $<1$ & 840 & 180 & 850 & 2,200 & 2,600 \\
\hline Fluoranthene & 2 & 5,400 & 2,600 & 8,300 & 8,400 & 11,000 \\
\hline Pyrene & 3 & 5,700 & 3,000 & 8,000 & 9,100 & 12,500 \\
\hline Retene & $<1$ & 29 & 27 & 30 & 530 & 860 \\
\hline Chrysene & 1 & 5,400 & 2,200 & 8,000 & 8,300 & 8,200 \\
\hline Benzo[b]naphtho[21-d]thiophene & $<1$ & 1,120 & 390 & 1,800 & 2,000 & 2,700 \\
\hline Benz[a]anthracene & $<1$ & 5,900 & 2,100 & 7,900 & 8,500 & 10,600 \\
\hline Benzo[b]fluoranthene & $<1$ & 7,500 & 3,300 & 12,100 & 13,800 & 16,900 \\
\hline Benzo[k]fluoranthene & $<1$ & 3,200 & 1,300 & 4,200 & 4,100 & 7,600 \\
\hline Benzo[e]pyrene & 1 & 4,600 & 2,000 & 7,100 & 7,800 & 8,600 \\
\hline Benzo[a]pyrene & $<1$ & 8,500 & 4,000 & 12,200 & 15,400 & 19,400 \\
\hline Perylene & $<1$ & 2,020 & 860 & 3,400 & 2,800 & 3,200 \\
\hline Indeno[123-cd]pyrene & $<1$ & 4,800 & 1,900 & 8,100 & 9,000 & 11,200 \\
\hline Dibenz[ah]anthracene & $<1$ & 1,240 & 480 & 2,000 & 1,700 & 2,300 \\
\hline Benzo[ghi]perylene & $<1$ & 5,800 & 2,500 & 10,200 & 12,100 & 16,000 \\
\hline
\end{tabular}

${ }^{1}$ Determined by dual-column, high-resolution capillary gas chromatography with mass selective detector (GC-MSD).

${ }^{2}$ Equivalents (EQ) derived from a split and diluted sample mass. 
Table 14. Measured concentrations $(\mathrm{ng} / \mathrm{mL})$ of elements in filtered sediment pore water from the Charles River (August, 2005). Priority pollutants are presented in bold. Method detection limits (MDL) and method quantitation limits (MQL) are provided for elements determined by inductively coupled plasma mass spectroscopy ICP-MS quantitative scan. All other elements determined by ICP-MS semi-quantitative scan. (NA, not applicable, ng/mL, nanogram per milliliter; <, concentrations below the reporting limits)

\begin{tabular}{|c|c|c|c|c|c|}
\hline Elements & MDL1 & $M Q^{2}$ & Sample 1 & Sample 2 & Sample 3 \\
\hline $\mathrm{Li}$ & NA & NA & 2 & 0.9 & 2 \\
\hline $\mathrm{Be}$ & NA & NA & $<.1$ & $<.1$ & $<.1$ \\
\hline $\mathrm{Na}$ & NA & NA & 80 & 60 & 90 \\
\hline $\mathrm{Mg}$ & NA & NA & 10 & 30 & 20 \\
\hline $\mathrm{Al}$ & NA & NA & 20 & 100 & 100 \\
\hline $\mathrm{K}$ & NA & NA & 5 & 4 & 5 \\
\hline $\mathrm{Ca}$ & NA & NA & 60 & 70 & 40 \\
\hline $\mathrm{Ti}$ & NA & NA & 3 & 8 & 7 \\
\hline $\mathrm{V}$ & NA & NA & .6 & 4 & .9 \\
\hline $\mathrm{Cr}$ & NA & NA & 200 & 8 & 400 \\
\hline $\mathrm{Mn}$ & NA & NA & 7,000 & 700 & 1,000 \\
\hline $\mathrm{Fe}$ & NA & NA & 200 & 20 & 1,000 \\
\hline Co & NA & NA & 3 & .3 & .3 \\
\hline $\mathbf{N i}$ & .35 & 1.16 & 1.44 & 1.52 & 1.59 \\
\hline $\mathrm{Cu}$ & 1.90 & 6.27 & $<1.9$ & $<6.27$ & $<6.27$ \\
\hline $\mathbf{Z n}$ & 25.00 & 82.50 & $<25.00$ & $<25.00$ & $<25.00$ \\
\hline $\mathrm{Ga}$ & NA & NA & 1 & .3 & .3 \\
\hline As & NA & NA & 3 & 7 & 3 \\
\hline $\mathbf{S e}$ & NA & NA & 1 & $<1$ & 3 \\
\hline $\mathrm{Ge}$ & NA & NA & $<.1$ & .7 & .1 \\
\hline $\mathrm{Rb}$ & NA & NA & 5 & 2 & 5 \\
\hline $\mathrm{Sr}$ & NA & NA & 400 & 400 & 300 \\
\hline $\mathrm{Y}$ & NA & NA & $<.1$ & .1 & .1 \\
\hline $\mathrm{Zr}$ & NA & NA & .6 & .4 & .7 \\
\hline $\mathrm{Nb}$ & NA & NA & $<.1$ & $<.1$ & $<.1$ \\
\hline Mo & NA & NA & 3 & 3 & 1 \\
\hline $\mathrm{Ru}$ & NA & NA & .2 & $<.1$ & $<.1$ \\
\hline $\mathrm{Pd}$ & NA & NA & $<.1$ & $<.1$ & $<.1$ \\
\hline Ag & NA & NA & $<.1$ & .1 & .8 \\
\hline Cd & .08 & .26 & .2 & .7 & .2 \\
\hline In & NA & NA & $<.1$ & $<.1$ & $<.1$ \\
\hline $\mathrm{Sn}$ & NA & NA & .2 & 1 & .8 \\
\hline Sb & NA & NA & .2 & 7 & 1 \\
\hline $\mathrm{Te}$ & NA & NA & $<.1$ & $<.1$ & $<.1$ \\
\hline Cs & NA & NA & .2 & $<.1$ & .1 \\
\hline $\mathrm{Ba}$ & NA & NA & 200 & 100 & 50 \\
\hline $\mathrm{La}$ & NA & NA & $<.1$ & .1 & .1 \\
\hline $\mathrm{Ce}$ & NA & NA & $<.1$ & .2 & .2 \\
\hline $\operatorname{Pr}$ & NA & NA & $<.1$ & $<.1$ & $<.1$ \\
\hline $\mathrm{Nd}$ & NA & NA & $<.1$ & .1 & .1 \\
\hline $\mathrm{Sm}$ & NA & NA & $<.1$ & $<.1$ & $<.1$ \\
\hline $\mathrm{Eu}$ & NA & NA & $<.1$ & $<.1$ & $<.1$ \\
\hline $\mathrm{Gd}$ & NA & NA & $<.1$ & $<.1$ & $<.1$ \\
\hline $\mathrm{Tb}$ & NA & NA & $<.1$ & $<.1$ & $<.1$ \\
\hline Dy & NA & NA & $<.1$ & $<.1$ & $<.1$ \\
\hline
\end{tabular}


Table 14. Measured concentrations $(\mathrm{ng} / \mathrm{mL})$ of elements in filtered sediment pore water from the Charles River (August, 2005). Priority pollutants are presented in bold. Method detection limits (MDL) and method quantitation limits (MQL) are provided for elements determined by inductively coupled plasma mass spectroscopy ICP-MS quantitative scan. All other elements determined by ICP-MS semi-quantitative scan. (NA, not applicable, ng/mL, nanogram per milliliter; <, concentrations below the reporting limits) -Continued

\begin{tabular}{|c|c|c|c|c|c|}
\hline Elements & MDL1 & $M Q^{2}$ & Sample 1 & Sample 2 & Sample 3 \\
\hline $\mathrm{Er}$ & NA & NA & $<.1$ & $<.1$ & $<.1$ \\
\hline $\mathrm{Tm}$ & NA & NA & $<.1$ & $<.1$ & $<.1$ \\
\hline $\mathrm{Yb}$ & NA & NA & $<.1$ & $<.1$ & $<.1$ \\
\hline $\mathrm{Lu}$ & NA & NA & $<.1$ & $<.1$ & $<.1$ \\
\hline $\mathrm{Hf}$ & NA & NA & $<.1$ & $<.1$ & $<.1$ \\
\hline $\mathrm{Ta}$ & NA & NA & $<.1$ & .1 & $<.1$ \\
\hline W & NA & NA & .2 & 1 & .4 \\
\hline $\operatorname{Re}$ & NA & NA & $<.1$ & $<.1$ & $<.1$ \\
\hline Os & NA & NA & $<.1$ & $<.1$ & $<.1$ \\
\hline $\mathrm{Ir}$ & NA & NA & $<.1$ & $<.1$ & $<.1$ \\
\hline $\mathrm{Pt}$ & NA & NA & $<.1$ & $<.1$ & $<.1$ \\
\hline $\mathrm{Au}$ & NA & NA & $<.1$ & $<.1$ & $<.1$ \\
\hline TI & NA & NA & $<.1$ & $<.1$ & $<.1$ \\
\hline $\mathbf{P b}$ & .18 & .59 & .6 & 10 & 8 \\
\hline $\mathrm{Bi}$ & NA & NA & $<.1$ & $<.1$ & $<.1$ \\
\hline $\mathrm{U}$ & NA & NA & 2 & .6 & .2 \\
\hline
\end{tabular}

${ }^{1} \mathrm{MDL}$, computed as $3 \times\left(\mathrm{SD}_{\mathrm{b}}{ }^{2}+\mathrm{SD}_{\mathrm{st}}{ }^{2}\right)^{1 / 2}$ where $\mathrm{SD}_{\mathrm{b}}=$ standard deviation of a reagent blank diluted $10 \times(n=3)$ and $\mathrm{SD}_{\mathrm{st}}=$ standard deviation of a low level standard diluted $100 \times(n=3)$.

${ }^{2} \mathrm{MQL}$, computed as $3.3 \times$ the MDL. 
Table 15. Measured concentrations ( $\mu \mathrm{g} / \mathrm{g}$ dry weight) of total recoverable elements in Charles River sediments collected August, 2005. Priority pollutants are presented in bold. Method detection limits (MDL) and method quantitation limits (MQL) are provided for elements determined by quantitative methods. (NA, not applicable; $\mu \mathrm{g} / \mathrm{g}$, microgram per gram; <, concentrations below the reporting limits)

\begin{tabular}{|c|c|c|c|c|c|}
\hline Elements 1 & $M^{2}{ }^{2}$ & $M Q L^{3}$ & Sample 1 & Sample 2 & Sample 3 \\
\hline $\mathrm{Li}$ & NA & NA & 10 & 20 & 20 \\
\hline $\mathbf{B e}$ & NA & NA & .60 & 1 & .80 \\
\hline $\mathrm{Na}$ & NA & NA & 300 & 500 & 700 \\
\hline $\mathrm{Mg}$ & NA & NA & 4,000 & 6,000 & 6,000 \\
\hline $\mathrm{Al}$ & NA & NA & 9,000 & 15,000 & 16,000 \\
\hline $\mathrm{K}$ & NA & NA & 1,000 & 3,000 & 3,000 \\
\hline $\mathrm{Ca}$ & NA & NA & 4,000 & 7,000 & 7,000 \\
\hline $\mathrm{Ti}$ & NA & NA & 400 & 400 & 600 \\
\hline $\mathrm{V}$ & NA & NA & 30 & 70 & 80 \\
\hline $\mathrm{Cr}$ & NA & NA & 30 & 100 & 100 \\
\hline $\mathrm{Mn}$ & NA & NA & 400 & 300 & 400 \\
\hline $\mathrm{Fe}$ & NA & NA & 12,000 & 15,000 & 17,000 \\
\hline $\mathrm{Co}$ & NA & NA & 6 & 10 & 10 \\
\hline $\mathbf{N i}$ & NA & NA & 10 & 40 & 50 \\
\hline $\mathbf{C u}$ & NA & NA & 30 & 200 & 300 \\
\hline $\mathbf{Z n}$ & NA & NA & 100 & 500 & 500 \\
\hline $\mathrm{Ga}$ & NA & NA & 7 & 10 & 10 \\
\hline As & .034 & .11 & 3.29 & 9.29 & 11.8 \\
\hline Se & .036 & .12 & .13 & .97 & .93 \\
\hline $\mathrm{Ge}$ & NA & NA & .20 & .50 & .40 \\
\hline $\mathrm{Rb}$ & NA & NA & 7 & 20 & 20 \\
\hline $\mathrm{Sr}$ & NA & NA & 30 & 70 & 70 \\
\hline $\mathrm{Y}$ & NA & NA & 8 & 10 & 10 \\
\hline $\mathrm{Zr}$ & NA & NA & 4 & 10 & 10 \\
\hline $\mathrm{Nb}$ & NA & NA & $<.04$ & $<.04$ & $<.04$ \\
\hline Mo & NA & NA & .70 & 1 & 2 \\
\hline $\mathrm{Ru}$ & NA & NA & $<.04$ & $<.04$ & $<.04$ \\
\hline $\mathrm{Pd}$ & NA & NA & .10 & $<.04$ & $<.04$ \\
\hline Ag & NA & NA & .09 & 5 & 20 \\
\hline Cd & NA & NA & .30 & 20 & 10 \\
\hline In & NA & NA & $<.04$ & .70 & .40 \\
\hline $\mathrm{Sn}$ & NA & NA & 5 & 30 & 20 \\
\hline $\mathrm{Sb}$ & NA & NA & .20 & .06 & $<.04$ \\
\hline $\mathrm{Te}$ & NA & NA & $<.04$ & .30 & $<.04$ \\
\hline Cs & NA & NA & .50 & 1 & 1 \\
\hline $\mathrm{Ba}$ & NA & NA & 50 & 200 & 200 \\
\hline $\mathrm{La}$ & NA & NA & 7 & 20 & 20 \\
\hline $\mathrm{Ce}$ & NA & NA & 20 & 30 & 40 \\
\hline $\operatorname{Pr}$ & NA & NA & 2 & 5 & 6 \\
\hline $\mathrm{Nd}$ & NA & NA & 8 & 20 & 20 \\
\hline $\mathrm{Sm}$ & NA & NA & 2 & 3 & 4 \\
\hline $\mathrm{Eu}$ & NA & NA & .40 & .80 & .80 \\
\hline
\end{tabular}


Table 15. Measured concentrations ( $\mu \mathrm{g} / \mathrm{g}$ dry weight) of total recoverable elements in Charles River sediments collected August, 2005. Priority pollutants are presented in bold. Method detection limits (MDL) and method quantitation limits (MQL) are provided for elements determined by quantitative methods. (NA, not applicable; $\mu \mathrm{g} / \mathrm{g}$, microgram per gram; <, concentrations below the reporting limits)—Continued

\begin{tabular}{|c|c|c|c|c|c|}
\hline Elements 1 & $\mathrm{MDL}^{2}$ & $M Q L^{3}$ & Sample 1 & Sample 2 & Sample 3 \\
\hline $\mathrm{Gd}$ & NA & NA & 2 & 4 & 4 \\
\hline $\mathbf{T b}$ & NA & NA & .30 & .50 & .50 \\
\hline Dy & NA & NA & 2 & 3 & 3 \\
\hline Ho & NA & NA & .30 & .50 & .50 \\
\hline Er & NA & NA & .80 & 1 & 1 \\
\hline $\mathrm{Tm}$ & NA & NA & .20 & .20 & .20 \\
\hline $\mathrm{Yb}$ & NA & NA & .70 & 1 & 1 \\
\hline $\mathrm{Lu}$ & NA & NA & .09 & .20 & .20 \\
\hline $\mathrm{Hf}$ & NA & NA & .10 & .30 & .30 \\
\hline $\mathrm{Ta}$ & NA & NA & $<.04$ & $<.04$ & $<.04$ \\
\hline W & NA & NA & $<.04$ & .60 & $<.04$ \\
\hline $\operatorname{Re}$ & NA & NA & $<.04$ & $<.04$ & $<.04$ \\
\hline Os & NA & NA & $<.04$ & $<.04$ & $<.04$ \\
\hline $\mathrm{Ir}$ & NA & NA & $<.04$ & $<.04$ & $<.04$ \\
\hline $\mathrm{Pt}$ & NA & NA & $<.04$ & $<.04$ & $<.04$ \\
\hline $\mathrm{Au}$ & NA & NA & $<.04$ & .06 & .06 \\
\hline Tl & NA & NA & .10 & .30 & .30 \\
\hline $\mathbf{P b}$ & NA & NA & 60 & 600 & 500 \\
\hline $\mathrm{Hg}$ & .007 & .022 & .042 & .94 & .94 \\
\hline $\mathrm{Bi}$ & NA & NA & .10 & .80 & .80 \\
\hline $\mathrm{U}$ & NA & NA & .80 & 2 & 2 \\
\hline
\end{tabular}

${ }^{1}$ As and Se determined by flow injection hydride generation atomic absorption spectroscopy. Hg determined by combustion-gold amalgamation atomic absorption spectroscopy. All other elements determined by ICP-MS semiquantitative scan.

${ }^{2} \mathrm{MDL}$, computed as $3 \times\left(\mathrm{SD}_{\mathrm{b}}{ }^{2}+\mathrm{SD}_{\mathrm{s}}{ }^{2}\right)^{1 / 2}$ where $\mathrm{SD}_{\mathrm{b}}=$ standard deviation of a blank and $\mathrm{SD}_{\mathrm{s}}=$ standard deviation of a low level sample or spiked sample $(n=3)$.

${ }^{3} \mathrm{MQL}(\mathrm{ng} / \mathrm{mL})$, computed as $3.3 \times$ the MDL. 
Table 16. Concentration (ng/g wet weight) of total polychlorinated biphenyls (PCBs) and organochlorine pesticides (OCPs) and percent lipids in composite samples of whole fish collected from the Charles River (August, 2005). (n, number of fish in composite sample; NA, not applicable; ng/g, nanogram per gram; <, concentrations below the reporting limits)

\begin{tabular}{|c|c|c|c|c|c|c|}
\hline Analytes $^{1}$ & $\begin{array}{l}\text { Method } \\
\text { detection } \\
\text { limit }^{2}\end{array}$ & $\begin{array}{c}\text { Method } \\
\text { quantitation } \text { limit }^{3}\end{array}$ & $\begin{array}{c}\text { Female } \\
\text { Common } \\
\text { carp } \\
(n=10) \\
\end{array}$ & $\begin{array}{c}\text { Male } \\
\text { common } \\
\text { carp } \\
(n=10) \\
\end{array}$ & $\begin{array}{c}\text { Female } \\
\text { largemouth } \\
\text { bass } \\
(n=8) \\
\end{array}$ & $\begin{array}{c}\text { Male } \\
\text { largemouth } \\
\text { bass } \\
(n=12) \\
\end{array}$ \\
\hline Percent lipid & NA & NA & 8.14 & 9.11 & 2.79 & 1.68 \\
\hline Pentachloro-benzene & .19 & .31 & 1.31 & 1.51 & .57 & .38 \\
\hline Hexachloro-benzene & .17 & .23 & 3.47 & 4.99 & 1.16 & .84 \\
\hline Pentachloro-anisole & .16 & .25 & 4.56 & 7.27 & 1.14 & .96 \\
\hline$\alpha-\mathrm{BHC}$ & .12 & .21 & 4.6 & .33 & .14 & $<.12$ \\
\hline$\beta$-BHC & .17 & .33 & .94 & $<.17$ & $<.17$ & $<.17$ \\
\hline Lindane & .11 & .15 & $<.11$ & .64 & $<.11$ & $<.11$ \\
\hline$\delta$-BHC & .12 & .23 & $<.12$ & $<.12$ & $<.12$ & $<.12$ \\
\hline Heptachlor & .12 & .15 & .20 & .22 & $<.12$ & $<.12$ \\
\hline Heptachlor epoxide & .14 & .20 & 4.87 & 6.04 & 3.09 & 1.97 \\
\hline Aldrin & .41 & 1.00 & $<.41$ & $<.41$ & $<.41$ & $<.41$ \\
\hline Dacthal & .18 & .32 & $<.18$ & $<.18$ & $<.18$ & $<.18$ \\
\hline Dieldrin & .17 & .38 & 14.03 & 16.38 & 9.01 & 6.03 \\
\hline Endrin & .29 & .71 & $<.29$ & $<.29$ & .82 & $<.29$ \\
\hline Oxychlordane & .14 & .18 & 7.72 & 9.52 & 10.90 & 9.75 \\
\hline cis-Chlordane & .36 & .99 & 75.67 & 88.46 & 29.44 & 19.50 \\
\hline trans-Chlordane & .30 & .83 & 45.42 & 50.12 & 11.57 & 7.98 \\
\hline cis-Nonachlor & .17 & .49 & 25.80 & 30.68 & 22.33 & 23.73 \\
\hline trans-Nonachlor & .37 & .96 & 57.18 & 71.45 & 51.57 & 53.76 \\
\hline$o, p^{\prime}-\mathrm{DDE}$ & .87 & 1.60 & 3.52 & 5.36 & 2.37 & 1.55 \\
\hline$o, p^{\prime}-\mathrm{DDD}$ & .25 & .71 & 25.02 & 26.57 & 11.49 & 6.49 \\
\hline$o, p^{\prime}-\mathrm{DDT}$ & .13 & .36 & 7.16 & 6.98 & 4.60 & 3.25 \\
\hline$p, p$-DDE & 6.30 & 15.00 & 230.00 & 310.00 & 180.00 & 230.00 \\
\hline$p, p$-DDD & 1.10 & 3.00 & 160.00 & 200.00 & 92.87 & 72.95 \\
\hline$p, p^{\prime}$-DDT & .12 & .37 & 5.17 & 6.97 & 15.28 & 16.92 \\
\hline Endosulfan I & .22 & .66 & $<.22$ & $<.22$ & $<.22$ & $<.22$ \\
\hline Endosulfan II & .45 & 1.30 & .62 & $<.45$ & $<.45$ & $<.45$ \\
\hline Endosulfate & .28 & .83 & .35 & .34 & $<.28$ & $<.28$ \\
\hline Methoxychlor & .56 & 1.50 & $<.56$ & $<.56$ & $<.56$ & $<.56$ \\
\hline Mirex & .15 & .17 & 1.29 & 1.98 & 1.24 & 1.42 \\
\hline Toxaphene & 19.00 & 52.00 & 54.56 & 99.94 & 40.01 & 26.18 \\
\hline Total PCBs & 28.00 & 59.00 & $2,166.67$ & $2,500.00$ & $1,800.00$ & $2,100.00$ \\
\hline
\end{tabular}

${ }^{1}$ Total PCBs and OCPs determined by dual-column, high-resolution, capillary gas chromatography with electroncapture detector.

${ }^{2}$ Method detection limit (MDL) is defined as the mean of procedural field blanks plus three standard deviations of coincident peaks in field blanks (Keith, 1991).

${ }^{3}$ Method quantitation limit (MQL) is defined as the mean of procedural field blanks plus ten standard deviations of coincident peaks in field blanks (Keith, 1991). 
Table 17. Concentrations of inorganic contaminants ( $\mu \mathrm{g} / \mathrm{g}$ dry weight) in composite samples of whole fish collected from the Charles River (August, 2005). $n$, number of fish in composite; $\mu \mathrm{g} / \mathrm{g}$, microgram per gram; <, concentrations below the detection limit)

\begin{tabular}{|c|c|c|c|c|c|c|}
\hline Elements $^{1}$ & $\begin{array}{c}\text { Female } \\
\text { common } \\
\text { carp } \\
(n=10)\end{array}$ & $\begin{array}{c}\text { Male } \\
\text { common } \\
\text { carp } \\
(n=10)\end{array}$ & $\begin{array}{c}\text { Female } \\
\text { largemouth } \\
\text { bass } \\
(n=8)\end{array}$ & $\begin{array}{c}\text { Male largemouth } \\
\text { Bass } \\
(n=12)\end{array}$ & $\begin{array}{c}\text { Female } \\
\text { white sucker } \\
(n=29)\end{array}$ & $\begin{array}{c}\text { Male } \\
\text { white sucker } \\
(n=11)\end{array}$ \\
\hline $\mathrm{Li}$ & $<0.04$ & $<0.04$ & $<0.04$ & $<0.04$ & $<0.04$ & 0.10 \\
\hline $\mathrm{Be}$ & $<.04$ & $<.04$ & $<.04$ & $<.04$ & $<.04$ & $<.04$ \\
\hline $\mathrm{Na}$ & 3,000 & 3,000 & 5,000 & 5,000 & 4,000 & 4,000 \\
\hline $\mathrm{Mg}$ & 1,000 & 1,000 & 2,000 & 2,000 & 1,000 & 2,000 \\
\hline $\mathrm{Al}$ & 30 & 10 & 10 & 30 & 50 & 50 \\
\hline $\mathrm{K}$ & 9,000 & 9,000 & 11,000 & 12,000 & 10,000 & 10,000 \\
\hline $\mathrm{Ca}$ & 22,000 & 15,000 & 43,000 & 38,000 & 28,000 & 48,000 \\
\hline $\mathrm{Ti}$ & 20 & 20 & 40 & 40 & 30 & 40 \\
\hline $\mathrm{V}$ & .20 & .20 & .08 & .10 & .80 & .40 \\
\hline $\mathrm{Cr}$ & 1 & 1 & 2 & 5 & 2 & 3 \\
\hline $\mathrm{Mn}$ & 10 & 10 & 8 & 20 & 30 & 40 \\
\hline $\mathrm{Fe}$ & 90 & 80 & 50 & 70 & 300 & 100 \\
\hline Co & .10 & .10 & .06 & .10 & .10 & .10 \\
\hline $\mathrm{Ni}$ & .40 & $<.40$ & 1 & 2 & .90 & 2 \\
\hline $\mathrm{Cu}$ & 5 & 4 & 3 & 2 & 2 & 2 \\
\hline $\mathrm{Zn}$ & 200 & 200 & 50 & 60 & 70 & 90 \\
\hline $\mathrm{Ga}$ & .20 & .20 & .20 & .20 & .20 & .30 \\
\hline $\mathrm{As}^{2}$ & .41 & .42 & .40 & .12 & .29 & .21 \\
\hline $\mathrm{Se}^{2}$ & 1.64 & 1.48 & 1.74 & 1.42 & 1.34 & 1.44 \\
\hline $\mathrm{Hg}^{2}$ & .20 & .26 & 1.18 & .93 & .46 & .45 \\
\hline $\mathrm{Ge}$ & $<.04$ & $<.04$ & $<.04$ & $<.04$ & $<.04$ & $<.04$ \\
\hline $\mathrm{Rb}$ & 6 & 6 & 10 & 10 & 7 & 7 \\
\hline $\mathrm{Sr}$ & 60 & 40 & 80 & 70 & 50 & 70 \\
\hline $\mathrm{Y}$ & $<.04$ & $<.04$ & $<.04$ & $<.04$ & .05 & .06 \\
\hline $\mathrm{Zr}$ & .07 & $<.04$ & .20 & $<.04$ & .04 & $<.04$ \\
\hline $\mathrm{Nb}$ & $<.04$ & $<.04$ & $<.04$ & $<.04$ & $<.04$ & $<.04$ \\
\hline Mo & .06 & .1 & .07 & .08 & .07 & .1 \\
\hline $\mathrm{Ru}$ & $<.04$ & $<.04$ & $<.04$ & $<.04$ & $<.04$ & $<.04$ \\
\hline $\mathrm{Pd}$ & $<.04$ & $<.04$ & $<.04$ & $<.04$ & $<.04$ & $<.04$ \\
\hline $\mathrm{Ag}$ & $<.04$ & $<.04$ & $<.04$ & $<.04$ & $<.04$ & $<.04$ \\
\hline $\mathrm{Cd}$ & .1 & .2 & $<.04$ & .05 & .1 & .07 \\
\hline In & $<.04$ & $<.04$ & $<.04$ & $<.04$ & $<.04$ & $<.04$ \\
\hline Sn & 5 & 10 & 1 & .10 & .20 & .20 \\
\hline $\mathrm{Sb}$ & $<.04$ & $<.04$ & $<.04$ & $<.04$ & $<.04$ & $<.04$ \\
\hline $\mathrm{Te}$ & $<.04$ & $<.04$ & $<.04$ & $<.04$ & $<.04$ & $<.04$ \\
\hline Cs & $<.04$ & $<.04$ & .10 & .10 & .07 & .06 \\
\hline $\mathrm{Ba}$ & 5 & 4 & 3 & 4 & 4 & 5 \\
\hline $\mathrm{La}$ & $<.04$ & $<.04$ & $<.04$ & $<.04$ & .06 & .05 \\
\hline $\mathrm{Ce}$ & $<.04$ & $<.04$ & $<.04$ & $<.04$ & .10 & .09 \\
\hline $\operatorname{Pr}$ & $<.04$ & $<.04$ & $<.04$ & $<.04$ & $<.04$ & $<.04$ \\
\hline $\mathrm{Nd}$ & $<.04$ & $<.04$ & $<.04$ & $<.04$ & .05 & .04 \\
\hline $\mathrm{Sm}$ & $<.04$ & $<.04$ & $<.04$ & $<.04$ & $<.04$ & $<.04$ \\
\hline $\mathrm{Eu}$ & $<.04$ & $<.04$ & $<.04$ & $<.04$ & $<.04$ & $<.04$ \\
\hline $\mathrm{Gd}$ & $<.04$ & $<.04$ & $<.04$ & $<.04$ & $<.04$ & $<.04$ \\
\hline $\mathrm{Tb}$ & $<.04$ & $<.04$ & $<.04$ & $<.04$ & $<.04$ & $<.04$ \\
\hline Dy & $<.04$ & $<.04$ & $<.04$ & $<.04$ & $<.04$ & $<.04$ \\
\hline
\end{tabular}


Table 17. Concentrations of inorganic contaminants ( $\mu \mathrm{g} / \mathrm{g}$ dry weight) in composite samples of whole fish collected from the Charles River (August, 2005). $n$, number of fish in composite; $\mu \mathrm{g} / \mathrm{g}$, microgram per gram; <, concentrations below the detection limit)-Continued

\begin{tabular}{ccccccc}
\hline Elements & $\begin{array}{c}\text { Female } \\
\text { common } \\
\text { carp } \\
(\boldsymbol{n}=\mathbf{1 0})\end{array}$ & $\begin{array}{c}\text { Male } \\
\text { common } \\
\text { carp } \\
(\boldsymbol{n}=\mathbf{1 0})\end{array}$ & $\begin{array}{c}\text { Female } \\
\text { largemouth } \\
\text { bass } \\
(\boldsymbol{n}=\mathbf{8})\end{array}$ & $\begin{array}{c}\text { Male largemouth } \\
\text { Bass } \\
(\boldsymbol{n}=\mathbf{1 2})\end{array}$ & $\begin{array}{c}\text { Female } \\
\text { white sucker } \\
(\boldsymbol{n}=\mathbf{2 9})\end{array}$ & $\begin{array}{c}\text { Male } \\
\text { white sucker } \\
(\boldsymbol{n}=\mathbf{1 1})\end{array}$ \\
\hline $\mathrm{Ho}$ & $<.04$ & $<.04$ & $<.04$ & $<.04$ & $<.04$ & $<.04$ \\
$\mathrm{Er}$ & $<.04$ & $<.04$ & $<.04$ & $<.04$ & $<.04$ & $<.04$ \\
$\mathrm{Tm}$ & $<.04$ & $<.04$ & $<.04$ & $<.04$ & $<.04$ & $<.04$ \\
$\mathrm{Yb}$ & $<.04$ & $<.04$ & $<.04$ & $<.04$ & $<.04$ & $<.04$ \\
$\mathrm{Lu}$ & $<.04$ & $<.04$ & $<.04$ & $<.04$ & $<.04$ & $<.04$ \\
$\mathrm{Hf}$ & $<.04$ & $<.04$ & $<.04$ & $<.04$ & $<.04$ & $<.04$ \\
$\mathrm{Ta}$ & $<.04$ & $<.04$ & $<.04$ & $<.04$ & $<.04$ & $<.04$ \\
$\mathrm{~W}$ & $<.04$ & $<.04$ & $<.04$ & $<.04$ & $<.04$ & $<.04$ \\
$\mathrm{Re}$ & $<.04$ & $<.04$ & $<.04$ & $<.04$ & $<.04$ & $<.04$ \\
$\mathrm{Os}$ & $<.04$ & $<.04$ & $<.04$ & $<.04$ & $<.04$ & $<.04$ \\
$\mathrm{Ir}$ & $<.04$ & $<.04$ & $<.04$ & $<.04$ & $<.04$ & $<.04$ \\
$\mathrm{Pt}$ & $<.04$ & $<.04$ & $<.04$ & $<.04$ & $<.04$ & $<.04$ \\
$\mathrm{Au}$ & $<.04$ & $<.04$ & $<.04$ & $<.04$ & $<.04$ & $<.04$ \\
$\mathrm{Tl}$ & $<.04$ & $<.04$ & $<.04$ & $<.04$ & $<.04$ & $<.04$ \\
$\mathrm{~Pb}$ & 2 & 2 & .30 & .60 & 20 & $<$ \\
$\mathrm{Bi}$ & $<.04$ & $<.04$ & $<.04$ & $<.04$ & $<.04$ & $<.04$ \\
$\mathrm{U}$ & $<.04$ & $<.04$ & $<.04$ & $<.04$ & $<.04$ & $<.04$ \\
\hline
\end{tabular}

${ }^{1}$ As and Se determined by flow injection hydride generation atomic absorption spectroscopy. Hg determined by combustion-gold amalgamation atomic absorption spectroscopy. All other elements determined by ICP-MS semiquantitative scan.

${ }^{2}$ Method detection limit (MDL) for As and Se is 0.029 and 0.005 for Hg. Method quantitation limit (MQL) is 0.1 for As and Se and 0.02 for $\mathrm{Hg}$. MDL computed as $3 \times\left(\mathrm{SD}_{\mathrm{b}}{ }^{2}+\mathrm{SD}_{\mathrm{s}}{ }^{2}\right)^{1 / 2}$ where $\mathrm{SD}_{\mathrm{b}}=$ standard deviation of a blank and $\mathrm{SD}_{\mathrm{s}}=$ standard deviation of a low-level sample or spiked sample $(n=3)$. MQL is computed as $3.3 \times$ the MDL. 
Table 18. Mercury concentrations ( $\mu \mathrm{g} / \mathrm{g}$ dry weight) as determined from muscle tissue (plug) collection from largemouth bass collected from the Charles River (August, 2005). (mm, millimeters; g, grams; Hg, mercury; $\mu \mathrm{g} / \mathrm{g}$, microgram per gram)

\begin{tabular}{lccccc}
\hline Fish ID & Gender & Length $(\mathrm{mm})$ & Weight $(\mathbf{g})$ & Age (years) & Hg muscle plug' \\
\hline LMB01 & $\mathrm{F}$ & 457 & 1,610 & 14 & 3.42 \\
LMB02 & $\mathrm{F}$ & 363 & 710 & 6 & 1.14 \\
LMB03 & $\mathrm{F}$ & 462 & 1,360 & 10 & 4.36 \\
LMB04 & $\mathrm{M}$ & 396 & 835 & 13 & 4.43 \\
LMB05 & $\mathrm{M}$ & 347 & 595 & 4 & 1.00 \\
LMB06 & $\mathrm{M}$ & 259 & 245 & 2 & .46 \\
LMB07 & $\mathrm{F}$ & 257 & 225 & 2 & .52 \\
LMB08 & $\mathrm{M}$ & 297 & 375 & 3 & .41 \\
LMB09 & $\mathrm{M}$ & 277 & 295 & 2 & .59 \\
LMB10 & $\mathrm{M}$ & 427 & 1,275 & 6 & .21 \\
LMB11 & $\mathrm{F}$ & 322 & 465 & 3 & .51 \\
LMB12 & $\mathrm{F}$ & 432 & 1,285 & 9 & .92 \\
LMB13 & $\mathrm{M}$ & 369 & 685 & 5 & .57 \\
LMB14 & $\mathrm{F}$ & 355 & 705 & 3 & 2.93 \\
LMB15 & $\mathrm{M}$ & 391 & 740 & 5 & 1.41 \\
LMB16 & $\mathrm{F}$ & 415 & 1,040 & 5 & .32 \\
LMB17 & $\mathrm{M}$ & 344 & 605 & 6 & .89 \\
LMB18 & $\mathrm{M}$ & 293 & 320 & 4 & .54 \\
LMB19 & $\mathrm{M}$ & 334 & 530 & 2 & .39 \\
LMB20 & $\mathrm{M}$ & 315 & 445 & 4 & \\
\hline
\end{tabular}

${ }^{1} \mathrm{Hg}$ determined by combustion-gold amalgamation atomic absorption spectroscopy. Method detection limit (MDL) for $\mathrm{Hg}$ is $0.005(\mu \mathrm{g} / \mathrm{g}$ dry weight). Method quantitation limit (MQL) is $0.02(\mu \mathrm{g} / \mathrm{g}$ dry weight). MDL computed as $3 \times$ $\left(\mathrm{SD}_{\mathrm{b}}{ }^{2}+\mathrm{SD}_{\mathrm{s}}{ }^{2}\right)^{1 / 2}$ where $\mathrm{SD}_{\mathrm{b}}=$ standard deviation of a blank and $\mathrm{SD}_{\mathrm{s}}=$ standard deviation of a low-level sample or spiked sample $(n=3)$. MQL is computed as $3.3 \times$ the MDL. 
Table 19. Concentration (ng/g wet weight) of total polychlorinated biphenyls (PCBs) and organochlorine pesticides (OCPs) and percent lipids in individual whole white suckers (WS) collected from the Charles River (August, 2005). (NA, not applicable; ng/g, nanogram per gram; <, concentrations below the detection limit)

\begin{tabular}{|c|c|c|c|c|c|c|c|c|c|c|c|c|}
\hline Contaminant ${ }^{1}$ & $\begin{array}{c}\text { Method } \\
\text { detection } \\
\text { limit }^{2}\end{array}$ & $\begin{array}{c}\text { Method } \\
\text { quantitation } \\
\text { limit }^{3}\end{array}$ & WS01 & WS02 & WS03 & WS04 & WS05 & WS06 & WS07 & WS08 & WS09 & WS10 \\
\hline Percent lipid & NA & NA & 9.57 & 5.27 & 12.10 & 7.00 & 10.85 & 2.95 & 4.94 & 3.65 & 6.25 & 8.50 \\
\hline $\begin{array}{l}\text { Pentachloro- } \\
\text { benzene }\end{array}$ & .19 & .31 & 1.55 & 1.05 & 1.81 & 1.44 & 1.76 & .68 & 1.09 & 1.06 & 1.18 & 1.39 \\
\hline $\begin{array}{l}\text { Hexachloro- } \\
\text { benzene }\end{array}$ & .17 & .23 & 4.06 & 2.24 & 6.34 & 3.31 & 3.65 & 1.58 & 1.99 & 1.79 & 1.70 & 2.58 \\
\hline $\begin{array}{l}\text { Pentachloro- } \\
\text { anisole }\end{array}$ & .16 & .25 & 9.61 & 5.14 & 10.04 & 8.77 & 7.96 & 4.35 & 4.93 & 3.74 & 3.71 & 6.67 \\
\hline$\alpha-\mathrm{BHC}$ & .12 & .21 & .49 & .31 & .24 & .47 & .54 & .27 & .56 & $<.12$ & .13 & .36 \\
\hline$\beta-\mathrm{BHC}$ & .17 & .33 & .88 & .31 & 1.50 & 1.46 & 1.04 & .35 & .51 & 1.50 & .19 & .66 \\
\hline Lindane & .11 & .15 & $<.11$ & $<.11$ & $<.11$ & $<.11$ & $<.11$ & $<.11$ & $<.11$ & $<.11$ & $<.11$ & $<.11$ \\
\hline$\delta$-BHC & .12 & .23 & $<.12$ & $<.12$ & $<.12$ & $<.12$ & $<.12$ & $<.12$ & $<.12$ & $<.12$ & $<.12$ & $<.12$ \\
\hline Heptachlor & .12 & .15 & .48 & .24 & .64 & .51 & .54 & .29 & .40 & .31 & .31 & .54 \\
\hline $\begin{array}{l}\text { Heptachlor- } \\
\text { epoxide }\end{array}$ & .14 & .20 & 6.20 & 4.09 & 7.40 & 6.49 & 9.04 & 3.64 & 5.12 & 3.88 & 5.56 & 6.23 \\
\hline Aldrin & .41 & 1.00 & $<.41$ & $<.41$ & $<.41$ & $<.41$ & .42 & $<.41$ & .47 & $<.41$ & $<.41$ & $<.41$ \\
\hline Dacthal & .18 & .32 & $<.18$ & $<.18$ & $<.18$ & $<.18$ & $<.18$ & $<.18$ & $<.18$ & $<.18$ & $<.18$ & $<.18$ \\
\hline Dieldrin & .17 & .38 & 170.00 & 14.35 & 210.00 & 27.18 & 43.03 & 11.58 & 20.92 & 11.85 & 20.51 & 20.44 \\
\hline Endrin & .29 & .71 & 1.02 & $<.29$ & .91 & .40 & $<.29$ & $<.29$ & $<.29$ & $<.29$ & $<.29$ & $<.29$ \\
\hline Oxychlordane & .14 & .18 & 9.30 & 12.65 & 17.68 & 17.11 & 16.50 & 6.34 & 10.04 & 9.20 & 11.54 & 14.59 \\
\hline cis-Chlordane & .36 & .99 & 68.98 & 73.46 & 96.90 & 96.78 & 102.49 & 36.51 & 69.08 & 43.50 & 65.77 & 72.70 \\
\hline trans-Chlordane & .30 & .83 & 36.32 & 28.50 & 40.67 & 51.73 & 59.14 & 19.98 & 39.32 & 27.06 & 35.56 & 46.66 \\
\hline cis-Nonachlor & .17 & .49 & 24.50 & 36.94 & 38.14 & 36.28 & 30.12 & 11.70 & 24.65 & 16.41 & 21.75 & 22.08 \\
\hline trans-Nonachlor & .37 & .96 & 52.68 & 90.07 & 84.29 & 77.87 & 73.57 & 24.96 & 66.95 & 41.32 & 55.48 & 54.30 \\
\hline$o, p^{\prime}-\mathrm{DDE}$ & .87 & 1.60 & 1.49 & 1.61 & 3.49 & 3.35 & 3.10 & $<.87$ & 1.69 & $<.87$ & $<.87$ & 1.48 \\
\hline$o, p$ 'DDD & .25 & .71 & 17.19 & 15.51 & 24.75 & 16.16 & 21.94 & 6.01 & 15.06 & 7.91 & 8.83 & 14.28 \\
\hline$o, p^{\prime}-\mathrm{DDT}$ & .13 & .36 & 11.77 & 9.94 & 17.46 & 10.67 & 12.31 & 4.12 & 10.11 & 5.65 & 8.17 & 9.67 \\
\hline$p, p$ '-DDE & 6.30 & 15.00 & 180.00 & 320.00 & 260.00 & 280.00 & 220.00 & 96.37 & 240.00 & 150.00 & 180.00 & 160.00 \\
\hline$p, p$-DDD & 1.10 & 3.00 & 120.00 & 180.00 & 200.00 & 130.00 & 160.00 & 50.46 & 130.00 & 66.45 & 75.43 & 89.78 \\
\hline$p, p$ '-DDT & .12 & .37 & 43.97 & 70.48 & 68.37 & 53.27 & 50.91 & 20.07 & 54.37 & 29.99 & 42.13 & 34.84 \\
\hline Endosulfan I & .22 & .66 & $<.22$ & $<.22$ & $<.22$ & $<.22$ & $<.22$ & $<.22$ & $<.22$ & $<.22$ & $<.22$ & $<.22$ \\
\hline Endosulfan II & .45 & 1.30 & .68 & 1.33 & 1.47 & 1.58 & .53 & .73 & .58 & $<.45$ & 1.01 & .61 \\
\hline Endosulfate & .28 & .83 & .53 & $<.28$ & .57 & .33 & .45 & $<.28$ & $<.28$ & $<.28$ & $<.28$ & $<.28$ \\
\hline
\end{tabular}


Table 19. Concentration (ng/g wet weight) of total polychlorinated biphenyls (PCBs) and organochlorine pesticides (OCPs) and percent lipids in individual whole white suckers (WS) collected from the Charles River (August, 2005). (NA, not applicable; ng/g, nanogram per gram; <, concentrations below the detection limit) -Continued

\begin{tabular}{|c|c|c|c|c|c|c|c|c|c|c|c|c|c|}
\hline Contaminant ${ }^{1}$ & $\begin{array}{c}\text { Method } \\
\text { detection } \\
\text { limit }^{2}\end{array}$ & $\begin{array}{c}\text { Method } \\
\text { quantitation } \\
\text { limit }^{3}\end{array}$ & WS01 & WS02 & WS03 & WS04 & & S05 & WS06 & WS07 & WS08 & WS09 & WS10 \\
\hline Methoxychlor & .56 & 1.50 & $<.56$ & $<.56$ & $<.56$ & $<.56$ & & .56 & $<.56$ & $<.56$ & $<.56$ & $<.56$ & $<.56$ \\
\hline Mirex & .15 & .17 & .87 & 1.38 & 1.52 & 1.29 & & .92 & .55 & 1.27 & .75 & .90 & .68 \\
\hline Toxaphene & 19.00 & 52.00 & 78.13 & 47.45 & 65.64 & 74.58 & & 0.88 & 18.33 & 36.20 & $<19$ & 51.30 & 25.92 \\
\hline Total PCBs & 28.00 & 59.00 & $1,700.00$ & $2,600.00$ & $2,900.00$ & $2,500.00$ & 2,10 & 0.00 & $1,023.33$ & $1,700.00$ & 960.00 & $1,300.00$ & $1,100.00$ \\
\hline Contaminant ${ }^{1}$ & $\begin{array}{c}\text { Method } \\
\text { detection } \\
\text { limit }^{2} \\
\end{array}$ & $\begin{array}{c}\text { Method } \\
\text { quantitation } \\
\text { limit }^{3} \\
\end{array}$ & WS11 & WS12 & WS13 & WS14 & WS15 & WS16 & WS17 & WS18 & WS19 & WS20 & WS21 \\
\hline Percent lipid & NA & NA & 7.16 & 7.73 & 3.93 & 12.17 & 10.85 & 2.78 & 9.43 & 8.10 & 8.56 & 11.15 & 9.87 \\
\hline $\begin{array}{l}\text { Pentachloro- } \\
\text { benzene }\end{array}$ & .19 & .31 & 1.73 & 1.36 & .76 & 2.03 & 1.85 & .71 & 2.08 & 1.74 & 1.90 & 1.82 & 1.93 \\
\hline Hexachloro-benzene & .17 & .23 & 2.21 & 3.43 & 1.74 & 7.07 & 3.10 & 1.08 & 4.00 & 8.18 & 6.65 & 5.06 & 5.71 \\
\hline Pentachloro-anisole & .16 & .25 & 6.04 & 6.86 & 3.34 & 7.34 & 8.79 & 3.56 & 12.52 & 7.56 & 4.56 & 7.73 & 8.12 \\
\hline$\alpha-\mathrm{BHC}$ & .12 & .21 & .30 & .32 & .23 & .71 & .69 & .39 & .96 & .83 & .78 & .50 & .87 \\
\hline$\beta-\mathrm{BHC}$ & .17 & .33 & $<.17$ & $<.17$ & $<.17$ & $<.17$ & $<.17$ & $<.17$ & $<.17$ & $<.17$ & $<.17$ & $<.17$ & 1.80 \\
\hline Lindane & .11 & .15 & $<.11$ & $<.11$ & $<.11$ & $<.11$ & $<.11$ & $<.11$ & $<.11$ & $<.11$ & $<.11$ & $<.11$ & $<.11$ \\
\hline$\delta$-BHC & .12 & .23 & $<.12$ & $<.12$ & $<.12$ & $<.12$ & $<.12$ & $<.02$ & $<.12$ & $<.12$ & $<.12$ & $<.12$ & $<.12$ \\
\hline Heptachlor & .12 & .15 & .49 & .42 & .32 & .55 & .56 & .31 & .82 & .46 & .56 & .33 & .72 \\
\hline Heptachlor epoxide & .14 & .20 & 5.68 & 5.11 & 3.57 & 9.20 & 8.33 & 3.28 & 9.24 & 7.08 & 6.97 & 8.71 & 6.99 \\
\hline Aldrin & .41 & 1.00 & $<.41$ & $<.41$ & $<.41$ & $<.41$ & .45 & $<.41$ & $<.41$ & $<.41$ & $<.41$ & $<.41$ & .56 \\
\hline Dacthal & .18 & .32 & $<.18$ & $<.18$ & $<.18$ & $<.18$ & $<.18$ & $<.18$ & $<.18$ & $<.18$ & $<.18$ & $<.18$ & $<.18$ \\
\hline Dieldrin & .17 & .38 & 19.75 & 62.32 & 15.17 & 40.32 & 26.47 & 10.43 & 32.42 & 34.32 & 32.16 & 100.00 & 53.35 \\
\hline Endrin & .29 & .71 & .80 & $<.29$ & $<.29$ & $<.29$ & .77 & $<.29$ & $<.29$ & $<.29$ & $<.29$ & $<.29$ & .30 \\
\hline Oxychlordane & .14 & .18 & 13.67 & 7.04 & 7.44 & 21.49 & 21.59 & 8.49 & 45.44 & 16.22 & 14.05 & 19.93 & 12.68 \\
\hline cis-Chlordane & .36 & .99 & 70.79 & 43.76 & 45.29 & 93.08 & 105.70 & 46.00 & 141.49 & 72.49 & 80.14 & 89.22 & 79.59 \\
\hline trans-Chlordane & .30 & .83 & 40.89 & 27.45 & 26.11 & 39.83 & 64.84 & 22.44 & 51.17 & 31.97 & 41.18 & 32.11 & 45.75 \\
\hline cis-NoNDchlor & .17 & .49 & 23.08 & 12.44 & 15.64 & 30.76 & 37.39 & 20.49 & 59.11 & 22.74 & 24.48 & 36.31 & 27.25 \\
\hline trans-NoNDchlor & .37 & .96 & 55.32 & 31.46 & 38.05 & 72.82 & 89.58 & 51.55 & 160.00 & 54.23 & 62.95 & 73.80 & 56.12 \\
\hline$o, p^{\prime}-\mathrm{DDE}$ & .87 & 1.60 & 3.20 & 2.08 & .98 & 3.85 & 4.29 & ND & 4.01 & 4.49 & 3.21 & 3.21 & 5.75 \\
\hline$o, p$ '-DDD & .25 & .71 & 13.15 & 11.41 & 7.35 & 20.55 & 21.44 & 6.01 & 23.04 & 23.62 & 19.94 & 20.18 & 27.61 \\
\hline
\end{tabular}


Table 19. Concentration (ng/g wet weight) of total polychlorinated biphenyls (PCBs) and organochlorine pesticides (OCPs) and percent lipids in individual whole white suckers (WS) collected from the Charles River (August, 2005). (NA, not applicable; ng/g, nanogram per gram; <, concentrations below the detection limit)-Continued

\begin{tabular}{|c|c|c|c|c|c|c|c|c|c|c|c|c|c|}
\hline Contaminant $^{1}$ & $\begin{array}{l}\text { Method } \\
\text { detection } \\
\text { limit }^{2}\end{array}$ & $\begin{array}{c}\text { Method } \\
\text { quantitation } \\
\text { limit }^{3}\end{array}$ & WS11 & WS12 & WS13 & WS14 & WS15 & WS16 & WS17 & WS18 & WS19 & WS20 & WS21 \\
\hline$o, p^{\prime}$-DDT & .13 & .36 & 7.81 & 6.47 & 4.82 & 10.96 & 11.95 & 4.26 & 17.96 & 16.16 & 8.14 & 12.00 & 6.90 \\
\hline$p, p$ '-DDE & 6.30 & 15.00 & 180.00 & 99.39 & 120.00 & 250.00 & 280.002 & 230.00 & 450.00 & 170.00 & 210.00 & 300.00 & 170.00 \\
\hline$p, p$-DDD & 1.10 & 3.00 & 100.00 & 78.22 & 73.73 & 160.00 & 160.00 & 70.86 & 250.00 & 140.00 & 160.00 & 210.00 & 160.00 \\
\hline$p, p$-DDT & .12 & .37 & 45.99 & 21.84 & 25.11 & 49.09 & 55.76 & 44.83 & 120.00 & 44.68 & 40.35 & 62.69 & 29.82 \\
\hline Endosulfan I & .22 & .66 & $<.22$ & $<.22$ & $<.22$ & $<.22$ & $<.22$ & $<.22$ & $<.22$ & $<.22$ & $<.22$ & $<.22$ & $<.22$ \\
\hline Endosulfan II & .45 & 1.30 & $<.45$ & .46 & $<.45$ & .57 & .91 & ND & 1.10 & .99 & .67 & $<.45$ & .83 \\
\hline Endosulfate & .28 & .83 & $<.28$ & $<.28$ & $<.28$ & .35 & .31 & $<.28$ & .34 & .34 & .29 & .48 & .37 \\
\hline Methoxychlor & .56 & 1.50 & $<.56$ & $<.56$ & $<.56$ & $<.56$ & $<.56$ & $<.56$ & $<.56$ & $<.56$ & $<.56$ & $<.56$ & $<.56$ \\
\hline Mirex & .15 & .17 & .89 & .44 & .59 & 1.05 & 1.26 & 1.46 & 2.03 & .84 & .82 & 1.39 & .86 \\
\hline Toxaphene & 19.00 & 52.00 & 42.56 & 29.72 & $<19$ & 39.19 & 87.94 & 33.58 & 46.48 & 72.38 & 48.67 & 41.68 & 52.95 \\
\hline Total PCBs & 28.00 & 59.00 & $1,700.00$ & $1,100.00$ & $1,200.00$ & $2,300.00$ & $2,100.001$ &, 600.00 & $3,000.00$ & $1,800.00$ & $2,600.00$ & $2,500.00$ & $2,100.00$ \\
\hline Contaminant $^{1}$ & $\begin{array}{c}\text { Method } \\
\text { detection } \\
\text { limit2 } \\
\end{array}$ & $\begin{array}{c}\text { Method } \\
\text { quantitation } \\
\text { limit }^{3} \\
\end{array}$ & WS22 & WS23 & & WS24 & WS25 & WS26 & \multicolumn{3}{|r|}{ WS28 } & WS29 & WS30 \\
\hline Percent lipid & NA & NA & 5.08 & 9.50 & & 3.25 & 9.37 & 8.54 & \multicolumn{3}{|r|}{8.23} & 12.51 & 5.71 \\
\hline $\begin{array}{l}\text { Pentachloro- } \\
\text { benzene }\end{array}$ & .19 & .31 & 1.58 & 1.48 & & 1.51 & 1.53 & 1.33 & \multicolumn{3}{|r|}{1.34} & 1.94 & .76 \\
\hline $\begin{array}{l}\text { Hexachloro- } \\
\text { benzene }\end{array}$ & .17 & .23 & 1.80 & 3.85 & & 4.98 & 2.55 & 2.63 & \multicolumn{3}{|r|}{5.48} & 3.85 & 2.51 \\
\hline $\begin{array}{l}\text { Pentachloro- } \\
\text { anisole }\end{array}$ & .16 & .25 & 6.87 & 7.05 & & 5.66 & 8.85 & 7.30 & \multicolumn{3}{|r|}{8.12} & 10.85 & 4.81 \\
\hline$\alpha-\mathrm{BHC}$ & .12 & .21 & .49 & .24 & & .54 & .47 & .50 & \multicolumn{3}{|r|}{.49} & .92 & .44 \\
\hline$\beta-\mathrm{BHC}$ & .17 & .33 & .89 & 1.05 & & 1.12 & 1.76 & 1.86 & \multicolumn{3}{|r|}{2.12} & 1.81 & 2.44 \\
\hline Lindane & .11 & .15 & $<.11$ & $<.11$ & & .11 & $<.11$ & $<.11$ & \multicolumn{3}{|r|}{$<.11$} & $<.11$ & $<.11$ \\
\hline$\delta$-BHC & .12 & .23 & $<.12$ & $<.12$ & & .12 & $<.12$ & $<.12$ & \multirow{2}{*}{\multicolumn{3}{|c|}{$\begin{array}{r}<.12 \\
.57\end{array}$}} & $<.12$ & $<.12$ \\
\hline Heptachlor & .12 & .15 & .68 & .30 & & .31 & .29 & .36 & & & & 1.12 & .20 \\
\hline $\begin{array}{l}\text { Heptachlor } \\
\text { epoxide }\end{array}$ & .14 & .20 & 4.63 & 6.12 & & 5.51 & 7.92 & 5.82 & \multicolumn{3}{|r|}{5.38} & 8.56 & 3.27 \\
\hline Aldrin & .41 & 1.00 & $<.41$ & $<.41$ & & .41 & $<.41$ & $<.41$ & \multicolumn{3}{|r|}{.47} & $<.41$ & $<.41$ \\
\hline Dacthal & .18 & .32 & $<.18$ & $<.18$ & & .18 & $<.18$ & $<.18$ & \multicolumn{3}{|r|}{$<.18$} & $<.18$ & $<.18$ \\
\hline
\end{tabular}


Table 19. Concentration (ng/g wet weight) of total polychlorinated biphenyls (PCBs) and organochlorine pesticides (OCPs) and percent lipids in individual whole white suckers (WS) collected from the Charles River (August, 2005). (NA, not applicable; ng/g, nanogram per gram; <, concentrations below the detection limit)-Continued

\begin{tabular}{|c|c|c|c|c|c|c|c|c|c|c|c|}
\hline Contaminant ${ }^{1}$ & $\begin{array}{c}\text { Method } \\
\text { detection } \\
\text { limit2 }\end{array}$ & $\begin{array}{c}\text { Method } \\
\text { quantitation } \\
\text { limit }^{3}\end{array}$ & WS22 & WS23 & WS24 & WS25 & WS26 & WS27 & WS28 & WS29 & WS30 \\
\hline Dieldrin & .17 & .38 & 14.48 & 160.00 & 43.95 & 96.16 & 33.49 & 29.78 & 110.00 & 29.26 & 92.38 \\
\hline Endrin & .29 & .71 & $<.29$ & .70 & $<.29$ & .31 & ND & $<.29$ & .69 & .50 & .47 \\
\hline Oxychlordane & .14 & .18 & 17.61 & 14.63 & 12.48 & 12.34 & 9.64 & 11.09 & 11.55 & 30.00 & 7.33 \\
\hline cis-Chlordane & .36 & .99 & 75.18 & 73.52 & 66.51 & 61.84 & 53.18 & 51.60 & 54.60 & 128.94 & 39.74 \\
\hline trans-Chlordane & .30 & .83 & 31.20 & 25.55 & 35.49 & 23.42 & 27.64 & 30.23 & 35.05 & 72.78 & 18.09 \\
\hline cis-NoNDchlor & .17 & .49 & 38.94 & 30.42 & 23.51 & 22.78 & 14.96 & 16.15 & 16.22 & 51.86 & 16.31 \\
\hline $\begin{array}{l}\text { trans- } \\
\text { NoNDchlor }\end{array}$ & .37 & .96 & 110.00 & 58.49 & 52.23 & 46.41 & 35.57 & 39.30 & 37.29 & 130.00 & 30.77 \\
\hline$o, p^{\prime}-\mathrm{DDE}$ & .87 & 1.60 & 3.43 & 3.64 & 4.43 & 3.28 & 3.43 & 4.01 & 2.56 & 7.88 & 2.31 \\
\hline$o, p$-DDD & .25 & .71 & 14.64 & 18.30 & 16.78 & 12.70 & 14.97 & 11.69 & 14.73 & 22.10 & 10.91 \\
\hline$o, p$-DDT & .13 & .36 & 7.61 & 6.68 & 6.02 & 6.07 & 4.66 & 5.16 & 4.00 & 12.39 & 4.25 \\
\hline$p, p$-DDE & 6.30 & 15.00 & 490.00 & 250.00 & 160.00 & 160.00 & 92.80 & 140.00 & 130.00 & 480.00 & 150.00 \\
\hline$p, p$-DDD & 1.10 & 3.00 & 170.00 & 160.00 & 120.00 & 98.18 & 93.11 & 90.38 & 89.37 & 190.00 & 86.50 \\
\hline$p, p$-DDT & .12 & .37 & 92.22 & 49.04 & 33.14 & 37.80 & 17.56 & 24.77 & 19.70 & 98.72 & 31.55 \\
\hline Endosulfan I & .22 & .66 & $<.22$ & $<.22$ & $<.22$ & $<.22$ & $<.22$ & $<.22$ & $<.22$ & $<.22$ & $<.22$ \\
\hline Endosulfan II & .45 & 1.30 & .54 & .46 & .66 & $<.45$ & ND & .50 & .90 & 2.04 & $<.45$ \\
\hline Endosulfate & .28 & .83 & $<.28$ & .54 & $<.28$ & .52 & $<.28$ & $<.28$ & .31 & .37 & $<.28$ \\
\hline Methoxychlor & .56 & 1.50 & $<.56$ & $<.56$ & $<.56$ & $<.56$ & $<.56$ & $<.56$ & $<.56$ & $<.56$ & $<.56$ \\
\hline Mirex & .15 & .17 & 2.22 & 1.57 & .61 & .81 & .35 & .48 & .47 & 1.87 & .66 \\
\hline Toxaphene & 19.00 & 52.00 & 86.18 & 65.01 & 32.57 & 64.72 & 34.81 & 31.25 & 29.91 & 100.00 & 43.73 \\
\hline Total PCBs & 28.00 & 59.00 & $3,300.00$ & $2,500.00$ & $2,200.00$ & $1,700.00$ & $1,100.00$ & $1,300.00$ & $1,700.00$ & $3,600.00$ & $1,500.00$ \\
\hline
\end{tabular}

${ }^{1}$ Total PCBs and OCPs determined by dual-column, high-resolution, capillary gas chromatography with electron-capture detector.

${ }^{2}$ Method detection limit (MDL) is defined as the mean of procedural field blanks plus three standard deviations of coincident peaks in field blanks (Keith, 1991).

${ }^{3}$ Method quantitation limit (MQL) is defined as the mean of procedural field blanks plus ten standard deviations of coincident peaks in field blanks (Keith, 1991). 
Table 20. Bile concentrations $(\mu \mathrm{g} / \mathrm{mL})$ of polycyclic aromatic hydrocarbon $(\mathrm{PAH})$ metabolites from common carp, largemouth bass, and white suckers collected from the Charles River (August, 2005). Concentrations determined by reverse phase HPLC with fluorescence detection (Krahn and others, 1984). Method detection limits were 0.6 and $0.05(\mu \mathrm{g} / \mathrm{mL})$ for naphthalene and benzo[a]pyrene metabolites respectively. (ND, not determined; $\mu \mathrm{g} / \mathrm{mL}$, micrograms per milliliter)

\begin{tabular}{|c|c|c|c|c|c|}
\hline Species & Fish ID & $\begin{array}{l}\text { Naphthalene } \\
(\mu \mathrm{g} / \mathrm{mL})\end{array}$ & $\begin{array}{c}\text { Benzo[a]pyrene } \\
(\mu \mathrm{g} / \mathrm{mL})\end{array}$ & $\begin{array}{l}\text { Naphthalene }^{1} \\
(\mu \mathrm{g} / \mathrm{mL} \text { protein })\end{array}$ & $\begin{array}{c}\text { Benzo[a]pyrene } \\
\text { ( } \mu \mathrm{g} / \mathrm{mL} \text { protein) }\end{array}$ \\
\hline Common carp & $\mathrm{CC} 01$ & 150 & 1.6 & 93.8 & 1 \\
\hline Common carp & $\mathrm{CC} 02^{2}$ & 21 & 0.1 & 0.6 & 0 \\
\hline Common carp & $\mathrm{CC} 03$ & 160 & 1.5 & 106.1 & 1 \\
\hline Common carp & $\mathrm{CC} 04$ & 240 & 2.1 & 258.8 & 2.26 \\
\hline Common carp & $\mathrm{CC} 05$ & 130 & 1.2 & 51.7 & 0.48 \\
\hline Common carp & $\mathrm{CC} 06$ & 130 & 0.9 & 182 & 1.27 \\
\hline Common carp & $\mathrm{CC} 07$ & 120 & 1 & 223.8 & 1.83 \\
\hline Common carp & $\mathrm{CC} 08$ & 92 & 0.8 & 29.9 & 0.27 \\
\hline Common carp & $\mathrm{CC} 09$ & 170 & 1.5 & 167.1 & 1.47 \\
\hline Common carp & $\mathrm{CC} 10$ & 160 & 1.6 & 147.4 & 1.47 \\
\hline Common carp & $\mathrm{CC} 11$ & 91 & 1 & 71.9 & 0.79 \\
\hline Common carp & $\mathrm{CC} 12$ & 150 & 1.2 & 181.5 & 1.45 \\
\hline Common carp & $\mathrm{CC} 13$ & 160 & 1.6 & 217.2 & 2.17 \\
\hline Common carp & $\mathrm{CC} 14$ & 160 & 1.4 & 152.2 & 1.33 \\
\hline Common carp & $\mathrm{CC} 15$ & 240 & 1.5 & 68.5 & 0.43 \\
\hline Common carp & $\mathrm{CC} 16$ & 160 & 0.9 & 15.5 & 0.09 \\
\hline Common carp & $\mathrm{CC} 17$ & ND & ND & ND & ND \\
\hline Common carp & $\mathrm{CC} 18$ & 180 & 1.6 & 256 & 2.28 \\
\hline Common carp & CC19 & 140 & 1.8 & 80 & 1.03 \\
\hline Common carp & $\mathrm{CC} 20$ & 190 & 1.8 & 160 & 1.52 \\
\hline Largemouth bass & LMB01 & 890 & 17 & 98.6 & 1.88 \\
\hline Largemouth bass & LMB02 & 410 & 5.7 & 81.4 & 1.13 \\
\hline Largemouth bass & LMB03 & 510 & 12 & 58 & 1.36 \\
\hline Largemouth bass & LMB04 & 430 & 6.3 & 77 & 1.13 \\
\hline Largemouth bass & LMB05 & 360 & 5.8 & 90.8 & 1.46 \\
\hline Largemouth bass & LMB06 & 280 & 3.3 & 119.3 & 1.41 \\
\hline Largemouth bass & LMB07 & 260 & 3.2 & 47.2 & 0.58 \\
\hline Largemouth bass & LMB08 & ND & ND & ND & ND \\
\hline Largemouth bass & LMB09 & ND & ND & ND & ND \\
\hline
\end{tabular}


Table 20. Bile concentrations $(\mu \mathrm{g} / \mathrm{mL})$ of polycyclic aromatic hydrocarbon $(\mathrm{PAH})$ metabolites from common carp, largemouth bass, and white suckers collected from the Charles River (August, 2005). Concentrations determined by reverse phase HPLC with fluorescence detection (Krahn and others, 1984). Method detection limits were 0.6 and $0.05(\mu \mathrm{g} / \mathrm{mL})$ for naphthalene and benzo[a]pyrene metabolites respectively. (ND, not determined; $\mu \mathrm{g} / \mathrm{mL}$, micrograms per milliliter)—Continued

\begin{tabular}{|c|c|c|c|c|c|}
\hline Species & Fish ID & $\begin{array}{l}\text { Naphthalene } \\
(\mu \mathrm{g} / \mathrm{mL})\end{array}$ & $\begin{array}{l}\text { Benzo[a]pyrene } \\
(\mu \mathrm{g} / \mathrm{mL})\end{array}$ & $\begin{array}{c}\text { Naphthalene }{ }^{1} \\
\text { ( } \mu \mathrm{g} / \mathrm{mL} \text { protein) }\end{array}$ & $\begin{array}{l}\text { Benzo[a]pyrene }{ }^{1} \\
\text { ( } \mu \mathrm{g} / \mathrm{mL} \text { protein) }\end{array}$ \\
\hline Largemouth bass & LMB10 & 300 & 3.7 & 144.5 & 1.78 \\
\hline Largemouth bass & LMB11 & 100 & 1.2 & 101.7 & 1.22 \\
\hline Largemouth bass & LMB12 & 500 & 6.5 & 125.4 & 1.63 \\
\hline Largemouth bass & LMB13 & ND & ND & ND & ND \\
\hline Largemouth bass & LMB14 & 470 & 5.9 & 113.9 & 1.43 \\
\hline Largemouth bass & LMB15 & 400 & 5 & 123.1 & 1.54 \\
\hline Largemouth bass & LMB16 & 1,000 & 15 & 199.4 & 2.99 \\
\hline Largemouth bass & LMB17 & 290 & 3.9 & 88.9 & 1.2 \\
\hline Largemouth bass & LMB18 & 500 & 5.6 & 112.9 & 1.26 \\
\hline Largemouth bass & LMB19 & 540 & 7.3 & 80.6 & 1.09 \\
\hline Largemouth bass & LMB20 & 280 & 2.6 & 184.3 & 1.71 \\
\hline White sucker & WS01 & 1,200 & 15 & 172.5 & 2.16 \\
\hline White sucker & WS02 & 870 & 10 & 151.9 & 1.75 \\
\hline White sucker & WS03 & 600 & 7.3 & 114.3 & 1.39 \\
\hline White sucker & WS04 & 280 & 3.7 & 117.5 & 1.55 \\
\hline White sucker & WS05 & 430 & 5.3 & 119.2 & 1.47 \\
\hline White sucker & WS06 & 320 & 5 & 84.4 & 1.32 \\
\hline White sucker & WS07 & 380 & 5.6 & 113.9 & 1.68 \\
\hline White sucker & WS08 & 270 & 3.8 & 69.1 & 0.97 \\
\hline White sucker & WS09 & ND & ND & ND & ND \\
\hline White sucker & WS10 & ND & ND & ND & ND \\
\hline White sucker & WS11 & 340 & 3.2 & 169.5 & 1.6 \\
\hline White sucker & WS12 & 350 & 3.9 & 143.2 & 1.6 \\
\hline White sucker & WS13 & 420 & 5 & 44.2 & 0.53 \\
\hline White sucker & WS14 & 370 & 2.9 & 159.4 & 1.25 \\
\hline White sucker & WS15 & 490 & 4.4 & 138.8 & 1.25 \\
\hline White sucker & WS16 & 490 & 4.4 & 153.9 & 1.38 \\
\hline White sucker & WS17 & 490 & 5.7 & 130.2 & 1.51 \\
\hline White sucker & WS18 & 1,000 & 15 & 110 & 1.65 \\
\hline White sucker & WS19 & 650 & 5.5 & 174.5 & 1.48 \\
\hline
\end{tabular}


Table 20. Bile concentrations $(\mu \mathrm{g} / \mathrm{mL})$ of polycyclic aromatic hydrocarbon $(\mathrm{PAH})$ metabolites from common carp, largemouth bass, and white suckers collected from the Charles River (August, 2005). Concentrations determined by reverse phase HPLC with fluorescence detection (Krahn and others, 1984). Method detection limits were 0.6 and $0.05(\mu \mathrm{g} / \mathrm{mL})$ for naphthalene and benzo[a]pyrene metabolites respectively. (ND, not determined; $\mu \mathrm{g} / \mathrm{mL}$, micrograms per milliliter)—Continued

\begin{tabular}{|c|c|c|c|c|c|}
\hline Species & Fish ID & $\begin{array}{c}\text { Naphthalene } \\
(\mu \mathrm{g} / \mathrm{mL})\end{array}$ & $\begin{array}{c}\text { Benzo[a]pyrene } \\
(\mu \mathrm{g} / \mathrm{mL})\end{array}$ & $\begin{array}{c}\text { Naphthalene }^{1} \\
\text { ( } \mu \mathrm{g} / \mathrm{mL} \text { protein) }\end{array}$ & $\begin{array}{c}\text { Benzo[a]pyrene } \\
\text { ( } \mu \mathrm{g} / \mathrm{mL} \text { protein) }\end{array}$ \\
\hline White sucker & WS20 & 550 & 4.9 & 209.2 & 1.86 \\
\hline White sucker & WS21 & 370 & 8.3 & 75.4 & 1.69 \\
\hline White sucker & WS22 & ND & ND & ND & ND \\
\hline White sucker & WS23 & 1,600 & 36 & 167.8 & 3.77 \\
\hline White sucker & WS24 & 250 & 4.8 & 100.3 & 1.93 \\
\hline White sucker & WS25 & ND & ND & ND & ND \\
\hline White sucker & WS26 & 190 & 3.8 & 145.3 & 2.91 \\
\hline White sucker & WS27 & 400 & 11 & 70.5 & 1.94 \\
\hline White sucker & WS28 & 350 & 7.8 & 123.2 & 2.74 \\
\hline White sucker & WS29 & 470 & 10 & 107.1 & 2.28 \\
\hline White sucker & WS30 & 320 & 8 & 74.5 & 1.86 \\
\hline White sucker & WS31 & 280 & 6.9 & 66.2 & 1.63 \\
\hline White sucker & WS32 & 890 & 15 & 88.5 & 1.49 \\
\hline White sucker & WS33 & 830 & 15 & 141.4 & 2.56 \\
\hline White sucker & WS34 & 280 & 3.7 & 30.8 & 0.41 \\
\hline White sucker & WS35 & 210 & 4.2 & 66.5 & 1.33 \\
\hline White sucker & WS36 & 930 & 14 & 247 & 3.72 \\
\hline White sucker & WS37 & 610 & 12 & 105.4 & 2.07 \\
\hline White sucker & WS38 & 320 & 7.3 & 118.9 & 2.71 \\
\hline White sucker & WS39 & 380 & 8 & 65.1 & 1.37 \\
\hline White sucker & WS40 & 290 & 6.8 & 50.1 & 1.18 \\
\hline
\end{tabular}

${ }^{1} \mathrm{PAH}$ metabolite concentrations were normalized to protein content by a modified Lowry method.

${ }^{2}$ Sample was contaminated with other biological tissues resulting in having significantly higher levels of protein content. 
Table 21. Concentrations of contaminants (ng/g wet weight) in plasma from white suckers (WS), common carp (CC), and largemouth bass (LMB) collected from the Charles River (August, 2005). Concentrations determined from electron ionization gas chromatography/mass spectrometry. Analytes: Anthracene to d-Limonene. (MQL, method quantitation limit; ng/g, nanogram per gram; <, values below the detection level; BHA, Butylated Hydroxyanisole)

\begin{tabular}{|c|c|c|c|c|c|c|c|c|c|c|}
\hline Sample & Anthracene & Anthraquinone & BHA & Benzo(a)pyrene & Benzophenone & Bisphenol A & Caffeine & Cotinine & Cumene & d-Limonene \\
\hline MQL & 12.5 & 25 & 50 & 25 & 12.5 & 1,000 & 25 & 25 & 12.5 & 12.5 \\
\hline Blank 1 & $<12.5$ & $<25$ & $<50$ & $<12.5$ & $<12.5$ & $<1,000$ & $<25$ & $<25$ & $<12.5$ & $<12.5$ \\
\hline Blank 2 & $<12.5$ & $<25$ & $<50$ & $<12.5$ & $<12.5$ & $<1,000$ & $<25$ & $<25$ & $<12.5$ & $<12.5$ \\
\hline Blank 3 & $<12.5$ & $<25$ & $<50$ & $<12.5$ & $<12.5$ & $<1,000$ & $<25$ & $<25$ & $<12.5$ & $<12.5$ \\
\hline Blank 4 & $<12.5$ & $<25$ & $<50$ & $<12.5$ & $<12.5$ & $<1,000$ & $<25$ & $<25$ & $<12.5$ & $<12.5$ \\
\hline Blank 5 & $<12.5$ & $<25$ & $<50$ & $<12.5$ & $<12.5$ & $<1,000$ & $<25$ & $<25$ & $<12.5$ & $<12.5$ \\
\hline WS02 & $<12.5$ & $<25$ & $<50$ & $<12.5$ & 128.2 & $<1,000$ & $<25$ & $<25$ & $<12.5$ & $<12.5$ \\
\hline WS03 & $<12.5$ & $<25$ & $<50$ & $<12.5$ & 106.3 & $<1,000$ & $<25$ & $<25$ & $<12.5$ & $<12.5$ \\
\hline WS04(\#1) & $<12.5$ & $<25$ & $<50$ & $<12.5$ & $<12.5$ & $<1,000$ & $<25$ & $<25$ & $<12.5$ & $<12.5$ \\
\hline WS04(\#2) & $<12.5$ & $<25$ & $<50$ & $<12.5$ & 158.4 & $<1,000$ & $<25$ & $<25$ & $<12.5$ & $<12.5$ \\
\hline WS05 & $<12.5$ & $<25$ & $<50$ & $<12.5$ & $<12.5$ & $<1,000$ & $<25$ & $<25$ & $<12.5$ & $<12.5$ \\
\hline WS06(\#1) & $<12.5$ & $<25$ & $<50$ & $<12.5$ & $<12.5$ & $<1,000$ & $<25$ & $<25$ & $<12.5$ & $<12.5$ \\
\hline WS06(\#2) & $<12.5$ & $<25$ & $<50$ & $<12.5$ & 116.2 & $<1,000$ & $<25$ & $<25$ & $<12.5$ & $<12.5$ \\
\hline WS07(\#1) & $<12.5$ & $<25$ & $<50$ & $<12.5$ & $<12.5$ & $<1,000$ & $<25$ & $<25$ & $<12.5$ & $<12.5$ \\
\hline WS07(\#2) & $<12.5$ & $<25$ & $<50$ & $<12.5$ & 727.8 & $<1,000$ & $<25$ & $<25$ & $<12.5$ & $<12.5$ \\
\hline WS08(\#1) & $<12.5$ & $<25$ & $<50$ & $<12.5$ & $<12.5$ & $<1,000$ & $<25$ & $<25$ & $<12.5$ & $<12.5$ \\
\hline WS08(\#2) & $<12.5$ & $<25$ & $<50$ & $<12.5$ & $1,175.0$ & $<1,000$ & $<25$ & $<25$ & $<12.5$ & $<12.5$ \\
\hline WS09 & $<12.5$ & $<25$ & $<50$ & $<12.5$ & $<12.5$ & $<1,000$ & $<25$ & $<25$ & $<12.5$ & $<12.5$ \\
\hline WS11 & $<12.5$ & $<25$ & $<50$ & $<12.5$ & $<12.5$ & $<1,000$ & $<25$ & $<25$ & $<12.5$ & $<12.5$ \\
\hline WS12(\#1) & $<12.5$ & $<25$ & $<50$ & $<12.5$ & $<12.5$ & $<1,000$ & $<25$ & $<25$ & $<12.5$ & $<12.5$ \\
\hline WS12(\#2) & $<12.5$ & $<25$ & $<50$ & $<12.5$ & 191.2 & $<1,000$ & $<25$ & $<25$ & $<12.5$ & $<12.5$ \\
\hline WS13 & $<12.5$ & $<25$ & $<50$ & $<12.5$ & $<12.5$ & $<1,000$ & $<25$ & $<25$ & $<12.5$ & $<12.5$ \\
\hline WS16 & $<12.5$ & $<25$ & $<50$ & $<12.5$ & $<12.5$ & $<1,000$ & $<25$ & $<25$ & $<12.5$ & $<12.5$ \\
\hline WS17(\#1) & $<12.5$ & $<25$ & $<50$ & $<12.5$ & $<12.5$ & $<1,000$ & $<25$ & $<25$ & $<12.5$ & $<12.5$ \\
\hline WS17(\#2) & $<12.5$ & $<25$ & $<50$ & $<12.5$ & 1083.3 & $<1,000$ & $<25$ & $<25$ & $<12.5$ & $<12.5$ \\
\hline WS21(\#1) & $<12.5$ & $<25$ & $<50$ & $<12.5$ & $<12.5$ & $<1,000$ & $<25$ & $<25$ & $<12.5$ & $<12.5$ \\
\hline WS21(\#2) & $<12.5$ & $<25$ & $<50$ & $<12.5$ & 328.2 & $<1,000$ & $<25$ & $<25$ & $<12.5$ & $<12.5$ \\
\hline WS23 & $<12.5$ & $<25$ & $<50$ & $<12.5$ & $<12.5$ & $<1,000$ & $<25$ & $<25$ & $<12.5$ & $<12.5$ \\
\hline WS26 & $<12.5$ & $<25$ & $<50$ & $<12.5$ & $<12.5$ & $<1,000$ & $<25$ & $<25$ & $<12.5$ & $<12.5$ \\
\hline
\end{tabular}


Table 21. Concentrations of contaminants (ng/g wet weight) in plasma from white suckers (WS), common carp (CC), and largemouth bass (LMB) collected from the Charles River (August, 2005). Concentrations determined from electron ionization gas chromatography/mass spectrometry. Analytes: Anthracene to d-Limonene. (MQL, method quantitation limit; ng/g, nanogram per gram; <, values below the detection level; BHA, Butylated Hydroxyanisole)-Continued

\begin{tabular}{|c|c|c|c|c|c|c|c|c|c|c|}
\hline Sample & Anthracene & Anthraquinone & BHA & Benzo(a)pyrene & Benzophenone & Bisphenol A & Caffeine & Cotinine & Cumene & d-Limonene \\
\hline WS27(\#1) & $<12.5$ & $<25$ & $<50$ & $<12.5$ & $<12.5$ & $<1,000$ & $<25$ & $<25$ & $<12.5$ & $<12.5$ \\
\hline WS27(\#2) & $<12.5$ & $<25$ & $<50$ & $<12.5$ & 128.1 & $<1,000$ & $<25$ & $<25$ & $<12.5$ & $<12.5$ \\
\hline WS30(\#1) & $<12.5$ & $<25$ & $<50$ & $<12.5$ & $<12.5$ & $<1,000$ & $<25$ & $<25$ & $<12.5$ & $<12.5$ \\
\hline WS30(\#2) & $<12.5$ & $<25$ & $<50$ & $<12.5$ & $<12.5$ & $<1,000$ & $<25$ & $<25$ & $<12.5$ & $<12.5$ \\
\hline WS35 & $<12.5$ & $<25$ & $<50$ & $<12.5$ & 313.9 & $<1,000$ & $<25$ & $<25$ & $<12.5$ & $<12.5$ \\
\hline WS36 & $<12.5$ & $<25$ & $<50$ & $<12.5$ & $<12.5$ & $<1,000$ & $<25$ & $<25$ & $<12.5$ & $<12.5$ \\
\hline WS37 & $<12.5$ & $<25$ & $<50$ & $<12.5$ & 289.7 & $<1,000$ & $<25$ & $<25$ & $<12.5$ & $<12.5$ \\
\hline WS39 & $<12.5$ & $<25$ & $<50$ & $<12.5$ & $<12.5$ & $<1,000$ & $<25$ & $<25$ & $<12.5$ & $<12.5$ \\
\hline $\mathrm{CC} 01$ & $<12.5$ & $<25$ & $<50$ & $<12.5$ & 71.7 & $<1,000$ & $<25$ & $<25$ & $<12.5$ & 33.3 \\
\hline $\mathrm{CC} 02$ & $<12.5$ & $<25$ & $<50$ & $<12.5$ & $<12.5$ & $<1,000$ & $<25$ & $<25$ & $<12.5$ & $<12.5$ \\
\hline $\mathrm{CC} 04$ & $<12.5$ & $<25$ & $<50$ & $<12.5$ & 103.6 & $<1,000$ & $<25$ & $<25$ & $<12.5$ & $<12.5$ \\
\hline $\mathrm{CC} 05$ & $<12.5$ & $<25$ & $<50$ & $<12.5$ & $<12.5$ & $<1,000$ & $<25$ & $<25$ & $<12.5$ & $<12.5$ \\
\hline $\mathrm{CC} 07$ & $<12.5$ & $<25$ & $<50$ & $<12.5$ & $<12.5$ & $<1,000$ & $<25$ & $<25$ & $<12.5$ & $<12.5$ \\
\hline CC09 & $<12.5$ & $<25$ & $<50$ & $<12.5$ & 108.0 & $<1,000$ & $<25$ & $<25$ & $<12.5$ & $<12.5$ \\
\hline $\mathrm{CC} 10$ & $<12.5$ & $<25$ & $<50$ & $<12.5$ & $<12.5$ & $<1,000$ & $<25$ & $<25$ & $<12.5$ & $<12.5$ \\
\hline $\mathrm{CC} 13$ & $<12.5$ & $<25$ & $<50$ & $<12.5$ & $<12.5$ & $<1,000$ & $<25$ & $<25$ & $<12.5$ & 39.4 \\
\hline $\mathrm{CC} 16$ & $<12.5$ & $<25$ & $<50$ & $<12.5$ & $<12.5$ & $<1,000$ & $<25$ & $<25$ & $<12.5$ & $<12.5$ \\
\hline $\mathrm{CC} 17$ & $<12.5$ & $<25$ & $<50$ & $<12.5$ & 107.3 & $<1,000$ & $<25$ & $<25$ & $<12.5$ & $<12.5$ \\
\hline LMB01 & $<12.5$ & $<25$ & $<50$ & $<12.5$ & 126.7 & $<1,000$ & $<25$ & $<25$ & $<12.5$ & $<12.5$ \\
\hline LMB02 & $<12.5$ & $<25$ & $<50$ & $<12.5$ & 116.8 & $<1,000$ & $<25$ & $<25$ & $<12.5$ & 39.0 \\
\hline LMB05 & $<12.5$ & $<25$ & $<50$ & $<12.5$ & 125.0 & $<1,000$ & $<25$ & $<25$ & $<12.5$ & 133.7 \\
\hline LMB12 & $<12.5$ & $<25$ & $<50$ & $<12.5$ & 167.6 & $<1,000$ & $<25$ & $<25$ & $<12.5$ & $<12.5$ \\
\hline
\end{tabular}


Table 21. Concentrations of contaminants (ng/g wet weight) in plasma from white suckers (WS), common carp (CC), and largemouth bass (LMB) collected from the Charles River (August, 2005). Concentrations determined from electron ionization gas chromatography/mass spectrometry. Analytes: Equilenin to Menthol. (MQL, method quantitation limit; ng/g, nanogram per gram; <, values below the detection level; BHA, Butylated Hydroxyanisole) -Continued

\begin{tabular}{|c|c|c|c|c|c|c|c|c|c|}
\hline Sample & Equilenin & Fluoranthene & Galoxolide (HHCB) & Indole & Isoborneol & Isophorone & Isoquinoline & Metalaxyl & Menthol \\
\hline MQL & 500 & 25 & 25 & 12.5 & 25 & 12.5 & 12.5 & 50 & 25 \\
\hline Blank 1 & $<500$ & $<25$ & $<25$ & $<12.5$ & $<25$ & $<12.5$ & $<12.5$ & $<50$ & $<25$ \\
\hline Blank 2 & $<500$ & $<25$ & $<25$ & $<12.5$ & $<25$ & $<12.5$ & $<12.5$ & $<50$ & $<25$ \\
\hline Blank 3 & $<500$ & $<25$ & $<25$ & $<12.5$ & $<25$ & $<12.5$ & $<12.5$ & $<50$ & $<25$ \\
\hline Blank 4 & $<500$ & $<25$ & $<25$ & $<12.5$ & $<25$ & $<12.5$ & $<12.5$ & $<50$ & $<25$ \\
\hline Blank 5 & $<500$ & $<25$ & $<25$ & $<12.5$ & $<25$ & $<12.5$ & $<12.5$ & $<50$ & $<25$ \\
\hline WS02 & $<500$ & $<25$ & $<25$ & $<12.5$ & $<25$ & $<12.5$ & $<12.5$ & $<50$ & $<25$ \\
\hline WS04(\#1) & $<500$ & $<25$ & $<25$ & $<12.5$ & $<25$ & $<12.5$ & $<12.5$ & $<50$ & $<25$ \\
\hline WS04(\#2) & $<500$ & $<25$ & $<25$ & $<12.5$ & $<25$ & $<12.5$ & $<12.5$ & $<50$ & $<25$ \\
\hline WS05 & $<500$ & $<25$ & $<25$ & $<12.5$ & $<25$ & $<12.5$ & $<12.5$ & $<50$ & $<25$ \\
\hline WS06(\#1) & $<500$ & $<25$ & $<25$ & $<12.5$ & $<25$ & $<12.5$ & $<12.5$ & $<50$ & $<25$ \\
\hline WS06(\#2) & $<500$ & $<25$ & $<25$ & $<12.5$ & $<25$ & $<12.5$ & $<12.5$ & $<50$ & $<25$ \\
\hline WS07(\#1) & $<500$ & $<25$ & $<25$ & $<12.5$ & $<25$ & $<12.5$ & $<12.5$ & $<50$ & $<25$ \\
\hline WS07(\#2) & $<500$ & $<25$ & $<25$ & $<12.5$ & $<25$ & $<12.5$ & $<12.5$ & $<50$ & $<25$ \\
\hline WS08(\#2) & $<500$ & $<25$ & $<25$ & $<12.5$ & $<25$ & $<12.5$ & $<12.5$ & $<50$ & $<25$ \\
\hline WS09 & $<500$ & $<25$ & $<25$ & $<12.5$ & $<25$ & $<12.5$ & $<12.5$ & $<50$ & $<25$ \\
\hline WS11 & $<500$ & $<25$ & $<25$ & $<12.5$ & $<25$ & $<12.5$ & $<12.5$ & $<50$ & $<25$ \\
\hline WS12(\#1) & $<500$ & $<25$ & $<25$ & $<12.5$ & $<25$ & $<12.5$ & $<12.5$ & $<50$ & $<25$ \\
\hline WS12(\#2) & $<500$ & $<25$ & $<25$ & $<12.5$ & $<25$ & $<12.5$ & $<12.5$ & $<50$ & $<25$ \\
\hline WS13 & $<500$ & $<25$ & $<25$ & $<12.5$ & $<25$ & $<12.5$ & $<12.5$ & $<50$ & $<25$ \\
\hline WS16 & $<500$ & $<25$ & $<25$ & $<12.5$ & $<25$ & $<12.5$ & $<12.5$ & $<50$ & $<25$ \\
\hline WS17(\#1) & $<500$ & $<25$ & $<25$ & $<12.5$ & $<25$ & $<12.5$ & $<12.5$ & $<50$ & $<25$ \\
\hline WS17(\#2) & $<500$ & $<25$ & $<25$ & $<12.5$ & $<25$ & $<12.5$ & $<12.5$ & $<50$ & $<25$ \\
\hline WS21(\#1) & $<500$ & $<25$ & $<25$ & $<12.5$ & $<25$ & $<12.5$ & $<12.5$ & $<50$ & $<25$ \\
\hline WS21(\#2) & $<500$ & $<25$ & $<25$ & $<12.5$ & $<25$ & $<12.5$ & $<12.5$ & $<50$ & $<25$ \\
\hline WS23 & $<500$ & $<25$ & $<25$ & $<12.5$ & $<25$ & $<12.5$ & $<12.5$ & $<50$ & $<25$ \\
\hline WS26 & $<500$ & $<25$ & $<25$ & $<12.5$ & $<25$ & $<12.5$ & $<12.5$ & $<50$ & $<25$ \\
\hline WS27(\#1) & $<500$ & $<25$ & $<25$ & $<12.5$ & $<25$ & $<12.5$ & $<12.5$ & $<50$ & $<25$ \\
\hline WS27(\#2) & $<500$ & $<25$ & $<25$ & $<12.5$ & $<25$ & $<12.5$ & $<12.5$ & $<50$ & $<25$ \\
\hline
\end{tabular}


Table 21. Concentrations of contaminants ( $\mathrm{ng} / \mathrm{g}$ wet weight) in plasma from white suckers (WS), common carp (CC), and largemouth bass (LMB) collected from the Charles River (August, 2005). Concentrations determined from electron ionization gas chromatography/mass spectrometry. Analytes: Equilenin to Menthol. (MQL, method quantitation limit; ng/g, nanogram per gram; <, values below the detection level; BHA, Butylated Hydroxyanisole) -Continued

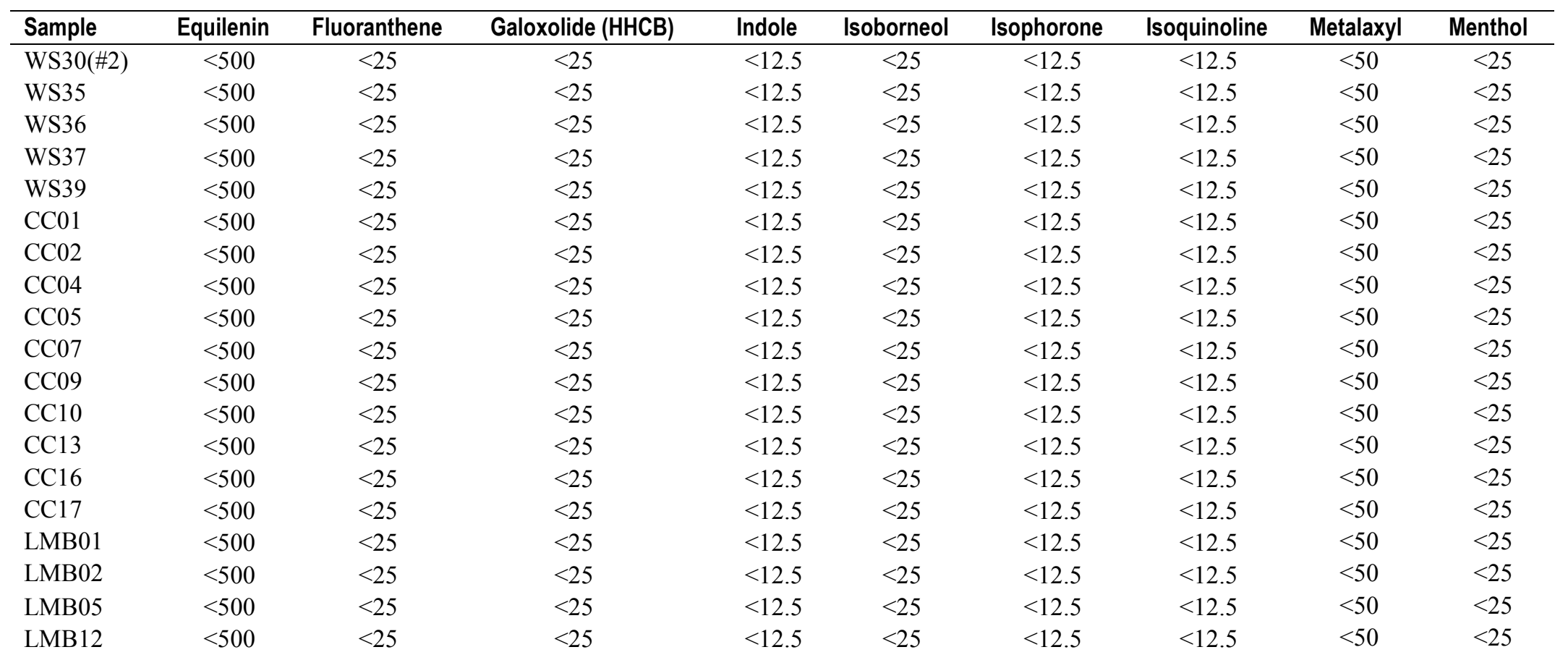


Table 21. Concentrations of contaminants (ng/g wet weight) in plasma from white suckers (WS), common carp (CC), and largemouth bass (LMB) collected from the Charles River (August, 2005). Concentrations determined from electron ionization gas chromatography/mass spectrometry. Analytes: Methyl salicylate to Penta-chlorophenol. (MQL, method quantitation limit; ng/g, nanogram per gram; <, values below the detection level; BHA, Butylated Hydroxyanisole)—Continued

\begin{tabular}{|c|c|c|c|c|c|c|c|c|c|}
\hline Sample & $\begin{array}{c}\text { Methyl } \\
\text { salicylate }\end{array}$ & Naphthalene & NPEO-1 & NPEO-2 & OPEO & Oxybenzone & Para-cresol & Para-nonylphenol & $\begin{array}{c}\text { Penta- } \\
\text { chlorophenol }\end{array}$ \\
\hline MQL & 12.5 & 12.5 & 1,000 & 1,000 & 500 & 25 & 12.5 & 1,000 & 250 \\
\hline Blank 1 & $<12.5$ & $<12.5$ & $<1,000$ & $<1,000$ & $<500$ & $<25$ & 12.5 & $<1,000$ & $<250$ \\
\hline Blank 2 & $<12.5$ & $<12.5$ & $<1,000$ & $<1,000$ & $<500$ & $<25$ & 12.5 & $<1,000$ & $<250$ \\
\hline Blank 3 & $<12.5$ & $<12.5$ & $<1,000$ & $<1,000$ & $<500$ & $<25$ & 12.5 & $<1,000$ & $<250$ \\
\hline Blank 4 & $<12.5$ & $<12.5$ & $<1,000$ & $<1,000$ & $<500$ & $<25$ & 12.5 & $<1,000$ & $<250$ \\
\hline Blank 5 & $<12.5$ & $<12.5$ & $<1,000$ & $<1,000$ & $<500$ & $<25$ & 12.5 & $<1,000$ & $<250$ \\
\hline WS02 & $<12.5$ & $<12.5$ & $<1,000$ & $<1,000$ & $<500$ & $<25$ & 12.5 & $<1,000$ & $<250$ \\
\hline WS03 & $<12.5$ & $<12.5$ & $<1,000$ & $<1,000$ & $<500$ & $<25$ & 12.5 & $<1,000$ & $<250$ \\
\hline WS04(\#1) & $<12.5$ & $<12.5$ & $<1,000$ & $<1,000$ & $<500$ & $<25$ & 12.5 & $<1,000$ & $<250$ \\
\hline WS04(\#2) & $<12.5$ & $<12.5$ & $<1,000$ & $<1,000$ & $<500$ & $<25$ & 12.5 & $<1,000$ & $<250$ \\
\hline WS05 & $<12.5$ & $<12.5$ & $<1,000$ & $<1,000$ & $<500$ & $<25$ & 12.5 & $<1,000$ & $<250$ \\
\hline WS06(\#1) & $<12.5$ & $<12.5$ & $<1,000$ & $<1,000$ & $<500$ & $<25$ & 12.5 & $<1,000$ & $<250$ \\
\hline WS06(\#2) & $<12.5$ & $<12.5$ & $<1,000$ & $<1,000$ & $<500$ & $<25$ & 12.5 & $<1,000$ & $<250$ \\
\hline WS07(\#1) & $<12.5$ & $<12.5$ & $<1,000$ & $<1,000$ & $<500$ & $<25$ & 12.5 & $<1,000$ & $<250$ \\
\hline WS07(\#2) & $<12.5$ & $<12.5$ & $<1,000$ & $<1,000$ & $<500$ & $<25$ & 12.5 & $<1,000$ & $<250$ \\
\hline WS08(\#1) & $<12.5$ & $<12.5$ & $<1,000$ & $<1,000$ & $<500$ & $<25$ & 12.5 & $<1,000$ & $<250$ \\
\hline WS08(\#2) & $<12.5$ & $<12.5$ & $<1,000$ & $<1,000$ & $<500$ & $<25$ & 12.5 & $<1,000$ & $<250$ \\
\hline WS09 & $<12.5$ & $<12.5$ & $<1,000$ & $<1,000$ & $<500$ & $<25$ & 12.5 & $<1,000$ & $<250$ \\
\hline WS11 & $<12.5$ & $<12.5$ & $<1,000$ & $<1,000$ & $<500$ & $<25$ & 12.5 & $<1,000$ & $<250$ \\
\hline WS12(\#1) & $<12.5$ & $<12.5$ & $<1,000$ & $<1,000$ & $<500$ & $<25$ & 12.5 & $<1,000$ & $<250$ \\
\hline WS12(\#2) & $<12.5$ & $<12.5$ & $<1,000$ & $<1,000$ & $<500$ & $<25$ & 12.5 & $<1,000$ & $<250$ \\
\hline WS13 & $<12.5$ & $<12.5$ & $<1,000$ & $<1,000$ & $<500$ & $<25$ & 12.5 & $<1,000$ & $<250$ \\
\hline WS16 & $<12.5$ & $<12.5$ & $<1,000$ & $<1,000$ & $<500$ & $<25$ & 12.5 & $<1,000$ & $<250$ \\
\hline WS17(\#1) & $<12.5$ & $<12.5$ & $<1,000$ & $<1,000$ & $<500$ & $<25$ & 12.5 & $<1,000$ & $<250$ \\
\hline WS17(\#2) & $<12.5$ & $<12.5$ & $<1,000$ & $<1,000$ & $<500$ & $<25$ & 12.5 & $<1,000$ & $<250$ \\
\hline WS21(\#1) & $<12.5$ & $<12.5$ & $<1,000$ & $<1,000$ & $<500$ & $<25$ & 12.5 & $<1,000$ & $<250$ \\
\hline WS21(\#2) & $<12.5$ & $<12.5$ & $<1,000$ & $<1,000$ & $<500$ & $<25$ & 12.5 & $<1,000$ & $<250$ \\
\hline WS23 & $<12.5$ & $<12.5$ & $<1,000$ & $<1,000$ & $<500$ & $<25$ & 12.5 & $<1,000$ & $<250$ \\
\hline
\end{tabular}


Table 21. Concentrations of contaminants (ng/g wet weight) in plasma from white suckers (WS), common carp (CC), and largemouth bass (LMB) collected from the Charles River (August, 2005). Concentrations determined from electron ionization gas chromatography/mass spectrometry. Analytes: Methyl salicylate to Penta-chlorophenol. (MQL, method quantitation limit; ng/g, nanogram per gram; <, values below the detection level; BHA, Butylated Hydroxyanisole)—Continued

\begin{tabular}{|c|c|c|c|c|c|c|c|c|c|}
\hline Sample & $\begin{array}{c}\text { Methyl } \\
\text { salicylate }\end{array}$ & Naphthalene & NPEO-1 & NPEO-2 & OPEO & Oxybenzone & Para-cresol & Para-nonylphenol & $\begin{array}{c}\text { Penta- } \\
\text { chlorophenol }\end{array}$ \\
\hline WS26 & $<12.5$ & $<12.5$ & $<1,000$ & $<1,000$ & $<500$ & $<25$ & 12.5 & $<1,000$ & $<250$ \\
\hline WS27(\#1) & $<12.5$ & $<12.5$ & $<1,000$ & $<1,000$ & $<500$ & $<25$ & 12.5 & $<1,000$ & $<250$ \\
\hline WS27(\#2) & $<12.5$ & $<12.5$ & $<1,000$ & $<1,000$ & $<500$ & $<25$ & 12.5 & $<1,000$ & $<250$ \\
\hline WS30(\#1) & $<12.5$ & $<12.5$ & $<1,000$ & $<1,000$ & $<500$ & $<25$ & 12.5 & $<1,000$ & $<250$ \\
\hline WS30(\#2) & $<12.5$ & $<12.5$ & $<1,000$ & $<1,000$ & $<500$ & $<25$ & 12.5 & $<1,000$ & $<250$ \\
\hline WS35 & $<12.5$ & $<12.5$ & $<1,000$ & $<1,000$ & $<500$ & $<25$ & 12.5 & $<1,000$ & $<250$ \\
\hline WS36 & $<12.5$ & $<12.5$ & $<1,000$ & $<1,000$ & $<500$ & $<25$ & 12.5 & $<1,000$ & $<250$ \\
\hline WS37 & $<12.5$ & $<12.5$ & $<1,000$ & $<1,000$ & $<500$ & $<25$ & 12.5 & $<1,000$ & $<250$ \\
\hline WS39 & $<12.5$ & $<12.5$ & $<1,000$ & $<1,000$ & $<500$ & $<25$ & 12.5 & $<1,000$ & $<250$ \\
\hline $\mathrm{CC} 01$ & $<12.5$ & $<12.5$ & $<1,000$ & $<1,000$ & $<500$ & $<25$ & 12.5 & $<1,000$ & $<250$ \\
\hline $\mathrm{CC} 02$ & $<12.5$ & $<12.5$ & $<1,000$ & $<1,000$ & $<500$ & $<25$ & 12.5 & $<1,000$ & $<250$ \\
\hline $\mathrm{CC} 04$ & $<12.5$ & $<12.5$ & $<1,000$ & $<1,000$ & $<500$ & $<25$ & 12.5 & $<1,000$ & $<250$ \\
\hline $\mathrm{CC} 05$ & $<12.5$ & $<12.5$ & $<1,000$ & $<1,000$ & $<500$ & $<25$ & 12.5 & $<1,000$ & $<250$ \\
\hline $\mathrm{CC} 07$ & $<12.5$ & $<12.5$ & $<1,000$ & $<1,000$ & $<500$ & $<25$ & 12.5 & $<1,000$ & $<250$ \\
\hline $\mathrm{CC} 09$ & $<12.5$ & $<12.5$ & $<1,000$ & $<1,000$ & $<500$ & $<25$ & 12.5 & $<1,000$ & $<250$ \\
\hline $\mathrm{CC} 10$ & $<12.5$ & $<12.5$ & $<1,000$ & $<1,000$ & $<500$ & $<25$ & 12.5 & $<1,000$ & $<250$ \\
\hline $\mathrm{CC} 13$ & $<12.5$ & $<12.5$ & $<1,000$ & $<1,000$ & $<500$ & $<25$ & 12.5 & $<1,000$ & $<250$ \\
\hline $\mathrm{CC} 16$ & $<12.5$ & $<12.5$ & $<1,000$ & $<1,000$ & $<500$ & $<25$ & 12.5 & $<1,000$ & $<250$ \\
\hline $\mathrm{CC} 17$ & $<12.5$ & $<12.5$ & $<1,000$ & $<1,000$ & $<500$ & $<25$ & 12.5 & $<1,000$ & $<250$ \\
\hline LMB01 & $<12.5$ & $<12.5$ & $<1,000$ & $<1,000$ & $<500$ & $<25$ & 12.5 & $<1,000$ & $<250$ \\
\hline LMB02 & $<12.5$ & $<12.5$ & $<1,000$ & $<1,000$ & $<500$ & $<25$ & 12.5 & $<1,000$ & $<250$ \\
\hline LMB05 & $<12.5$ & $<12.5$ & $<1,000$ & $<1,000$ & $<500$ & $<25$ & 12.5 & $<1,000$ & $<250$ \\
\hline LMB12 & $<12.5$ & $<12.5$ & $<1,000$ & $<1,000$ & $<500$ & $<25$ & 12.5 & $<1,000$ & $<250$ \\
\hline
\end{tabular}


Table 21. Concentrations of contaminants (ng/g wet weight) in plasma from white suckers (WS), common carp (CC), and largemouth bass (LMB) collected from the Charles River (August, 2005). Concentrations determined from electron ionization gas chromatography/mass spectrometry. Analytes: Phenanthrene to Triphenyl phosphate. (MQL, method quantitation limit; ng/g, nanogram per gram; <, values below the detection level; BHA, Butylated Hydroxyanisole)-Continued

\begin{tabular}{|c|c|c|c|c|c|c|c|c|}
\hline Sample & Phenanthrene & Pyrene & $\begin{array}{c}\text { Tonalide } \\
\text { (AHTN) }\end{array}$ & $\begin{array}{c}\text { tris-(2-Chloroethyl)- } \\
\text { phosphate }\end{array}$ & $\begin{array}{c}\text { tris (2-Butoxyethyl)- } \\
\text { phosphate }\end{array}$ & $\begin{array}{l}\text { Tributyl- } \\
\text { phosphate }\end{array}$ & $\begin{array}{l}\text { Triclosan } \\
\text { (Irgesan) }\end{array}$ & $\begin{array}{l}\text { Triphenyl } \\
\text { phosphate }\end{array}$ \\
\hline MQL & 12.5 & 25 & 25 & 50 & 50 & 12.5 & 500 & 12.5 \\
\hline Blank 1 & $<12.5$ & $<25$ & $<25$ & $<50$ & $<50$ & $<12.5$ & $<500$ & $<12.5$ \\
\hline Blank 2 & $<12.5$ & $<25$ & $<25$ & $<50$ & $<50$ & $<12.5$ & $<500$ & $<12.5$ \\
\hline Blank 3 & $<12.5$ & $<25$ & $<25$ & $<50$ & $<50$ & $<12.5$ & $<500$ & $<12.5$ \\
\hline Blank 4 & $<12.5$ & $<25$ & $<25$ & $<50$ & $<50$ & $<12.5$ & $<500$ & $<12.5$ \\
\hline Blank 5 & $<12.5$ & $<25$ & $<25$ & $<50$ & $<50$ & $<12.5$ & $<500$ & $<12.5$ \\
\hline WS02 & $<12.5$ & $<25$ & $<25$ & $<50$ & $<50$ & $<12.5$ & $<500$ & $<12.5$ \\
\hline WS03 & $<12.5$ & $<25$ & $<25$ & $<50$ & $<50$ & $<12.5$ & $<500$ & $<12.5$ \\
\hline WS04(\#1) & $<12.5$ & $<25$ & $<25$ & $<50$ & $<50$ & $<12.5$ & $<500$ & $<12.5$ \\
\hline WS04(\#2) & $<12.5$ & $<25$ & $<25$ & $<50$ & $<50$ & $<12.5$ & $<500$ & $<12.5$ \\
\hline WS05 & $<12.5$ & $<25$ & $<25$ & $<50$ & $<50$ & $<12.5$ & $<500$ & $<12.5$ \\
\hline WS06(\#1) & $<12.5$ & $<25$ & $<25$ & $<50$ & $<50$ & $<12.5$ & $<500$ & $<12.5$ \\
\hline WS06(\#2) & $<12.5$ & $<25$ & $<25$ & $<50$ & $<50$ & $<12.5$ & $<500$ & $<12.5$ \\
\hline WS07(\#1) & $<12.5$ & $<25$ & $<25$ & $<50$ & $<50$ & $<12.5$ & $<500$ & $<12.5$ \\
\hline WS07(\#2) & $<12.5$ & $<25$ & $<25$ & $<50$ & $<50$ & $<12.5$ & $<500$ & $<12.5$ \\
\hline WS08(\#1) & $<12.5$ & $<25$ & $<25$ & $<50$ & $<50$ & $<12.5$ & $<500$ & $<12.5$ \\
\hline WS08(\#2) & $<12.5$ & $<25$ & $<25$ & $<50$ & $<50$ & $<12.5$ & $<500$ & $<12.5$ \\
\hline WS09 & $<12.5$ & $<25$ & $<25$ & $<50$ & $<50$ & $<12.5$ & $<500$ & $<12.5$ \\
\hline WS11 & $<12.5$ & $<25$ & $<25$ & $<50$ & $<50$ & $<12.5$ & $<500$ & $<12.5$ \\
\hline WS12(\#1) & $<12.5$ & $<25$ & $<25$ & $<50$ & $<50$ & $<12.5$ & $<500$ & $<12.5$ \\
\hline WS12(\#2) & $<12.5$ & $<25$ & $<25$ & $<50$ & $<50$ & $<12.5$ & $<500$ & $<12.5$ \\
\hline WS13 & $<12.5$ & $<25$ & $<25$ & $<50$ & $<50$ & $<12.5$ & $<500$ & $<12.5$ \\
\hline WS16 & $<12.5$ & $<25$ & $<25$ & $<50$ & $<50$ & $<12.5$ & $<500$ & $<12.5$ \\
\hline WS17(\#1) & $<12.5$ & $<25$ & $<25$ & $<50$ & $<50$ & $<12.5$ & $<500$ & $<12.5$ \\
\hline WS17(\#2) & $<12.5$ & $<25$ & $<25$ & $<50$ & $<50$ & $<12.5$ & $<500$ & $<12.5$ \\
\hline WS21(\#1) & $<12.5$ & $<25$ & $<25$ & $<50$ & $<50$ & $<12.5$ & $<500$ & $<12.5$ \\
\hline WS21(\#2) & $<12.5$ & $<25$ & $<25$ & $<50$ & $<50$ & $<12.5$ & $<500$ & $<12.5$ \\
\hline WS23 & $<12.5$ & $<25$ & $<25$ & $<50$ & $<50$ & $<12.5$ & $<500$ & $<12.5$ \\
\hline
\end{tabular}


Table 21. Concentrations of contaminants (ng/g wet weight) in plasma from white suckers (WS), common carp (CC), and largemouth bass (LMB) collected from the Charles River (August, 2005). Concentrations determined from electron ionization gas chromatography/mass spectrometry. Analytes: Phenanthrene to Triphenyl phosphate. (MQL, method quantitation limit; ng/g, nanogram per gram; <, values below the detection level; BHA, Butylated Hydroxyanisole)-Continued

\begin{tabular}{|c|c|c|c|c|c|c|c|c|}
\hline Sample & Phenanthrene & Pyrene & $\begin{array}{c}\text { Tonalide } \\
\text { (AHTN) }\end{array}$ & $\begin{array}{l}\text { tris-(2-Chloroethyl)- } \\
\text { phosphate }\end{array}$ & $\begin{array}{c}\text { tris (2-Butoxyethyl)- } \\
\text { phosphate }\end{array}$ & $\begin{array}{c}\text { Tributyl- } \\
\text { phosphate }\end{array}$ & $\begin{array}{l}\text { Triclosan } \\
\text { (Irgesan) }\end{array}$ & $\begin{array}{c}\text { Triphenyl } \\
\text { phosphate }\end{array}$ \\
\hline WS26 & $<12.5$ & $<25$ & $<25$ & $<50$ & $<50$ & $<12.5$ & $<500$ & $<12.5$ \\
\hline WS27(\#1) & $<12.5$ & $<25$ & $<25$ & $<50$ & $<50$ & $<12.5$ & $<500$ & $<12.5$ \\
\hline WS27(\#2) & $<12.5$ & $<25$ & $<25$ & $<50$ & $<50$ & $<12.5$ & $<500$ & $<12.5$ \\
\hline WS30(\#1) & $<12.5$ & $<25$ & $<25$ & $<50$ & $<50$ & $<12.5$ & $<500$ & $<12.5$ \\
\hline WS30(\#2) & $<12.5$ & $<25$ & $<25$ & $<50$ & $<50$ & $<12.5$ & $<500$ & $<12.5$ \\
\hline WS35 & $<12.5$ & $<25$ & $<25$ & $<50$ & $<50$ & $<12.5$ & $<500$ & $<12.5$ \\
\hline WS36 & $<12.5$ & $<25$ & $<25$ & $<50$ & $<50$ & $<12.5$ & $<500$ & $<12.5$ \\
\hline WS37 & $<12.5$ & $<25$ & $<25$ & $<50$ & $<50$ & $<12.5$ & $<500$ & $<12.5$ \\
\hline WS39 & $<12.5$ & $<25$ & $<25$ & $<50$ & $<50$ & $<12.5$ & $<500$ & $<12.5$ \\
\hline $\mathrm{CC} 01$ & $<12.5$ & $<25$ & $<25$ & $<50$ & $<50$ & $<12.5$ & $<500$ & $<12.5$ \\
\hline $\mathrm{CC} 02$ & $<12.5$ & $<25$ & $<25$ & $<50$ & $<50$ & $<12.5$ & $<500$ & $<12.5$ \\
\hline $\mathrm{CC} 04$ & $<12.5$ & $<25$ & $<25$ & $<50$ & $<50$ & $<12.5$ & $<500$ & $<12.5$ \\
\hline $\mathrm{CC} 05$ & $<12.5$ & $<25$ & $<25$ & $<50$ & $<50$ & $<12.5$ & $<500$ & $<12.5$ \\
\hline $\mathrm{CC} 07$ & $<12.5$ & $<25$ & $<25$ & $<50$ & $<50$ & $<12.5$ & $<500$ & $<12.5$ \\
\hline $\mathrm{CC} 09$ & $<12.5$ & $<25$ & $<25$ & $<50$ & $<50$ & $<12.5$ & $<500$ & $<12.5$ \\
\hline $\mathrm{CC} 10$ & $<12.5$ & $<25$ & $<25$ & $<50$ & $<50$ & $<12.5$ & $<500$ & $<12.5$ \\
\hline $\mathrm{CC} 13$ & $<12.5$ & $<25$ & $<25$ & $<50$ & $<50$ & $<12.5$ & $<500$ & $<12.5$ \\
\hline $\mathrm{CC} 16$ & $<12.5$ & $<25$ & $<25$ & $<50$ & $<50$ & $<12.5$ & $<500$ & $<12.5$ \\
\hline CC17 & $<12.5$ & $<25$ & $<25$ & $<50$ & $<50$ & $<12.5$ & $<500$ & $<12.5$ \\
\hline LMB01 & 96.2 & 70.9 & $<25$ & $<50$ & $<50$ & $<12.5$ & $<500$ & $<12.5$ \\
\hline LMB02 & $<12.5$ & $<25$ & $<25$ & $<50$ & $<50$ & $<12.5$ & $<500$ & $<12.5$ \\
\hline LMB05 & 35.9 & 40.0 & $<25$ & $<50$ & $<50$ & $<12.5$ & $<500$ & $<12.5$ \\
\hline LMB12 & $<12.5$ & $<25$ & $<25$ & $<50$ & $<50$ & $<12.5$ & $<500$ & $<12.5$ \\
\hline
\end{tabular}


Table 21. Concentrations of contaminants (ng/g wet weight) in plasma from white suckers (WS), common carp (CC), and largemouth bass (LMB) collected from the Charles River (August, 2005). Concentrations determined from electron ionization gas chromatography/mass spectrometry.

Analytes: 2-Methyl naphthalene to 4-Cumylphenol. (MQL, method quantitation limit; ng/g, nanogram per gram; <, values below the detection level; BHA, Butylated Hydroxyanisole) - Continued

\begin{tabular}{|c|c|c|c|c|c|c|c|c|c|}
\hline Sample & $\begin{array}{c}\text { 2-Methyl } \\
\text { naphthalene }\end{array}$ & $\begin{array}{c}\text { 3,4-Dichlorophenyl } \\
\text { isocyanate }\end{array}$ & $\begin{array}{c}\text { 1-Methyl } \\
\text { naphthalene }\end{array}$ & $\begin{array}{l}\text { 3-Methyl-1(H)- } \\
\text { indole (skatol) }\end{array}$ & $\begin{array}{l}\text { 2,6-Dimethyl } \\
\text { naphthalene }\end{array}$ & $\begin{array}{l}5 \text {-Methyl-1H- } \\
\text { benzotriazole }\end{array}$ & $\begin{array}{c}\text { 4-Tert- } \\
\text { octylphenol }\end{array}$ & $\begin{array}{c}\text { 4- } \\
\text { Octylphenol }\end{array}$ & $\begin{array}{c}\text { 4- } \\
\text { Cumylphenol }\end{array}$ \\
\hline MQL & 12.5 & 500 & 12.5 & 12.5 & 12.5 & 250.0 & 125.0 & 125.0 & 125.0 \\
\hline Blank 1 & $<12.5$ & $<500$ & $<12.5$ & $<12.5$ & $<12.5$ & $<250$ & $<125$ & $<125$ & $<125$ \\
\hline Blank 2 & $<12.5$ & $<500$ & $<12.5$ & $<12.5$ & $<12.5$ & $<250$ & $<125$ & $<125$ & $<125$ \\
\hline Blank 3 & $<12.5$ & $<500$ & $<12.5$ & $<12.5$ & $<12.5$ & $<250$ & $<125$ & $<125$ & $<125$ \\
\hline Blank 4 & $<12.5$ & $<500$ & $<12.5$ & $<12.5$ & $<12.5$ & $<250$ & $<125$ & $<125$ & $<125$ \\
\hline Blank 5 & $<12.5$ & $<500$ & $<12.5$ & $<12.5$ & $<12.5$ & $<250$ & $<125$ & $<125$ & $<125$ \\
\hline WS02 & $<12.5$ & $<500$ & $<12.5$ & $<12.5$ & $<12.5$ & $<250$ & $<125$ & $<125$ & $<125$ \\
\hline WS03 & $<12.5$ & $<500$ & $<12.5$ & $<12.5$ & $<12.5$ & $<250$ & $<125$ & $<125$ & $<125$ \\
\hline WS04(\#1) & $<12.5$ & $<500$ & $<12.5$ & $<12.5$ & $<12.5$ & $<250$ & $<125$ & $<125$ & $<125$ \\
\hline WS04(\#2) & $<12.5$ & $<500$ & $<12.5$ & $<12.5$ & $<12.5$ & $<250$ & $<125$ & $<125$ & $<125$ \\
\hline WS05 & $<12.5$ & $<500$ & $<12.5$ & $<12.5$ & $<12.5$ & $<250$ & $<125$ & $<125$ & $<125$ \\
\hline WS06(\#1) & $<12.5$ & $<500$ & $<12.5$ & $<12.5$ & $<12.5$ & $<250$ & $<125$ & $<125$ & $<125$ \\
\hline WS06(\#2) & $<12.5$ & $<500$ & $<12.5$ & $<12.5$ & $<12.5$ & $<250$ & $<125$ & $<125$ & $<125$ \\
\hline WS07(\#1) & $<12.5$ & $<500$ & $<12.5$ & $<12.5$ & $<12.5$ & $<250$ & $<125$ & $<125$ & $<125$ \\
\hline WS07(\#2) & $<12.5$ & $<500$ & $<12.5$ & $<12.5$ & $<12.5$ & $<250$ & $<125$ & $<125$ & $<125$ \\
\hline WS08(\#1) & $<12.5$ & $<500$ & $<12.5$ & $<12.5$ & $<12.5$ & $<250$ & $<125$ & $<125$ & $<125$ \\
\hline WS08(\#2) & $<12.5$ & $<500$ & $<12.5$ & $<12.5$ & $<12.5$ & $<250$ & $<125$ & $<125$ & $<125$ \\
\hline WS09 & $<12.5$ & $<500$ & $<12.5$ & $<12.5$ & $<12.5$ & $<250$ & $<125$ & $<125$ & $<125$ \\
\hline WS11 & $<12.5$ & $<500$ & $<12.5$ & $<12.5$ & $<12.5$ & $<250$ & $<125$ & $<125$ & $<125$ \\
\hline WS12(\#1) & $<12.5$ & $<500$ & $<12.5$ & $<12.5$ & $<12.5$ & $<250$ & $<125$ & $<125$ & $<125$ \\
\hline WS12(\#2) & $<12.5$ & $<500$ & $<12.5$ & $<12.5$ & $<12.5$ & $<250$ & $<125$ & $<125$ & $<125$ \\
\hline WS13 & $<12.5$ & $<500$ & $<12.5$ & $<12.5$ & $<12.5$ & $<250$ & $<125$ & $<125$ & $<125$ \\
\hline WS16 & $<12.5$ & $<500$ & $<12.5$ & $<12.5$ & $<12.5$ & $<250$ & $<125$ & $<125$ & $<125$ \\
\hline WS17(\#1) & $<12.5$ & $<500$ & $<12.5$ & $<12.5$ & $<12.5$ & $<250$ & $<125$ & $<125$ & $<125$ \\
\hline WS17(\#2) & $<12.5$ & $<500$ & $<12.5$ & $<12.5$ & $<12.5$ & $<250$ & $<125$ & $<125$ & $<125$ \\
\hline WS21(\#1) & $<12.5$ & $<500$ & $<12.5$ & $<12.5$ & $<12.5$ & $<250$ & $<125$ & $<125$ & $<125$ \\
\hline WS21(\#2) & $<12.5$ & $<500$ & $<12.5$ & $<12.5$ & $<12.5$ & $<250$ & $<125$ & $<125$ & $<125$ \\
\hline WS23 & $<12.5$ & $<500$ & $<12.5$ & $<12.5$ & $<12.5$ & $<250$ & $<125$ & $<125$ & $<125$ \\
\hline
\end{tabular}


Table 21. Concentrations of contaminants (ng/g wet weight) in plasma from white suckers (WS), common carp (CC), and largemouth bass (LMB) collected from the Charles River (August, 2005). Concentrations determined from electron ionization gas chromatography/mass spectrometry.

Analytes: 2-Methyl naphthalene to 4-Cumylphenol. (MQL, method quantitation limit; ng/g, nanogram per gram; <, values below the detection level; BHA, Butylated Hydroxyanisole)-Continued

\begin{tabular}{|c|c|c|c|c|c|c|c|c|c|}
\hline Sample & $\begin{array}{c}\text { 2-Methyl } \\
\text { naphthalene }\end{array}$ & $\begin{array}{c}\text { 3,4-Dichlorophenyl } \\
\text { isocyanate }\end{array}$ & $\begin{array}{c}\text { 1-Methyl } \\
\text { naphthalene }\end{array}$ & $\begin{array}{l}\text { 3-Methyl-1(H)- } \\
\text { indole (skatol) }\end{array}$ & $\begin{array}{l}\text { 2,6-Dimethyl } \\
\text { naphthalene }\end{array}$ & $\begin{array}{l}\text { 5-Methyl-1H- } \\
\text { benzotriazole }\end{array}$ & $\begin{array}{c}\text { 4-Tert- } \\
\text { octylphenol }\end{array}$ & $\begin{array}{c}\text { 4- } \\
\text { Octylphenol } \\
\end{array}$ & $\begin{array}{c}\text { 4- } \\
\text { Cumylphenol }\end{array}$ \\
\hline WS26 & $<12.5$ & $<500$ & $<12.5$ & $<12.5$ & $<12.5$ & $<250$ & $<125$ & $<125$ & $<125$ \\
\hline WS27(\#1) & $<12.5$ & $<500$ & $<12.5$ & $<12.5$ & $<12.5$ & $<250$ & $<125$ & $<125$ & $<125$ \\
\hline WS27(\#2) & $<12.5$ & $<500$ & $<12.5$ & $<12.5$ & $<12.5$ & $<250$ & $<125$ & $<125$ & $<125$ \\
\hline WS30(\#1) & $<12.5$ & $<500$ & $<12.5$ & $<12.5$ & $<12.5$ & $<250$ & $<125$ & $<125$ & $<125$ \\
\hline WS30(\#2) & $<12.5$ & $<500$ & $<12.5$ & $<12.5$ & $<12.5$ & $<250$ & $<125$ & $<125$ & $<125$ \\
\hline WS35 & $<12.5$ & $<500$ & $<12.5$ & $<12.5$ & $<12.5$ & $<250$ & $<125$ & $<125$ & $<125$ \\
\hline WS36 & $<12.5$ & $<500$ & $<12.5$ & $<12.5$ & $<12.5$ & $<250$ & $<125$ & $<125$ & $<125$ \\
\hline WS37 & $<12.5$ & $<500$ & $<12.5$ & $<12.5$ & $<12.5$ & $<250$ & $<125$ & $<125$ & $<125$ \\
\hline WS39 & $<12.5$ & $<500$ & $<12.5$ & $<12.5$ & $<12.5$ & $<250$ & $<125$ & $<125$ & $<125$ \\
\hline $\mathrm{CC} 01$ & $<12.5$ & $<500$ & $<12.5$ & $<12.5$ & $<12.5$ & $<250$ & $<125$ & $<125$ & $<125$ \\
\hline $\mathrm{CC} 02$ & $<12.5$ & $<500$ & $<12.5$ & $<12.5$ & $<12.5$ & $<250$ & $<125$ & $<125$ & $<125$ \\
\hline $\mathrm{CC} 04$ & $<12.5$ & $<500$ & $<12.5$ & $<12.5$ & $<12.5$ & $<250$ & $<125$ & $<125$ & $<125$ \\
\hline $\mathrm{CC} 05$ & $<12.5$ & $<500$ & $<12.5$ & $<12.5$ & $<12.5$ & $<250$ & $<125$ & $<125$ & $<125$ \\
\hline $\mathrm{CC} 07$ & $<12.5$ & $<500$ & $<12.5$ & $<12.5$ & $<12.5$ & $<250$ & $<125$ & $<125$ & $<125$ \\
\hline $\mathrm{CC} 09$ & $<12.5$ & $<500$ & $<12.5$ & $<12.5$ & $<12.5$ & $<250$ & $<125$ & $<125$ & $<125$ \\
\hline $\mathrm{CC} 10$ & $<12.5$ & $<500$ & $<12.5$ & $<12.5$ & $<12.5$ & $<250$ & $<125$ & $<125$ & $<125$ \\
\hline CC13 & $<12.5$ & $<500$ & $<12.5$ & $<12.5$ & $<12.5$ & $<250$ & $<125$ & $<125$ & $<125$ \\
\hline CC16 & $<12.5$ & $<500$ & $<12.5$ & $<12.5$ & $<12.5$ & $<250$ & $<125$ & $<125$ & $<125$ \\
\hline CC17 & $<12.5$ & $<500$ & $<12.5$ & $<12.5$ & $<12.5$ & $<250$ & $<125$ & $<125$ & $<125$ \\
\hline LMB01 & $<12.5$ & $<500$ & $<12.5$ & $<12.5$ & $<12.5$ & $<250$ & $<125$ & $<125$ & $<125$ \\
\hline LMB02 & $<12.5$ & $<500$ & $<12.5$ & $<12.5$ & $<12.5$ & $<250$ & $<125$ & $<125$ & $<125$ \\
\hline LMB05 & $<12.5$ & $<500$ & $<12.5$ & $<12.5$ & $<12.5$ & $<250$ & $<125$ & $<125$ & $<125$ \\
\hline LMB12 & $<12.5$ & $<500$ & $<12.5$ & $<12.5$ & $<12.5$ & $<250$ & $<125$ & $<125$ & $<125$ \\
\hline
\end{tabular}


Table 22. Concentrations (ng/g wet weight) of organochlorines, polybrominated diphenyl ether (PBDE), and polychlorinated biphenyls (PCBs) in plasma from white suckers (WS), common carp (CC), and largemouth bass (LMB) collected from the Charles River (August 2005). Concentrations determined from negative charge ionization $(\mathrm{NCl})$ gas chromatography/mass spectrometry. Values with a less than sign $(<)$ are below the method quantitation limit (MQL). Analytes: Aldrin to DCPA (Dacthal).

\begin{tabular}{|c|c|c|c|c|c|c|c|c|c|}
\hline Sample & Aldrin & Benfluralin & Chlorpyrifos & trans-chlordane & cis-chlordane & trans-nonachlor & $\begin{array}{c}\text { cis- } \\
\text { nonachlor }\end{array}$ & Oxychlordane & $\begin{array}{c}\text { DCPA } \\
\text { (dacthal) }\end{array}$ \\
\hline MQL & 10 & 5 & 10 & 10 & 5 & 5 & 5 & 25 & 5 \\
\hline Blank 1 & $<10$ & $<5$ & $<10$ & $<10$ & $<5$ & $<5$ & $<5$ & $<25$ & $<5$ \\
\hline Blank 2 & $<10$ & $<5$ & $<10$ & $<10$ & $<5$ & $<5$ & $<5$ & $<25$ & $<5$ \\
\hline Blank 3 & $<10$ & $<5$ & $<10$ & $<10$ & $<5$ & $<5$ & $<5$ & $<25$ & $<5$ \\
\hline Blank 4 & $<10$ & $<5$ & $<10$ & $<10$ & $<5$ & $<5$ & $<5$ & $<25$ & $<5$ \\
\hline Blank 5 & $<10$ & $<5$ & $<10$ & $<10$ & $<5$ & $<5$ & $<5$ & $<25$ & $<5$ \\
\hline WS02 & $<10$ & $<5$ & $<10$ & $<10$ & $<5$ & $<5$ & $<5$ & $<25$ & $<5$ \\
\hline WS03 & $<10$ & $<5$ & $<10$ & $<10$ & $<5$ & $<5$ & $<5$ & $<25$ & $<5$ \\
\hline WS04(\#1) & $<10$ & $<5$ & $<10$ & 19.3 & 24.1 & 20.2 & 16.7 & $<25$ & $<5$ \\
\hline WS04(\#2) & $<10$ & $<5$ & $<10$ & $<10$ & $<5$ & $<5$ & $<5$ & $<25$ & $<5$ \\
\hline WS05 & $<10$ & $<5$ & $<10$ & 21.4 & 27.6 & 22.0 & 17.6 & $<25$ & $<5$ \\
\hline WS06(\#1) & $<10$ & $<5$ & $<10$ & 19.7 & 25.0 & 19.5 & 16.6 & $<25$ & $<5$ \\
\hline WS06(\#2) & $<10$ & $<5$ & $<10$ & $<10$ & $<5$ & $<5$ & $<5$ & $<25$ & $<5$ \\
\hline WS07(\#1) & $<10$ & $<5$ & $<10$ & 22.6 & 31.0 & 23.8 & 18.1 & $<25$ & $<5$ \\
\hline WS07(\#2) & $<10$ & $<5$ & $<10$ & $<10$ & $<5$ & $<5$ & $<5$ & $<25$ & $<5$ \\
\hline WS08(\#1) & $<10$ & $<5$ & $<10$ & $<10$ & $<5$ & $<5$ & $<5$ & $<25$ & $<5$ \\
\hline WS08(\#2) & $<10$ & $<5$ & $<10$ & $<10$ & $<5$ & $<5$ & $<5$ & $<25$ & $<5$ \\
\hline WS09 & $<10$ & $<5$ & $<10$ & $<10$ & $<5$ & $<5$ & $<5$ & $<25$ & $<5$ \\
\hline WS11 & $<10$ & $<5$ & $<10$ & 18.2 & $<5$ & $<5$ & $<5$ & $<25$ & $<5$ \\
\hline WS12(\#1) & $<10$ & $<5$ & $<10$ & $<10$ & $<5$ & $<5$ & $<5$ & $<25$ & $<5$ \\
\hline WS12(\#2) & $<10$ & $<5$ & $<10$ & $<10$ & $<5$ & $<5$ & $<5$ & $<25$ & $<5$ \\
\hline WS13 & $<10$ & $<5$ & $<10$ & $<10$ & $<5$ & $<5$ & $<5$ & $<25$ & $<5$ \\
\hline WS16 & $<10$ & $<5$ & $<10$ & $<10$ & $<5$ & $<5$ & $<5$ & $<25$ & $<5$ \\
\hline WS17(\#1) & $<10$ & $<5$ & $<10$ & $<10$ & $<5$ & $<5$ & $<5$ & $<25$ & $<5$ \\
\hline WS17(\#2) & $<10$ & $<5$ & $<10$ & $<10$ & $<5$ & $<5$ & $<5$ & $<25$ & $<5$ \\
\hline WS21(\#1) & $<10$ & $<5$ & $<10$ & $<10$ & $<5$ & $<5$ & $<5$ & $<25$ & $<5$ \\
\hline WS21(\#2) & $<10$ & $<5$ & $<10$ & $<10$ & $<5$ & $<5$ & $<5$ & $<25$ & $<5$ \\
\hline WS23 & $<10$ & $<5$ & $<10$ & $<10$ & $<5$ & $<5$ & $<5$ & $<25$ & $<5$ \\
\hline
\end{tabular}


Table 22. Concentrations (ng/g wet weight) of organochlorines, polybrominated diphenyl ether (PBDE), and polychlorinated biphenyls (PCBs) in plasma from white suckers (WS), common carp (CC), and largemouth bass (LMB) collected from the Charles River (August 2005). Concentrations determined from negative charge ionization $(\mathrm{NCl})$ gas chromatography/mass spectrometry. Values with a less than sign $(<)$ are below the method quantitation limit (MQL). Analytes: Aldrin to DCPA (Dacthal). —Continued

\begin{tabular}{|c|c|c|c|c|c|c|c|c|c|}
\hline Sample & Aldrin & Benfluralin & Chlorpyrifos & trans-chlordane & cis-chlordane & trans-nonachlor & $\begin{array}{c}\text { cis- } \\
\text { nonachlor }\end{array}$ & Oxychlordane & $\begin{array}{c}\text { DCPA } \\
\text { (dacthal) }\end{array}$ \\
\hline WS26 & $<10$ & $<5$ & $<10$ & $<10$ & $<5$ & $<5$ & $<5$ & $<25$ & $<5$ \\
\hline WS27(\#1) & $<10$ & $<5$ & $<10$ & $<10$ & $<5$ & $<5$ & $<5$ & $<25$ & $<5$ \\
\hline WS27(\#2) & $<10$ & $<5$ & $<10$ & $<10$ & $<5$ & $<5$ & $<5$ & $<25$ & $<5$ \\
\hline WS30(\#1) & $<10$ & $<5$ & $<10$ & $<10$ & $<5$ & $<5$ & $<5$ & $<25$ & $<5$ \\
\hline WS30(\#2) & $<10$ & $<5$ & $<10$ & $<10$ & $<5$ & $<5$ & $<5$ & $<25$ & $<5$ \\
\hline WS35 & $<10$ & $<5$ & $<10$ & $<10$ & $<5$ & $<5$ & $<5$ & $<25$ & $<5$ \\
\hline WS36 & $<10$ & $<5$ & $<10$ & $<10$ & $<5$ & $<5$ & $<5$ & $<25$ & $<5$ \\
\hline WS37 & $<10$ & $<5$ & $<10$ & $<10$ & $<5$ & $<5$ & $<5$ & $<25$ & $<5$ \\
\hline WS39 & $<10$ & $<5$ & $<10$ & $<10$ & $<5$ & $<5$ & $<5$ & $<25$ & $<5$ \\
\hline $\mathrm{CC} 01$ & $<10$ & $<5$ & $<10$ & $<10$ & $<5$ & $<5$ & $<5$ & $<25$ & $<5$ \\
\hline $\mathrm{CC} 02$ & $<10$ & $<5$ & $<10$ & $<10$ & $<5$ & $<5$ & $<5$ & $<25$ & $<5$ \\
\hline $\mathrm{CC} 04$ & $<10$ & $<5$ & $<10$ & $<10$ & $<5$ & $<5$ & $<5$ & $<25$ & $<5$ \\
\hline $\mathrm{CC} 05$ & $<10$ & $<5$ & $<10$ & $<10$ & $<5$ & $<5$ & $<5$ & $<25$ & $<5$ \\
\hline $\mathrm{CC} 07$ & $<10$ & $<5$ & $<10$ & $<10$ & $<5$ & $<5$ & $<5$ & $<25$ & $<5$ \\
\hline $\mathrm{CC} 09$ & $<10$ & $<5$ & $<10$ & $<10$ & $<5$ & $<5$ & $<5$ & $<25$ & $<5$ \\
\hline $\mathrm{CC} 10$ & $<10$ & $<5$ & $<10$ & $<10$ & $<5$ & $<5$ & $<5$ & $<25$ & $<5$ \\
\hline $\mathrm{CC} 13$ & $<10$ & $<5$ & $<10$ & $<10$ & $<5$ & $<5$ & $<5$ & $<25$ & $<5$ \\
\hline $\mathrm{CC} 16$ & $<10$ & $<5$ & $<10$ & $<10$ & $<5$ & $<5$ & $<5$ & $<25$ & $<5$ \\
\hline CC17 & $<10$ & $<5$ & $<10$ & $<10$ & $<5$ & $<5$ & $<5$ & $<25$ & $<5$ \\
\hline LMB01 & $<10$ & $<5$ & $<10$ & $<10$ & $<5$ & 20.4 & 12.0 & $<25$ & $<5$ \\
\hline LMB02 & $<10$ & $<5$ & $<10$ & $<10$ & $<5$ & $<5$ & $<5$ & $<25$ & $<5$ \\
\hline LMB05 & $<10$ & $<5$ & $<10$ & $<10$ & $<5$ & $<5$ & $<5$ & $<25$ & $<5$ \\
\hline LMB12 & $<10$ & $<5$ & $<10$ & $<10$ & $<5$ & $<5$ & $<5$ & $<25$ & $<5$ \\
\hline
\end{tabular}


Table 22. Concentrations (ng/g, nanogram per gram wet weight) of organochlorines, polybrominated diphenyl ether (PBDE), and polychlorinated biphenyls (PCBs) in plasma from white suckers (WS), common carp (CC), and largemouth bass (LMB) collected from the Charles River (August, 2005). Concentrations determined from negative charge ionization $(\mathrm{NCl})$ gas chromatography/mass spectrometry. Analytes: $p, p^{\prime}-\mathrm{DDE}$ to endrin ketone. (MQL, method quantitation limit; ng/g, nanogram per gram; <, values below the detection level)—Continued

\begin{tabular}{|c|c|c|c|c|c|c|c|c|c|}
\hline Sample & $p, p '-D D E$ & $0, p '-D D E$ & $0, p^{\prime}-\mathrm{DDD}$ & $0, p^{\prime}=\mathrm{DDT}$ & $p, p$ 'DDT & Dieldrin & Endosulfan I & Endosulfan II & Endrin ketone \\
\hline MQL & 100 & 25 & 75 & 100 & 100 & 25 & 10 & 5 & 75 \\
\hline Blank 1 & $<100$ & $<25$ & $<75$ & $<100$ & $<100$ & $<25$ & $<10$ & $<5$ & $<75$ \\
\hline Blank 2 & $<100$ & $<25$ & $<75$ & $<100$ & $<100$ & $<25$ & $<10$ & $<5$ & $<75$ \\
\hline Blank 3 & $<100$ & $<25$ & $<75$ & $<100$ & $<100$ & $<25$ & $<10$ & $<5$ & $<75$ \\
\hline Blank 4 & $<100$ & $<25$ & $<75$ & $<100$ & $<100$ & $<25$ & $<10$ & $<5$ & $<75$ \\
\hline Blank 5 & $<100$ & $<25$ & $<75$ & $<100$ & $<100$ & $<25$ & $<10$ & $<5$ & $<75$ \\
\hline WS02 & $<100$ & $<25$ & $<75$ & $<100$ & $<100$ & $<25$ & $<10$ & $<5$ & $<75$ \\
\hline WS03 & $<100$ & $<25$ & $<75$ & $<100$ & $<100$ & $<25$ & $<10$ & $<5$ & $<75$ \\
\hline WS04(\#1) & $<100$ & $<25$ & $<75$ & $<100$ & $<100$ & $<25$ & $<10$ & $<5$ & $<75$ \\
\hline WS04(\#2) & $<100$ & $<25$ & $<75$ & $<100$ & $<100$ & $<25$ & $<10$ & $<5$ & $<75$ \\
\hline WS05 & $<100$ & $<25$ & $<75$ & $<100$ & $<100$ & $<25$ & $<10$ & $<5$ & $<75$ \\
\hline WS06(\#1) & $<100$ & $<25$ & $<75$ & $<100$ & $<100$ & $<25$ & $<10$ & $<5$ & $<75$ \\
\hline WS06(\#2) & $<100$ & $<25$ & $<75$ & $<100$ & $<100$ & $<25$ & $<10$ & $<5$ & $<75$ \\
\hline WS07(\#1) & $<100$ & $<25$ & $<75$ & $<100$ & $<100$ & $<25$ & $<10$ & $<5$ & $<75$ \\
\hline WS07(\#2) & $<100$ & $<25$ & $<75$ & $<100$ & $<100$ & $<25$ & $<10$ & $<5$ & $<75$ \\
\hline WS08(\#1) & $<100$ & $<25$ & $<75$ & $<100$ & $<100$ & $<25$ & $<10$ & $<5$ & $<75$ \\
\hline WS08(\#2) & $<100$ & $<25$ & $<75$ & $<100$ & $<100$ & $<25$ & $<10$ & $<5$ & $<75$ \\
\hline WS09 & $<100$ & $<25$ & $<75$ & $<100$ & $<100$ & $<25$ & $<10$ & $<5$ & $<75$ \\
\hline WS11 & $<100$ & $<25$ & $<75$ & $<100$ & $<100$ & $<25$ & $<10$ & $<5$ & $<75$ \\
\hline WS12(\#1) & $<100$ & $<25$ & $<75$ & $<100$ & $<100$ & $<25$ & $<10$ & $<5$ & $<75$ \\
\hline WS12(\#2) & $<100$ & $<25$ & $<75$ & $<100$ & $<100$ & $<25$ & $<10$ & $<5$ & $<75$ \\
\hline WS13 & $<100$ & $<25$ & $<75$ & $<100$ & $<100$ & $<25$ & $<10$ & $<5$ & $<75$ \\
\hline WS16 & $<100$ & $<25$ & $<75$ & $<100$ & $<100$ & $<25$ & $<10$ & $<5$ & $<75$ \\
\hline WS17(\#1) & $<100$ & $<25$ & $<75$ & $<100$ & $<100$ & $<25$ & $<10$ & $<5$ & $<75$ \\
\hline WS17(\#2) & $<100$ & $<25$ & $<75$ & $<100$ & $<100$ & $<25$ & $<10$ & $<5$ & $<75$ \\
\hline WS21(\#1) & $<100$ & $<25$ & $<75$ & $<100$ & $<100$ & $<25$ & $<10$ & $<5$ & $<75$ \\
\hline WS21(\#2) & $<100$ & $<25$ & $<75$ & $<100$ & $<100$ & $<25$ & $<10$ & $<5$ & $<75$ \\
\hline WS23 & $<100$ & $<25$ & $<75$ & $<100$ & $<100$ & $<25$ & $<10$ & $<5$ & $<75$ \\
\hline
\end{tabular}


Table 22. Concentrations (ng/g, nanogram per gram wet weight) of organochlorines, polybrominated diphenyl ether (PBDE), and polychlorinated biphenyls (PCBs) in plasma from white suckers (WS), common carp (CC), and largemouth bass (LMB) collected from the Charles River (August, 2005). Concentrations determined from negative charge ionization $(\mathrm{NCl})$ gas chromatography/mass spectrometry. Analytes: $p, p^{\prime}-\mathrm{DDE}$ to endrin ketone. (MQL, method quantitation limit; ng/g, nanogram per gram; <, values below the detection level)—Continued

\begin{tabular}{|c|c|c|c|c|c|c|c|c|c|}
\hline Sample & $p, p^{\prime}-D D E$ & o,p'-DDE & $0, p^{\prime}-D D D$ & o,p'-DDT & p,p'-DDT & Dieldrin & Endosulfan I & Endosulfan II & Endrin ketone \\
\hline WS26 & $<100$ & $<25$ & $<75$ & $<100$ & $<100$ & $<25$ & $<10$ & $<5$ & $<75$ \\
\hline WS27(\#1) & $<100$ & $<25$ & $<75$ & $<100$ & $<100$ & $<25$ & $<10$ & $<5$ & $<75$ \\
\hline WS27(\#2) & $<100$ & $<25$ & $<75$ & $<100$ & $<100$ & $<25$ & $<10$ & $<5$ & $<75$ \\
\hline WS30(\#1) & $<100$ & $<25$ & $<75$ & $<100$ & $<100$ & $<25$ & $<10$ & $<5$ & $<75$ \\
\hline WS30(\#2) & $<100$ & $<25$ & $<75$ & $<100$ & $<100$ & $<25$ & $<10$ & $<5$ & $<75$ \\
\hline WS35 & $<100$ & $<25$ & $<75$ & $<100$ & $<100$ & $<25$ & $<10$ & $<5$ & $<75$ \\
\hline WS36 & $<100$ & $<25$ & $<75$ & $<100$ & $<100$ & $<25$ & $<10$ & $<5$ & $<75$ \\
\hline WS37 & $<100$ & $<25$ & $<75$ & $<100$ & $<100$ & $<25$ & $<10$ & $<5$ & $<75$ \\
\hline WS39 & $<100$ & $<25$ & $<75$ & $<100$ & $<100$ & $<25$ & $<10$ & $<5$ & $<75$ \\
\hline $\mathrm{CC} 01$ & $<100$ & $<25$ & $<75$ & $<100$ & $<100$ & $<25$ & $<10$ & $<5$ & $<75$ \\
\hline $\mathrm{CC} 02$ & $<100$ & $<25$ & $<75$ & $<100$ & $<100$ & $<25$ & $<10$ & $<5$ & $<75$ \\
\hline $\mathrm{CC} 04$ & $<100$ & $<25$ & $<75$ & $<100$ & $<100$ & $<25$ & $<10$ & $<5$ & $<75$ \\
\hline $\mathrm{CC} 05$ & $<100$ & $<25$ & $<75$ & $<100$ & $<100$ & $<25$ & $<10$ & $<5$ & $<75$ \\
\hline $\mathrm{CC} 07$ & $<100$ & $<25$ & $<75$ & $<100$ & $<100$ & $<25$ & $<10$ & $<5$ & $<75$ \\
\hline CC09 & $<100$ & $<25$ & $<75$ & $<100$ & $<100$ & $<25$ & $<10$ & $<5$ & $<75$ \\
\hline CC10 & $<100$ & $<25$ & $<75$ & $<100$ & $<100$ & $<25$ & $<10$ & $<5$ & $<75$ \\
\hline CC13 & $<100$ & $<25$ & $<75$ & $<100$ & $<100$ & $<25$ & $<10$ & $<5$ & $<75$ \\
\hline CC16 & $<100$ & $<25$ & $<75$ & $<100$ & $<100$ & $<25$ & $<10$ & $<5$ & $<75$ \\
\hline CC17 & $<100$ & $<25$ & $<75$ & $<100$ & $<100$ & $<25$ & $<10$ & $<5$ & $<75$ \\
\hline LMB01 & $<100$ & $<25$ & $<75$ & $<100$ & $<100$ & $<25$ & $<10$ & $<5$ & $<75$ \\
\hline LMB02 & $<100$ & $<25$ & $<75$ & $<100$ & $<100$ & $<25$ & $<10$ & $<5$ & $<75$ \\
\hline LMB05 & $<100$ & $<25$ & $<75$ & $<100$ & $<100$ & $<25$ & $<10$ & $<5$ & $<75$ \\
\hline LMB12 & $<100$ & $<25$ & $<75$ & $<100$ & $<100$ & $<25$ & $<10$ & $<5$ & $<75$ \\
\hline
\end{tabular}


Table 22. Concentrations (ng/g, nanpgram per gram wet weight) of organochlorines, polybrominated diphenyl ether (PBDE), and polychlorinated biphenyls (PCBs) in plasma from white suckers (WS), common carp (CC), and largemouth bass (LMB) collected from the Charles River (August, 2005). Concentrations determined from negative charge ionization $(\mathrm{NCl})$ gas chromatography/mass spectrometry. Analytes: Fipronil to Octachlorostyrene. (MQL, method quantitation limit; ng/g, nanogram per gram; <, values below the detection level)—Continued

\begin{tabular}{|c|c|c|c|c|c|c|c|c|c|}
\hline Sample & Fipronil & $\alpha-\mathrm{HCH}$ & $\beta-\mathrm{HCH}$ & $\gamma-\mathrm{HCH}$ & $\delta-\mathrm{HCH}$ & $\begin{array}{c}\text { Heptachlor } \\
\text { epoxide }\end{array}$ & HCB & Mirex & Octachlorostyrene \\
\hline MQL & 25 & 10 & 50 & 25 & 25 & 25 & 5 & 10 & 5 \\
\hline Blank 1 & $<25$ & $<10$ & $<50$ & $<25$ & $<25$ & $<25$ & $<5$ & $<10$ & $<5$ \\
\hline Blank 2 & $<25$ & $<10$ & $<50$ & $<25$ & $<25$ & $<25$ & $<5$ & $<10$ & $<5$ \\
\hline Blank 3 & $<25$ & $<10$ & $<50$ & $<25$ & $<25$ & $<25$ & $<5$ & $<10$ & $<5$ \\
\hline Blank 4 & $<25$ & $<10$ & $<50$ & $<25$ & $<25$ & $<25$ & $<5$ & $<10$ & $<5$ \\
\hline Blank 5 & $<25$ & $<10$ & $<50$ & $<25$ & $<25$ & $<25$ & $<5$ & $<10$ & $<5$ \\
\hline WS02 & $<25$ & $<10$ & $<50$ & $<25$ & $<25$ & $<25$ & $<5$ & $<10$ & $<5$ \\
\hline WS03 & $<25$ & $<10$ & $<50$ & $<25$ & $<25$ & $<25$ & $<5$ & $<10$ & $<5$ \\
\hline WS04(\#1) & $<25$ & $<10$ & $<50$ & $<25$ & $<25$ & $<25$ & $<5$ & $<10$ & $<5$ \\
\hline WS04(\#2) & $<25$ & $<10$ & $<50$ & $<25$ & $<25$ & $<25$ & $<5$ & $<10$ & $<5$ \\
\hline WS05 & $<25$ & $<10$ & $<50$ & $<25$ & $<25$ & $<25$ & $<5$ & $<10$ & $<5$ \\
\hline WS06(\#1) & $<25$ & $<10$ & $<50$ & $<25$ & $<25$ & $<25$ & $<5$ & $<10$ & $<5$ \\
\hline WS06(\#2) & $<25$ & $<10$ & $<50$ & $<25$ & $<25$ & $<25$ & $<5$ & $<10$ & $<5$ \\
\hline WS07(\#1) & $<25$ & $<10$ & $<50$ & $<25$ & $<25$ & $<25$ & $<5$ & $<10$ & $<5$ \\
\hline WS07(\#2) & $<25$ & $<10$ & $<50$ & $<25$ & $<25$ & $<25$ & $<5$ & $<10$ & $<5$ \\
\hline WS08(\#1) & $<25$ & $<10$ & $<50$ & $<25$ & $<25$ & $<25$ & $<5$ & $<10$ & $<5$ \\
\hline WS08(\#2) & $<25$ & $<10$ & $<50$ & $<25$ & $<25$ & $<25$ & $<5$ & $<10$ & $<5$ \\
\hline WS09 & $<25$ & $<10$ & $<50$ & $<25$ & $<25$ & $<25$ & $<5$ & $<10$ & $<5$ \\
\hline WS11 & $<25$ & $<10$ & $<50$ & $<25$ & $<25$ & $<25$ & $<5$ & $<10$ & $<5$ \\
\hline WS12(\#1) & $<25$ & $<10$ & $<50$ & $<25$ & $<25$ & $<25$ & $<5$ & $<10$ & $<5$ \\
\hline WS12(\#2) & $<25$ & $<10$ & $<50$ & $<25$ & $<25$ & $<25$ & $<5$ & $<10$ & $<5$ \\
\hline WS13 & $<25$ & $<10$ & $<50$ & $<25$ & $<25$ & $<25$ & $<5$ & $<10$ & $<5$ \\
\hline WS16 & $<25$ & $<10$ & $<50$ & $<25$ & $<25$ & $<25$ & $<5$ & $<10$ & $<5$ \\
\hline WS17(\#1) & $<25$ & $<10$ & $<50$ & $<25$ & $<25$ & $<25$ & $<5$ & $<10$ & $<5$ \\
\hline WS17(\#2) & $<25$ & $<10$ & $<50$ & $<25$ & $<25$ & $<25$ & $<5$ & $<10$ & $<5$ \\
\hline WS21(\#1) & $<25$ & $<10$ & $<50$ & $<25$ & $<25$ & $<25$ & $<5$ & $<10$ & $<5$ \\
\hline WS21(\#2) & $<25$ & $<10$ & $<50$ & $<25$ & $<25$ & $<25$ & $<5$ & $<10$ & $<5$ \\
\hline WS23 & $<25$ & $<10$ & $<50$ & $<25$ & $<25$ & $<25$ & $<5$ & $<10$ & $<5$ \\
\hline
\end{tabular}


Table 22. Concentrations (ng/g, nanpgram per gram wet weight) of organochlorines, polybrominated diphenyl ether (PBDE), and polychlorinated biphenyls (PCBs) in plasma from white suckers (WS), common carp (CC), and largemouth bass (LMB) collected from the Charles River (August, 2005). Concentrations determined from negative charge ionization $(\mathrm{NCl})$ gas chromatography/mass spectrometry. Analytes: Fipronil to Octachlorostyrene. (MQL, method quantitation limit; ng/g, nanogram per gram; <, values below the detection level)—Continued

\begin{tabular}{|c|c|c|c|c|c|c|c|c|c|}
\hline Sample & Fipronil & $\alpha-\mathrm{HCH}$ & $\beta-\mathrm{HCH}$ & $\gamma-\mathrm{HCH}$ & $\delta-\mathrm{HCH}$ & $\begin{array}{c}\text { Heptachlor } \\
\text { epoxide }\end{array}$ & HCB & Mirex & Octachlorostyrene \\
\hline WS26 & $<25$ & $<10$ & $<50$ & $<25$ & $<25$ & $<25$ & $<5$ & $<10$ & $<5$ \\
\hline WS27(\#1) & $<25$ & $<10$ & $<50$ & $<25$ & $<25$ & $<25$ & $<5$ & $<10$ & $<5$ \\
\hline WS27(\#2) & $<25$ & $<10$ & $<50$ & $<25$ & $<25$ & $<25$ & $<5$ & $<10$ & $<5$ \\
\hline WS30(\#1) & $<25$ & $<10$ & $<50$ & $<25$ & $<25$ & $<25$ & $<5$ & $<10$ & $<5$ \\
\hline WS30(\#2) & $<25$ & $<10$ & $<50$ & $<25$ & $<25$ & $<25$ & $<5$ & $<10$ & $<5$ \\
\hline WS35 & $<25$ & $<10$ & $<50$ & $<25$ & $<25$ & $<25$ & $<5$ & $<10$ & $<5$ \\
\hline WS36 & $<25$ & $<10$ & $<50$ & $<25$ & $<25$ & $<25$ & $<5$ & $<10$ & $<5$ \\
\hline WS37 & $<25$ & $<10$ & $<50$ & $<25$ & $<25$ & $<25$ & 6.9 & $<10$ & 6.2 \\
\hline WS39 & $<25$ & $<10$ & $<50$ & $<25$ & $<25$ & $<25$ & $<5$ & $<10$ & $<5$ \\
\hline $\mathrm{CC} 01$ & $<25$ & $<10$ & $<50$ & $<25$ & $<25$ & $<25$ & $<5$ & $<10$ & $<5$ \\
\hline $\mathrm{CC} 02$ & $<25$ & $<10$ & $<50$ & $<25$ & $<25$ & $<25$ & $<5$ & $<10$ & $<5$ \\
\hline $\mathrm{CCO} 4$ & $<25$ & $<10$ & $<50$ & $<25$ & $<25$ & $<25$ & $<5$ & $<10$ & $<5$ \\
\hline $\mathrm{CC} 05$ & $<25$ & $<10$ & $<50$ & $<25$ & $<25$ & $<25$ & $<5$ & $<10$ & $<5$ \\
\hline $\mathrm{CC} 07$ & $<25$ & $<10$ & $<50$ & $<25$ & $<25$ & $<25$ & $<5$ & $<10$ & $<5$ \\
\hline $\mathrm{CC} 09$ & $<25$ & $<10$ & $<50$ & $<25$ & $<25$ & $<25$ & $<5$ & $<10$ & $<5$ \\
\hline $\mathrm{CC} 10$ & $<25$ & $<10$ & $<50$ & $<25$ & $<25$ & $<25$ & $<5$ & $<10$ & $<5$ \\
\hline $\mathrm{CC} 13$ & $<25$ & $<10$ & $<50$ & $<25$ & $<25$ & $<25$ & $<5$ & $<10$ & $<5$ \\
\hline $\mathrm{CC} 16$ & $<25$ & $<10$ & $<50$ & $<25$ & $<25$ & $<25$ & $<5$ & $<10$ & $<5$ \\
\hline CC17 & $<25$ & $<10$ & $<50$ & $<25$ & $<25$ & $<25$ & $<5$ & $<10$ & $<5$ \\
\hline LMB01 & $<25$ & $<10$ & $<50$ & $<25$ & $<25$ & $<25$ & $<5$ & $<10$ & $<5$ \\
\hline LMB02 & $<25$ & $<10$ & $<50$ & $<25$ & $<25$ & $<25$ & $<5$ & $<10$ & $<5$ \\
\hline LMB05 & $<25$ & $<10$ & $<50$ & $<25$ & $<25$ & $<25$ & $<5$ & $<10$ & $<5$ \\
\hline LMB12 & $<25$ & $<10$ & $<50$ & $<25$ & $<25$ & $<25$ & $<5$ & $<10$ & $<5$ \\
\hline
\end{tabular}


Table 22. Concentrations (ng/g, nanogram per gram wet weight) of organochlorines, polybrominated diphenyl ether (PBDE), and polychlorinated biphenyls (PCBs) in plasma from white suckers (WS), common carp (CC), and largemouth bass (LMB) collected from the Charles River (August, 2005). Concentrations determined from negative charge ionization ( $\mathrm{NCl}$ ) gas chromatography/mass spectrometry. Analytes: PCA to PBDE 183. (MQL, method quantitation limit; ng/g, nanogram per gram; <, values below the detection level)—Continued

\begin{tabular}{|c|c|c|c|c|c|c|c|c|c|c|c|c|}
\hline Sample & PCA & Trifluralin & $\begin{array}{c}\text { PBDE } \\
47\end{array}$ & PBDE 66 & PBDE 71 & PBDE 85 & PBDE 99 & $\begin{array}{c}\text { PBDE } \\
100\end{array}$ & $\begin{array}{c}\text { PBDE } \\
138\end{array}$ & $\begin{array}{c}\text { PBDE } \\
153\end{array}$ & $\begin{array}{c}\text { PBDE } \\
154\end{array}$ & $\begin{array}{c}\text { PBDE } \\
183\end{array}$ \\
\hline MQL & 5 & 5 & 5 & 5 & 5 & 5 & 5 & 5 & 5 & 5 & 5 & 5 \\
\hline Blank 1 & $<5$ & $<5$ & $<5$ & $<5$ & $<5$ & $<5$ & $<5$ & $<5$ & $<5$ & $<5$ & $<5$ & $<5$ \\
\hline Blank 2 & $<5$ & $<5$ & $<5$ & $<5$ & $<5$ & $<5$ & $<5$ & $<5$ & $<5$ & $<5$ & $<5$ & $<5$ \\
\hline Blank 3 & $<5$ & $<5$ & $<5$ & $<5$ & $<5$ & $<5$ & $<5$ & $<5$ & $<5$ & $<5$ & $<5$ & $<5$ \\
\hline Blank 4 & $<5$ & $<5$ & $<5$ & $<5$ & $<5$ & $<5$ & $<5$ & $<5$ & $<5$ & $<5$ & $<5$ & $<5$ \\
\hline Blank 5 & $<5$ & $<5$ & $<5$ & $<5$ & $<5$ & $<5$ & $<5$ & $<5$ & $<5$ & $<5$ & $<5$ & $<5$ \\
\hline WS02 & $<5$ & $<5$ & $<5$ & $<5$ & $<5$ & $<5$ & $<5$ & $<5$ & $<5$ & $<5$ & $<5$ & $<5$ \\
\hline WS03 & $<5$ & $<5$ & 14.5 & $<5$ & $<5$ & $<5$ & $<5$ & $<5$ & $<5$ & $<5$ & $<5$ & $<5$ \\
\hline WS04(\#1) & $<5$ & $<5$ & 9.3 & $<5$ & $<5$ & $<5$ & 6.7 & 5.5 & $<5$ & $<5$ & $<5$ & $<5$ \\
\hline WS04(\#2) & $<5$ & $<5$ & 10.3 & $<5$ & $<5$ & $<5$ & $<5$ & $<5$ & $<5$ & $<5$ & $<5$ & $<5$ \\
\hline WS05 & $<5$ & $<5$ & 17.5 & $<5$ & 20.4 & $<5$ & 7.0 & 6.5 & $<5$ & $<5$ & $<5$ & $<5$ \\
\hline WS06(\#1) & $<5$ & $<5$ & 17.6 & 18.3 & 19.8 & $<5$ & 6.6 & 6.2 & $<5$ & $<5$ & $<5$ & $<5$ \\
\hline WS06(\#2) & $<5$ & $<5$ & $<5$ & $<5$ & $<5$ & $<5$ & $<5$ & $<5$ & $<5$ & $<5$ & $<5$ & $<5$ \\
\hline WS07(\#1) & $<5$ & $<5$ & 25.0 & 19.7 & 24.4 & $<5$ & 7.2 & $<5$ & $<5$ & $<5$ & $<5$ & $<5$ \\
\hline WS07(\#2) & $<5$ & $<5$ & $<5$ & $<5$ & $<5$ & $<5$ & $<5$ & $<5$ & $<5$ & $<5$ & $<5$ & $<5$ \\
\hline WS08(\#1) & $<5$ & $<5$ & 7.7 & $<5$ & $<5$ & $<5$ & $<5$ & $<5$ & $<5$ & $<5$ & $<5$ & $<5$ \\
\hline WS08(\#2) & $<5$ & $<5$ & $<5$ & $<5$ & $<5$ & $<5$ & $<5$ & $<5$ & $<5$ & $<5$ & $<5$ & $<5$ \\
\hline WS09 & $<5$ & $<5$ & $<5$ & $<5$ & $<5$ & $<5$ & $<5$ & $<5$ & $<5$ & $<5$ & $<5$ & $<5$ \\
\hline WS11 & $<5$ & $<5$ & 5.0 & $<5$ & $<5$ & $<5$ & $<5$ & $<5$ & $<5$ & $<5$ & $<5$ & $<5$ \\
\hline WS12(\#1) & $<5$ & $<5$ & $<5$ & $<5$ & $<5$ & $<5$ & $<5$ & $<5$ & $<5$ & $<5$ & $<5$ & $<5$ \\
\hline WS12(\#2) & $<5$ & $<5$ & $<5$ & $<5$ & $<5$ & $<5$ & $<5$ & $<5$ & $<5$ & $<5$ & $<5$ & $<5$ \\
\hline WS13 & $<5$ & $<5$ & $<5$ & $<5$ & $<5$ & $<5$ & $<5$ & $<5$ & $<5$ & $<5$ & $<5$ & $<5$ \\
\hline WS16 & $<5$ & $<5$ & $<5$ & $<5$ & $<5$ & $<5$ & $<5$ & $<5$ & $<5$ & $<5$ & $<5$ & $<5$ \\
\hline WS17(\#1) & $<5$ & $<5$ & 5.9 & $<5$ & $<5$ & $<5$ & $<5$ & $<5$ & $<5$ & $<5$ & $<5$ & $<5$ \\
\hline WS17(\#2) & $<5$ & $<5$ & $<5$ & $<5$ & $<5$ & $<5$ & $<5$ & $<5$ & $<5$ & $<5$ & $<5$ & $<5$ \\
\hline WS21(\#1) & $<5$ & $<5$ & $<5$ & $<5$ & $<5$ & $<5$ & $<5$ & $<5$ & $<5$ & $<5$ & $<5$ & $<5$ \\
\hline WS21(\#2) & $<5$ & $<5$ & $<5$ & $<5$ & $<5$ & $<5$ & $<5$ & $<5$ & $<5$ & $<5$ & $<5$ & $<5$ \\
\hline WS23 & $<5$ & $<5$ & 13.1 & $<5$ & $<5$ & $<5$ & $<5$ & $<5$ & $<5$ & $<5$ & $<5$ & $<5$ \\
\hline
\end{tabular}


Table 22. Concentrations (ng/g, nanogram per gram wet weight) of organochlorines, polybrominated diphenyl ether (PBDE), and polychlorinated biphenyls (PCBs) in plasma from white suckers (WS), common carp (CC), and largemouth bass (LMB) collected from the Charles River (August, 2005). Concentrations determined from negative charge ionization ( $\mathrm{NCl}$ ) gas chromatography/mass spectrometry. Analytes: PCA to PBDE 183. (MQL, method quantitation limit; ng/g, nanogram per gram; <, values below the detection level)—Continued

\begin{tabular}{|c|c|c|c|c|c|c|c|c|c|c|c|c|}
\hline Sample & PCA & Trifluralin & $\begin{array}{c}\text { PBDE } \\
47\end{array}$ & PBDE 66 & PBDE 71 & PBDE 85 & PBDE 99 & $\begin{array}{c}\text { PBDE } \\
100 \\
\end{array}$ & $\begin{array}{c}\text { PBDE } \\
138 \\
\end{array}$ & $\begin{array}{c}\text { PBDE } \\
153 \\
\end{array}$ & $\begin{array}{c}\text { PBDE } \\
154 \\
\end{array}$ & $\begin{array}{c}\text { PBDE } \\
183 \\
\end{array}$ \\
\hline WS26 & $<5$ & $<5$ & $<5$ & $<5$ & $<5$ & $<5$ & $<5$ & $<5$ & $<5$ & $<5$ & $<5$ & $<5$ \\
\hline WS27(\#1) & $<5$ & $<5$ & $<5$ & $<5$ & $<5$ & $<5$ & $<5$ & $<5$ & $<5$ & $<5$ & $<5$ & $<5$ \\
\hline WS27(\#2) & $<5$ & $<5$ & $<5$ & $<5$ & $<5$ & $<5$ & $<5$ & $<5$ & $<5$ & $<5$ & $<5$ & $<5$ \\
\hline WS30(\#1) & $<5$ & $<5$ & 4.9 & $<5$ & $<5$ & $<5$ & $<5$ & $<5$ & $<5$ & $<5$ & $<5$ & $<5$ \\
\hline WS30(\#2) & $<5$ & $<5$ & $<5$ & $<5$ & $<5$ & $<5$ & $<5$ & $<5$ & $<5$ & $<5$ & $<5$ & $<5$ \\
\hline WS35 & $<5$ & $<5$ & $<5$ & $<5$ & $<5$ & $<5$ & $<5$ & $<5$ & $<5$ & $<5$ & $<5$ & $<5$ \\
\hline WS36 & $<5$ & $<5$ & 11.6 & $<5$ & $<5$ & $<5$ & $<5$ & $<5$ & $<5$ & $<5$ & $<5$ & $<5$ \\
\hline WS37 & $<5$ & $<5$ & $<5$ & $<5$ & $<5$ & $<5$ & $<5$ & $<5$ & $<5$ & $<5$ & $<5$ & $<5$ \\
\hline WS39 & $<5$ & $<5$ & $<5$ & $<5$ & $<5$ & $<5$ & $<5$ & $<5$ & $<5$ & $<5$ & $<5$ & $<5$ \\
\hline $\mathrm{CC} 01$ & $<5$ & $<5$ & $<5$ & $<5$ & $<5$ & $<5$ & $<5$ & $<5$ & $<5$ & $<5$ & $<5$ & $<5$ \\
\hline $\mathrm{CC} 02$ & $<5$ & $<5$ & $<5$ & $<5$ & $<5$ & $<5$ & $<5$ & $<5$ & $<5$ & $<5$ & $<5$ & $<5$ \\
\hline $\mathrm{CC} 04$ & $<5$ & $<5$ & 7.7 & $<5$ & $<5$ & $<5$ & $<5$ & $<5$ & $<5$ & $<5$ & $<5$ & $<5$ \\
\hline $\mathrm{CC} 05$ & $<5$ & $<5$ & $<5$ & $<5$ & $<5$ & $<5$ & $<5$ & $<5$ & $<5$ & $<5$ & $<5$ & $<5$ \\
\hline $\mathrm{CC} 07$ & $<5$ & $<5$ & $<5$ & $<5$ & $<5$ & $<5$ & $<5$ & $<5$ & $<5$ & $<5$ & $<5$ & $<5$ \\
\hline $\mathrm{CC} 09$ & $<5$ & $<5$ & $<5$ & $<5$ & $<5$ & $<5$ & $<5$ & $<5$ & $<5$ & $<5$ & $<5$ & $<5$ \\
\hline $\mathrm{CC} 10$ & $<5$ & $<5$ & $<5$ & $<5$ & $<5$ & $<5$ & $<5$ & $<5$ & $<5$ & $<5$ & $<5$ & $<5$ \\
\hline $\mathrm{CC} 13$ & $<5$ & $<5$ & $<5$ & $<5$ & $<5$ & $<5$ & $<5$ & $<5$ & $<5$ & $<5$ & $<5$ & $<5$ \\
\hline $\mathrm{CC} 16$ & $<5$ & $<5$ & $<5$ & $<5$ & $<5$ & $<5$ & $<5$ & $<5$ & $<5$ & $<5$ & $<5$ & $<5$ \\
\hline $\mathrm{CC} 17$ & $<5$ & $<5$ & $<5$ & $<5$ & $<5$ & $<5$ & $<5$ & $<5$ & $<5$ & $<5$ & $<5$ & $<5$ \\
\hline LMB01 & $<5$ & $<5$ & 16.9 & $<5$ & $<5$ & $<5$ & $<5$ & $<5$ & $<5$ & $<5$ & $<5$ & $<5$ \\
\hline LMB02 & $<5$ & $<5$ & $<5$ & $<5$ & $<5$ & $<5$ & $<5$ & $<5$ & $<5$ & $<5$ & $<5$ & $<5$ \\
\hline LMB05 & $<5$ & $<5$ & $<5$ & $<5$ & $<5$ & $<5$ & $<5$ & $<5$ & $<5$ & $<5$ & $<5$ & $<5$ \\
\hline LMB12 & $<5$ & $<5$ & $<5$ & $<5$ & $<5$ & $<5$ & $<5$ & $<5$ & $<5$ & $<5$ & $<5$ & $<5$ \\
\hline
\end{tabular}


Table 22. Concentrations (ng/g, nanogram per gram wet weight) of organochlorines, polybrominated diphenyl ether (PBDE), and polychlorinated biphenyls (PCBs) in plasma from white suckers (WS), common carp (CC), and largemouth bass (LMB) collected from the Charles River (August, 2005). Concentrations determined from negative charge ionization (NCl) gas chromatography/mass spectrometry. Analytes: PCB 70 to PCB 180. (MQL, method quantitation limit; $\mathrm{ng} / \mathrm{g}$, nanogram per gram; <, values below the detection level)—Continued

\begin{tabular}{|c|c|c|c|c|c|c|c|c|c|c|c|c|}
\hline Sample & PCB 70 & PCB 101 & PCB 110 & PCB 118 & PCB 138 & PCB 146 & РCB 149 & PCB 151 & PCB 170 & PCB 174 & PCB 177 & PCB 180 \\
\hline MQL & 100 & 75 & 75 & 5 & 5 & 5 & 25 & 10 & 5 & 5 & 5 & 5 \\
\hline Blank 1 & $<100$ & $<75$ & $<75$ & $<5$ & $<5$ & $<5$ & $<25$ & $<10$ & $<5$ & $<5$ & $<5$ & $<5$ \\
\hline Blank 2 & $<100$ & $<75$ & $<75$ & $<5$ & $<5$ & $<5$ & $<25$ & $<10$ & $<5$ & $<5$ & $<5$ & $<5$ \\
\hline Blank 3 & $<100$ & $<75$ & $<75$ & $<5$ & $<5$ & $<5$ & $<25$ & $<10$ & $<5$ & $<5$ & $<5$ & $<5$ \\
\hline Blank 4 & $<100$ & $<75$ & $<75$ & $<5$ & $<5$ & $<5$ & $<25$ & $<10$ & $<5$ & $<5$ & $<5$ & $<5$ \\
\hline Blank 5 & $<100$ & $<75$ & $<75$ & $<5$ & $<5$ & $<5$ & $<25$ & $<10$ & $<5$ & $<5$ & $<5$ & $<5$ \\
\hline WS02 & $<100$ & $<75$ & $<75$ & 13.5 & 24.2 & $<5$ & $<25$ & $<10$ & 6.84 & $<5$ & $<5$ & 9.79 \\
\hline WS03 & $<100$ & $<75$ & $<75$ & 13.7 & 20.5 & $<5$ & $<25$ & $<10$ & $<5$ & $<5$ & $<5$ & 8.33 \\
\hline WS04(\#1) & $<100$ & $<75$ & $<75$ & 24 & 39.5 & 13 & $<25$ & $<10$ & 13.8 & 14.9 & $<5$ & 13.9 \\
\hline WS04(\#2) & $<100$ & $<75$ & $<75$ & 17.9 & 31.6 & $<5$ & $<25$ & $<10$ & 7.82 & $<5$ & $<5$ & 11.2 \\
\hline WS05 & $<100$ & $<75$ & $<75$ & 31.6 & 63.6 & 14.7 & $<25$ & $<10$ & 16.3 & 17.9 & 12.2 & 17.4 \\
\hline WS06(\#1) & $<100$ & $<75$ & $<75$ & 28.8 & 47.2 & 13.5 & $<25$ & $<10$ & 14.4 & 15.5 & $<5$ & 14.1 \\
\hline WS06(\#2) & $<100$ & $<75$ & $<75$ & 12.9 & 21.3 & $<5$ & $<25$ & $<10$ & $<5$ & $<5$ & $<5$ & 8.54 \\
\hline WS07(\#1) & $<100$ & $<75$ & $<75$ & 37 & 73.2 & 15.6 & $<25$ & $<10$ & 16.9 & 19.2 & 12.7 & 20.4 \\
\hline WS07(\#2) & $<100$ & $<75$ & $<75$ & $<5$ & $<5$ & $<5$ & $<25$ & $<10$ & $<5$ & $<5$ & $<5$ & $<5$ \\
\hline WS08(\#1) & $<100$ & $<75$ & $<75$ & 25.6 & 44.4 & 13.6 & $<25$ & $<10$ & 14.3 & 15.5 & 11.1 & 13.7 \\
\hline WS08(\#2) & $<100$ & $<75$ & $<75$ & $<5$ & $<5$ & $<5$ & $<25$ & $<10$ & $<5$ & $<5$ & $<5$ & $<5$ \\
\hline WS09 & $<100$ & $<75$ & $<75$ & $<5$ & 26.6 & $<5$ & $<25$ & $<10$ & 11.9 & 12.9 & $<5$ & 9.4 \\
\hline WS11 & $<100$ & $<75$ & $<75$ & 23.5 & 37.7 & $<5$ & $<25$ & $<10$ & 13.2 & 14.7 & 11 & 12.6 \\
\hline WS12(\#1) & $<100$ & $<75$ & $<75$ & $<5$ & $<5$ & $<5$ & $<25$ & $<10$ & $<5$ & $<5$ & $<5$ & $<5$ \\
\hline WS12(\#2) & $<100$ & $<75$ & $<75$ & $<5$ & $<5$ & $<5$ & $<25$ & $<10$ & $<5$ & $<5$ & $<5$ & 5.38 \\
\hline WS13 & $<100$ & $<75$ & $<75$ & $<5$ & $<5$ & $<5$ & $<25$ & $<10$ & $<5$ & $<5$ & $<5$ & 8.2 \\
\hline WS16 & $<100$ & $<75$ & $<75$ & $<5$ & 32.9 & 12.7 & $<25$ & $<10$ & 13.4 & 14.7 & 10.8 & 12.5 \\
\hline WS17(\#1) & $<100$ & $<75$ & $<75$ & 22 & 32.4 & $<5$ & $<25$ & $<10$ & 12.5 & 13.8 & $<5$ & 10.4 \\
\hline WS17(\#2) & $<100$ & $<75$ & $<75$ & $<5$ & $<5$ & $<5$ & $<25$ & $<10$ & $<5$ & $<5$ & $<5$ & $<5$ \\
\hline WS21(\#1) & $<100$ & $<75$ & $<75$ & $<5$ & $<5$ & $<5$ & $<25$ & $<10$ & $<5$ & $<5$ & $<5$ & $<5$ \\
\hline WS21(\#2) & $<100$ & $<75$ & $<75$ & $<5$ & $<5$ & $<5$ & $<25$ & $<10$ & $<5$ & $<5$ & $<5$ & $<5$ \\
\hline WS23 & $<100$ & $<75$ & $<75$ & $<5$ & 33.6 & $<5$ & $<25$ & $<10$ & 12.7 & 14.2 & $<5$ & 11.4 \\
\hline WS26 & $<100$ & $<75$ & $<75$ & $<5$ & $<5$ & $<5$ & $<25$ & $<10$ & $<5$ & $<5$ & $<5$ & 8.88 \\
\hline WS27(\#1) & $<100$ & $<75$ & $<75$ & $<5$ & 28.9 & $<5$ & $<25$ & $<10$ & $<5$ & $<5$ & $<5$ & 9.24 \\
\hline
\end{tabular}


Table 22. Concentrations (ng/g, nanogram per gram wet weight) of organochlorines, polybrominated diphenyl ether (PBDE), and polychlorinated biphenyls (PCBs) in plasma from white suckers (WS), common carp (CC), and largemouth bass (LMB) collected from the Charles River (August, 2005). Concentrations determined from negative charge ionization (NCl) gas chromatography/mass spectrometry. Analytes: PCB 70 to PCB 180. (MQL, method quantitation limit; $\mathrm{ng} / \mathrm{g}$, nanogram per gram; <, values below the detection level)—Continued

\begin{tabular}{|c|c|c|c|c|c|c|c|c|c|c|c|c|}
\hline Sample & PCB 70 & РCB 101 & PCB 110 & PCB 118 & PCB 138 & PCB 146 & РCB 149 & РCB 151 & РCB 170 & PCB 174 & PCB 177 & PCB 180 \\
\hline WS27(\#2) & $<100$ & $<75$ & $<75$ & $<5$ & 16.3 & $<5$ & $<25$ & $<10$ & 5.61 & $<5$ & $<5$ & 6.67 \\
\hline WS30(\#1) & $<100$ & $<75$ & $<75$ & $<5$ & $<5$ & $<5$ & $<25$ & $<10$ & $<5$ & $<5$ & $<5$ & $<5$ \\
\hline WS30(\#2) & $<100$ & $<75$ & $<75$ & $<5$ & $<5$ & $<5$ & $<25$ & $<10$ & $<5$ & $<5$ & $<5$ & 5.93 \\
\hline WS35 & $<100$ & $<75$ & $<75$ & 10.3 & 16.9 & $<5$ & $<25$ & $<10$ & 5.73 & $<5$ & $<5$ & 7.21 \\
\hline WS36 & $<100$ & $<75$ & $<75$ & $<5$ & $<5$ & $<5$ & $<25$ & $<10$ & $<5$ & $<5$ & $<5$ & $<5$ \\
\hline WS37 & $<100$ & $<75$ & $<75$ & 7.1 & 13.2 & $<5$ & $<25$ & $<10$ & $<5$ & $<5$ & $<5$ & $<5$ \\
\hline WS39 & $<100$ & $<75$ & $<75$ & $<5$ & $<5$ & $<5$ & $<25$ & $<10$ & 12.7 & $<5$ & $<5$ & 11.2 \\
\hline $\mathrm{CC} 01$ & $<100$ & $<75$ & $<75$ & 25.7 & 50.8 & $<5$ & $<25$ & $<10$ & 11.4 & $<5$ & $<5$ & 18.2 \\
\hline $\mathrm{CC} 02$ & $<100$ & $<75$ & $<75$ & $<5$ & 18.4 & $<5$ & $<25$ & $<10$ & $<5$ & $<5$ & $<5$ & 7.72 \\
\hline $\mathrm{CC} 04$ & $<100$ & $<75$ & $<75$ & 15.6 & 32.7 & $<5$ & $<25$ & $<10$ & 8.98 & $<5$ & $<5$ & 14.4 \\
\hline $\mathrm{CC} 05$ & $<100$ & $<75$ & $<75$ & $<5$ & $<5$ & $<5$ & $<25$ & $<10$ & $<5$ & $<5$ & $<5$ & $<5$ \\
\hline $\mathrm{CC} 07$ & $<100$ & $<75$ & $<75$ & $<5$ & $<5$ & $<5$ & $<25$ & $<10$ & $<5$ & $<5$ & $<5$ & 6.18 \\
\hline $\mathrm{CC} 09$ & $<100$ & $<75$ & $<75$ & $<5$ & $<5$ & $<5$ & $<25$ & $<10$ & $<5$ & $<5$ & $<5$ & $<5$ \\
\hline CC10 & $<100$ & $<75$ & $<75$ & $<5$ & $<5$ & $<5$ & $<25$ & $<10$ & $<5$ & $<5$ & $<5$ & $<5$ \\
\hline CC13 & $<100$ & $<75$ & $<75$ & $<5$ & $<5$ & $<5$ & $<25$ & $<10$ & $<5$ & $<5$ & $<5$ & 5.01 \\
\hline $\mathrm{CC} 16$ & $<100$ & $<75$ & $<75$ & $<5$ & $<5$ & $<5$ & $<25$ & $<10$ & $<5$ & $<5$ & $<5$ & $<5$ \\
\hline CC17 & $<100$ & $<75$ & $<75$ & $<5$ & $<5$ & $<5$ & $<25$ & $<10$ & $<5$ & $<5$ & $<5$ & $<5$ \\
\hline LMB01 & $<100$ & $<75$ & $<75$ & 31.9 & 57.2 & 8.91 & $<25$ & $<10$ & 12.8 & 8.86 & $<5$ & 25.6 \\
\hline LMB02 & $<100$ & $<75$ & $<75$ & 10.6 & 15 & $<5$ & $<25$ & $<10$ & 5.39 & $<5$ & $<5$ & 6.66 \\
\hline LMB05 & $<100$ & $<75$ & $<75$ & 47 & 78.4 & 12.1 & $<25$ & $<10$ & 14.2 & 11.1 & $<5$ & 27.9 \\
\hline LMB12 & $<100$ & $<75$ & $<75$ & 13.9 & 20.5 & $<5$ & $<25$ & $<10$ & 5.83 & $<5$ & $<5$ & 10.8 \\
\hline
\end{tabular}


Table 22. Concentrations (ng/g, nanogram per gram wet weight) of organochlorines, polybrominated diphenyl ether (PBDE), and polychlorinated biphenyls (PCBs) in plasma from white suckers (WS), common carp (CC), and largemouth bass (LMB) collected from the Charles River (August, 2005). Concentrations determined from negative charge ionization ( $\mathrm{NCl}$ ) gas chromatography/mass spectrometry. Analytes: PCB 183 to PCB 206. (MQL, method quantitation limit; $\mathrm{ng} / \mathrm{g}$, nanogram per gram; <, values below the detection level)—Continued

\begin{tabular}{|c|c|c|c|c|}
\hline Sample & PCB 183 & PCB 187 & PCB 194 & PCB 206 \\
\hline MQL & 5 & 5 & 5 & 5 \\
\hline Blank 1 & $<5$ & $<5$ & $<5$ & $<5$ \\
\hline Blank 2 & $<5$ & $<5$ & $<5$ & $<5$ \\
\hline Blank 3 & $<5$ & $<5$ & $<5$ & $<5$ \\
\hline Blank 4 & $<5$ & $<5$ & $<5$ & $<5$ \\
\hline Blank 5 & $<5$ & $<5$ & $<5$ & $<5$ \\
\hline WS02 & $<5$ & 6.2 & $<5$ & $<5$ \\
\hline WS03 & $<5$ & 5.51 & $<5$ & $<5$ \\
\hline WS04(\#1) & $<5$ & $<5$ & $<5$ & $<5$ \\
\hline WS04(\#2) & $<5$ & 7.56 & $<5$ & $<5$ \\
\hline WS05 & $<5$ & $<5$ & $<5$ & $<5$ \\
\hline WS06(\#1) & $<5$ & $<5$ & $<5$ & $<5$ \\
\hline WS06(\#2) & $<5$ & 5.4 & $<5$ & $<5$ \\
\hline WS07(\#1) & 16.2 & 16.3 & $<5$ & $<5$ \\
\hline WS07(\#2) & $<5$ & $<5$ & $<5$ & $<5$ \\
\hline WS08(\#1) & $<5$ & $<5$ & $<5$ & $<5$ \\
\hline WS08(\#2) & $<5$ & $<5$ & $<5$ & $<5$ \\
\hline WS09 & $<5$ & $<5$ & $<5$ & $<5$ \\
\hline WS11 & $<5$ & $<5$ & $<5$ & $<5$ \\
\hline WS12(\#1) & $<5$ & $<5$ & $<5$ & $<5$ \\
\hline WS12(\#2) & $<5$ & $<5$ & $<5$ & $<5$ \\
\hline WS13 & $<5$ & $<5$ & $<5$ & $<5$ \\
\hline WS16 & $<5$ & $<5$ & $<5$ & $<5$ \\
\hline WS17(\#1) & $<5$ & $<5$ & $<5$ & $<5$ \\
\hline WS17(\#2) & $<5$ & $<5$ & $<5$ & $<5$ \\
\hline WS21(\#1) & $<5$ & $<5$ & $<5$ & $<5$ \\
\hline WS21(\#2) & $<5$ & $<5$ & $<5$ & $<5$ \\
\hline WS23 & $<5$ & $<5$ & $<5$ & $<5$ \\
\hline WS26 & $<5$ & $<5$ & $<5$ & $<5$ \\
\hline WS27(\#1) & $<5$ & $<5$ & $<5$ & $<5$ \\
\hline
\end{tabular}


Table 22. Concentrations (ng/g, nanogram per gram wet weight) of organochlorines, polybrominated diphenyl ether (PBDE), and polychlorinated biphenyls (PCBs) in plasma from white suckers (WS), common carp (CC), and largemouth bass (LMB) collected from the Charles River (August, 2005). Concentrations determined from negative charge ionization ( $\mathrm{NCl}$ ) gas chromatography/mass spectrometry. Analytes: PCB 183 to PCB 206. (MQL, method quantitation limit; $\mathrm{ng} / \mathrm{g}$, nanogram per gram; <, values below the detection level)—Continued

\begin{tabular}{lcccc}
\hline Sample & PCB 183 & PCB 187 & PCB 194 & PCB 206 \\
\hline WS27(\#2) & $<5$ & $<5$ & $<5$ & $<5$ \\
WS30(\#1) & $<5$ & $<5$ & $<5$ & $<5$ \\
WS30(\#2) & $<5$ & $<5$ & $<5$ & $<5$ \\
WS35 & $<5$ & $<5$ & $<5$ & $<5$ \\
WS36 & $<5$ & $<5$ & $<5$ & $<5$ \\
WS37 & $<5$ & $<5$ & $<5$ & $<5$ \\
WS39 & $<5$ & 12.2 & $<5$ & $<5$ \\
CC01 & $<5$ & 5.17 & $<5$ & $<5$ \\
CC02 & $<5$ & 9.37 & $<5$ & ND \\
CC04 & $<5$ & $<5$ & $<5$ & ND \\
CC05 & $<5$ & $<5$ & $<5$ & $<5$ \\
CC07 & $<5$ & $<5$ & $<5$ \\
CC09 & $<5$ & $<5$ & $<5$ \\
CC10 & $<5$ & $<5$ & $<5$ \\
CC13 & $<5$ & $<5$ & $<5$ \\
CC16 & $<5$ & $<5$ & $<5$ \\
CC17 & $<5$ & $<5$ & $<.86$ \\
LMB01 & $<5$ & $<5$ & $<5$ & $<5$ \\
LMB02 & 7.79 & 16 & 9.14 & 6.37 \\
LMB05 & $<5$ & 4.68 & $<5$ & $<5$ \\
LMB12 & 9.13 & 22.1 & 7.68 & $<$ \\
\hline
\end{tabular}


Table 23. Mean survival and growth of the amphipod Hyalella azteca in 28-day exposures and of the midge Chironomus dilutus in 10-day exposures to sediment samples from the Charles River and to a control sediment. Standard deviation is reported within the parentheses $(n=3$ replicate assays; $\mathrm{mm}$, millimeters; $\mathrm{mg}$, milligrams).

\begin{tabular}{lcccccc}
\hline \multirow{2}{*}{ Treatment } & \multicolumn{2}{c}{ Hyalella azteca } & & \multicolumn{2}{c}{ Chironomus dilutus } \\
\cline { 2 - 3 } \cline { 5 - 6 } & Survival (percent) & Growth $(\mathrm{mm})$ & & Survival (percent) & Growth (mg) ${ }^{1}$ \\
\hline Control & $93(9.57)$ & $3.76(0.40)$ & & $85(12.58)$ & $1.10(0.48)$ \\
Charles River sample 1 & $90(14.14)$ & $4.01(.59)$ & & $78(18.93)$ & $.72(.19)$ \\
Charles River sample 2 & $58(23.63)$ & $3.35(.68)$ & & $78(5.00)$ & $.29(.12)$ \\
Charles River sample 3 & $80(8.16)$ & $3.49(.61)$ & & $98(17.32)$ & $.26(.04)$ \\
\hline
\end{tabular}

${ }^{1}$ Ash free dry weight. 
Table 24. Potential toxicity of extracts from semi-permeable membrane devices (SPMD) and from polar organic contaminant integrated samplers (POCIS) using the Microtox@ bioassay and the yeast estrogen screen (YES) bioassay. Standard deviations derived from three replicates are reported within the parentheses for the Microtox® bioassay. The concentration of the extract that inhibited luminescence by 50 percent after a 5minute exposure period (the EC50) was determined and expressed as milligram ( $\mathrm{mg}$ ) equivalent sediment wet weight. The 17ß-estradiol equivalents (EEQ) screened by the YES bioassay are shown for SPMD and POCIS extracts. (NA, not applicable; $\mathrm{mg} / \mathrm{mL}$, milligrams per milliliter; $\mathrm{mL}$, milliliter; $\mathrm{ng} / \mathrm{mL}$, nanogram per milliliter)

\begin{tabular}{|c|c|c|c|c|c|c|c|c|}
\hline \multirow[b]{2}{*}{ Bioassay treatment } & \multicolumn{4}{|c|}{ SPMD } & \multicolumn{4}{|c|}{ POCIS } \\
\hline & $\begin{array}{l}\text { Field SPMD } \\
\text { blank }\end{array}$ & $\begin{array}{l}\text { Deployed } \\
\text { SPMD \#1 }\end{array}$ & $\begin{array}{l}\text { Deployed } \\
\text { SPMD \#2 }\end{array}$ & $\begin{array}{c}\text { Phenol } \\
\text { (toxicity } \\
\text { surrogate) }\end{array}$ & $\begin{array}{l}\text { Field } \\
\text { POCIS } \\
\text { blank }\end{array}$ & $\begin{array}{l}\text { Deployed } \\
\text { POCIS \#1 }\end{array}$ & $\begin{array}{l}\text { Deployed } \\
\text { POCIS \#2 }\end{array}$ & $\begin{array}{l}\text { Phenol } \\
\text { (toxicity } \\
\text { surrogate) }\end{array}$ \\
\hline \multicolumn{9}{|l|}{ Microtox $®$} \\
\hline $\mathrm{EC}_{50}(\mathrm{mg} / \mathrm{mL})$ & $58(16)$ & $21(3.6)$ & $19(2.4)$ & $0.02(0.002)$ & $18(6.8)$ & $4.2(3.5)$ & $7.3(1.5)$ & $0.02(0.001)$ \\
\hline $\mathrm{TU}_{50}(\mathrm{mg} / \mathrm{mL})^{1}$ & 1.76 & 4.99 & 5.42 & 4,720 & 5.7 & 24 & 14 & 6,580 \\
\hline \multicolumn{9}{|l|}{ Yeast Estrogen Screen (YES) } \\
\hline $\mathrm{EC}_{50} \mathrm{E} 2(\mathrm{M} \mathrm{E} 2)^{2}$ & $6.7 \times 10^{-10}$ & $1.2 \times 10^{-9}$ & $6.7 \times 10^{-10}$ & NA & $1.1 \times 10^{-9}$ & $1.2 \times 10^{-9}$ & $1.2 \times 10^{-9}$ & NA \\
\hline $\mathrm{EC}_{50} \mathrm{E} 2(\mathrm{ng} / \mathrm{mL} \mathrm{E} 2)$ & 180 & 330 & 180 & NA & 290 & 310 & 310 & NA \\
\hline $\mathrm{EC}_{50}$ test (mg SPMD or mg POCIS) ${ }^{3}$ & 510 & 140 & 61 & NA & 77 & 4.4 & 4.2 & NA \\
\hline $\begin{array}{l}\mathrm{EC}_{50} \text { test (percent SPMD or percent } \\
\text { POCIS) }\end{array}$ & 11 & 3.1 & 1.4 & NA & 19 & 1.1 & 1 & NA \\
\hline EEQ (ng E2/SPMD or ng E2/POCIS) ${ }^{4}$ & 1.6 & 11 & 13 & NA & 1.5 & 29 & 30 & NA \\
\hline
\end{tabular}

${ }^{1}$ Toxic units $(\mathrm{TU})=\left(1 / \mathrm{EC}_{50}\right) \times 100$. This provides a measure of toxicity in the extract. Higher TU number indicates more potential toxicity.

${ }^{2} \mathrm{EC}_{50} \mathrm{E} 2$ : effective median concentration of $17 \beta$-estradiol producing 50 percent of the maximum response for the expression of lac- $\mathrm{Z}$ reporter gene of the yeast assay.

${ }^{3} \mathrm{EC}_{50}$ test: concentration of sample needed to give a response equivalent to the $\mathrm{EC}_{50} \mathrm{E} 2$.

${ }^{4} \mathrm{EEQ}(\mathrm{ng}$ E2/sampler $)=\mathrm{EC}_{50} \mathrm{E} 2(\mathrm{ng} \mathrm{E} 2 / \mathrm{mL}) / \mathrm{EC}_{50}$ test $($ sampler $/ \mathrm{mL})$, where sampler $/ \mathrm{mL}=$ percent sampler $\times 1 \mathrm{~mL}$ sample. 
Table 25. Gender, stage, sex steroid hormones, vitellogenin, and thyroid hormones in blood plasma of common carp (CC), largemouth bass (LMB), and white suckers (WS) collected from the Charles River (August, 2005). (E2, 17ß-estradiol; 11KT, 11-ketotestosterone; T3, triiodothyronine; T4, hyroxine; ND, Not Determined; pg/mL, picograms per millilitre; mg/mL, milligrams per milliliter; $\mathrm{ng} / \mathrm{mL}$, nanograms per milliter)

\begin{tabular}{|c|c|c|c|c|c|c|c|c|c|}
\hline \multirow[b]{2}{*}{ Species } & \multirow[b]{2}{*}{ Gender } & \multirow[b]{2}{*}{ Stage $^{1}$} & \multirow[b]{2}{*}{ Fish ID } & \multicolumn{3}{|c|}{ Sex steroid hormones ${ }^{2}$} & \multirow[b]{2}{*}{$\begin{array}{c}\text { Vitellogenin } \\
(\mathrm{mg} / \mathrm{mL})\end{array}$} & \multicolumn{2}{|c|}{ Thyroid hormones ${ }^{4}$} \\
\hline & & & & $\begin{array}{c}\text { E2 } \\
\text { (pg/mL) }\end{array}$ & $\begin{array}{c}11 \mathrm{KT} \\
(\mathrm{pg} / \mathrm{mL})\end{array}$ & E2/11KT & & $\mathrm{T} 3$ (ng/mL) & $\begin{array}{c}\text { T4 } \\
\text { (ng/mL) }\end{array}$ \\
\hline Common carp & $\mathrm{F}$ & 3 & $\mathrm{CC} 03$ & 266 & 371 & 0.72 & 2.739 & 10.4 & 1.1 \\
\hline Common carp & $\mathrm{F}$ & 3 & $\mathrm{CC} 04$ & 354 & 120 & 2.95 & 3.021 & 11.1 & 3.4 \\
\hline Common carp & $\mathrm{F}$ & 3 & $\mathrm{CC} 06$ & 284 & 333 & .85 & 3.3 & 12.7 & 9.9 \\
\hline Common carp & $\mathrm{F}$ & 3 & $\mathrm{CC} 07$ & 471 & 169 & 2.79 & 3.598 & 11.1 & 12.3 \\
\hline Common carp & $\mathrm{F}$ & ND & $\mathrm{CC} 09$ & 316 & 148 & 2.14 & 5.148 & 8.9 & 14.5 \\
\hline Common carp & $\mathrm{F}$ & 3 & $\mathrm{CC} 16$ & 328 & 229 & 1.43 & 5.594 & 8 & 8.7 \\
\hline Common carp & $\mathrm{F}$ & 3 & $\mathrm{CC} 17$ & 599 & 279 & 2.15 & 1.59 & 9.9 & 15.9 \\
\hline Common carp & $\mathrm{F}$ & 3 & $\mathrm{CC} 18$ & 409 & 155 & 2.64 & 4.183 & 8.2 & 20.9 \\
\hline Common carp & $\mathrm{F}$ & 3 & $\mathrm{CC} 19$ & 290 & 264 & 1.1 & 2.383 & 12.4 & 17.5 \\
\hline Common carp & $\mathrm{F}$ & 3 & $\mathrm{CC} 20$ & 277 & 284 & .98 & 2.727 & 12.4 & 30.2 \\
\hline Common carp & $\mathrm{M}$ & 2 & $\mathrm{CC} 01$ & 287 & 374 & .77 & .017 & 1.9 & 14.2 \\
\hline Common carp & M & 3 & $\mathrm{CC} 02$ & 334 & 404 & .83 & .008 & 1.8 & 4.4 \\
\hline Common carp & $\mathrm{M}$ & 3 & $\mathrm{CC} 05$ & 266 & 261 & 1.02 & .002 & 13.2 & 12.5 \\
\hline Common carp & $\mathrm{M}$ & late 2 & $\mathrm{CC} 08$ & 180 & 154 & 1.17 & .004 & 9.1 & 6.2 \\
\hline Common carp & $\mathrm{M}$ & 2 & $\mathrm{CC} 10$ & 203 & 102 & 1.99 & .006 & 8.5 & 14.3 \\
\hline Common carp & $\mathrm{M}$ & 3 & $\mathrm{CC} 11$ & 453 & 150 & 3.02 & .007 & 6.8 & 22.8 \\
\hline Common carp & M & 3 & $\mathrm{CC} 12$ & 517 & 824 & .63 & .005 & 5.7 & 13.6 \\
\hline Common carp & $\mathrm{M}$ & late 2 & $\mathrm{CC} 13$ & 187 & 104 & 1.8 & .005 & 7 & 19.4 \\
\hline Common carp & $\mathrm{M}$ & 2 & $\mathrm{CC} 14$ & 195 & 356 & .55 & .009 & 6 & 9.3 \\
\hline Common carp & $\mathrm{M}$ & late 2 & $\mathrm{CC} 15$ & 144 & 119 & 1.21 & .012 & 10.5 & 34.3 \\
\hline Largemouth bass & $\mathrm{F}$ & 1 & LMB01 & 407 & 407 & 1 & 0 & 38.3 & 9.5 \\
\hline Largemouth bass & $\mathrm{F}$ & 2 & LMB02 & 373 & 448 & .83 & 0 & 30.2 & 13.1 \\
\hline Largemouth bass & $\mathrm{F}$ & 3 & LMB03 & 298 & 429 & .69 & 0 & 39.5 & 9.9 \\
\hline Largemouth bass & $\mathrm{F}$ & 0 & LMB07 & 345 & 397 & .87 & 0 & 26.4 & 9.8 \\
\hline
\end{tabular}


Table 25. Gender, stage, sex steroid hormones, vitellogenin, and thyroid hormones in blood plasma of common carp (CC), largemouth bass (LMB), and white suckers (WS) collected from the Charles River (August, 2005). (E2, 17ß-estradiol; 11KT, 11-ketotestosterone; T3, triiodothyronine; T4, hyroxine; ND, Not Determined; $\mathrm{pg} / \mathrm{mL}$, picograms per millilitre; $\mathrm{mg} / \mathrm{mL}$, milligrams per milliliter; $\mathrm{ng} / \mathrm{mL}$, nanograms per milliter)-Continued

\begin{tabular}{|c|c|c|c|c|c|c|c|c|c|}
\hline \multirow[b]{2}{*}{ Species } & \multirow[b]{2}{*}{ Gender } & \multirow[b]{2}{*}{ Stage $e^{1}$} & \multirow[b]{2}{*}{ Fish ID } & \multicolumn{3}{|c|}{ Sex steroid hormones ${ }^{2}$} & \multirow{2}{*}{$\begin{array}{c}\text { Vitellogenin } \\
\text { (mg/mL) }\end{array}$} & \multicolumn{2}{|c|}{ Thyroid hormones ${ }^{4}$} \\
\hline & & & & $\begin{array}{c}\text { E2 } \\
\text { (pg/mL) }\end{array}$ & $\begin{array}{c}11 \mathrm{KT} \\
(\mathrm{pg} / \mathrm{mL})\end{array}$ & E2/11KT & & $\begin{array}{c}\mathrm{T} 3 \\
\text { (ng/mL) }\end{array}$ & $\begin{array}{c}\mathrm{T} 4 \\
(\mathrm{ng} / \mathrm{mL})\end{array}$ \\
\hline Largemouth bass & $\mathrm{F}$ & 1 & LMB11 & 329 & 347 & .95 & 0 & 42.1 & 8.9 \\
\hline Largemouth bass & $\mathrm{F}$ & 0 & LMB12 & 482 & 454 & 1.06 & 0 & 41.5 & 5.7 \\
\hline Largemouth bass & $\mathrm{F}$ & 1 & LMB14 & ND & ND & ND & 0 & 36.5 & 7.8 \\
\hline Largemouth bass & $\mathrm{F}$ & 2 & LMB16 & 379 & 351 & 1.08 & .003 & 25.6 & 4.6 \\
\hline Largemouth bass & M & 3 & LMB04 & 328 & 470 & .7 & 0 & 15.4 & 10.5 \\
\hline Largemouth bass & M & 3 & LMB05 & 302 & 471 & .64 & 0 & 28.9 & 12.6 \\
\hline Largemouth bass & M & 2 & LMB06 & 370 & 559 & .66 & 0 & 34.6 & 7.5 \\
\hline Largemouth bass & M & 2 & LMB08 & 385 & 366 & 1.05 & 0 & 25.3 & 13.3 \\
\hline Largemouth bass & M & 2 & LMB09 & 339 & 478 & .71 & 0 & 31.5 & 7.9 \\
\hline Largemouth bass & M & 2 & LMB10 & 381 & 389 & .98 & .03 & 43.8 & 10.5 \\
\hline Largemouth bass & M & 3 & LMB13 & 431 & 449 & .96 & 0 & 31.7 & 6.9 \\
\hline Largemouth bass & M & 1 & LMB15 & 405 & 416 & .97 & 0 & 35.3 & 5.6 \\
\hline Largemouth bass & M & 1 & LMB17 & 278 & 312 & .89 & 0 & 19.9 & 3.3 \\
\hline Largemouth bass & M & 3 & LMB18 & ND & ND & ND & .011 & 29.9 & 9.9 \\
\hline Largemouth bass & M & 2 & LMB19 & 333 & 218 & 1.53 & 0 & 54.5 & 20.5 \\
\hline Largemouth bass & M & 1 & LMB20 & ND & ND & ND & 0 & 1.1 & 13.4 \\
\hline White sucker & $\mathrm{F}$ & 2 & WS01 & 380 & 179 & 2.12 & .466 & 6 & 12.2 \\
\hline White sucker & $\mathrm{F}$ & 2 & WS02 & 445 & 128 & 3.48 & .38 & 3.2 & 5.4 \\
\hline White sucker & $\mathrm{F}$ & 2 & WS03 & 647 & 136 & 4.76 & .726 & 5.5 & 11.5 \\
\hline White sucker & $\mathrm{F}$ & 2 & WS04 & 398 & 123 & 3.24 & .314 & 8.9 & 7.6 \\
\hline White sucker & $\mathrm{F}$ & late 2 & WS05 & 412 & 142 & 2.9 & 2.26 & 19.9 & 19.4 \\
\hline White sucker & $\mathrm{F}$ & 2 & WS06 & 383 & 122 & 3.14 & .066 & 7.6 & 7.5 \\
\hline White sucker & $\mathrm{F}$ & late 2 & WS07 & 411 & 124 & 3.31 & .244 & 5.5 & 6.7 \\
\hline White sucker & $\mathrm{F}$ & late 2 & WS08 & 226 & 419 & .54 & .563 & 9.7 & 1.5 \\
\hline
\end{tabular}


Table 25. Gender, stage, sex steroid hormones, vitellogenin, and thyroid hormones in blood plasma of common carp (CC), largemouth bass (LMB), and white suckers (WS) collected from the Charles River (August, 2005). (E2, 17ß-estradiol; 11KT, 11-ketotestosterone; T3, triiodothyronine; T4, hyroxine; ND, Not Determined; $\mathrm{pg} / \mathrm{mL}$, picograms per millilitre; $\mathrm{mg} / \mathrm{mL}$, milligrams per milliliter; $\mathrm{ng} / \mathrm{mL}$, nanograms per milliter)-Continued

\begin{tabular}{|c|c|c|c|c|c|c|c|c|c|}
\hline \multirow[b]{2}{*}{ Species } & \multirow[b]{2}{*}{ Gender } & \multirow[b]{2}{*}{ Stage ${ }^{1}$} & \multirow[b]{2}{*}{ Fish ID } & \multicolumn{3}{|c|}{ Sex steroid hormones ${ }^{2}$} & \multirow{2}{*}{$\begin{array}{l}\text { Vitellogenin } \\
\text { (mg/mL) }\end{array}$} & \multicolumn{2}{|c|}{ Thyroid hormones ${ }^{4}$} \\
\hline & & & & $\begin{array}{c}E 2 \\
(\mathrm{pg} / \mathrm{mL})\end{array}$ & $\begin{array}{c}11 \mathrm{KT} \\
(\mathrm{pg} / \mathrm{mL})\end{array}$ & E2/11KT & & $\begin{array}{c}\mathrm{T} 3 \\
\text { (ng/mL) }\end{array}$ & $\begin{array}{c}\mathrm{T} 4 \\
\text { (ng/mL) }\end{array}$ \\
\hline White sucker & $\bar{F}$ & 2 & WS09 & 752 & 193 & 3.9 & .69 & 8.1 & 5.9 \\
\hline White sucker & $\mathrm{F}$ & late 2 & WS10 & 286 & 120 & 2.38 & .504 & 11.5 & 6.9 \\
\hline White sucker & $\mathrm{F}$ & late 2 & WS11 & 116 & 217 & .53 & .074 & 13.4 & 11.5 \\
\hline White sucker & $\mathrm{F}$ & 2 & WS12 & 207 & 195 & 1.06 & .722 & 11.2 & 15.4 \\
\hline White sucker & $\mathrm{F}$ & 2 & WS13 & 432 & 163 & 2.65 & .35 & 10.8 & 12.6 \\
\hline White sucker & $\mathrm{F}$ & late 2 & WS14 & 289 & 134 & 2.16 & .552 & 10.7 & 12.9 \\
\hline White sucker & $\mathrm{F}$ & 2 & WS15 & 212 & 125 & 1.7 & .846 & 15.1 & 10.3 \\
\hline White sucker & $\mathrm{F}$ & 2 & WS17 & 226 & 506 & .45 & .624 & 8.9 & 11.8 \\
\hline White sucker & $\mathrm{F}$ & ND & WS18 & 254 & 95 & 2.67 & .584 & 11 & 14.8 \\
\hline White sucker & $\mathrm{F}$ & 2 & WS19 & 266 & 157 & 1.69 & .845 & 6.1 & 17.5 \\
\hline White sucker & $\mathrm{F}$ & 2 & WS21 & 126 & 161 & .78 & 0 & 12.3 & 22.7 \\
\hline White sucker & $\mathrm{F}$ & 2 & WS24 & 315 & 451 & .7 & 1.35 & 10.7 & 11.9 \\
\hline White sucker & $\mathrm{F}$ & 2 & WS25 & 225 & 241 & .93 & .243 & 4.4 & 4.5 \\
\hline White sucker & $\mathrm{F}$ & 2 & WS26 & 114 & 303 & .38 & .907 & 20.2 & 17.9 \\
\hline White sucker & $\mathrm{F}$ & late 2 & WS29 & 159 & 735 & .22 & .695 & 5.7 & 20.5 \\
\hline White sucker & $\mathrm{F}$ & 2 & WS30 & 226 & 105 & 2.15 & .415 & 7.3 & 5.5 \\
\hline White sucker & $\mathrm{F}$ & 2 & WS31 & 155 & 127 & 1.22 & .982 & 6.6 & 10.3 \\
\hline White sucker & $\mathrm{F}$ & 2 & WS32 & 174 & 873 & .2 & .456 & 2.6 & 7.1 \\
\hline White sucker & $\mathrm{F}$ & early 2 & WS34 & 153 & 136 & 1.13 & 1.159 & 8.1 & 21.3 \\
\hline White sucker & $\mathrm{F}$ & early 2 & WS36 & 35 & 118 & .3 & .664 & 4.8 & 11.1 \\
\hline White sucker & $\mathrm{F}$ & 2 & WS37 & 260 & 101 & 2.57 & 1.114 & 4.6 & 2.9 \\
\hline White sucker & M & 1 & WS16 & 438 & 224 & 1.96 & 0 & 8.1 & 16.4 \\
\hline White sucker & M & early 1 & WS20 & 360 & 983 & .37 & 0 & 2.4 & 20.7 \\
\hline White sucker & M & early 1 & WS22 & 47 & 1099 & .04 & 0 & 5.1 & 5.9 \\
\hline White sucker & M & early 1 & WS23 & 184 & 514 & .36 & .009 & 2.1 & 10.1 \\
\hline
\end{tabular}


Table 25. Gender, stage, sex steroid hormones, vitellogenin, and thyroid hormones in blood plasma of common carp (CC), largemouth bass (LMB), and white suckers (WS) collected from the Charles River (August, 2005). ((E2, 17ß-estradiol; 11KT, 11-ketotestosterone; $\mathrm{T} 3$, triiodothyronine; T4, hyroxine; ND, Not Determined; $\mathrm{pg} / \mathrm{mL}$, picograms per millilitre; $\mathrm{mg} / \mathrm{mL}$, milligrams per milliliter; $\mathrm{ng} / \mathrm{mL}$, nanograms per milliter)-Continued

\begin{tabular}{|c|c|c|c|c|c|c|c|c|c|}
\hline \multirow[b]{2}{*}{ Species } & \multirow[b]{2}{*}{ Gender } & \multirow[b]{2}{*}{ Stage ${ }^{1}$} & \multirow[b]{2}{*}{ Fish ID } & \multicolumn{3}{|c|}{ Sex Steroid Hormones ${ }^{2}$} & \multirow{2}{*}{$\begin{array}{l}\text { Vitellogenin }{ }^{3} \\
(\mathrm{mg} / \mathrm{mL})\end{array}$} & \multicolumn{2}{|c|}{ Thyroid Hormones ${ }^{4}$} \\
\hline & & & & $\begin{array}{c}E 2 \\
(p g / m L)\end{array}$ & $\begin{array}{c}11 \mathrm{KT} \\
(\mathrm{pg} / \mathrm{mL})\end{array}$ & $\mathrm{E} 2 / 11 \mathrm{KT}$ & & $\begin{array}{c}\text { T3 } \\
\text { (ng/mL) }\end{array}$ & $\begin{array}{c}\mathrm{T} 4 \\
\text { (ng/mL) }\end{array}$ \\
\hline White sucker & $\mathrm{M}$ & early 1 & WS27 & 174 & 866 & .20 & 0 & 9.2 & 21.0 \\
\hline White sucker & M & early 1 & WS28 & 218 & 491 & .44 & 0 & 6.2 & 14.2 \\
\hline White sucker & M & 1 & WS35 & 288 & 297 & .97 & 0 & 6.7 & 25.4 \\
\hline White sucker & M & late 1 & WS38 & 159 & 731 & .22 & 0 & 2.2 & 19.3 \\
\hline White sucker & M & early 1 & WS39 & 107 & 1,142 & .09 & 0 & 3.9 & 4.4 \\
\hline White sucker & M & 1 & WS40 & 452 & 735 & .61 & .005 & 12.0 & 21.7 \\
\hline
\end{tabular}

${ }^{\mathrm{T}}$ Females: Stage $0=$ undeveloped ovaries; Stage $1=$ early vitellogenic; Stage $2=$ early-mid vitellogenic; Stage $3=$ late vitellogenic; Stage $4=$ late vetellogenic, post ovulatory; Stage $5=$ post vitellogenic. Males: Stage $0=$ undeveloped; Stage $1=$ early spermatogenic; Stage $2=$ mid spermatogenic; Stage $3=$ late spermatogenic.

${ }^{2} 17 ß$-estradiol (E2) and 11-ketotestosterone (11KT) determined using radioimmunoassay (RIA).

${ }^{3}$ Vitellogenin assayed and quantified by capture ELISA (enzyme-linked immunosorbent assay). Level of detection was $0.001 \mathrm{mg} / \mathrm{mL}$ for bass and $0.0005 \mathrm{mg} / \mathrm{mL}$ for carp and white suckers.

${ }^{4} \mathrm{~T} 3$ and $\mathrm{T} 4$ were determined using RIA and ELISA procedures. 
Table 26. Fecundity (estimated total number of oocytes per gonad) of female common carp collected from the Charles River (August, 2005). (ND, Not Determined; g, grams)

\begin{tabular}{ccccc}
\hline Fish ID & Stage $^{1}$ & Age (years) & Ovary weight $\mathbf{( g )}$ & Fecundity \\
\hline CC03 & 3 & 4 & 144.7 & 226,094 \\
CC07 & 5 & 7 & 270.6 & 465,749 \\
CC09 & ND & 6 & 855.0 & 467,213 \\
CC16 & 3 & 7 & 343.7 & 533,696 \\
CC17 & 3 & 3 & 184.1 & 481,937 \\
CC18 & 3 & 6 & 158.5 & 170,797 \\
CC19 & 3 & 5 & 213.4 & 229,957 \\
CC20 & 3 & 7 & 153.3 & 189,259 \\
\hline
\end{tabular}

${ }^{\mathrm{T}}$ Stage 0 = undeveloped ovaries; Stage $1=$ early vitellogenic; Stage 2 = early-mid vitellogenic; Stage 3 = late vitellogenic; Stage 4 = late vetellogenic, post ovulatory; Stage $5=$ post vitellogenic. 
Table 27. Sperm-quality metrics estimated for male common carp collected from the Charles River (August, 2005). (g, grams)

\begin{tabular}{lcccccc}
\hline Fish ID & $\begin{array}{c}\text { Testes } \\
\text { weight }(\mathbf{g})\end{array}$ & Age & Stage & Sperm concentration1 & $\begin{array}{c}\text { Progressive } \\
\text { status }^{2}\end{array}$ & $\begin{array}{c}\text { Percent } \\
\text { motility }^{3}\end{array}$ \\
\hline CC01 & 122.7 & 3 & 2 & intermediate & 2.5 & 45 \\
CC02 & 297.0 & 4 & 3 & high & 4 & 80 \\
CC05 & 151.0 & 3 & 3 & high & 2 & 65 \\
CC08 & 115.0 & 3 & late 2 & high & 2.5 & 75 \\
CC10 & 251.0 & 6 & 2 & high & 3 & 55 \\
CC12 & 261.8 & 4 & 3 & high & 3.5 & 85 \\
CC13 & 224.1 & 6 & late 2 & high & 3.5 & 70 \\
CC14 & 113.2 & 3 & 2 & high & 2.5 & 55 \\
CC15 & 261.7 & 7 & late 2 & high & 2 & 45 \\
\hline
\end{tabular}

${ }^{\mathrm{T}}$ Qualitative estimate of sperm concentration based on a fixed sample.

${ }^{2}$ Estimate of sperm movement/status on a scale of 1 to 5 .

${ }^{3}$ Estimate of the percent of total sperm actively moving. 
Table 28. Types of lesions and anomalies observed during histological examination and the percentage of common carp, largemouth bass, and white suckers affected.

\begin{tabular}{|c|c|c|c|c|}
\hline \multirow[b]{2}{*}{ Tissues examined } & \multirow{2}{*}{$\begin{array}{l}\text { Observations and types } \\
\text { of lesions and anomalies }\end{array}$} & \multicolumn{3}{|c|}{ Percentage of fish affected ${ }^{1}$} \\
\hline & & $\begin{array}{l}\text { Common } \\
\text { carp }\end{array}$ & $\begin{array}{l}\text { Largemouth } \\
\text { bass }\end{array}$ & White sucker \\
\hline \multirow[t]{10}{*}{ Liver } & Hepatocellular changes & & & \\
\hline & Megalocytosis & 5 & 5 & 0 \\
\hline & Karyomegaly & 1 & 0 & 0 \\
\hline & Diffuse vacuolation & 15 & 5 & 55 \\
\hline & Focal vacuolation & 0 & 0 & 18 \\
\hline & Spongiosis & 5 & 0 & 18 \\
\hline & Oval cell foci & 15 & 0 & 33 \\
\hline & Inflammation & 100 & 65 & 40 \\
\hline & Biliary Lesions & 20 & 20 & 45 \\
\hline & Tumors & 0 & 5 & 7 \\
\hline Peritoneum & Peritonitis (inflammation) & 85 & 45 & 60 \\
\hline \multirow{2}{*}{ Gonads } & Parasitic Orchitis & 70 & 25 & 18 \\
\hline & Follicular Atresia & 38 & 90 & 7 \\
\hline \multirow[t]{7}{*}{ Spleen } & Necrosis/lymphoid depletion & 5 & 0 & 0 \\
\hline & Parasitic granulomas & 80 & 0 & 2.5 \\
\hline & Oval cell foci & 5 & 0 & 36 \\
\hline & Hemosiderosis & 5 & 0 & 2.5 \\
\hline & Hemorrhage & 5 & 0 & 2.5 \\
\hline & Hematomas & 0 & 5 & 2.5 \\
\hline & Sponiosis & 0 & 5 & 0 \\
\hline \multirow[t]{7}{*}{ Kidney } & Inflammation/necrosis & 37 & 0 & 2.5 \\
\hline & Calcinosis & 5 & 0 & 0 \\
\hline & Plerocercoids & 63 & 0 & 0 \\
\hline & Myxosporean & 37 & 0 & 0 \\
\hline & Nematode granulomas & 63 & 11 & 10 \\
\hline & Oval cell foci & 5 & 0 & 43 \\
\hline & Tubular/glomerular degeneration & 0 & 11 & 8 \\
\hline
\end{tabular}

${ }^{1}$ Number of fish examined for liver and peritoneum lesions and anomalies was: 20 largemouth bass, 20 common carp, and 40 white suckers. Spleen tissue from 20 largemouth bass, 19 common carp, and 40 white suckers was examined. Kidney tissue from 19 largemouth bass, 19 common carp, and 40 white suckers was examined and gonad tissue from 20 largemouth bass, 20 common carp and 39 white suckers. Gonad tissue from 8 female largemouth bass, 10 female common carp, and 28 female was suckers were also examined for follicular atresia. 
Table 29. Density and mean surface size of melanomacrophage centers (MMC) located in the liver, spleen, and renal kidney from common carp, largemouth bass, and white suckers collected from the Charles River (August, 2005). (NC, tissue not collected; NO, MMCs containing at least 12 cells were not observed)

\begin{tabular}{|c|c|c|c|c|c|c|c|}
\hline \multirow[b]{2}{*}{ Species } & \multirow[b]{2}{*}{ Fish ID } & \multicolumn{2}{|c|}{ Liver } & \multicolumn{2}{|c|}{ Spleen } & \multicolumn{2}{|c|}{ Renal kidney } \\
\hline & & $\begin{array}{c}\text { MMC1 }^{1} \\
\text { density }{ }^{2}\end{array}$ & $\begin{array}{c}\text { Mean } \\
\text { surface }^{3}\end{array}$ & $\begin{array}{c}\text { MMC } \\
\text { density }^{2}\end{array}$ & $\begin{array}{c}\text { Mean } \\
\text { surface }^{3}\end{array}$ & $\begin{array}{c}\text { MMC } \\
\text { density }^{2}\end{array}$ & $\begin{array}{c}\text { Mean } \\
\text { surface }^{3}\end{array}$ \\
\hline Common carp & $\mathrm{CC} 01$ & 3.9 & $6,420.5$ & 8.0 & 9,638 & $\mathrm{NO}$ & $\mathrm{NO}$ \\
\hline Common carp & $\mathrm{CC} 02$ & 6.2 & $18,369.2$ & 10.0 & $15,910.7$ & $\mathrm{NC}$ & $\mathrm{NC}$ \\
\hline Common carp & $\mathrm{CC} 03$ & 1.9 & $10,105.5$ & 14.2 & $17,973.7$ & .3 & $5,699.0$ \\
\hline Common carp & $\mathrm{CC} 04$ & 4.2 & $2,864.9$ & 9.8 & $28,005.2$ & $\mathrm{NC}$ & $\mathrm{NC}$ \\
\hline Common carp & $\mathrm{CC} 05$ & .2 & $3,541.1$ & 11.6 & $5,172.8$ & .7 & $15,518.0$ \\
\hline Common carp & $\mathrm{CC} 06$ & .2 & $4,873.3$ & 6.6 & $4,667.8$ & .2 & $6,403.5$ \\
\hline Common carp & $\mathrm{CC} 07$ & 2.8 & $2,589.5$ & 9.0 & 8,862 & $\mathrm{NC}$ & $\mathrm{NC}$ \\
\hline Common carp & $\mathrm{CC} 08$ & .6 & $4,451.7$ & 6.1 & 5,784 & 1.3 & $4,614.4$ \\
\hline Common carp & $\mathrm{CC} 09$ & 1.7 & $4,525.7$ & 10.7 & $12,541.7$ & 1.9 & $5,508.2$ \\
\hline Common carp & $\mathrm{CC} 10$ & 3.1 & $7,464.6$ & 10.9 & $12,793.7$ & $\mathrm{NC}$ & $\mathrm{NC}$ \\
\hline Common carp & $\mathrm{CC} 11$ & 4.2 & $5,489.8$ & 10.4 & $7,969.8$ & 1.0 & $6,847.3$ \\
\hline Common carp & $\mathrm{CC} 12$ & 5.0 & $5,322.1$ & 10.1 & 4,397 & 1.7 & $11,523.8$ \\
\hline Common carp & CC13 & 1.0 & $3,843.0$ & 4.2 & $3,539.9$ & $\mathrm{NC}$ & $\mathrm{NC}$ \\
\hline Common carp & $\mathrm{CC} 14$ & 1.3 & $5,131.8$ & 1.9 & $1,940.7$ & 1.0 & $5,585.8$ \\
\hline Common carp & $\mathrm{CC} 15$ & 2.0 & $5,773.1$ & 12.2 & $6,023.7$ & 2.6 & $4,196.5$ \\
\hline Common carp & $\mathrm{CC} 16$ & 1.0 & $4,206.2$ & 5.6 & $5,404.1$ & $\mathrm{NC}$ & $\mathrm{NC}$ \\
\hline Common carp & $\mathrm{CC} 17$ & 1.2 & $6,645.3$ & 8.2 & $6,877.4$ & $\mathrm{NC}$ & $\mathrm{NC}$ \\
\hline Common carp & $\mathrm{CC} 18$ & 1.2 & $3,168.9$ & 9.3 & $11,077.4$ & $\mathrm{NC}$ & $\mathrm{NC}$ \\
\hline Common carp & CC19 & .4 & $2,625.3$ & $\mathrm{NC}$ & $\mathrm{NC}$ & $\mathrm{NO}$ & $\mathrm{NO}$ \\
\hline Common carp & $\mathrm{CC} 20$ & .6 & $4,848.2$ & 8.3 & $11,161.3$ & $\mathrm{NC}$ & $\mathrm{NC}$ \\
\hline Largemouth bass & LMB01 & 5.3 & $15,088.2$ & 7.6 & $9,602.6$ & 7.0 & $11,458.3$ \\
\hline Largemouth bass & LMB02 & 1.1 & $4,331.2$ & 3.8 & $3,619.9$ & 5.2 & $3,193.2$ \\
\hline Largemouth bass & LMB03 & 4.8 & $15,847.6$ & 10.2 & $5,889.6$ & 7.2 & $4,678.3$ \\
\hline Largemouth bass & LMB04 & 8.2 & $14,102.9$ & 6.7 & $9,499.2$ & $\mathrm{NC}$ & $\mathrm{NC}$ \\
\hline Largemouth bass & LMB05 & .3 & $3,037.9$ & 1.9 & $2,142.9$ & 1.9 & $1,475.1$ \\
\hline Largemouth bass & LMB06 & .0 & $1,824.0$ & 2.7 & $1,502.4$ & .9 & $1,454.7$ \\
\hline Largemouth bass & LMB07 & .0 & $5,426.0$ & .3 & $1,228.1$ & .4 & $1,399.0$ \\
\hline Largemouth bass & LMB08 & .1 & $1,598.3$ & .9 & 1,418 & 1.6 & $1,711.9$ \\
\hline Largemouth bass & LMB09 & .0 & 581.0 & 1.2 & 835.8 & .9 & $1,338.1$ \\
\hline Largemouth bass & LMB10 & 3.7 & $9,612.1$ & 11.4 & $5,177.3$ & 10.9 & $6,199.7$ \\
\hline Largemouth bass & LMB11 & 1.2 & $3,705.9$ & 4.3 & $2,773.3$ & $\mathrm{NC}$ & $\mathrm{NC}$ \\
\hline Largemouth bass & LMB12 & 5.9 & $5,309.2$ & 9.2 & $2,671.7$ & 9.4 & $4,386.8$ \\
\hline Largemouth bass & LMB13 & 2.0 & $4,638.9$ & 14.7 & $3,027.7$ & 4.9 & $4,387.1$ \\
\hline Largemouth bass & LMB14 & 1.3 & $3,973.7$ & 1.7 & $1,330.8$ & 3.0 & $1,996.0$ \\
\hline Largemouth bass & LMB15 & 3.2 & $13,297.8$ & 18.0 & $4,558.7$ & 6.7 & $5,069.6$ \\
\hline Largemouth bass & LMB16 & 3.6 & $9,305.9$ & 6.7 & $2,595.8$ & 6.3 & $2,553.8$ \\
\hline Largemouth bass & LMB17 & 1.4 & $3,353.2$ & 8.0 & $4,079.2$ & 5.2 & $3,165.5$ \\
\hline Largemouth bass & LMB18 & .6 & $2,964.5$ & 4.8 & $3,471.7$ & 2.6 & $2,786.0$ \\
\hline Largemouth bass & LMB19 & 1.4 & $5,411.2$ & 8.2 & $2,877.3$ & 3.4 & $2,950.0$ \\
\hline Largemouth bass & LMB20 & .4 & $1,968.4$ & 12.3 & $3,011.8$ & 3.9 & $2,372.7$ \\
\hline White sucker & WS01 & 7.0 & $4,893.9$ & 4.8 & $9,209.6$ & 6.6 & $3,137.1$ \\
\hline White sucker & WS02 & 6.6 & $3,126.3$ & 8.0 & 9,447 & 4.7 & $7,671.0$ \\
\hline
\end{tabular}


Table 29. Density and mean surface size of melanomacrophage centers (MMC) $)^{1}$ located in the liver, spleen, and renal kidney from common carp, largemouth bass, and white suckers collected from the Charles River (August, 2005). (NC, tissue not collected; NO, MMCs containing at least 12 cells were not observed)-Continued

\begin{tabular}{|c|c|c|c|c|c|c|c|}
\hline \multirow[b]{2}{*}{ Species } & \multirow[b]{2}{*}{ Fish ID } & \multicolumn{2}{|c|}{ Liver } & \multicolumn{2}{|c|}{ Spleen } & \multicolumn{2}{|c|}{ Renal kidney } \\
\hline & & $\begin{array}{c}\text { MMC } \\
\text { density }^{2}\end{array}$ & $\begin{array}{c}\text { Mean } \\
\text { surface }^{3}\end{array}$ & $\begin{array}{c}\text { MMC } \\
\text { density }\end{array}$ & $\begin{array}{c}\text { Mean } \\
\text { surface }^{3}\end{array}$ & $\begin{array}{c}\text { MMC } \\
\text { density }^{2}\end{array}$ & $\begin{array}{c}\text { Mean } \\
\text { surface }^{3}\end{array}$ \\
\hline White sucker & WS03 & 11.3 & $8,416.5$ & 11.7 & $5,697.1$ & 4.0 & $2,843.3$ \\
\hline White sucker & WS04 & 2.2 & $3,772.1$ & 19.0 & $8,125.2$ & 5.7 & $6,299.5$ \\
\hline White sucker & WS05 & .1 & 992.0 & 19.8 & $3,210.7$ & 4.0 & $1,804.9$ \\
\hline White sucker & WS06 & 3.3 & $1,643.1$ & 12.4 & $6,073.4$ & 7.9 & $4,039.5$ \\
\hline White sucker & WS07 & .8 & $2,111.2$ & 15.2 & $5,676.4$ & 7.7 & $5,976.9$ \\
\hline White sucker & WS08 & .0 & 702.0 & 15.1 & $2,496.6$ & 2.8 & $2,704.3$ \\
\hline White sucker & WS09 & 2.8 & $2,355.4$ & 17.0 & $3,901.3$ & 3.9 & $4,011.2$ \\
\hline White sucker & WS10 & $\mathrm{NO}$ & NO & 2.7 & $1,304.3$ & NO & NO \\
\hline White sucker & WS11 & $\mathrm{NO}$ & NO & 11.4 & $2,614.7$ & 3.0 & $3,131.1$ \\
\hline White sucker & WS12 & NO & NO & 6.0 & $1,836.1$ & 6 & $2,043.0$ \\
\hline White sucker & WS13 & .2 & $1,081.0$ & 9.1 & 5,290 & 2.1 & $2,707.4$ \\
\hline White sucker & WS14 & NO & NO & 8.9 & $3,400.2$ & $\mathrm{NC}$ & $\mathrm{NC}$ \\
\hline White sucker & WS15 & .3 & $2,174.0$ & 10.0 & $5,096.6$ & 2.6 & $2,551.8$ \\
\hline White sucker & WS16 & 2.0 & $5,327.2$ & 15.4 & $7,044.9$ & 12.1 & $3,470.8$ \\
\hline White sucker & WS17 & .3 & $3,894.1$ & 14.9 & $18,569.1$ & 5.9 & $4,849.3$ \\
\hline White sucker & WS18 & .3 & $1,248.3$ & 7.8 & $2,690.7$ & 2.3 & $3,131.3$ \\
\hline White sucker & WS19 & $\mathrm{NO}$ & NO & 5.2 & $3,240.8$ & 7.6 & $4,230.0$ \\
\hline White sucker & WS20 & 1.4 & $19,030.4$ & 15.4 & $4,752.5$ & 6.9 & $4,658.8$ \\
\hline White sucker & WS 21 & NO & NO & 4.8 & 905.3 & 3.3 & $2,098.0$ \\
\hline White sucker & WS22 & 13.2 & $20,186.4$ & 20.7 & $23,781.4$ & 9.8 & $4,716.1$ \\
\hline White sucker & WS 23 & 1.2 & $2,853.5$ & 7.6 & $8,689.2$ & 5.9 & $3,662.0$ \\
\hline White sucker & WS24 & .7 & $14,416.3$ & 8.6 & $5,221.1$ & .2 & $6,505.0$ \\
\hline White sucker & WS25 & 1.8 & $2,200.9$ & 11.9 & $7,897.8$ & 4.6 & $3,502.3$ \\
\hline White sucker & WS26 & NO & NO & 2.3 & $2,294.1$ & .8 & $1,526.5$ \\
\hline White sucker & WS27 & $\mathrm{NO}$ & NO & 12.2 & $2,981.2$ & 2.9 & $2,129.0$ \\
\hline White sucker & WS28 & .9 & $3,082.0$ & 22.8 & $20,309.1$ & 7.0 & $4,084.5$ \\
\hline White sucker & WS29 & NO & NO & 10.1 & $4,824.8$ & 2.1 & $1,950.3$ \\
\hline White sucker & WS30 & 5.3 & $4,074.8$ & 10.3 & $2,850.9$ & 4.4 & $2,536.8$ \\
\hline White sucker & WS31 & .0 & $1,768.4$ & 3.4 & $1,635.1$ & NO & NO \\
\hline White sucker & WS32 & 3.1 & $15,392.2$ & 15.1 & $7,104.7$ & 5.9 & $5,154.4$ \\
\hline White sucker & WS33 & 4.3 & $5,424.9$ & 18.6 & $4,424.2$ & 2.6 & $3,787.1$ \\
\hline White sucker & WS34 & 2.3 & $2,421.7$ & 8.6 & $2,655.9$ & 3.1 & $2,341.9$ \\
\hline White sucker & WS35 & 1.7 & $8,745.1$ & 14.1 & $8,930.5$ & 5.1 & $2,742.0$ \\
\hline White sucker & WS36 & 2.7 & $2,564.8$ & 10.4 & $8,519.9$ & 1.6 & $2,171.4$ \\
\hline White sucker & WS37 & 13.6 & $7,836.2$ & 8.1 & $2,359.7$ & 2.7 & $2,497.4$ \\
\hline White sucker & WS38 & 10.2 & $6,954.5$ & 12.2 & 5,748 & 6.2 & $3,580.8$ \\
\hline White sucker & WS39 & NO & NO & 8.1 & $3,075.7$ & 5.0 & $3,214.3$ \\
\hline White sucker & WS40 & $\mathrm{NO}$ & NO & 5.8 & $2,713.4$ & 3.1 & $2,857.6$ \\
\hline
\end{tabular}

${ }^{1} \mathrm{MMC}$ : melano-macrophage centers of at least 12 pigmented cells.

${ }^{2} \mathrm{MMC}$ density: calculated as average \# of MMC in three fields in three sections (9 measurements) at 200×.

${ }^{3}$ Mean surface: mean surface of 10 MMC fields (in microns) measured at 200×. 
Table 30. Comet assay measurements taken on blood and liver cells collected from common carp (CC) and white suckers (WS) from the Charles River (August, 2005). (TL, tail length; TEM, tail extent moment; TDNA, percent damaged or fragmented deoxyribonucleic acid in comet tail; $\mu \mathrm{m}$, micrometer)

\begin{tabular}{|c|c|c|c|c|c|c|c|}
\hline Species & Fish ID & $\begin{array}{c}\text { Blood TDNA } \\
\text { (percent) }\end{array}$ & $\begin{array}{l}\text { Blood TEM } \\
\quad(\mu \mathrm{m})\end{array}$ & $\begin{array}{l}\text { Blood TL } \\
\quad(\mu \mathrm{m})\end{array}$ & $\begin{array}{c}\text { Liver } \\
\text { TDNA } \\
\text { (percent) }\end{array}$ & $\begin{array}{l}\text { Liver TEM } \\
\qquad(\mu \mathrm{m})\end{array}$ & $\begin{array}{c}\text { Liver TL } \\
(\mu \mathrm{m})\end{array}$ \\
\hline Common carp & $\mathrm{CC} 01$ & 21.63 & 11.63 & 37.19 & 19.71 & 7.58 & 25.77 \\
\hline Common carp & $\mathrm{CC} 02$ & 41.66 & 29.94 & 65.35 & 14.19 & 4.71 & 20.38 \\
\hline Common carp & $\mathrm{CC} 03$ & 16.38 & 8.62 & 37.22 & 21.20 & 10.12 & 37.43 \\
\hline Common carp & $\mathrm{CC} 04$ & 13.21 & 4.83 & 25.40 & 19.89 & 8.79 & 32.99 \\
\hline Common carp & $\mathrm{CC} 05$ & 8.41 & 1.13 & 6.98 & 26.86 & 13.37 & 38.87 \\
\hline Common carp & $\mathrm{CC} 06$ & 24.12 & 13.21 & 45.75 & 22.07 & 8.81 & 26.72 \\
\hline Common carp & $\mathrm{CC} 07$ & 19.54 & 10.51 & 34.37 & 22.11 & 8.98 & 27.35 \\
\hline Common carp & CC08 & 20.67 & 9.61 & 30.22 & 22.61 & 10.28 & 31.58 \\
\hline Common carp & $\mathrm{CC} 09$ & 15.16 & 7.83 & 35.36 & 24.17 & 10.35 & 28.64 \\
\hline Common carp & $\mathrm{CC} 10$ & 24.42 & 12.69 & 35.43 & 35.57 & 14.97 & 34.58 \\
\hline Common carp & $\mathrm{CC} 11$ & 24.44 & 10.48 & 28.43 & 18.24 & 7.43 & 32.17 \\
\hline Common carp & $\mathrm{CC} 12$ & 21.81 & 10.04 & 29.57 & 15.67 & 5.81 & 23.30 \\
\hline Common carp & $\mathrm{CC} 13$ & 27.95 & 14.96 & 38.92 & 14.05 & 6.90 & 32.75 \\
\hline Common carp & $\mathrm{CC} 14$ & 25.47 & 12.10 & 37.46 & 20.93 & 7.60 & 26.62 \\
\hline Common carp & $\mathrm{CC} 15$ & 26.02 & 12.03 & 35.43 & 26.52 & 11.17 & 33.41 \\
\hline Common carp & $\mathrm{CC} 16$ & 19.66 & 10.16 & 33.33 & 29.78 & 14.38 & 41.95 \\
\hline Common carp & $\mathrm{CC} 17$ & 24.52 & 13.97 & 44.54 & 34.01 & 17.40 & 41.58 \\
\hline Common carp & $\mathrm{CC} 18$ & 12.40 & 4.93 & 27.92 & 22.11 & 11.19 & 41.41 \\
\hline Common carp & $\mathrm{CC} 19$ & 13.21 & 5.16 & 28.85 & 27.99 & 12.66 & 36.32 \\
\hline Common carp & $\mathrm{CC} 20$ & 12.95 & 4.90 & 28.59 & 20.97 & 7.61 & 29.25 \\
\hline White sucker & WS01 & 12.46 & 4.46 & 30.18 & 15.31 & 7.40 & 24.83 \\
\hline White sucker & WS02 & 20.62 & 8.52 & 31.63 & 22.53 & 8.76 & 30.14 \\
\hline White sucker & WS03 & 18.89 & 8.00 & 32.21 & 15.12 & 5.74 & 28.93 \\
\hline White sucker & WS04 & 8.76 & 2.54 & 22.41 & 25.41 & 13.26 & 39.32 \\
\hline White sucker & WS05 & 8.44 & 2.10 & 19.10 & 15.41 & 6.79 & 28.12 \\
\hline White sucker & WS06 & 9.55 & 3.52 & 29.45 & 9.65 & 5.58 & 55.45 \\
\hline White sucker & WS07 & 8.43 & 1.95 & 15.14 & 19.41 & 10.37 & 35.96 \\
\hline White sucker & WS08 & 12.29 & 4.61 & 31.03 & 15.53 & 6.88 & 37.78 \\
\hline White sucker & WS09 & 41.60 & 31.27 & 62.27 & 9.65 & 5.58 & 55.45 \\
\hline White sucker & WS10 & 10.85 & 4.36 & 28.41 & 23.43 & 9.40 & 27.07 \\
\hline White sucker & WS11 & 14.68 & 6.09 & 38.42 & 12.06 & 4.34 & 23.01 \\
\hline White sucker & WS12 & 16.27 & 7.32 & 39.24 & 9.24 & 2.46 & 22.57 \\
\hline White sucker & WS13 & 15.79 & 6.76 & 38.20 & 16.90 & 8.54 & 31.58 \\
\hline White sucker & WS14 & 11.18 & 3.83 & 29.27 & 15.32 & 5.92 & 25.90 \\
\hline White sucker & WS15 & 8.60 & 1.86 & 18.09 & 15.98 & 6.60 & 24.00 \\
\hline White sucker & WS16 & 9.44 & 3.44 & 33.21 & 12.30 & 3.92 & 18.59 \\
\hline White sucker & WS17 & 10.76 & 3.58 & 29.77 & 19.32 & 8.26 & 32.15 \\
\hline White sucker & WS18 & 9.90 & 2.29 & 18.53 & 10.15 & 2.94 & 19.71 \\
\hline White sucker & WS19 & 10.35 & 2.71 & 22.83 & 14.85 & 5.90 & 25.04 \\
\hline White sucker & WS20 & 8.93 & 2.12 & 20.07 & 13.96 & 5.20 & 24.54 \\
\hline White sucker & WS21 & 6.64 & 1.14 & 14.09 & 8.62 & 2.34 & 17.62 \\
\hline White sucker & WS22 & 7.49 & 1.22 & 13.29 & 10.15 & 2.93 & 17.35 \\
\hline White sucker & WS23 & 8.04 & 1.78 & 20.51 & 15.25 & 4.98 & 25.49 \\
\hline White sucker & WS24 & 6.11 & 1.75 & 20.86 & 11.20 & 3.77 & 20.07 \\
\hline White sucker & WS25 & 8.16 & 2.03 & 20.17 & 18.96 & 7.74 & 26.73 \\
\hline White sucker & WS26 & 6.98 & 2.04 & 24.26 & 21.75 & 10.69 & 35.79 \\
\hline White sucker & WS27 & 11.00 & 3.27 & 23.76 & 23.82 & 12.57 & 34.11 \\
\hline White sucker & WS28 & 8.26 & 2.39 & 26.17 & 14.85 & 5.90 & 22.99 \\
\hline
\end{tabular}


Table 30. Comet assay measurements taken on blood and liver cells collected from common carp (CC) and white suckers (WS) from the Charles River (August, 2005). (TL, tail length; TEM, tail extent moment; TDNA, percent damaged or fragmented deoxyribonucleic acid in comet tail; $\mu \mathrm{m}$, micrometer)-Continued

\begin{tabular}{lccccrrr}
\hline Species & Fish ID & $\begin{array}{c}\text { Blood TDNA } \\
\text { ( percent) }\end{array}$ & $\begin{array}{c}\text { Blood TEM } \\
(\boldsymbol{\mu} \mathbf{m})\end{array}$ & $\begin{array}{c}\text { Blood TL } \\
(\boldsymbol{\mu} \mathbf{m})\end{array}$ & $\begin{array}{c}\text { Liver } \\
\text { TDNA } \\
(\text { percent })\end{array}$ & $\begin{array}{c}\text { Liver TEM } \\
(\boldsymbol{\mu} \mathbf{m})\end{array}$ & $\begin{array}{c}\text { Liver TL } \\
(\boldsymbol{\mu} \mathbf{m})\end{array}$ \\
\hline White sucker & WS29 & 9.97 & 3.10 & 26.94 & 12.67 & 4.52 & 20.82 \\
White sucker & WS30 & 8.13 & 2.56 & 29.41 & 21.78 & 10.88 & 31.37 \\
White sucker & WS31 & 10.46 & 3.56 & 30.76 & 14.90 & 6.45 & 29.94 \\
White sucker & WS32 & 5.83 & 1.18 & 18.23 & 13.44 & 6.01 & 27.05 \\
White sucker & WS33 & 6.11 & 1.51 & 23.16 & 11.61 & 4.02 & 24.88 \\
White sucker & WS34 & 6.53 & 1.32 & 16.28 & 9.65 & 5.58 & 55.45 \\
White sucker & WS35 & 4.85 & 1.06 & 20.18 & 12.50 & 4.91 & 21.44 \\
White sucker & WS36 & 6.47 & 1.40 & 17.90 & 12.96 & 5.54 & 26.50 \\
White sucker & WS37 & 6.19 & 1.12 & 17.51 & 9.59 & 3.14 & 19.34 \\
White sucker & WS38 & 7.61 & 1.62 & 18.78 & 9.82 & 3.31 & 18.48 \\
White sucker & WS39 & 8.20 & 1.76 & 18.68 & 16.20 & 5.82 & 22.59 \\
White sucker & WS40 & 5.51 & 1.65 & 26.15 & 9.65 & 5.58 & 55.45 \\
\hline
\end{tabular}


Table 31. H4IIE bioassay-derived 2,3,7,8-tetrachlorodibenzo-p-dioxin equivalents (TCDD-EQ), standard deviation, limit of detection (LOD), and limit of quantitation (LOQ) of composite fish samples collected from the Charles River (August, 2005). Composite samples were based on species and gender. (pg/g, picogram per gram)

\begin{tabular}{lcccccc}
\hline \multicolumn{1}{c}{ Sample } & Gender & Number of fish & LOD & LOQ & $\begin{array}{c}\text { TCDD-EQ } \\
\text { (pg/g wet weight) }\end{array}$ & $\begin{array}{c}\text { Standard } \\
\text { deviation }\end{array}$ \\
\hline Common carp & $\mathrm{F}$ & 10 & 1.2 & 2.5 & 15.6 & $2.5^{1}$ \\
Common carp & $\mathrm{M}$ & 10 & 1.2 & 2.5 & 23.1 & 4.7 \\
Largemouth bass & $\mathrm{F}$ & 8 & 1.2 & 2.5 & 17.0 & 3.6 \\
Largemouth bass & $\mathrm{M}$ & 12 & 1.2 & 2.5 & 29.9 & 3.8 \\
\hline
\end{tabular}

${ }^{1}$ Indicates samples that were extracted in triplicate and assayed in triplicate; all other samples were assayed in duplicate. 
Table 32. Mean hepatic ethoxyresorufin-o-deethylase (EROD) activity rate determined from liver samples collected from common carp (CC) and largemouth bass (LMB) in the Charles River (August, 2005). (pmols/min/mg, picomole per minute per milligram; SD, standard deviation; SE, standard error; CV, coefficient of variation; LOD, limit of detection; LOQ, limit of quantitation)

\begin{tabular}{|c|c|c|c|c|c|c|c|}
\hline Species & Gender & Fish ID & $\begin{array}{c}\text { Mean } \\
\text { EROD } \\
\text { rate }\end{array}$ & SD & CV & LOD1 & $\mathrm{LOQ}^{2}$ \\
\hline Common carp & $\mathrm{F}$ & CC16 & 20.4 & 2.2 & 10.8 & 0.4 & 1.5 \\
\hline Common carp & $\mathrm{F}$ & $\mathrm{CC} 17$ & 1.1 & .1 & 8.5 & .4 & 1.5 \\
\hline Common carp & $\mathrm{F}$ & $\mathrm{CC} 18$ & 42 & 4.1 & 9.9 & .4 & 1.5 \\
\hline Common carp & $\mathrm{F}$ & CC19 & 53.7 & 6.2 & 11.6 & .1 & .8 \\
\hline Common carp & $\mathrm{F}$ & $\mathrm{CC} 20$ & 88.1 & 8.1 & 9.2 & .1 & .8 \\
\hline Common carp & $\mathrm{F}$ & $\mathrm{CC} 3$ & 81.6 & 1.6 & 2 & .4 & 1.5 \\
\hline Common carp & $\mathrm{F}$ & $\mathrm{CC} 4$ & 57.3 & 1.3 & 2.3 & .4 & 1.5 \\
\hline Common carp & $\mathrm{F}$ & CC6 & 6.6 & .9 & 13.5 & .4 & 1.5 \\
\hline Common carp & $\mathrm{F}$ & $\mathrm{CC} 7$ & 2.9 & .6 & 19.3 & .4 & 1.5 \\
\hline Common carp & $\mathrm{F}$ & CC9 & 54.5 & 5.4 & 10 & .4 & 1.5 \\
\hline Common carp & $\mathrm{M}$ & $\mathrm{CC} 1$ & 73.4 & 13.5 & 18.4 & .4 & 1.5 \\
\hline Common carp & M & $\mathrm{CC} 10$ & 25.6 & 4.2 & 16.2 & .4 & 1.5 \\
\hline Common carp & $\mathrm{M}$ & $\mathrm{CC} 11$ & 85.4 & 16 & 18.7 & .4 & 1.5 \\
\hline Common carp & M & $\mathrm{CC} 12$ & 106.5 & 17.8 & 16.7 & .4 & 1.5 \\
\hline Common carp & $\mathrm{M}$ & $\mathrm{CC} 13$ & 108 & 16.4 & 15.2 & .4 & 1.5 \\
\hline Common carp & $\mathrm{M}$ & $\mathrm{CC} 14$ & 1.8 & .3 & 16.8 & .4 & 1.5 \\
\hline Common carp & $\mathrm{M}$ & $\mathrm{CC} 15$ & 47.7 & 9.4 & 19.7 & .4 & 1.5 \\
\hline Common carp & $\mathrm{M}$ & $\mathrm{CC} 2$ & 262.1 & 24.3 & 9.3 & .4 & 1.5 \\
\hline Common carp & $\mathrm{M}$ & $\mathrm{CC} 5$ & 41.4 & 4.2 & 10.2 & .4 & 1.5 \\
\hline Common carp & $\mathrm{M}$ & $\mathrm{CC} 8$ & 28.4 & 2.4 & 8.5 & .4 & 1.5 \\
\hline Largemouth bass & $\mathrm{F}$ & LMB1 & 5 & 1.2 & 23.7 & .1 & .8 \\
\hline Largemouth bass & $\mathrm{F}$ & LMB11 & 6.3 & 1.2 & 19.2 & .1 & .8 \\
\hline Largemouth bass & $\mathrm{F}$ & LMB12 & 94.4 & .9 & .9 & .1 & .8 \\
\hline Largemouth bass & $\mathrm{F}$ & LMB14 & 79.5 & 5.4 & 6.9 & .1 & .8 \\
\hline Largemouth bass & $\mathrm{F}$ & LMB16 & 13.1 & 1.3 & 9.9 & .1 & .8 \\
\hline Largemouth bass & $\mathrm{F}$ & LMB2 & 153 & 14.6 & 9.5 & .1 & .8 \\
\hline Largemouth bass & $\mathrm{F}$ & LMB3 & 8 & 1.1 & 14.1 & .1 & .8 \\
\hline Largemouth bass & $\mathrm{F}$ & LMB7 & 136.5 & 8.8 & 6.5 & .1 & .8 \\
\hline Largemouth bass & M & LMB 19 & 53.9 & 11.6 & 21.6 & 0 & .7 \\
\hline Largemouth bass & M & LMB 20 & 4.1 & .9 & 21.8 & 0 & .7 \\
\hline Largemouth bass & $\mathrm{M}$ & LMB10 & 210.7 & 14.6 & 6.9 & .1 & .8 \\
\hline Largemouth bass & $\mathrm{M}$ & LMB13 & 172.6 & 20.6 & 11.9 & .1 & .8 \\
\hline Largemouth bass & $\mathrm{M}$ & LMB15 & 6.2 & .9 & 14.1 & .1 & .8 \\
\hline Largemouth bass & $\mathrm{M}$ & LMB17 & 166.5 & 29.4 & 17.7 & .1 & .8 \\
\hline Largemouth bass & $\mathrm{M}$ & LMB18 & 162.4 & 14.1 & 8.7 & .1 & .8 \\
\hline Largemouth bass & $\mathrm{M}$ & LMB4 & 223.4 & 28.5 & 12.8 & .1 & .8 \\
\hline Largemouth bass & M & LMB5 & 6.6 & .5 & 7.5 & .1 & .8 \\
\hline Largemouth bass & $\mathrm{M}$ & LMB6 & 84.4 & 12.7 & 15 & .1 & .8 \\
\hline Largemouth bass & $\mathrm{M}$ & LMB8 & 171.1 & 17.1 & 10 & .1 & .8 \\
\hline Largemouth bass & $\mathrm{M}$ & LMB9 & 167.2 & 6.3 & 3.8 & .1 & .8 \\
\hline
\end{tabular}


Table 33. Cytochrome P4501A enzyme activity measured as ethoxyresorufin-o-deethylase (EROD) activity in gill filament tips from white suckers (WS), common carp (CC), and largemouth bass (LMB) collected from the Charles River (August, 2005). Values are presented as mean plus or minus standard deviation (SD) for two replicate wells per fish. Activities are expressed as picomoles (pmols) of resorufin formed/min/filament.

\begin{tabular}{|c|c|c|c|c|}
\hline Species & Gender & Fish ID & $\begin{array}{c}\text { Gill EROD } \\
\text { (pmol/min/filament) }\end{array}$ & SD \\
\hline Common carp & $\mathrm{F}$ & $\mathrm{CC} 16$ & $0.475^{1}$ & 0.041 \\
\hline Common carp & $\mathrm{F}$ & $\mathrm{CC} 17$ & $.405^{1}$ & .102 \\
\hline Common carp & $\mathrm{F}$ & CC18 & $.535^{1}$ & .09 \\
\hline Common carp & $\mathrm{F}$ & $\mathrm{CC} 19$ & .223 & .02 \\
\hline Common carp & $\mathrm{F}$ & $\mathrm{CC} 20$ & $.488^{1}$ & .096 \\
\hline Largemouth bass & $\mathrm{F}$ & LMB11 & .127 & .031 \\
\hline Largemouth bass & $\mathrm{F}$ & LMB12 & .257 & .047 \\
\hline Largemouth bass & $\mathrm{F}$ & LMB13 & .242 & .005 \\
\hline Largemouth bass & $\mathrm{F}$ & LMB14 & .302 & .059 \\
\hline Largemouth bass & $\mathrm{F}$ & LMB15 & .118 & .008 \\
\hline White sucker & $\mathrm{F}$ & WS1 & .175 & .039 \\
\hline White sucker & $\mathrm{F}$ & WS10 & .21 & .006 \\
\hline White sucker & $\mathrm{F}$ & WS11 & .181 & .032 \\
\hline White sucker & $\mathrm{F}$ & WS12 & .006 & .001 \\
\hline White sucker & $\mathrm{F}$ & WS13 & .115 & .035 \\
\hline White sucker & $\mathrm{F}$ & WS2 & .064 & .022 \\
\hline White sucker & $\mathrm{F}$ & WS3 & .101 & .05 \\
\hline White sucker & $\mathrm{F}$ & WS31 & .252 & .052 \\
\hline White sucker & $\mathrm{F}$ & WS32 & .235 & .027 \\
\hline White sucker & $\mathrm{F}$ & WS34 & .293 & .022 \\
\hline White sucker & $\mathrm{F}$ & WS36 & .747 & .034 \\
\hline White sucker & $\mathrm{F}$ & WS37 & .242 & .033 \\
\hline White sucker & $\mathrm{F}$ & WS4 & .261 & .008 \\
\hline White sucker & $\mathrm{F}$ & WS5 & .097 & .012 \\
\hline White sucker & $\mathrm{F}$ & WS6 & .111 & .013 \\
\hline White sucker & $\mathrm{F}$ & WS7 & .45 & .166 \\
\hline White sucker & $\mathrm{F}$ & WS9 & .362 & .07 \\
\hline White sucker & M & WS16 & .316 & .011 \\
\hline White sucker & M & WS20 & .182 & .038 \\
\hline White sucker & $\mathrm{M}$ & WS22 & .609 & .205 \\
\hline White sucker & M & WS23 & .359 & .018 \\
\hline White sucker & M & WS27 & .152 & .008 \\
\hline White sucker & M & WS28 & .303 & .096 \\
\hline White sucker & M & WS33 & .317 & .126 \\
\hline White sucker & M & WS35 & .474 & .007 \\
\hline White sucker & M & WS38 & .074 & .021 \\
\hline White sucker & M & WS39 & .121 & .018 \\
\hline
\end{tabular}

${ }^{T}$ Exceeds highest value in standard curve. 
Table 34. Concentration of vitamin $C$ (ascorbic acid, $A A$ ) and vitamin $E$ (a-tocopherol) as measured in liver tissue from common carp and white suckers collected from the Charles River (August, 2005). Standard deviation from two replicates is presented in parentheses. (TAA, total ascorbic acid; DHA, dehydroascorbic acid; $\mu \mathrm{g} / \mathrm{g}$, micrograms per gram)—Continued

\begin{tabular}{|c|c|c|c|c|c|}
\hline \multirow[t]{2}{*}{ Species } & \multirow[t]{2}{*}{ Fish ID } & \multicolumn{2}{|c|}{$\begin{array}{c}\text { Ascorbic acid }{ }^{1} \\
\text { ( } \mu \mathrm{g} / \mathrm{g} \text { wet weight) }\end{array}$} & \multirow{2}{*}{$\begin{array}{l}\text { Reduced AA } \\
\text { (percent) }\end{array}$} & \multirow{2}{*}{$\begin{array}{c}\alpha-\left.T o c o p h e r o\right|^{2} \\
\text { ( } \mu \mathrm{g} / \mathrm{g} \text { wet weight) }\end{array}$} \\
\hline & & TAA & DHA & & \\
\hline Common carp & $\mathrm{CC} 01$ & $17.33( \pm 3.00)$ & $16.69( \pm 1.79)$ & $4.6( \pm 6.4)$ & $1.25( \pm .05)$ \\
\hline Common carp & $\mathrm{CC} 02$ & $9.75( \pm 3.15)$ & $8.24( \pm 2.10)$ & $14.6( \pm 6.0)$ & $2.04( \pm .03)$ \\
\hline Common carp & $\mathrm{CC} 03$ & $23.98( \pm 3.16)$ & $26.62( \pm .79)$ & .0 & $1.63( \pm .03)$ \\
\hline Common carp & $\mathrm{CC} 04$ & $20.58( \pm 2.81)$ & $18.77( \pm 7.70)$ & $14.1( \pm 20.0)$ & $.69( \pm .14)$ \\
\hline Common carp & $\mathrm{CC} 05$ & $12.98( \pm 1.20)$ & $12.23( \pm 1.00)$ & $8.3( \pm 11.8)$ & $.84( \pm .00)$ \\
\hline Common carp & $\mathrm{CC} 06$ & $19.83( \pm .95)$ & $17.11( \pm .69)$ & $13.5( \pm 7.7)$ & $1.47( \pm .01)$ \\
\hline Common carp & $\mathrm{CC} 07$ & $14.50( \pm .48)$ & $12.16( \pm .44)$ & $16.0( \pm .1)$ & $2.15( \pm .28)$ \\
\hline Common carp & $\mathrm{CC} 08$ & $14.84( \pm 3.27)$ & $13.30( \pm 1.87)$ & $11.9( \pm 3.9)$ & $1.88( \pm .03)$ \\
\hline Common carp & $\mathrm{CC} 09$ & $16.44( \pm 3.00)$ & $13.95( \pm 2.55)$ & $18.5( \pm 22.8)$ & $.87( \pm .00)$ \\
\hline Common carp & $\mathrm{CC} 10$ & $13.93( \pm 2.24)$ & $12.38( \pm 1.19)$ & $12.7( \pm 18.0)$ & $1.18( \pm .30)$ \\
\hline Common carp & $\mathrm{CC} 11$ & $9.30( \pm .42)$ & $9.52( \pm .36)$ & $1.8( \pm 2.5)$ & $3.29( \pm .37)$ \\
\hline Common carp & $\mathrm{CC} 12$ & $17.65( \pm .42)$ & $17.03( \pm .10)$ & $6.3( \pm 3.0)$ & $1.62( \pm .11)$ \\
\hline Common carp & $\mathrm{CC} 13$ & $5.49( \pm .98)$ & $4.97( \pm 2.91)$ & $26.4( \pm 37.2)$ & $1.21( \pm .00)$ \\
\hline Common carp & $\mathrm{CC} 14$ & $26.05( \pm .86)$ & $24.81( \pm .90)$ & $4.7( \pm 6.6)$ & $2.62( \pm .03)$ \\
\hline Common carp & $\mathrm{CC} 15$ & $15.87( \pm .61)$ & $14.62( \pm .67)$ & $7.9( \pm .7)$ & $3.84( \pm .02)$ \\
\hline Common carp & $\mathrm{CC} 16$ & $17.61( \pm 2.62)$ & $13.60( \pm 1.89)$ & $22.5( \pm .1)$ & $.64( \pm .00)$ \\
\hline Common carp & $\mathrm{CC} 17$ & $20.91( \pm 2.31)$ & $18.91( \pm 2.43)$ & $9.6( \pm 1.7)$ & $.70( \pm .18)$ \\
\hline Common carp & $\mathrm{CC} 18$ & $33.04( \pm 3.32)$ & $32.64( \pm 5.22)$ & $4.0( \pm 5.6)$ & $2.99( \pm .07)$ \\
\hline Common carp & CC19 & $26.02( \pm 1.72)$ & $25.57( \pm .75)$ & $2.3( \pm 2.5)$ & $.88( \pm .02)$ \\
\hline Common carp & $\mathrm{CC} 20$ & $43.61( \pm 1.55)$ & $40.96( \pm 2.59)$ & $6.1( \pm 2.6)$ & $2.20( \pm .01)$ \\
\hline White sucker & WS01 & $67.52( \pm 3.31)$ & $61.54( \pm 7.90)$ & $15.7( \pm 6.0)$ & $12.89( \pm .10)$ \\
\hline White sucker & WS02 & $46.34( \pm 2.18)$ & $40.67( \pm 1.75)$ & $12.3( \pm .4)$ & $1.73( \pm .06)$ \\
\hline White sucker & WS03 & $70.78( \pm 3.65)$ & $60.60( \pm .09)$ & $14.3( \pm 4.5)$ & $4.26( \pm .26)$ \\
\hline White sucker & WS04 & $44.24( \pm 2.68)$ & $39.89( \pm .67)$ & $5.4( \pm 7.7)$ & $2.39( \pm .25)$ \\
\hline White sucker & WS05 & $61.00( \pm 3.45)$ & $56.64( \pm 4.81)$ & $7.3( \pm 2.6)$ & $2.56( \pm .04)$ \\
\hline White sucker & WS06 & $16.40( \pm .77)$ & $15.71( \pm .18)$ & $5.7( \pm 1.2)$ & $2.77( \pm .09)$ \\
\hline White sucker & WS07 & $14.85( \pm 1.82)$ & $14.17( \pm .38)$ & $5.3( \pm 7.5)$ & $2.06( \pm .08)$ \\
\hline White sucker & WS08 & $10.87( \pm .24)$ & $10.45( \pm .22)$ & $6.5( \pm .2)$ & $2.83( \pm .23)$ \\
\hline White sucker & WS09 & $29.74( \pm 6.20)$ & $23.52( \pm 7.54)$ & $21.9( \pm 9.0)$ & $3.35( \pm .09)$ \\
\hline White sucker & WS10 & $9.77( \pm .45)$ & $8.83( \pm .36)$ & $9.7( \pm .5)$ & $3.89( \pm .69)$ \\
\hline White sucker & WS11 & $28.49( \pm 1.84)$ & $25.31( \pm .25)$ & $15.8( \pm 8.2)$ & $4.03( \pm .14)$ \\
\hline
\end{tabular}


Table 34. Concentration of vitamin $\mathrm{C}$ (ascorbic acid, AA) and vitamin $\mathrm{E}$ (a-tocopherol) as measured in liver tissue from common carp and white suckers collected from the Charles River (August, 2005). Standard deviation from two replicates is presented in parentheses. (TAA, total ascorbic acid; DHA, dehydroascorbic acid; $\mu \mathrm{g} / \mathrm{g}$, micrograms per gram)—Continued

\begin{tabular}{|c|c|c|c|c|c|}
\hline \multirow[t]{2}{*}{ Species } & \multirow[t]{2}{*}{ Fish ID } & \multicolumn{2}{|c|}{$\begin{array}{c}\text { Ascorbic acid1 } \\
\text { ( } \mu \mathrm{g} / \mathrm{g} \text { wet weight) }\end{array}$} & \multirow{2}{*}{$\begin{array}{c}\text { Reduced AA } \\
\text { (percent) }\end{array}$} & \multirow{2}{*}{$\begin{array}{c}\alpha-\text { Tocopherol2 } \\
\text { ( } \mu \mathrm{g} / \mathrm{g} \text { wet weight) }\end{array}$} \\
\hline & & TAA & DHA & & \\
\hline White sucker & WS12 & $41.38( \pm 6.50)$ & $41.95( \pm 2.44)$ & $7.1( \pm 10.1)$ & $3.91( \pm .11)$ \\
\hline White sucker & WS13 & $34.13( \pm 1.85)$ & $28.86( \pm 6.31)$ & $15.6( \pm 22.0)$ & $4.12( \pm .16)$ \\
\hline White sucker & WS14 & $62.24( \pm 12.86)$ & $55.25( \pm 2.97)$ & $17.1( \pm 24.2)$ & $4.47( \pm .240$ \\
\hline White sucker & WS15 & $55.27( \pm 2.56)$ & $51.42( \pm 3.71)$ & $30.2( \pm 26.4)$ & $5.27( \pm .100$ \\
\hline White sucker & WS16 & $48.72( \pm 2.79)$ & $42.27( \pm 11.99)$ & $41.8( \pm 12.4)$ & $4.81( \pm .05)$ \\
\hline White sucker & WS17 & $36.67( \pm 4.39)$ & $35.78( \pm .78)$ & $7.5( \pm 1.8)$ & $2.28( \pm .040$ \\
\hline White sucker & WS18 & $55.19( \pm 9.15)$ & $52.04( \pm 6.52)$ & $11.5( \pm 16.3)$ & $4.41( \pm .05)$ \\
\hline White sucker & WS19 & $61.05( \pm 8.37)$ & $59.64( \pm 6.38)$ & $2.7( \pm 2.0)$ & $3.10( \pm .34)$ \\
\hline White sucker & WS20 & $68.83( \pm 5.23)$ & $66.63( \pm 7.20)$ & $4.1( \pm 2.0)$ & $7.99( \pm .04)$ \\
\hline White sucker & WS21 & $20.52( \pm .62)$ & $19.64( \pm 1.85)$ & $6.3( \pm 8.8)$ & $5.30( \pm .05)$ \\
\hline White sucker & WS22 & $65.26( \pm 1.41)$ & $60.55( \pm .52)$ & $7.2( \pm 2.9)$ & $13.12( \pm .38)$ \\
\hline White sucker & WS23 & $60.99( \pm 2.95)$ & $47.92( \pm 10.17)$ & $21.0( \pm 21.0)$ & $5.21( \pm .29)$ \\
\hline White sucker & WS24 & $37.93( \pm 1.63)$ & $35.69( \pm .73)$ & $5.86( \pm 2.11)$ & $2.80( \pm .52)$ \\
\hline White sucker & WS25 & $39.50( \pm 4.96)$ & $34.55( \pm 7.22)$ & $12.3( \pm 6.4)$ & $3.53( \pm .06)$ \\
\hline White sucker & WS26 & $60.26( \pm 2.29)$ & $58.94( \pm 4.15)$ & $2.2( \pm 3.2)$ & $2.96( \pm .04)$ \\
\hline White sucker & WS27 & $42.56( \pm 8.94)$ & $29.45( \pm 8.19)$ & $31.2( \pm 4.7)$ & $4.70( \pm .00)$ \\
\hline White sucker & WS28 & $43.36( \pm 1.30)$ & $37.13( \pm .76)$ & $14.4( \pm .1)$ & $5.40( \pm 1.08)$ \\
\hline White sucker & WS29 & $53.26( \pm 3.48)$ & $35.95( \pm .57)$ & $32.3( \pm 5.5)$ & $4.08( \pm .05)$ \\
\hline White sucker & WS30 & $39.81( \pm 3.16)$ & $26.17( \pm 7.70)$ & $34.3( \pm 14.3)$ & $5.88( \pm .21)$ \\
\hline White sucker & WS31 & $77.63( \pm 4.23)$ & $76.59( \pm 1.60)$ & $1.7( \pm 2.4)$ & $7.23( \pm .41)$ \\
\hline White sucker & WS32 & $38.47( \pm 3.33)$ & $30.86( \pm 1.04)$ & $19.0( \pm 9.2)$ & $4.55( \pm .05)$ \\
\hline White sucker & WS33 & $77.17( \pm 1.51)$ & $44.07( \pm .93)$ & $42.9( \pm 2.3)$ & $6.04( \pm .09)$ \\
\hline White sucker & WS34 & $33.79( \pm 6.33)$ & $30.57( \pm 3.88)$ & $9.0( \pm 5.6)$ & $5.14( \pm .14)$ \\
\hline White sucker & WS35 & $74.29( \pm 1.53)$ & $71.72( \pm .31)$ & $3.8( \pm .1)$ & $3.86( \pm .02)$ \\
\hline White sucker & WS36 & $38.95( \pm 1.90)$ & $31.52( \pm 8.07)$ & $19.6( \pm 16.9)$ & $2.15( \pm .04)$ \\
\hline White sucker & WS37 & $50.36( \pm 1.57)$ & $46.52( \pm 15.39)$ & $15.4( \pm 21.7)$ & $15.27( \pm .24)$ \\
\hline White sucker & WS38 & $88.83( \pm 12.76)$ & $83.45( \pm 7.60)$ & $5.7( \pm 5.0)$ & $15.71( \pm .70)$ \\
\hline White sucker & WS39 & $65.27( \pm 1.13)$ & $47.94( \pm 9.19)$ & $26.6( \pm 12.8)$ & $6.39( \pm .04)$ \\
\hline White sucker & WS40 & $86.42( \pm 1.29)$ & $81.19( \pm 1.35)$ & $6.1( \pm .2)$ & $8.34( \pm .19)$ \\
\hline
\end{tabular}


Table 35. Abundance of invertebrates collected from depositional areas from the Charles River on August 25, 2005.

\begin{tabular}{|c|c|c|c|c|c|c|}
\hline Site & Phylum & Class & Order & Family & Taxon & Abundance \\
\hline Site 1 & Annelida & Oligochaeta & Tubificida & Tubificidae & Tubificidae & 161 \\
\hline Site 1 & Arthropoda & Insecta & Diptera & Chironomidae & Cladopelma sp. & 39 \\
\hline Site 1 & Arthropoda & Insecta & Diptera & Chironomidae & Procladius sp. & 22 \\
\hline Site 1 & Arthropoda & Insecta & Diptera & Chironomidae & Chironomini & 13 \\
\hline Site 1 & Nematoda & & & & Nematoda & 10 \\
\hline Site 1 & Arthropoda & Insecta & Diptera & Chironomidae & Polypedilum sp. & 7 \\
\hline Site 1 & Arthropoda & Insecta & Diptera & Chironomidae & Dicrotendipes sp. & 4 \\
\hline Site 1 & Arthropoda & Arachnida & & & Acari & 3 \\
\hline Site 1 & Arthropoda & Insecta & Diptera & Chironomidae & Cryptotendipes sp. & 3 \\
\hline Site 1 & Arthropoda & Insecta & Diptera & Chironomidae & Einfeldia $\mathrm{sp}$. & 3 \\
\hline Site 1 & Mollusca & Bivalvia & Veneroida & Corbiculidae & Corbicula sp. & 3 \\
\hline Site 1 & Annelida & Hirudinea & Rhynchobdellae & Glossiphoniidae & Glossiphoniidae & 1 \\
\hline Site 1 & Annelida & Hirudinea & Rhynchobdellae & Glossiphoniidae & Desserobdella phalera & 1 \\
\hline Site 1 & Annelida & Oligochaeta & Tubificida & Naididae & Naididae & 1 \\
\hline Site 1 & Arthropoda & Insecta & Ephemeroptera & Caenidae & Caenis sp. & 1 \\
\hline Site 1 & Arthropoda & Insecta & Odonata & Corduliidae & Corduliidae & 1 \\
\hline Site 1 & Arthropoda & Insecta & Trichoptera & Hydroptilidae & Hydroptila sp. & 1 \\
\hline Site 1 & Arthropoda & Insecta & Diptera & Chironomidae & Chironominae & 1 \\
\hline Site 1 & Arthropoda & Insecta & Diptera & Chironomidae & Cryptochironomus sp. & 1 \\
\hline Site 1 & Arthropoda & Insecta & Diptera & Chironomidae & Paratendipes sp. & 1 \\
\hline Site 1 & Arthropoda & Insecta & Diptera & Chironomidae & Tribelos sp. & 1 \\
\hline Site 1 & Arthropoda & Malacostraca & Amphipoda & Gammaridae & Gammarus sp. & 1 \\
\hline Site 1 & Mollusca & Bivalvia & & & Bivalvia & 1 \\
\hline Site 1 & Mollusca & Bivalvia & Veneroida & Sphaeriidae & Pisidium sp. & 1 \\
\hline Site 2 & Annelida & Oligochaeta & Tubificida & Tubificidae & Tubificidae & 28 \\
\hline Site 2 & Arthropoda & Arachnida & & & Acari & 5 \\
\hline Site 2 & Nematoda & & & & Nematoda & 5 \\
\hline Site 2 & Arthropoda & Insecta & Diptera & Chironomidae & Cladopelma sp. & 3 \\
\hline Site 2 & Arthropoda & Insecta & Diptera & Chironomidae & Polypedilum sp. & 3 \\
\hline Site 2 & Mollusca & Bivalvia & Veneroida & Corbiculidae & Corbicula sp. & 3 \\
\hline Site 2 & Arthropoda & Insecta & Diptera & Chironomidae & Procladius sp. & 2 \\
\hline Site 2 & Mollusca & Gastropoda & Basommatophora & Planorbidae & Micromenetus dilatatus & 2 \\
\hline
\end{tabular}


Table 35. Abundance of invertebrates collected from depositional areas from the Charles River on August 25, 2005.-Continued

\begin{tabular}{|c|c|c|c|c|c|c|}
\hline Site & Phylum & Class & Order & Family & Taxon & Abundance \\
\hline Site 2 & Mollusca & Bivalvia & Veneroida & Sphaeriidae & Sphaeriidae & 2 \\
\hline Site 2 & Annelida & Hirudinea & & & Hirudinea & 1 \\
\hline Site 2 & Arthropoda & Insecta & Ephemeroptera & Caenidae & Caenis sp. & 1 \\
\hline Site 2 & Arthropoda & Insecta & Coleoptera & Elmidae & Dubiraphia sp. & 1 \\
\hline Site 2 & Arthropoda & Insecta & Diptera & Chironomidae & Chironominae & 1 \\
\hline Site 2 & Arthropoda & Insecta & Diptera & Chironomidae & Cryptochironomus sp. & 1 \\
\hline Site 2 & Arthropoda & Insecta & Diptera & Chironomidae & Dicrotendipes sp. & 1 \\
\hline Site 2 & Mollusca & Gastropoda & Basommatophora & Physidae & Physa sp. & 1 \\
\hline Site 3 & Mollusca & Bivalvia & & & Bivalvia & 107 \\
\hline Site 3 & Arthropoda & Insecta & Diptera & Chironomidae & Tribelos sp. & 38 \\
\hline Site 3 & Mollusca & Bivalvia & Veneroida & Corbiculidae & Corbicula sp. & 29 \\
\hline Site 3 & Annelida & Oligochaeta & Tubificida & Tubificidae & Tubificidae & 16 \\
\hline Site 3 & Arthropoda & Insecta & Diptera & Chironomidae & Polypedilum sp. & 10 \\
\hline Site 3 & Arthropoda & Insecta & Diptera & Chironomidae & Cladopelma sp. & 5 \\
\hline Site 3 & Mollusca & Bivalvia & Veneroida & Sphaeriidae & Pisidium sp. & 4 \\
\hline Site 3 & Arthropoda & Insecta & Diptera & Chironomidae & Chironomus sp. & 3 \\
\hline Site 3 & Arthropoda & Insecta & Diptera & Chironomidae & Procladius sp. & 3 \\
\hline Site 3 & Annelida & Hirudinea & Rhynchobdellae & Glossiphoniidae & Glossiphoniidae & 2 \\
\hline Site 3 & Arthropoda & Insecta & Coleoptera & Elmidae & Stenelmis sp. & 2 \\
\hline Site 3 & Arthropoda & Insecta & Diptera & Chironomidae & Micropsectra/Tanytarsus sp. & 2 \\
\hline Site 3 & Arthropoda & Insecta & Diptera & Chironomidae & Tanytarsus sp. & 2 \\
\hline Site 3 & Mollusca & Gastropoda & Mesogastropoda & Hydrobiidae & Hydrobiidae & 2 \\
\hline Site 3 & Mollusca & Gastropoda & Basommatophora & Planorbidae & Micromenetus dilatatus & 2 \\
\hline Site 3 & Arthropoda & Malacostraca & Amphipoda & & Amphipoda & 1 \\
\hline Site 3 & Arthropoda & Malacostraca & Amphipoda & Gammaridae & Gammarus sp. & 1 \\
\hline Site 3 & Arthropoda & Insecta & Odonata & Corduliidae & Epitheca princeps & 1 \\
\hline Site 3 & Arthropoda & Insecta & Diptera & Chironomidae & Chironomini & 1 \\
\hline Site 3 & Arthropoda & Insecta & Diptera & Chironomidae & Orthocladiinae & 1 \\
\hline Site 3 & Mollusca & Gastropoda & Basommatophora & Ancylidae & Laevapex sp. & 1 \\
\hline Site 3 & Mollusca & Gastropoda & Basommatophora & Planorbidae & Planorbidae & 1 \\
\hline Site 3 & Mollusca & Gastropoda & Basommatophora & Planorbidae & Gyraulus sp. & 1 \\
\hline
\end{tabular}


Table 36. Abundance of invertebrates collected from riffles as part of the National Water-Quality Assessment (NAWQA) protocol from the Charles River during 2002 and 2003 (NAWQA Station 01104615).

\begin{tabular}{|c|c|c|c|c|c|c|}
\hline Collection Date & Phylum & Class & Order & Family & Taxon & Abundance \\
\hline September 17, 2002 & Arthropoda & Insecta & Diptera & Chironomidae & Rheotanytarsus sp. & 3,705 \\
\hline September 17, 2002 & Arthropoda & Insecta & Trichoptera & Hydroptilidae & Leucotrichia pictipes & 3,351 \\
\hline September 17, 2002 & Arthropoda & Insecta & Diptera & Chironomidae & Dicrotendipes sp. & 2,735 \\
\hline September 17, 2002 & Arthropoda & Insecta & Diptera & Chironomidae & Polypedilum sp. & 2,206 \\
\hline September 17, 2002 & Arthropoda & Insecta & Trichoptera & Philopotamidae & Chimarra sp. & 1,678 \\
\hline September 17, 2002 & Annelida & Oligochaeta & Tubificida & Tubificidae & Tubificidae & 1,236 \\
\hline September 17, 2002 & Nematoda & & & & Nematoda & 1,235 \\
\hline September 17, 2002 & Arthropoda & Insecta & Diptera & Chironomidae & Cricotopus sp. & 1,148 \\
\hline September 17, 2002 & Arthropoda & Insecta & Diptera & Chironomidae & Chironominae & 1,146 \\
\hline September 17, 2002 & Arthropoda & Insecta & Diptera & Chironomidae & Cricotopus/Orthocladius sp. & 970 \\
\hline September 17, 2002 & Mollusca & Gastropoda & Basommatophora & Planorbidae & Planorbidae & 794 \\
\hline September 17, 2002 & Arthropoda & Insecta & Trichoptera & Hydropsychidae & Cheumatopsyche sp. & 619 \\
\hline September 17, 2002 & Arthropoda & Malacostraca & Amphipoda & Gammaridae & Gammarus sp. & 618 \\
\hline September 17, 2002 & Annelida & Oligochaeta & Tubificida & Naididae & Naididae & 530 \\
\hline September 17, 2002 & Arthropoda & Insecta & Trichoptera & Hydropsychidae & Hydropsyche depravata group & 442 \\
\hline September 17, 2002 & Arthropoda & Insecta & Trichoptera & Hydropsychidae & Hydropsyche sp. & 442 \\
\hline September 17, 2002 & Mollusca & Bivalvia & Veneroida & Sphaeriidae & Musculium sp. & 442 \\
\hline September 17, 2002 & Arthropoda & Arachnida & & & Acari & 354 \\
\hline September 17, 2002 & Arthropoda & Insecta & Coleoptera & Elmidae & Stenelmis sp. & 354 \\
\hline September 17,2002 & Arthropoda & Insecta & Diptera & Chironomidae & Tvetenia $\mathrm{sp}$ & 354 \\
\hline September 17, 2002 & Arthropoda & Insecta & Diptera & Empididae & Hemerodromia sp. & 353 \\
\hline September 17, 2002 & Arthropoda & Insecta & Diptera & Chironomidae & Orthocladiinae & 353 \\
\hline September 17, 2002 & Mollusca & Gastropoda & Basommatophora & Physidae & Physa sp. & 267 \\
\hline September 17, 2002 & Arthropoda & Insecta & Diptera & Chironomidae & Chironomidae & 265 \\
\hline September 17, 2002 & Arthropoda & Insecta & Diptera & Chironomidae & Cricotopus bicinctus group & 265 \\
\hline September 17, 2002 & Arthropoda & Insecta & Diptera & Chironomidae & Thienemanniella $\mathrm{sp}$. & 265 \\
\hline September 17, 2002 & Mollusca & Gastropoda & Basommatophora & Physidae & Physidae & 265 \\
\hline September 17, 2002 & Mollusca & Gastropoda & Basommatophora & Ancylidae & Ancylidae & 264 \\
\hline September 17, 2002 & Mollusca & Gastropoda & Basommatophora & Ancylidae & Laevapex fuscus & 178 \\
\hline September 17, 2002 & Mollusca & Gastropoda & Mesogastropoda & Hydrobiidae & Hydrobiidae & 177 \\
\hline September 17, 2002 & Annelida & Oligochaeta & Enchytraeida & Enchytraeidae & Enchytraeidae & 176 \\
\hline September 17, 2002 & Arthropoda & Insecta & Diptera & Chironomidae & Cardiocladius sp. & 176 \\
\hline September 17, 2002 & Arthropoda & Insecta & Diptera & Chironomidae & Chironomini & 176 \\
\hline September 17, 2002 & Arthropoda & Insecta & Trichoptera & Hydropsychidae & Hydropsychidae & 176 \\
\hline September 17, 2002 & Arthropoda & Insecta & Ephemeroptera & Baetidae & Baetidae & 89 \\
\hline September 17, 2002 & Arthropoda & Insecta & Trichoptera & Hydroptilidae & Hydroptila sp. & 89 \\
\hline September 17, 2002 & Arthropoda & Insecta & Diptera & Chironomidae & Pentaneura sp. & 89 \\
\hline
\end{tabular}


Table 36. Abundance of invertebrates collected from riffles as part of the National Water-Quality Assessment (NAWQA) protocol from the Charles River during 2002 and 2003 (NAWQA Station 01104615).-Continued

\begin{tabular}{|c|c|c|c|c|c|c|}
\hline Collection Date & Phylum & Class & Order & Family & Taxon & Abundance \\
\hline September 17, 2002 & Arthropoda & Insecta & Diptera & Tipulidae & Antocha sp. & 88 \\
\hline September 17, 2002 & Arthropoda & Insecta & Diptera & Chironomidae & Cricotopus trifascia group & 88 \\
\hline September 17, 2002 & Arthropoda & Insecta & Coleoptera & Elmidae & Elmidae & 88 \\
\hline September 17,2002 & Arthropoda & Insecta & Trichoptera & Hydroptilidae & Hydroptilidae & 88 \\
\hline September 17, 2002 & Arthropoda & Insecta & Trichoptera & Philopotamidae & Philopotamidae & 88 \\
\hline September 17, 2002 & Mollusca & Bivalvia & Veneroida & Sphaeriidae & Sphaeriidae & 88 \\
\hline September 17, 2002 & Annelida & Hirudinea & Arhynchobdellae & Erpobdellidae & Erpobdellidae & 3 \\
\hline September 17, 2002 & Arthropoda & Insecta & Trichoptera & Philopotamidae & Chimarra obscura & 2 \\
\hline September 17,2002 & Arthropoda & Insecta & Hemiptera & Veliidae & Rhagovelia obesa & 2 \\
\hline September 17, 2002 & Arthropoda & Malacostraca & Isopoda & Asellidae & Caecidotea sp. & 2 \\
\hline September 17, 2002 & Arthropoda & Insecta & Diptera & Chironomidae & Ablabesmyia sp. & 1 \\
\hline September 17, 2002 & Arthropoda & Insecta & Ephemeroptera & Baetidae & Baetis flavistriga & 1 \\
\hline September 17, 2002 & Arthropoda & Insecta & Ephemeroptera & Baetidae & Baetis intercalaris & 1 \\
\hline September 17, 2002 & Arthropoda & Insecta & Ephemeroptera & Baetidae & Baetis sp. & 1 \\
\hline September 17, 2002 & Arthropoda & Insecta & Hemiptera & Belostomatidae & Belostoma lutarium & 1 \\
\hline September 17, 2002 & Arthropoda & Insecta & Diptera & & Brachycera & 1 \\
\hline September 17, 2002 & Arthropoda & Insecta & Odonata & Coenagrionidae & Coenagrionidae & 1 \\
\hline September 17, 2002 & Arthropoda & Insecta & Odonata & Corduliidae & Corduliidae & 1 \\
\hline September 17, 2002 & Arthropoda & Insecta & Ephemeroptera & Baetidae & Heterocloeon sp. & 1 \\
\hline September 17, 2002 & Arthropoda & Insecta & Diptera & Tipulidae & Limonia sp. & 1 \\
\hline September 17, 2002 & Arthropoda & Insecta & Hemiptera & Mesoveliidae & Mesovelia sp. & 1 \\
\hline September 17,2002 & Arthropoda & Insecta & Hemiptera & Gerridae & Metrobates hesperius & 1 \\
\hline September 17,2002 & Arthropoda & Insecta & Coleoptera & Elmidae & Microcylloepus sp. & 1 \\
\hline September 17, 2002 & Arthropoda & Insecta & Diptera & Chironomidae & Parachironomus sp. & 1 \\
\hline September 17, 2002 & Arthropoda & Insecta & Diptera & Chironomidae & Phaenopsectra/Tribelos sp. & 1 \\
\hline September 17, 2002 & Arthropoda & Insecta & Hemiptera & Nepidae & Ranatra fusca & 1 \\
\hline September 17, 2002 & Arthropoda & Insecta & Coleoptera & Scirtidae & Scirtidae & 1 \\
\hline September 17,2002 & Arthropoda & Insecta & Diptera & Simuliidae & Simuliidae & 1 \\
\hline September 17,2002 & Arthropoda & Insecta & Diptera & Simuliidae & Simulium sp. & 1 \\
\hline September 17, 2002 & Arthropoda & Insecta & Ephemeroptera & Heptageniidae & Stenacron sp. & 1 \\
\hline September 17, 2002 & Arthropoda & Insecta & Ephemeroptera & Leptohyphidae & Tricorythodes sp. & 1 \\
\hline September 17, 2002 & Arthropoda & Malacostraca & Amphipoda & Crangonyctidae & Crangonyx sp. & 1 \\
\hline September 17, 2002 & Mollusca & Gastropoda & Basommatophora & Planorbidae & Helisoma anceps & 1 \\
\hline September 17,2002 & Platyhelminthes & Turbellaria & & & Turbellaria & 1 \\
\hline August 20, 2003 & Arthropoda & Insecta & Trichoptera & Philopotamidae & Chimarra sp. & 3,996 \\
\hline August 20, 2003 & Arthropoda & Insecta & Trichoptera & Hydropsychidae & Hydropsyche depravata group & 1,050 \\
\hline August 20, 2003 & Arthropoda & Insecta & Trichoptera & Hydropsychidae & Hydropsychidae & 1,048 \\
\hline
\end{tabular}


Table 36. Abundance of invertebrates collected from riffles as part of the National Water-Quality Assessment (NAWQA) protocol from the Charles River during 2002 and 2003 (NAWQA Station 01104615).-Continued

\begin{tabular}{|c|c|c|c|c|c|c|}
\hline Collection Date & Phylum & Class & Order & Family & Taxon & Abundance \\
\hline August 20,2003 & Arthropoda & Insecta & Diptera & Chironomidae & Rheotanytarsus sp. & 969 \\
\hline August 20, 2003 & Arthropoda & Insecta & Trichoptera & Hydropsychidae & Hydropsyche sp. & 848 \\
\hline August 20, 2003 & Arthropoda & Insecta & Trichoptera & Hydroptilidae & Leucotrichia pictipes & 847 \\
\hline August 20, 2003 & Arthropoda & Insecta & Trichoptera & Hydroptilidae & Hydroptila sp. & 686 \\
\hline August 20, 2003 & Arthropoda & Insecta & Trichoptera & Hydropsychidae & Cheumatopsyche sp. & 565 \\
\hline August 20,2003 & Arthropoda & Insecta & Ephemeroptera & Baetidae & Baetidae & 403 \\
\hline August 20, 2003 & Arthropoda & Malacostraca & Amphipoda & Gammaridae & Gammarus sp. & 364 \\
\hline August 20, 2003 & Annelida & Oligochaeta & Tubificida & Naididae & Naididae & 324 \\
\hline August 20, 2003 & Arthropoda & Insecta & Trichoptera & Hydroptilidae & Hydroptilidae & 323 \\
\hline August 20, 2003 & Arthropoda & Insecta & Diptera & Chironomidae & Tvetenia sp. & 283 \\
\hline August 20, 2003 & Mollusca & Bivalvia & Veneroida & Sphaeriidae & Musculium sp. & 283 \\
\hline August 20, 2003 & Arthropoda & Insecta & Diptera & Chironomidae & Polypedilum sp. & 243 \\
\hline August 20, 2003 & Arthropoda & Insecta & Coleoptera & Elmidae & Stenelmis sp. & 243 \\
\hline August 20, 2003 & Mollusca & Gastropoda & Mesogastropoda & Hydrobiidae & Hydrobiidae & 203 \\
\hline August 20, 2003 & Arthropoda & Arachnida & & & Acari & 202 \\
\hline August 20,2003 & Arthropoda & Insecta & Diptera & Tipulidae & Antocha sp. & 202 \\
\hline August 20, 2003 & Arthropoda & Insecta & Diptera & Empididae & Hemerodromia sp. & 162 \\
\hline August 20,2003 & Annelida & Oligochaeta & Tubificida & Tubificidae & Tubificidae & 161 \\
\hline August 20, 2003 & Mollusca & Bivalvia & Veneroida & Sphaeriidae & Sphaeriidae & 161 \\
\hline August 20, 2003 & Mollusca & Gastropoda & Basommatophora & Ancylidae & Laevapex sp. & 161 \\
\hline August 20, 2003 & Arthropoda & Insecta & Trichoptera & Philopotamidae & Chimarra obscura & 122 \\
\hline August 20, 2003 & Arthropoda & Insecta & Diptera & Chironomidae & Cricotopus/Orthocladius sp. & 122 \\
\hline August 20, 2003 & Arthropoda & Insecta & Diptera & Simuliidae & Simuliidae & 122 \\
\hline August 20, 2003 & Nematoda & & & & Nematoda & 122 \\
\hline August 20, 2003 & Platyhelminthes & Turbellaria & & & Turbellaria & 122 \\
\hline August 20, 2003 & Arthropoda & Insecta & Diptera & Chironomidae & Cardiocladius sp. & 121 \\
\hline August 20, 2003 & Arthropoda & Insecta & Diptera & Chironomidae & Dicrotendipes sp. & 121 \\
\hline August 20,2003 & Arthropoda & Insecta & Diptera & Chironomidae & Orthocladiinae & 121 \\
\hline August 20, 2003 & Arthropoda & Insecta & Diptera & Simuliidae & Simulium sp. & 83 \\
\hline August 20,2003 & Arthropoda & Insecta & Diptera & Chironomidae & Chironomidae & 81 \\
\hline August 20, 2003 & Annelida & Hirudinea & Arhynchobdellae & Erpobdellidae & Erpobdellidae & 43 \\
\hline August 20, 2003 & Arthropoda & Insecta & Coleoptera & Elmidae & Macronychus glabratus & 42 \\
\hline August 20, 2003 & Mollusca & Bivalvia & Veneroida & Sphaeriidae & Pisidium sp. & 41 \\
\hline August 20, 2003 & Annelida & Oligochaeta & Enchytraeida & Enchytraeidae & Enchytraeidae & 40 \\
\hline August 20,2003 & Arthropoda & Insecta & Diptera & Empididae & Hemerodromiinae & 40 \\
\hline August 20, 2003 & Arthropoda & Insecta & Diptera & Chironomidae & Pentaneura sp. & 40 \\
\hline August 20, 2003 & Arthropoda & Insecta & Trichoptera & Glossosomatidae & Protoptila sp. & 40 \\
\hline
\end{tabular}


Table 36. Abundance of invertebrates collected from riffles as part of the National Water-Quality Assessment (NAWQA) protocol from the Charles River during 2002 and 2003 (NAWQA Station 01104615).-Continued

\begin{tabular}{|c|c|c|c|c|c|c|}
\hline Collection Date & Phylum & Class & Order & Family & Taxon & Abundance \\
\hline August 20,2003 & Mollusca & Gastropoda & Basommatophora & Planorbidae & Planorbidae & 40 \\
\hline August 20,2003 & Nemertea & Enopla & Hoplonemertea & Tetrastemmatidae & Prostoma sp. & 40 \\
\hline August 20, 2003 & Annelida & Hirudinea & Rhynchobdellae & Glossiphoniidae & Glossiphoniidae & 3 \\
\hline August 20, 2003 & Arthropoda & Insecta & Coleoptera & Elmidae & Ancyronyx variegata & 2 \\
\hline August 20, 2003 & Annelida & Hirudinea & Rhynchobdellae & Glossiphoniidae & Helobdella stagnalis & 1 \\
\hline August 20, 2003 & Annelida & Oligochaeta & Lumbriculida & Lumbriculidae & Lumbriculidae & 1 \\
\hline August 20, 2003 & Annelida & Oligochaeta & & & Megadrile & 1 \\
\hline August 20, 2003 & Arthropoda & Insecta & Diptera & Chironomidae & Ablabesmyia sp. & 1 \\
\hline August 20, 2003 & Arthropoda & Insecta & Ephemeroptera & Baetidae & Baetis flavistriga & 1 \\
\hline August 20, 2003 & Arthropoda & Insecta & Ephemeroptera & Baetidae & Baetis intercalaris & 1 \\
\hline August 20, 2003 & Arthropoda & Insecta & Ephemeroptera & Baetidae & Baetis sp. & 1 \\
\hline August 20, 2003 & Arthropoda & Insecta & Diptera & Chironomidae & Cricotopus sp. & 1 \\
\hline August 20, 2003 & Arthropoda & Insecta & Diptera & Chironomidae & Cryptochironomus sp. & 1 \\
\hline August 20,2003 & Arthropoda & Insecta & Coleoptera & Elmidae & Dubiraphia sp. & 1 \\
\hline August 20, 2003 & Arthropoda & Insecta & Coleoptera & Elmidae & Elmidae & 1 \\
\hline August 20, 2003 & Arthropoda & Insecta & Diptera & Chironomidae & Glyptotendipes sp. & 1 \\
\hline August 20, 2003 & Arthropoda & Insecta & Ephemeroptera & Baetidae & Heterocloeon $\mathrm{sp}$. & 1 \\
\hline August 20, 2003 & Arthropoda & Insecta & Trichoptera & Hydropsychidae & Hydropsyche betteni & 1 \\
\hline August 20,2003 & Arthropoda & Insecta & Ephemeroptera & Heptageniidae & Maccaffertium modestum & 1 \\
\hline August 20, 2003 & Arthropoda & Insecta & Coleoptera & Elmidae & Microcylloepus pusillus & 1 \\
\hline August 20, 2003 & Arthropoda & Insecta & Diptera & Chironomidae & Phaenopsectra sp. & 1 \\
\hline August 20, 2003 & Arthropoda & Insecta & Ephemeroptera & Heptageniidae & Stenacron sp. & 1 \\
\hline August 20, 2003 & Arthropoda & Insecta & Diptera & Chironomidae & Tanytarsus sp. & 1 \\
\hline August 20, 2003 & Arthropoda & Insecta & Diptera & Chironomidae & Tribelos sp. & 1 \\
\hline August 20, 2003 & Arthropoda & Malacostraca & Isopoda & Asellidae & Caecidotea sp. & 1 \\
\hline August 20, 2003 & Arthropoda & Malacostraca & Amphipoda & Crangonyctidae & Crangonyx sp. & 1 \\
\hline August 20, 2003 & Arthropoda & Malacostraca & Decapoda & Cambaridae & Orconectes sp. & 1 \\
\hline August 20, 2003 & Mollusca & Bivalvia & Veneroida & Sphaeriidae & Sphaerium sp. & 1 \\
\hline August 20, 2003 & Mollusca & Gastropoda & Basommatophora & Planorbidae & Helisoma anceps & 1 \\
\hline August 20, 2003 & Mollusca & Gastropoda & Basommatophora & Ancylidae & Laevapex fuscus & 1 \\
\hline August 20,2003 & Mollusca & Gastropoda & Basommatophora & Planorbidae & Micromenetus sp. & 1 \\
\hline August 20, 2003 & Mollusca & Gastropoda & Basommatophora & Physidae & Physa sp. & 1 \\
\hline
\end{tabular}


Figure 37. Abundance of fish collected as part of the National Water-Quality Assessment (NAWQA) protocol from the Charles River during 2002 and 2003 (NAWQA Station \#01095220).

\begin{tabular}{|c|c|c|c|c|}
\hline Collection Date & Family & Scientific name & Common name & Abundance \\
\hline September 18, 2002 & Cyprinidae & Cyprinus carpio & Common carp & 65 \\
\hline September 18, 2002 & Percidae & Perca flavescens & Yellow perch & 24 \\
\hline September 18, 2002 & Catostomidae & Catostomus commersonii & White sucker & 22 \\
\hline September 18, 2002 & Centrarchidae & Lepomis macrochirus & Bluegill & 20 \\
\hline September 18, 2002 & Centrarchidae & Lepomis auritus & Redbreast sunfish & 19 \\
\hline September 18,2002 & Centrarchidae & Micropterus salmoides & Largemouth bass & 18 \\
\hline September 18, 2002 & Anguillidae & Anguilla rostrata & American eel & 11 \\
\hline September 18, 2002 & Centrarchidae & Micropterus dolomieu & Smallmouth bass & 10 \\
\hline September 18, 2002 & Centrarchidae & Lepomis gibbosus & Pumpkinseed & 8 \\
\hline September 18,2002 & Clupeidae & Alosa sapidissima & American shad & 6 \\
\hline September 18, 2002 & Cyprinidae & Carassius auratus & Goldfish & 3 \\
\hline September 18, 2002 & Centrarchidae & Lepomis cyanellus & Green sunfish & 2 \\
\hline September 16, 2003 & Centrarchidae & Lepomis macrochirus & Bluegill & 127 \\
\hline September 16, 2003 & Catostomidae & Catostomus commersonii & White sucker & 64 \\
\hline September 16, 2003 & Moronidae & Morone americana & White perch & 57 \\
\hline September 16, 2003 & Clupeidae & Alosa sapidissima & American shad & 30 \\
\hline September 16, 2003 & Centrarchidae & Lepomis gibbosus & Pumpkinseed & 26 \\
\hline September 16, 2003 & Percidae & Perca flavescens & Yellow perch & 26 \\
\hline September 16, 2003 & Cyprinidae & Cyprinus carpio & Common carp & 21 \\
\hline September 16, 2003 & Centrarchidae & Lepomis auritus & Redbreast sunfish & 21 \\
\hline September 16, 2003 & Anguillidae & Anguilla rostrata & American eel & 11 \\
\hline September 16, 2003 & Centrarchidae & Micropterus salmoides & Largemouth bass & 7 \\
\hline September 16, 2003 & Cyprinidae & Notemigonus crysoleucas & Golden shiner & 3 \\
\hline September 16, 2003 & Centrarchidae & Micropterus dolomieu & Smallmouth bass & 2 \\
\hline August 31, 2004 & Cyprinidae & Notropis hudsonius & Spottail shiner & 57 \\
\hline August 31, 2004 & Catostomidae & Catostomus commersonii & White sucker & 35 \\
\hline August 31, 2004 & Percidae & Perca flavescens & Yellow perch & 28 \\
\hline August 31, 2004 & Cyprinidae & Cyprinus carpio & Common carp & 25 \\
\hline August 31, 2004 & Centrarchidae & Lepomis auritus & Redbreast sunfish & 25 \\
\hline August 31, 2004 & Anguillidae & Anguilla rostrata & American eel & 18 \\
\hline August 31, 2004 & Centrarchidae & Micropterus dolomieu & Smallmouth bass & 14 \\
\hline August 31, 2004 & Centrarchidae & Micropterus salmoides & Largemouth bass & 12 \\
\hline August 31, 2004 & Clupeidae & Alosa aestivalis & Blueback herring & 11 \\
\hline August 31, 2004 & Centrarchidae & Lepomis macrochirus & Bluegill & 11 \\
\hline August 31, 2004 & Moronidae & Morone americana & White perch & 11 \\
\hline August 31, 2004 & Centrarchidae & Lepomis gibbosus & Pumpkinseed & 9 \\
\hline August 31, 2004 & Centrarchidae & Pomoxis nigromaculatus & Black crappie & 4 \\
\hline August 31, 2004 & Moronidae & Morone saxatilis & Striped bass & 2 \\
\hline August 31, 2004 & Cyprinidae & Notemigonus crysoleucas & Golden shiner & 2 \\
\hline August 31, 2004 & Ictaluridae & Ameiurus natalis & Yellow bullhead & 1 \\
\hline August 31, 2004 & Ictaluridae & Ameiurus nebulosus & Brown bullhead & 1 \\
\hline August 23, 2005 & Centrarchidae & Lepomis auritus & Redbreast sunfish & 54 \\
\hline August 23, 2005 & Anguillidae & Anguilla rostrata & American eel & 38 \\
\hline August 23, 2005 & Centrarchidae & Lepomis macrochirus & Bluegill & 37 \\
\hline August 23, 2005 & Centrarchidae & Lepomis gibbosus & Pumpkinseed & 22 \\
\hline August 23, 2005 & Centrarchidae & Micropterus dolomieu & Smallmouth bass & 21 \\
\hline August 23, 2005 & Centrarchidae & Micropterus salmoides & Largemouth bass & 12 \\
\hline August 23, 2005 & Percidae & Perca flavescens & Yellow perch & 9 \\
\hline August 23, 2005 & Catostomidae & Catostomus commersonii & White sucker & 7 \\
\hline August 23, 2005 & Cyprinidae & Cyprinus carpio & Common carp & 3 \\
\hline
\end{tabular}




\section{Acknowledgments}

Many individuals provided invaluable field and laboratory expertise for a timely completion of the collections and analyses. This includes John Coll (Lamar Fish Health Center, Lamar, Penn), Carla Wieser, Tim Gross, Janet Scarborough associated with the USGS Florida Integrated Science Center at Gainesville, Fla., Tom May, Mike Walther, Bill Brumbaugh, Dave Alvarez, Walt Cranor, Stephanie Perkins, Vickie Schroeder, Randy Clark, Carl Orazio, John Meadows, George Tegerdine, Robert Gale, Kathy Echols, Chris Ingersoll, and Don Tillitt associated with the USGS Columbia Environmental Research Center, ) Adria Elskus from the USGS Field Reseach Station located at the University of Maine, Tom Leiker from the National Water Quality Laboratory, Lakewood, Colo., Kim Campo, Dave Armstrong, Megan Chaisson, Sara Flanegan and Jonathan Kennon Karen Beaulieu associated with the former USGS Northeast Area Offices, Jim Coles and John Meier with the U.S. Environmental Protection Agency Region 1 (New England), ; U.S. Fish and Wildlife Service (Concord, N.H.; Ken Munney, Drew Major); USGS S.C. Fish and Wildlife Cooperative Research Unit at Clemson University (Jeff Isley); Ohio State University (Konrad Dabrowski), University of Florida (Nancy Denslow, Kevin Kroll). We would also like to acknowledge and thank Tim Frick (WRD Conn.) and Deborah Iwanowicz (Leetown Science Center) for graciously reviewing the report. Numerous scientists with the National Water-Quality Assessment (NAWQA) Program were consulted and provided valuable insights.

\section{References Cited}

Adams, S.M., 1990, Status and use of biological indicators for evaluating the effects of stress on fish, in Adams, S.M., ed, Biological indicators of stress in fish: American Fisheries Society Symposium 8, p. 1-8.

Adams, S.M., Brown, A.M., Goede, R.W., 1993, A quantitative health assessment index for rapid evaluation of fish condition in the field: Transactions of the American Fisheries Society, v. 122, p. 63-73.

Alvarez, D.A., Cranor, W.L., Perkins, S.D., Schroeder, V.L., and Clark, R.C.,2006, Use of passive samplers for monitoring organic contaminants in the Charles River: U.S. Geological Survey, Columbia Environmental Research Center, Columbia, Mo., Final Report, 45 p.

Ankley, G.T., Benoit, D.A., Balogh, J.C., Reynoldson, T.B., Day, K.E., 1994, Evaluation of potential confounding factors in sediment toxicity tests with three freshwater benthic invertebrates: Enviornmental Toxicology and Chemistry, v. 13, no. 4, p. 627-635.

American Society for Testing and Materials E729 - 96, 2007, Standard guide for conducting acute toxicity tests on test materials with fishes, macroinvertebrates, and amphibians: West Conshohocken, Penn., American Society for Testing and Materials.

Baumann, P.C., Smith, I.R., and Metcalfe, C.D., 1996, Linkages between chemical contaminants and tumors in benthic Great Lakes fishes: Journal of Great Lakes Research, v. 22, no. 2, p.131-152.

Baumann, P.C., 1998, Epizootics of cancer in fish associated with genotoxins in sediment and water-Reviews in mutation research: Mutation Research, v. 411, p. 227-233.

Baumann, P.C., Harshbarger, J.C., and Hartman, K.J., 1990, Relations of liver tumors to age structure of brown bullhead populations from two Lake Erie tributaries: Science of the Total Environment, v. 94, p. 71-88. 
Bevans, H.E., Goodbred, S.L., Miesner, J.F., Watkins, S.A., Gross, T.S., Denslow, N.D., and Schoeb, T., 1996, Synthetic organic compounds and carp endocrinology and histology in Las Vegas wash and Las Vegas Callville Bays of Lake Mead, Nevada, 1992 and 1995: U.S. Geological Survey, Water Resources Investigations Report 96-4266, 12 p.

Blazer, V.S., 2002, Histopathological assessment of gonadal tissue in wild fishes: Fish Physiology and Biochemistry, v. 26, p. 85-106.

Blazer, V.S., Facey, D.E., Fournie, J.W., Courtney, L.A., and Summers, J.K.,1994, Macrophage aggregates as indicators of environmental stress, in Stolen, J.S., Fletcher, T.C., Modulators of fish immune responses, Volume 1-Models for enviromental toxicology, biomarkers, immunostimulators: Fair Haven, N.J., SOS publications, p. 169-186.

Blazer, V.S., Dethloff, G.M., Wright, B., 2002, Fish health indicators: U.S. Geological Survey, Biological Resources Division, Information and Technology Report, USGS/BRD/ITR - 20020004, p. 89-134.

Blazer, V.S., Fournie, J.W., Weeks-Perkins, B.A., 1997, Macrophage aggregates-Biomarker for immune function in fishes?, in Dwyer, F.J., Doane, T.R., Hinman, M.L., eds., Environmental toxicology and risk assessment-Modeling and risk assessment, Volume 6: Philadelphia, Penn., American Society for Testing and Materials, ASTM STP 1317, p. 360-375

Birke, S.R., and Tillitt, D.E., 2000, Determination of 2,3,7,8-tetraclorodizenzo-p-diozin equivalents (TCDD-EQ) with H4IIE bioassay on fish tissue samples collected from the Columbia and Lower Rio Grande river basins as part of the 1997 Biomonitoring of Environmental Status and Trends (BEST) Program: U.S. Geological Survey, Biochemistry and Physiology Branch Report.

Brown, S.B., Adams, B.A., Cyr, D.G., and Eales, J.G., 2004, Contaminant effects on the teleost fish thyroid: Environmental Toxicology and Chemistry, v. 23, p. 1680-1701.

Brumbaugh, W.G., Arms, J.W., 1996, Quality control considerations for the determination of acidvolatile sulfide and simultaneously extracted metals in sediments: Environmental Toxicology and Chemistry, v. 15, no. 3, p. 282-285.

Burton, G.A., Jr., Norberg-King, T.J., Benoit, D.A., Ankley, G.T., Winger, P.V., Kubitz, J., Lazorchak, J.M., Smith, M.E., Call, D. 1 J., Ingersoll, C.G., Greer, E., Dwyer, F.J., Day, K.E., Kennedy, P., and Stinson, M., 1996, Interlaboratory study of precision-Hyalella azteca and Chironomus tentans freshwater sediment toxicity assays: Environmental Toxicology and Chemistry, v. 15, no. 8, p. 1335-1343.

Campana, S.E., and Neilson, J.D., 1985, Microstructure of fish otoliths: Canadian Journal of Fisheries and Aquatic Sciences, v. 42, p. 1014-1032.

Coll, J.A., 2006, Fish health analyses for Charles River study: U.S. Fish and Wildlife Service, Lamar, Penn., Lamar Fish Health Center Case 05-280.

Collier, T.K., Stein, J.E., Sanborn, H.R., Hom, T., Meyers, M.S., and Varanasi, U., 1992, Field studies of reproductive success and bioindicators of maternal contaminant exposure in English sole (Parophyrys vetuslus): Science of the Total Environment, v. 116, p. 169-185.

Contaminant Biology Program, 2002, From laboratory to landscape: U.S. Geological Survey, Biologial Resoources Dicipline, Program Review, 123 p.

Cuffney, T.F., Gurtz, M.E., and Meador, M.R., 1993, Methods for collecting benthic invertebrate samples as part of the national water-quality assessment program: U.S. Geological Survey, OpenFile Report 93-406, 66 p.

Dabrowksi, K., and Ciereszko, A., 2001, Ascorbic acid and reproduction in fish-Endocrine regulation and gamete quality: Aquaculture Research, v. 32, p. 623-638. 
Dabrowski, K., Hinterleitner, S., 1989, Simultaneous analysis of ascorbic acid, dehydroascorbic acid and ascorbic sulphate in biological materials: Analyst, v. 114, p. 83-87.

Denslow, N.D., Chow, M., Chow, M.C., Folmar, L.C., Monomelli, S., Heppell, S.A., and Sullivan, C.V., 1996, Development of antibodies to teleost vitellogenins-Potential biomarkers for environmental estrogens, in Bengston, D.A., and Henshel, D.S., eds., Environmental toxicology and risk assessment: American Society for Testing and Materials, v. ASTM STP13065, p. 23-36.

Denslow, N.D., Chow, M.C., Kroll, K.J., and Green, L., 1996, Vitellogenin as a biomarker of exposure for estrogen or estrogen mimics: Ecotoxicology, v. 8, p. 385-398.

Denslow, N.D., Chow, M., Chow, M.C., Bonomelli, S., Folmar, L.C., Heppell, S.A., and Sullivan, C.V., 1997, Development of biomarkers for environmental contaminants affecting fish, in Rolland, R M., Gilbertson, M., and Peterson, R.E., eds., Chemically induced alterations in functional development and reproduction of fishes: Pensacola, Fla., Society of Enviornmental Toxicology and Chemistry (SETAC) Press, p. 73-86.

Denslow, N.D., Chow, M.C., Groll, K.F., and, Green, L., 1999, Vitellogenin as a biomarker for estrogen or estrogen mimics: Ecotoxicology, v. 8, p. 385-398.

Dermott, R.M., 1991, Deformities in larval Procladius spp. and dominant Chironomini from the St. Clair River: Hydrobiologia, v. 219, p. 171-175.

Dickman, M., Brindle, I., and Benson, M., 1992, Evidence of teratogens in sediments of the Niagara River Watershed as reflected by chironomid (Diptera: Chironomidae) deformities: Journal of Great Lakes Research, v. 18, p. 467-480.

Eisler, R, 1987. Polyaromatic aromatic hydrocarbon hazards to fish, wildlife, and invertebrates: a synoptic review. U.S. Fish and Wildlife Service Biological Report 85 (1:11).

Fitzpatrick, F.A., Waite, I.R., Arconte, P.J., Meador, M. R., Maupin, M.A., and Gurtz, M.E., 1998, Revised methods for characterizing stream habitat in the National Water-Quality (NAWQA) program: U.S. Geological Survey, Water Resources Investigations Report 98-4052, 67 p.

Fishman, M.J., Raese, J.W., Gerlitz, C.N., and Husband, R.A., 1994, U.S. Geological Survey approved inorganic and organic methods for the analysis of water and fluvial sediment, 1954-94: U.S. Geological Survey Open-File Report 94-351, 55 p.

Fournie, J.W., Summers, J.K., and Weisberg, S.B., 1996, Prevalence of gross pathological abnormalities in estuarine fishes: Transaction of the American Fisheries Society, v. 125, p. 581-590.

Friorentino, J.F., Kennedy, L.E., and Weinstein, M.J., 2000, Charles River watershed 1997/1998 water quality assessment report: Boston, Mass., Massachusetts Department of Environmental Protection, report no. 72-AC-3.

Furlong, E.T., Vaught, D.G., Merten, L.M., Foreman, W.T., and Gates, P.M., 1996, Methods of analysis by the U.S. Geological Survey National Water Quality Laboratory-Determination of semivolatile organic compounds in bottom sediment by solvent extraction, gel permeation chromatographic fractionation, and capillary-column gas chromatography/mass spectrometry: U.S. Geological Survey Open-File Report 95-719, 67p.

Goodbred, S.L., Gilliom, R.J., Gross, T.S., Denslow, N.D., Bryant, W.B., and Schoeb T.R., 1997, Reconnaissance of 17 $\beta$-estradiol, 11-ketotestosterone, vitellogenin, and gonad histopathology in common carp of United States streams - Potential for contaminant induced endocrine disruption: U.S. Geological Survey, Open File Report 96-627, 47 p.

Grady A.W., McLaughlin R.M., Caldwell C.W., Schmitt C.J., Stalling D.L. 1992, Flow cytometry, morphometry and histopathology as biomarkers of benzo $(a)$ pyrene exposure in brown bullheads (Ameiurus nebulosus): Journal of Applied Toxicology, v. 12, p. 165-77. 
Grau, E. G., 1987, Thyroid hormones, in Pang, P.K., and Schreibman, M.P., eds., Vertebrate endocrinology_Fundamentals and biomedical implications: San Diego, California, Academic Press, v. 2, p. 85-102.

Gross, T.S., Arnold, B.S., Sepulevda, M.S.,and McDonald, K., 2003, Endocrine disrupting chemicals and endocrine active agents, in Hoffman, D.J., Rattner, B.A., Burton, G.A., Jr., and Cairns, J., Jr, eds., Handbook of ecotoxicology: Washington, D.C., Lewis Publishers, p. 10331098.

Hinck, J.E., Schmitt, C.J., Bartish, T.M., Denslow, N.D., Blazer, V.S., Anderson, P.J., Coyle, J.J., Dethloff, G.M., and Tillitt, D.E., 2004, Biomonitoring of Environmental Status and Trends (BEST) Program-Environmental contaminants and their effects on fish in the Columbia River Basin: U.S. Geological Survey, Scientific Investigations Report 2004-5154, 125 p.

Hinton, D.E., Teh, S.J., Okihiro, M.S., Cooke, J.B., and Parker, L.M., 1992, Phenotypically altered hepatocyte populations in diethylnitrosamine-induced medaka liver carcinogenesis-Resistance, growth, and fate: Marine Environmental Research, v. 34, p. 1-5.

Hinton, D.E., 1993, Toxicologic histopathology of fishes-A systemic approach and overview, in Couch, J.A., and Fournie, J.W., eds., Pathobiology of marine and estuarine organisms: Boca Raton, Fla., CRC Press, p. 177-215.

Hoffman, D.J., Rattner, B.A., Burton, G.A., Jr., and Cairns, J., Jr., (eds.), 2003, Handbook of ecotoxicology: Boca Raton, Fla., Lewis Publishers, 1260 p.

Hoffman, G.L., 1996, Methods of analysis by the U.S. Geological Survey National Water Quality Laboratory - Preparation procedure for aquatic biological material determined for trace metals:

U.S. Geological Survey, Open-File Report 96-362, 42 p.

Ingersoll, C.G., 1995, Sediment tests, in Rand, G.M., ed., Fundamentals of aquatic toxicology: Washington, D.C., Taylor and Francis, p. 231-256.

Ingersoll, C.G., Wang, N., Hayward, J.M.R., Jones, J.R., Jones, S.B. and Ireland, D.S., 2005, A field assessment of long-term laboratory sediment toxicity tests with the amphipod Hyalella azteca: Environmental Toxicology and Chemistry, v. 24, no. 11, p. 2853-2870.

Ingersoll, C.G., MacDonald, D.D., Brumbaugh, W.G., Johnson, B.T., Kemble, N.E., Kunz, J.L., May, T.W., Wang, N., Smith, J., Sparks, D., and Ireland, D.S., 2002, Toxicity assessment of sediments from the Grand Calumet River in Indiana Harbor Canal in northwestern Indiana, USA: Archives of Environmental Contamination and Toxicology, v. 43, no. 2, p. 156-167.

Johnson, B.T., and Long, E.R., 1998, Rapid toxicity assessment of sediments from estuarine ecosystems - A new tandem in vitro testing approach: Environmental Toxicology and Chemistry, v. 17, p. 1099-1106.

Jonsson, E.M., Brandt, I., and Brunstrom, B., 2002, Gill filament-based EROD assay for monitoring waterborne dioxin-like pollutants in fish: Environmental Science \& Technology, v. 36, no. 15. p. 3340-3344.

Jonsson, E.M., Abrahamson, A., Brunstrom, B., Brandt, I., 2006, Cytochrome P4501A induction in rainbow trout gills and liver following exposure to waterborne indigo, benzo[a]pyrene and 3,3',4,4',5-pentachlorobiphenyl: Aquatic Toxicology, v. 79, p. 226-232.

Kaiser, K.L.E., and Palabrica, V.S., 1991, Photobacterium phosphoreum toxicity data index: Water Quality Research Journal of Canada, v. 26, no. 33, p. 361-431.

Keith, L.H., 1991, Environmental sampling and analysis - A practical guide: Boca Raton, Fla., CRC Press, $160 \mathrm{p}$.

Keith, L.H., Crummet, W., Deegan, J., Jr., Libby, R.A., Taylor, J.K., and Wentler, G., 1983, Principles of environmental analysis: Analytical Chemistry, v. 55, p. 2210-2218. 
Kennedy, S.W., and Jones, S.P., 1994, Simultaneous measurement of cytochrome P4501A catalytic activity and total protein concentration with a fluorescence plate reader: Analytical Biochemistry, v. 222, no. 1, p. 217-223.

Kime, D.E., and Nash, J.P., 1999, Gamete viability as an indicator of reproductive endocrine disruption in fish: The Science of the Total Environment, v. 233, p. 123-129.

Krahn, M.M., Myers, M.S., Burrows, D.G., and Malins, D.C., 1984, Determination of metabolites of xenobiotics in bile of fish from polluted waterways: Xenobiotica, v. 14, p. 633-646.

Kumar, S., and Pant, S.C., 1988, Comparative sublethal ovarian pathology of some pesticides in the telost, Punitius conchonius Hamilton: Bulletin of Environmental Contamination and Toxicology, v. 41, p. 227-232.

Leiker, T.J., Madsen, J.E., Deacon, J.R., and Foreman, W.T., 1995, Methods of analysis by the U.S. Geological Survey National Water Quality Laboratory-Determination of chlorinated pesticides in aquatic tissue by capillary-column gas chromatography with electron-capture detection: U.S. Geological Survey Open-File Report 94-710, 42 p.

Leiker, T.J., Abney, S.R.,Goodbred, S.L., and Rosen, M.R., 2008, Identification of methyl triclosan and halogenated analogues in mail carp (Cyprinus carpio) from Las Vegas Bay and semipermeable membrane devices from Las Vegas Wash, Nevada: Science of the Total Environment, $13 \mathrm{p}$.

Lowry, O.H., Rosbrough, N.J., Farr, A.L., and Randall, R.J., 1951: Journal of Biological Chemistry, v. 193, p. 265.

May, T.W., Walther, M., and Brumbaugh, W.G., 2006, Determination of metals in pore water, sediment and fish from the Charles River, Massachusetts: U.S. Geological Survey, Columbia Environmental Research Center, Final Report CERC-8335-FY06-32-02, 15 p.

Meier, J.R., Chang, L.W., Daniel, F.B., Franson, S.E., and Wernsing, P., 2001, Genetic damage indicators in fish exposed to varying stream conditions in an agricultural watershed:

Environmental Molecular Mutagenesis, v. 37 (supplement 32), p. 52.

Moulton, S.R., Kennen, J.G., Goldstein, R.M., and Hambrook, J.A., 2002, Revised protocols for sampling algal, invertebrate, and fish communities as part of the National Waster Quality (NAWQA) Program: U.S. Geological Survey Open File Report 02-150, 87 p. (Also available at http://pubs.usgs.gov/of/2002/ofr-02-150/.)

Moulton, S.R., Carter, J.L., Grotheer, S.A., Cuffney, T.F., and Short, T.M., 2000, Methods of analysis by the U.S. Geological Survey, National Water Quality Laboratory-Processing, taxonomy, and quality control of benthic macroinvertebrate samples: U.S. Geological Survey Open-File Report 00-212, 49 .

Neilson, M.A., Painter, D.S., Warren, G., Hites, R.A., Basu, I., Wesehof, D.V.C., Whitte, D.M., Christic, G., Barbeiru, R., Tuchman, M., Johannsson, D.E., Nalepa, T.F., Edsall, T.A., Fleischer, G., Bronte, C., Smith, S.B., and Baumann, P.C., 2003, Ecological monitoring for assessing the state of the nearshore and open waters of the Great Lakes: Environmental Monitoring and Assessment, v. 88, no. 1-3, p. 103-117.

National Research Council, 2002, Opportunities to improve the U.S. Geological Survey National Water-Quality Assessment Program: Washington, D.C., National Academy Press, 238 p.

National Research Council, 1995, A review of the biomonitoring of environmental status and trends program - The draft detailed plan: Committee to Review the Department of the Interior's Biomonitoring of Environmental Status and Trends Program Washington, D.C., National Academy Press, 74 p. 
Olson, M.C., Iverson, J.L., Furlong, E.T., and Schroeder, M.P., 2004, Methods of analysis by the U.S. Geological Survey National Water Quality Laboratory-Determination of polycyclic aromatic hydrocarbon compounds in sediment by gas chromatography /mass spectrometry: U.S. Geological Survey Water-Resources Investigations Report 03-4318, 45 p.

Orazio, C., Echols, K., Meadows, J., Feltz, K., Tegerdine, G., Peterman, P., 2006, Organic contaminants in fish and sediments collected from the Charles River in 2005: U.S. Geological Survey, Columbia Environmental Research Center, Final Report, 15 p. [plus tables].

Patino, R., Goodbred, S.L., Draugelis-Dale, R., Barry, C.E., Foott, J.S., Wainscott, M.R., Gross, T.S., and Covay, K.J., 2003, Morpometric and histological parameters of gonadal development in adult common carp from contaminated and reference sites in Lake Mead, Nevada: Journal of Aquatic Animal Health, v. 15, p. 55-68.

Popper, A.N., and Lu, Z., 2000, Structure-function relationships in fish otolith organs: Fisheries Research, v. 46, p.15-25.

Pohl, R.J, and Fouts, J.R., 2007, A rapid method for assaying the metabolism of 7-ethoxyresorufin by microsomal subcellular fractions: Analytical Biochemistry, v. 107, no. 1, p. 150-155.

Rastogi, A., and Kulshrestha, S.K, 1990, Effect of sublethal does of three pesticides on the ovary of a carp minnow Tasbora daniconius: Bulletin of Environmental Contaminantion and Toxicology, v. 45, p. $742-747$.

Roe, J.H., and Kuether, C.A., 1943, The determination of ascorbic acid in whole blood and urine through the 2,4-dinitrophenylhydrazine derivative of dehydroascorbic acid: Journal of Biological Chemistry, v. 147, p. 399-407.

Schmitt, C.J., Blazer, V.S., Dethloff, G.M., Tillet, D.E., Gross, T.S., Bryant, W.L., Jr., DeWeese, V., Smith, S.B., Goede, R.W., Bartish, T.M., and Kubiak, T.J., 1999, Biomonitoring of Environmental Status and Trends (BEST) Program-Field procedures for assessing the exposure of fish to environmental contaminants: Columbia, Mo., U.S. Geological Survey, Biological Resources Division, Information and Technology Report, USGS/BRD-1999-000-7, 68 p.

Schmitt, C.J., Zajicek, J.L., May, T.W., and Cowman, D.F., 1999, Organochlorine residues and elemental contaminants in U.S. freshwater fish, 1976-1986-National Contaminant Biomonitoring Program: Review of Environmental Contamination and Toxicology, v. 162, p. 43-104.

Schmitt, C.J., and Dethloff, G.M., 2000, Biomonitoring of Environmental Status and Trends (BEST) Program-Selected methods for monitoring chemical contaminants and their effects in aquatic ecosystems: Columbia, Mo., U.S. Geological Survey, Biological Resources Division, Information and Technology Report, USGS/BRD-2000-0005, 81 p.

Schmitt, C.J., ed., 2002, Biomonitoring of Environmental Status and Trends (BEST) ProgramEnvironmental contaminants and their effects on fish in the Mississippi River Basin: U.S. Geological Survey, Biological Science Report 2002-0004.

Schmitt, C., Dethloff, G., Hinck, J., Bartish, T., Blazer, V., Coyle, J., Denslow, N., Tillitt, D., 2004, Biomonitoring of Environmental Status and Trends (BEST) Program-Environmental contaminants and their effects on fish in the Rio Grande Basin: U.S. Geological Survey, Biological Resources Division, Scientific Investigations Report 2004-5108, 117 p.

Sepulveda, M.S., Quinn, P.B., Denslow, N.D., Holm, S.E., and Gross, T.S., 2003, Effects of pulp and paper mill effluents on reproductive success of largemouth bass: Environmental Toxicology and Chemistry, v. 22, p. 205-213. 
Shelton, L.R., 1994, Field guide for collecting and processing stream-water samples for the National Water-Quality Assessment Program: U.S. Geological Survey, Open-File Report 94455, $42 \mathrm{p}$.

Singh, N.P., McCoy, M.T., Tice, R.R., and Schneider, E.L., 1988, A simple technique for quantitation of low levels of DNA damage in individual cells: Experimental Cell Research, v. 175 , no. 1, p. 184-191.

Skougstad, M.W., Fishman, M.J., Friedman, L.C., Erdmann, D.E., and Duncan, S.S., 1979, Methods for determination of inorganic substances in water and fluvial sediments: U.S. Geological Survey, Techniques of Water Resources Investigations, book 5, chap. A1, 626 p.

Smith, S.B., Donahue, A.P., Lipkin, R.J., Blazer, V.S., Schmitt, C.J., and Goede, R.W., 2002, Illustrated field guide for assessing external and internal anomalies in fish: U.S. Geological Survey, Information and Technology Report 2002-0007, 46 p.

Smith, S.B., Gross, T.S., and Denslow, N.D., 2002, Endocrine biomarkers in largemouth bass (Micropterus salmoides) related to polychlorinated biphenyls (PCBs) in Woods Pond, Housatonic River, Massachusetts: U.S. Geological Survey, Florida Integrated Science Center, Report 001-2002, 18 p.

Toft, G., Edward, T.M., Baatrup, E., and Gillette, L.J., Jr., 2003, Disturbed sexual characteristics in male mosquitofish (Gambusia holbrooki) from a lake contaminated with endocrine disruptors: Environmental Health Perspectives, v. 11, p. 695-701.

U.S. Environmental Protection Agency, 2000, National guidance-Guidance for assessing chemical contaminant data for use in fish advisories - Volume 1-Sampling and analysis (3d ed.): Washington D.C., U.S. Environmental Protection Agency 823-B-00-007, 485 p.

U.S. Environmental Protection Agency, 2001, EPA Superfund Explanation of Significant Differences: US Army Material Technology Laboratory (USARMY) EPA ID: MA0213820939, Watertown MA. U. S. Environmental Protection Agency Region 1 EPA/ESD/R01-01/014/2001, $39 \mathrm{p}$.

Van Metre, P.C., Mahler, B.J., and Furlong, E.T., 2000, Urban sprawl leaves its PAH signature: Environmental Science and Technology, v. 34, p. 4064-4070.

Waddell, B., and May, T., 1995, Selenium concentrations in the razorback sucker (Xyrauchen texanus) - Substitution of non-lethal muscle plugs for muscle tissue in contaminant assessment: Archives of Environmental Contamination and Toxicology, v. 28, p. 321-326.

Weiskel, P.K., Barlow, L.K., and Smieskel, T.W., 2005, Water resources and the urban environment, Lower Charles River watershed, Massachusetts, 1630-2005: U.S. Geological Survey Circular 1280, 46 p.

White, A., Fletcher, T.C., Secombes, C.J., and Houlihan, D.F., 1993, The effect of different dietary levels of vitamins $\mathrm{C}$ and $\mathrm{E}$ on their tissue levels in the Atlantic salmon, Salmo salar L., in Kaushik, S.J., and Luquet, P., eds., Fish nutrition in practice: Paris, Les Colloques, p. 203-207.

Whyte, J.J., Jung, R.E., Schmitt, C.J., and Tillitt, D.E., 2000, Ethoxyresorufin-O-deethylase (EROD) activity in fish as a biomarker of chemical exposure: Critical Reviews in Toxicology, $v$. 30, p. 347-570.

Yang, X., Peterson, D.S., Baumann, P.C., and Lin, E.L.C., 2003, Fish biliary PAH metabolites estimated by fixed-wavelength fluorescence as an indicator of environmental exposure and effects: Journal of Great Lakes Research, v. 29, no. 1, p. 116-123.

Zhou T., John-Alder, H.B., and Weis, J.S., 2000, Endocrine disruption-Thyroid dysfunction in mummichogs from a polluted habitat: Marine Environmental Research, v. 50, p. 393-397. 
Publishing support provided by:

Denver Publishing Service Center

For more information concerning this publication, contact: Center Director, USGS Fort Collins Science Center 2150 Centre Ave., Bldg. C

Fort Collins, CO 80526-8118

(970) 226-9398

Or visit the Fort Collins Science Center Web site at: http://www.fort.usgs.gov/ 